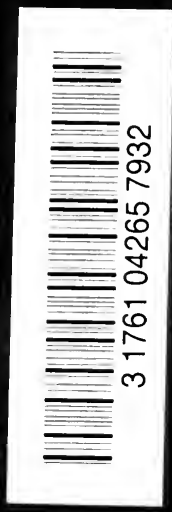


Digitized by the Internet Archive in 2007 with funding from Microsoft Corporation 


ASPECTS OF ALGERIA 




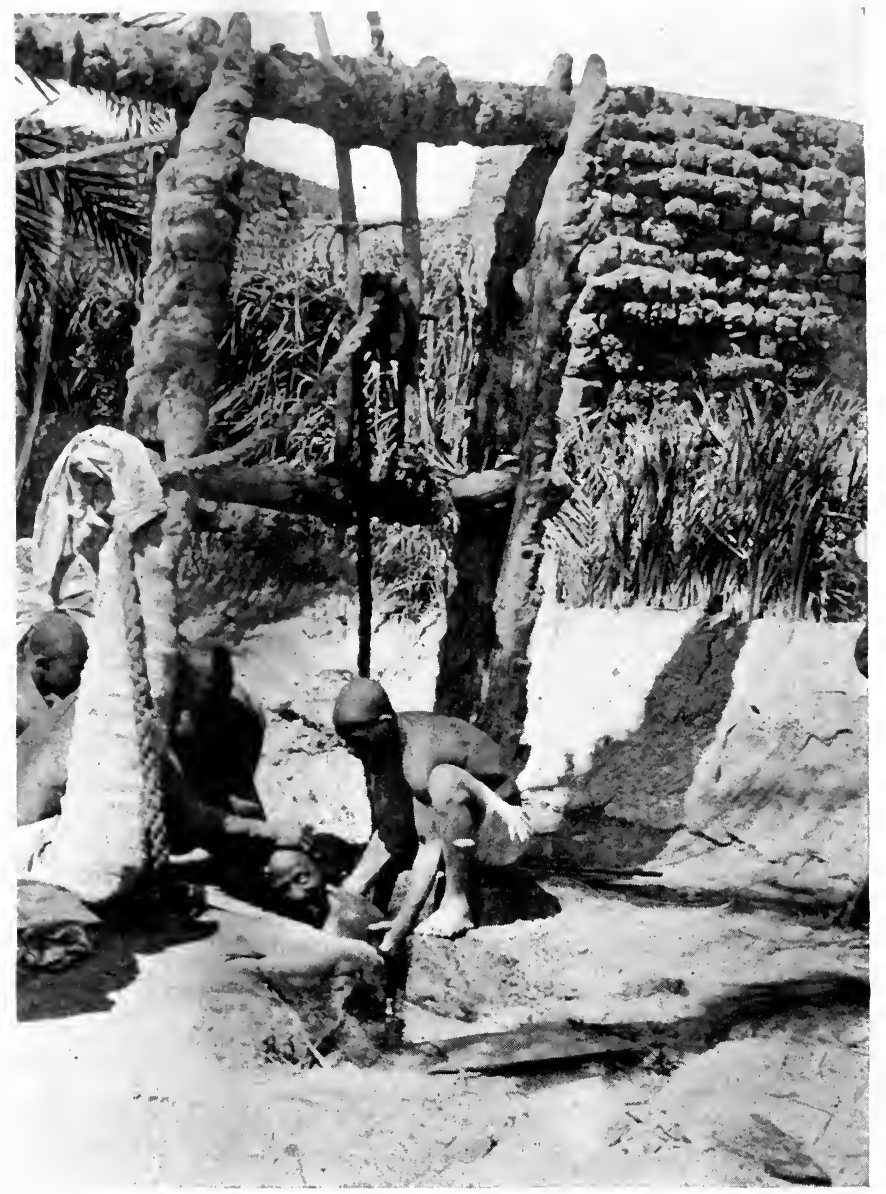

A NATIVE WELL 


\section{HAf \\ $D .49132$}

ASPECTS of ALGERIA

HISTORICAL-POLITICAL-COLONIAL

BY

ROY DEVEREUX

AUthor of "SIDElights on south africa," etc.

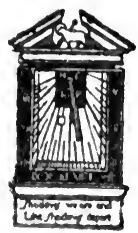

WITH NUMEROUS ILLUSTRATIONS $A N D$ A $M A P$

$$
\frac{170365}{10.4 .22}
$$

LONDON: J. M. DENT \& SONS, LTD. NEW YORK: E. P. DUTTON \& CO. 1912 
All rights reserved 
TO MY FRIEND

B. RENNIE

OPTIMIST 



\section{FOREWORD}

IN order to avoid charging the text I append to this volume a list of books which includes the majority of those I have consulted and whose authority I have quoted in the course of this brief analysis of historical and contemporary conditions in Algeria. To several of their authors-in particular Professor A. Le Chatelier of the Collège de France and Syed Ameer Ali-I owe cordial thanks for much valuable advice. With regard to the spelling of Arabic words all names and geographical terms are copied from the statistics and maps compiled by the Government-General of Algeria, to whose officials, both civil and military, my gratitude is also due for invariable courtesy and assistance. 



\section{CONTENTS}

CHAP. PAGE

I IMPRESSIONS OF EL-DJEZAIR . . . . . I

II KABYLIA OF THE BERBERS • . . . 22

III THE ROMAN PROVINCE OF MAURETANIA . . 4I

7 IV MSLAM PAST AND FUTURE . • . . 59 -

v VTHE ARAB IN ART AND SCIENCE • • . 83

VI THE TURK IN BARBARY . $\quad$. $\quad . \quad$. $\quad .98$

VII THE FRENCH CONQUEST OF ALGERIA . . II5 -

VIII THE MOSLEM SUBJECTS OF FRANCE • • I37

2. IX $\sqrt{T H E}$ COLONIZATION OF ALGERIA . . . I59-

$x$ on the high plateaux . . . . $\quad{ }^{8} 83$

3. Xi The industrial Development of algeria . 200

XII DATE CULTURE IN THE SAHARA . • . 2 I9

, XIII THE EVOLUTION OF THE ALgerians • . 242

XIV ALGERIA'S EASTERN NEIGHBOUR • . . 262

6 XV WHE FUTURE OF ALGERIA . . . . 281 -

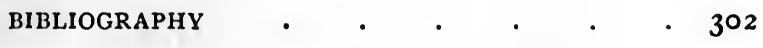

INDEX • • . $\quad . \quad+\quad . \quad$. 305

ix 



\section{LIST OF ILLUSTRATIONS}

A NATIVE WELL $\quad \cdot \quad \cdot \quad \cdot \quad \cdot \quad$ Frontispiece

To face page

THE PORT OF ALGIERS .

THE CEMETERY OF SIDI-EL-KHEBIR • • • . . I 7

A Kabyle village • • • • • • • • 32

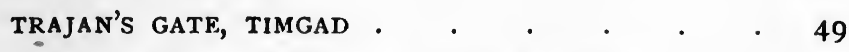

THE TAKING OF SMALA-BY HORACE VERNET . . 64

THE OASIS AT BISKRA . . . . . . . 80

THE MOSQUE OF SIDI-BOU-MEDINE • • • • $\quad$ • 97

THE EMPEROR'S FORT (I830) • . . . . II2

THE RELEASE OF ABD-EL-KADER • • • • . I 29

CAPTAIN MOHAMMED BEN-DRISS, EX-AGHA OF TOUG-

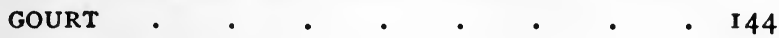

AN ARAB CARAVAN . . . . . . . I6o

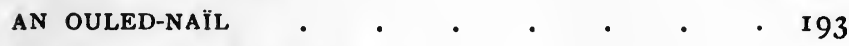

THE GORGE OF EL-KANTARA . . . . . 208

SAND DUNES IN THE SAHARA • . . . . 257

TUNIS FROM THE DAR-EL-BEY • . . . . 272

THE COLOSSEUM OF EL-DJEM . . . . . $\quad . \quad 288$

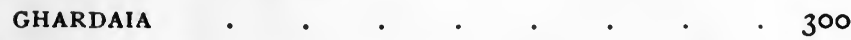

MAP OF ALGERIA AND TUNISIA * * * $\quad$ • 304 




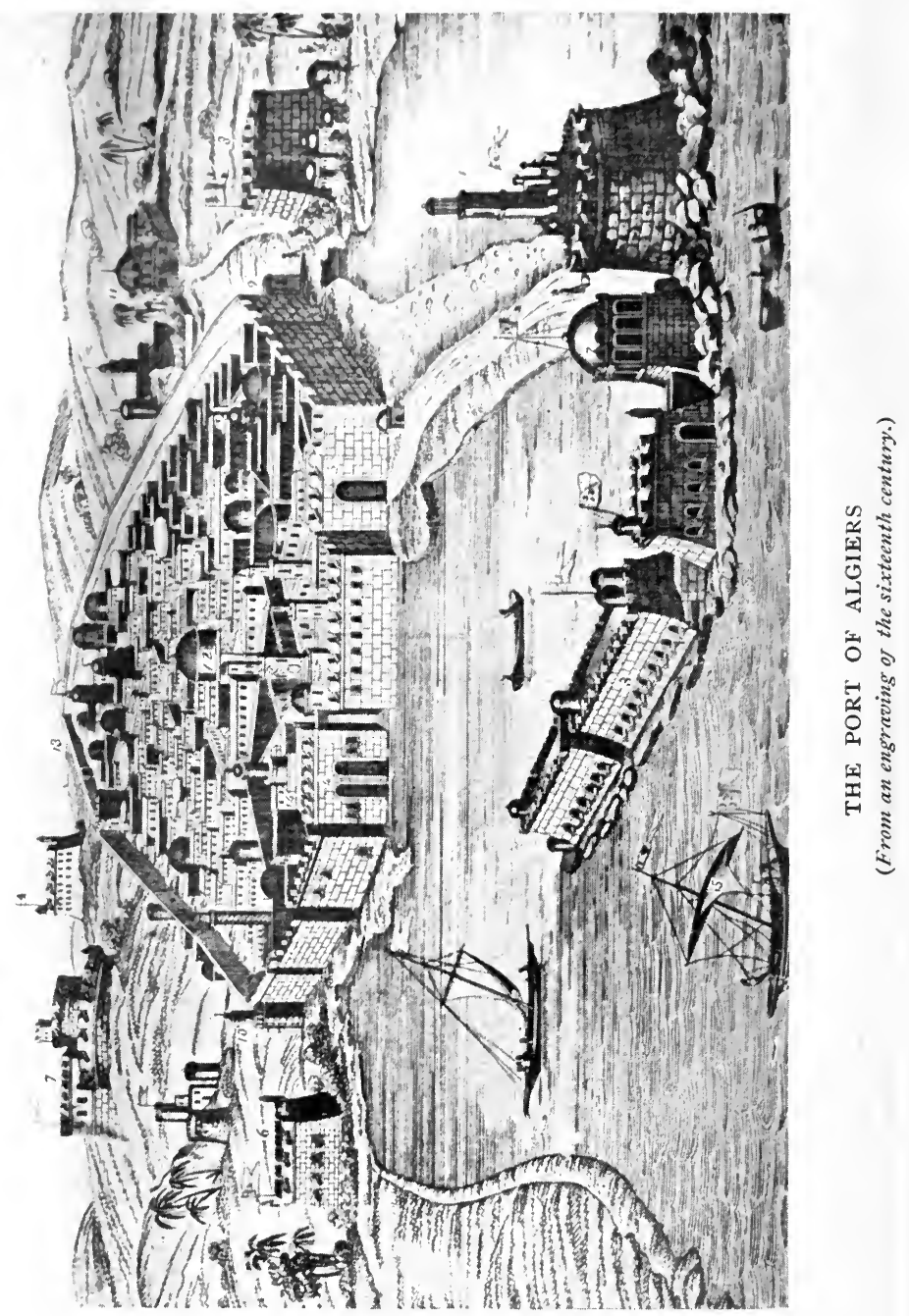




\title{
ASPECTS OF ALGERIA
}

\author{
CHAPTER I \\ IMPRESSIONS OF EL-DJEZAIR
}

I HAVE often wondered within the shelter of curtains drawn like a vizor over the face of winter whether the poet who sang the resemblance between parting and death was a simple sentimentalist, or a philosopher with the gift of irony added to the gift of expression. For it is a damnable error, even if you have an organ worthy of the task, to sing Partir c'est mourir un peu to a literal generation. A journey, however urgent, is a mere alternative, an escape from the tyranny of quotidian things and the devil of misplaced energy. At best it is to find one's way into a new moral and physical atmosphere; at worst it indicates a malady of the soul, whose cure is symbolized by return. But to scale "Death's haggard hills" is a solution, not only of untimely frosts and vintages, but of all nostalgias as of all satieties. It is the solution.

Which reflection, with divers qualifications, decided my departure. Change, "the longing to 
assume the citizenship of an unknown world," to use Amiel's phrase, seemed my most immediate need. That was also what the gentle Genevese scholar cared for most-to enrich himself " with some fresh form of existence, to feel it from within, to link myself to it, and to reproduce it sympathetically." 'Thus he describes his ambition, and better words could not be found to express that hunger for a new inspiration, for new understanding wherewith to achieve "that synthesis to which everything-streets, houses, landscape, accent, dialect, physiognomies, history and habitcontribute their share." The fact that he seldom quitted the professorial chair in no ways convicts Amiel of insincerity. His imagination engraved a universe on the sensitive plate of his mind. One element alone was lacking-the biting acid of experience. What matter in a world where the realization of our ideals is the stuff of sorrow!

All one's environment does, indeed, conspire to arrest those who would fain companion the last swallow. The solicitude of love makes a drama of each departure, grudging, it may be, the indelible impression one will bring back-an impression not to be expelled from the memory as dust is cleansed from retracing feet. Of course the prodigal who returns is not as he who sped from the too familiar door; but had he never crossed its threshold, time would equally have done 
its work upon his ego. Stability has naught to do with that phenomenon of equilibrium which we call human life. Nevertheless, upon the soul of the traveller time writes its comments large and deep, and the road he follows is usually too long to drag thereover the baggage of regret. So that it permits him to become another among others; so that it leads to the new and the beautifulwhich is the eternally new-the wayfarer is content, peradventure to the point of seeking to burn his boats.

Like the master-painters of old, the traveller is sometimes wiser than he knows. He is capable of unconsciously emulating Saul the son of Kish, "who started out to find his father's asses, and instead thereof found a kingdom." My own steps seem to be invariably turned by some latent impulse, southward and eastward, in the direction of those lands where I can watch the flowers yield each day more of their colour and perfume to the sun, where strange dreams haunt siestas that promise their repose to the purple vigil of the night. Some intuition must have suggested Algeria to my hesitating will, benumbed by the ice of an English February. There at least warm respite might be found from the morbid energy of the North. In the ways of Allah I hoped to attain the spring, and to catch some echo of the voice of the Prophet with an obbligato of singing birds.

B 2 
So before many days passed I had begun my Odyssey on the deck of a good German ship rounding in a dead calm the southern angle of Spain. Eastward at last we pressed through an unctuous sea which, like the sky, reflected the opalescence of the sunset. Far away on the horizon one could just detect the undulation of land coming imperceptibly nearer on the port side. "Africa!" shouted a brave sailor who loved the outward voyage. "Africa!" replied my jaded spirit and shivering body, as I strained my eyes to discern the faint violet edge of that continent whose heart is fire.

But as the destruction of beauty is ever synchronous with the progress of civilization, it was inevitable that the melody of El-Djezair should expire in the diminuendo of Alger. 'This attenuation of four magic syllables into two flaccid ones is characteristic of all that has been wrought in half a century's span upon this sweet southern margin of the Mediterranean Sea. And all because Hussein-Dey, last of his line, struck the French Consul with a fan. So runs the legend, accepted still as fact. It served equally well the purpose of the Dey's impatient creditors and of the European Powers, weary of an inveterate piracy which shocked the awakening commercial sense of the nineteenth century. El-Djezair was, indeed, the stronghold of the accursed corsair, who, in spite 


\section{IMPRESSIONS OF EL-DJEZAIR}

of tribute, continued to pillage Christian ships and to enslave Christian passengers whenever he got the chance, oblivious of the fact that piracy had become an anachronism.

The price of peace, which was no peace, rankled. Christian blood, still visible to the imaginative globe-trotter on the colossal walls of the Darse, cried for vengeance. So, fan or no fan, the optimism of Hussein-Dey struck the deathblow of El-Djezair and all the lawless plunder, and the white, shrouded beauty for which it stood. El-Djezair! Oh, the music of it in an Arab mouth - a song with a dagger-thrust at the end! El-Djezair, who scoffed at Charles $\mathrm{V}$ and Louis XIV; El-Djezair, who imprisoned Cervantes, is as dead as the sea-wolves of Barbary. Here and there a pallid remnant of her past survives in French Alger-a library that was sometime a palace, a group of twisted tamarisks on the shore where once a garden bloomed-and on the western edge of the town a cluster of huddled houses tinted like caramels, known to the tourists as the Arab quarter of the Kasbah. More than Bobadilla's mountain in the Sierra Nevada, the Arab quarter merits to be called el ultimo sospiro del Moro, for any day some Gallic iconoclast may build a boulevard across the Rue des Sarrasins. Already the modern town surrounds it on three sides like the waves of an encroaching sea, and one 
wonders how long it will continue to offer to the aggressor the passive resistance of its inertia.

Quite suddenly, as you turn out of the French highway, you find yourself in the Orient, almost before you miss the familiar sounds of the Western life you have left. One begins the ascent of these winding streets, which are not so much streets as stairs, with the sensation of invading another world. Houses edge these tortuous ways, which seem to possess none of the characteristics of human habitations. Their windows are mere cracks in the surface of their walls, inaccessible and ironbarred as is the low door hidden in a shadowy corner. Sometimes the houses touch each other, forming a vault over the ladder-like street; sometimes a dark passage, suggesting the entrance to a dungeon, opens into a sort of bazaar, where objects of which one can scarcely guess the utility are exposed for sale. Merchants who look like mummies crouch in the midst of their motley wares. Strings of pepper-pods and dried fish hang beside silken robes and embroidered sandals; sacks of green henna, destined to dye slender fingers and feet, are flanked by fragments of red flesh and chaplets of orange blossoms. And the whole street exhales the hot, indescribable odour of the Eastthe scent of organic matter in decay mingled with the aroma of many spices and the perfume of many flowers, 
Figures, whose outline is as indefinable as the architecture of their houses, flutter round this curious merchandise, which responds to most of their limited needs. Great eyes, ringed with kohl, pierce the white veils that cover the women as a calyx its flower. They barter for the objects of their desire in twittering tones that suggest the voices of birds. Children, gay in their gorgeous rags, cling to the voluminous white trousers which form the classic attire of the Mauresque, as the Arabo-Berber woman of Algiers is called. But by far the greater proportion of the crowd in the Kasbah are men; clad for the most part in the native turban and burnous, though some few affect the loose Turkish trousers and the scarlet cap which is the livery of Islam. With the exception of an occasional Jew and a handful of negroes, the inhabitants of the Arab quarter represent all that is left of the Moorish population of El-Djezair.

Thus upon these labyrinthine ways you may meet every degree of poverty that rags and dirt can express, a poverty which implies, however, neither sorrow nor shame. The Oriental standard of comfort is not as ours; the luxuries for which we strive he disdains. That man in the shabby burnous, whose whole appearance suggests indigence, may well conceal a fortune behind the battered door that closes upon him like the gate of a prison. Sequestered within those inviolate walls are the 
two great mysteries of the East-its women and its wealth. Both are jealously guarded from the eye of the stranger; both are in the most literal sense of the word interred, for the manner of the Moor betrays nothing concerning the extent or quality of his possessions. He can be rich without ostentation, and poor without servility. Neither crime nor misfortune can divest him of the personal dignity which is his inheritance. A thief he may be, a liar frequently, but a vulgarian never.

In one corner of the Arab town there are open doors whose lintels are painted deep sapphire or cool green. Towards the close of day a wayfarer may discern, in the twilight of the interior court, a group of women lying under the shadow of an antique colonnade. Their garments, which veil everything except their faces, seem too diaphanous to bear the weight of the jewels that clasp them. They will offer to dance for you their eternal amorous provocation- $-a$ dance that is a strange blend of sensuous rhythm and hieratic gesture, solemn and lascivious at the same time. The love which they sell is almost as grave as death, but if you only seek peace they will take you up to the roof of the house, whence you may watch the daylight dying over the sea. In Algeria the carpet which the sky spreads for the expiring sun is suave as the robe of the dancer by your side. 
On all the neighbouring roof-tops you will see women in attitudes of repose, drinking in through unveiled lips the transparent evening air. She who gave me hospitality was called M'Barka, and did not belong to the Ouled-Nail tribe of official courtesans. She came from El-Oued in the Sahara, and would return thence when she had earned her dowry to wed and dwell in the tents of her own people. When the sea wind fluttered the innumerable louis-d'or that overhung her draperies of lilac and rose, M'Barka looked less like a Hindu idol, and more like a fairy princess strayed out of some lost record of Oriental love and chivalry.

But it was the departure of the great ships which really interested M'Barka. There was always one that slid out of the harbour about sunset, bearing its burden of travellers westward whence they came. She would follow its course with her slim, henna coloured hands, and articulate her childish wonder in words whose cadence seemed to me as comprehensible as the music of her tinkling bracelets. They expressed, harmoniously and unconsciously, all that in time and space lies between her and the hyper-civilized woman-between M'Barka and, let us say, a suffragette. And more of M'Barka's soul no Western will ever know.

That dance and others I witnessed later on-the decorous dance which is a prayer for mortal love, and the frenzy of those convulsions which are 
offered to Allah with the drugged soul of the dancer. Through the intervention of a Frenchwoman, who at the end of a life spent in the Orient had become more Arab than the Arabs, I was enabled to assist, dissimulated behind a screen, at this orgy of religious zeal. The occasion was almost unique, for few women ever accomplish the pilgrimage to Mecca, even when age and honour might warrant such temerity. But Khamissa was neither old nor honourable, and the grim clutch of phthisis reminded her of the tale of her sins. So the holy journey and the Bedouin between them devoured most of her ill-gotten gains, and what remained when she came back moribund to her house in the Kasbah was squandered in feasts whose object was to demonstrate to the neighbours her newly acquired sanctity. "A lordly pleasurehouse" is Khamissa's, with roses, virgin-white, climbing round the fluted pillars of the interior court. And upon the painted door the hand of Tanit-now attributed to Fatima, daughter of the Prophet-is branded, to affright the Djinn and other evilly disposed persons.

When we entered it was nigh upon midnight, and the dancing, which had begun at dusk, gathered energy as the intoxication gained the spectators as well as the performers. Rich carpets covered the marble floor, empty but for braziers from which mounted an aromatic vapour, at once 
poignant and oppressive. No men were visible, but on cushions disposed between the columns some thirty women crouched, scintillating with the gold that encircled their brows, their ankles and their arms, immobile as Byzantine frescoes in the incensed precincts of a shrine.

At the far end of the court an orchestra whimpered. Its music seemed to penetrate straight to the innermost nerve cell, dislocating the customary mechanism of sense and spirit. A murmur, that might have been a strangled reaction of the vocal chords, punctuated its crescendo, when suddenly one of the women arose, flinging herself, face forwards, on the thick carpet; then another, and another. No sooner had they touched the ground than a faun-like figure bounded from the shadow of a pillar and raised their prostrate forms, bending them this way and that in a rhythmic agitation. The music shuddered on, wailing and commanding by turns, and soon the court was filled with women's forms, executing in unison the same series of gestures, which slowly increased in speed as the music panted to a chorus of clashing bracelets. Presently the fever of the dance began to disintegrate the costume of the dancers. Hair escaped from the black bands and the golden fillets that bound it. Jewels and silken veils covered the floor upon which fell, one by one, the exhausted coryphants. Raised by the faun, they danced and fell again, 
and danced and fell till they could dance no more. In that ultimate hour nothing remained but a writhing and unconscious mass of colourflesh and scarlet and gold. The music shrieked; the roses, distraught, scattered their petals-their white and snowy petals. Khamissa, clad in the pilgrim's green, gazed upon the scene from her balcony on the first floor. Preceded by the faun, we staggered up the narrow stair, to eat with her the conserve of orange flowers and the other baked meats of hospitality. Gasping for breath. Khamissa lay, yet smiled. The grave seemed to yawnthe grave she filled next day.

I shall never forget that dance, nor Khamissa, nor the beauty of the dawn that greeted us as we emerged from the Kasbah. The air that invades those Algerian nights is limpid as a gem, imponderable, divine. The tremulous breeze which heralds the birth of morning seemed to encompass me like the waves of a crystal sea, and stars, resembling a myriad flowers - the white roses of Khamissa - hung like garlands in the sky. By the time I reached the hotel the events of the night appeared phantasmal, bearing no relation to the reality of my existence--to any existence.

Thus the Arab survives even in French Alger, for that which he has been despoiled of, to us essential, is to him superfluous. For him the picturesque dilapidation of the Kasbah, its walls 
painted like sea-shells and its vaulted streets, suffices, and will suffice. It is beautiful because his colour-sense is unerring, and its resistance to the onslaught of civilization is heroic, but it is a heroism which contains no hint of despair. The Arab quarter simply opposes its silence and its charm as an ironic comment on the vulgarity of modern aspirations. One has, however, only to glance at the old prints in the museums to realize the extent of that vandalism which seems to be an inevitable accompaniment of war. There are men still living who remember the mosques, the palaces decorated with faience and carving of ElDjezair, which were wantonly destroyed on the morrow of the conquest. But it must be acknowledged that the French, who are the most artistic nation in Europe, are doing their best to revive the lost art of Arab architecture. Among the services which the late Governor-General of Algeria rendered to the colony, not the least is the sympathy he manifested towards the Moslem subjects of France and all that concerns their past and their present. M. Jonnart realized that this style is better suited than any other to the country and climate, and it was consequently adopted for all recently constructed government buildings. Of these, the most successful example I have seen is the new barracks at Tlemcen. It is worthy of the city which contains the finest 
example of Moorish architecture in Algeria, the delicious Mosque of Sidi-Bou-Medine, built in I 339 by refugees from Andalusia. Its pure Saracen style has inspired the best modern house in Algiers, the office of La Dépêche Algérienne. Severe criticism has been lavished upon the new post office, but although it is not among the happiest of these experiments, it is infinitely more artistic than any hybrid French building would have been. The new villas which are springing up in every suburb of the town remind me of those which disfigure the environs of Cairo. As specimens of the grotesque united to the unpractical it would be difficult to choose between them.

From the Place du Gouvernement, with its crowded restaurants and tramways, radiate streets of tall, square houses bustling with the activity of a colonial capital-streets like cheap imitations of a Parisian boulevard. There is nothing imposing about the Place du Gouvernement but its name. Its sordid ugliness is barely redeemed by the glimpse one catches at its eastern corner of the Rue de la Marine and the perfect colonnade of the Great Mosque. The pedestrians, the loungers in the cafés, seem to belong to every nation, but the dominant type is Latin, without being quite European. It is a type in which the Spanish element appears to be the strongest, but there is Italian grace and French delicacy in it too. Many 


\section{IMPRESSIONS OF EL.-DJEZAIR Is}

of the women are beautiful, with a beauty I have seen on the road to Trastevere, in the old cities of Provence and in the orange groves round Valencia. But, added to all this, there is an indescribahle air of youth and exuberance as of an Oriental plant; of defiance to outmoded conventions and a rather reckless joy of life. Physiologically speaking, it is a fine type in the process of adaptation; psychologically it lacks Europe, with its self-consciousness, its neurasthenia, with everything that is included in that word, so discouraging to the scientist, so alluring to the artist-decadence.

But to appreciate the panorama of Alger, you must climb the hill to the east of the town, whose wooded slopes are called Mustapha Supérieur, and whose summit still bears the name of El-Biar. There are situated the villas of those residents who find the chief attraction of Algeria in its climateforeigners, for the most part, of every nationality. A few of these villas are old Arab houses, whose marble courts and terraces, encrusted with tiles, are the pride of their present possessors. But the charm of Mustapha is to be found in her gardens, where the flowers of two continents bloom under the shadow of tropical trees. There one may walk through fields of irises, hedged with roses and taxonias; there grow geraniums that reach the height of a man, and strelitzias whose orange and blue petals have the aspect of humming birds. 
From the terrace of the garden that I love you can contemplate the tendrils of English honeysuckle clinging to the branches of giant agaves which look like spikes of jade, and seem to belong more to the mineral than to the vegetable kingdom. And every bougainvillia thicket, every quivering palm leaf seems to exhale a perfume, which you trace at length to the waxen bell of the datura, in whose shade it is scarcely safe to sleep. This is "the beauty that is beyond perfection," on the rosy edge of decay, born of that alliance so fertile, if not precisely holy, between the South and the East.

On the cliff above the Peñon one can just distinguish the domes of Notre Dame d'Afrique, the cathedral which owes its existence to the dynamic energy of that crusader, the Cardinal Lavigerie. His statue looks to-day across the square in Biskra towards the illimitable desert which he strove to win for Christ. Did he realize, I wonder, ere he died, venerable and disillusioned, that Allah had for once conquered the Galilean whom he worshipped with such a martial ardour? If so, he made no sign, and the Arabs, who know a great Christian when they see one, loved him well. Around the pseudo-Arabesque of his church winds a road which bears the name of the Chemin des Consuls, and once belonged to a rather remarkable person, Sir Lambert Playfair by name, for many years British Consul in Algiers, and as fervently 
 


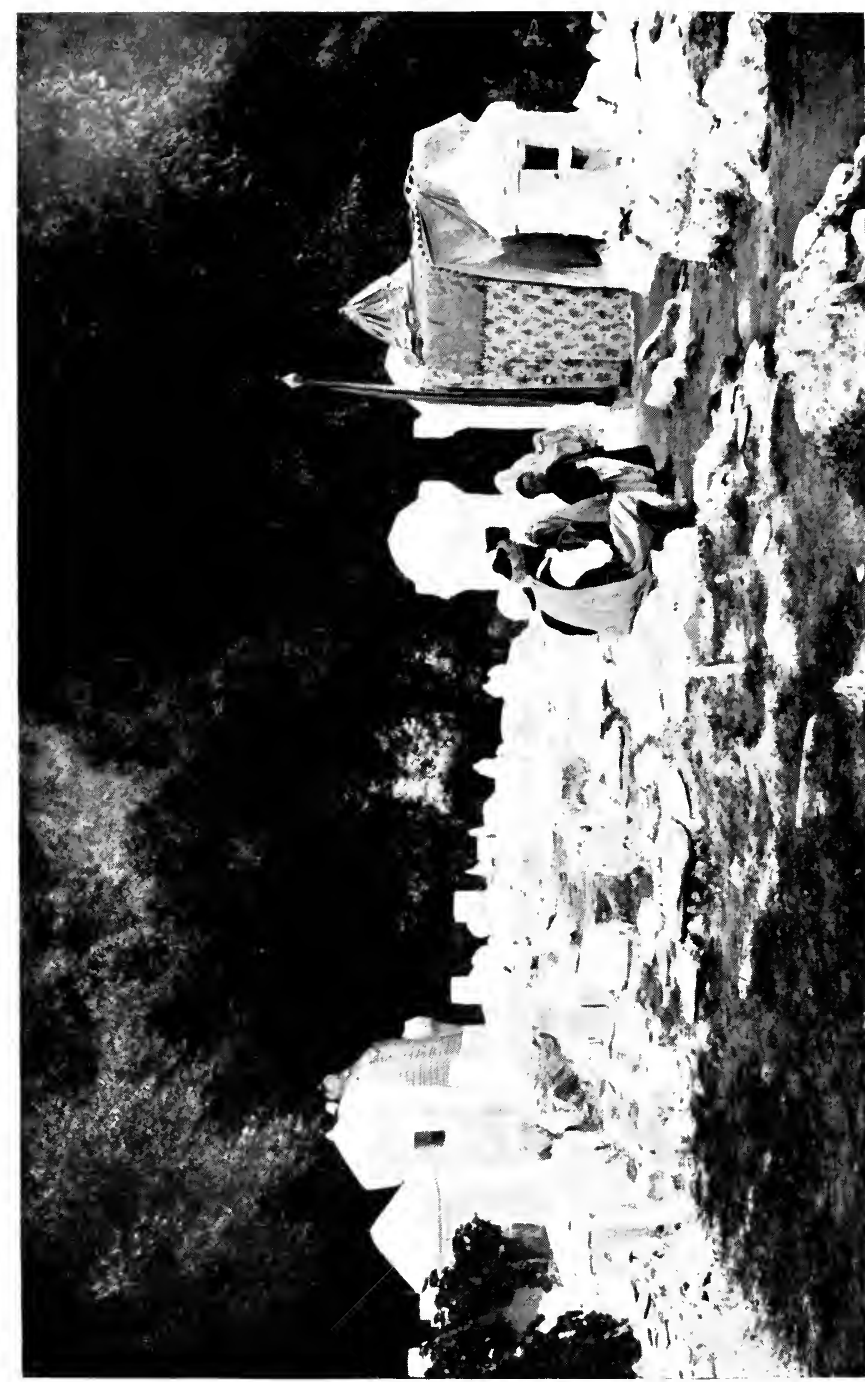

空 
interested in the struggle between Christ and Mohammed as the Cardinal himself. The author of The Scourge of Christendom reminds me that time was when Englishmen were more numerous in Algeria than they are to-day. Some of the loveliest villas amid the gardens of Mustapha are still owned by the remnant that is left, since the law of automatic naturalization passed the Chambre des Deputés in I889. By its provisions all children born in Algeria of foreign parents became French, and subject to military service in the French army, unless they maintained their British nationality by declaration on attaining their majority. But even if they refused naturalization for themselves, they could not do so for their children. If born in the colony, they became subjects of France whether they would or no, and this eventuality has undoubtedly reduced the English element in the population. However far his feet may wander, however he may curse his native climate, the advantages attached to British citizenship generally become the more apparent as he enlarges his acquaintance among the subjects of other powers.

The last rays of the setting sun always illuminate the Peñon, that sturdy tower standing beaconlike out to sea, where Pedro da Navarro branded the arms of Spain four hundred years before France realized her dream of a colonial empire. From 
the gardens of Mustapha one might have watched the Corsair Baba-Roudj sail into the bay at the call of the Sheikh Salim to expel the Spaniard and to reign in his stead. And watching to-day one may beget with comparative ease that state of mind whose primary emotion is a passionate acquiescence in those ideals which have ceased to inspire one's generation, and whose recrudescence would be its death. They are the ideals which exalted the individual at the expense of society, and which, once upon a time, made the northern shore of Barbary so beautiful, so exclusive, and, incidentally, piratical.

If the attitude of the Arab towards life is very different from ours, his attitude towards death is more different still. To realize all that divorces Eastern from Western sensibility, one should visit an Arab cemetery and walk among those gay little graves that jostle each other on the incline of ElKettar or under the cypresses at Belcourt. Each Friday before noon these cemeteries are full of women coming, with sprigs of myrtle in their hands, to visit those who have "entered into the mercy of God." No men are permitted within the gates, for the women, who do not come to mourn, cast aside their veils on these occasions. They sit in white and chattering groups upon the tiles of the tombs, drinking coffee and eating bon-bons, while the children gambol beneath the fig tree's shade. 
Everything smiles in an Arab cemetery, even the crooked, coloured stones. There is no trace here of that gloom which makes a Christian graveyard a place of grief and horror. Islam, with its unassailable faith, its conviction of immortality, takes even the sting out of death.

But one must go as far as Blidah, some thirty miles south of Algiers, to see the fairest cemetery in Islam, as fair within its miniature proportions as those famous sanctuaries of the dead on the Bosphorus. All that the tourist generally sees of Blidah are its forests of orange trees and the monkeys which inhabit the Gorges de la Chiffa. It were more profitable, maybe, to make a pilgrimage to the tomb of Sidi-el-Khebir, one of the numerous warrior-saints of Islam, who sleeps surrounded by his descendants in the valley which bears his name. His grave is a shrine of sculptured wood, with, at his head and feet, a dome or koubbah, white as the burnous which covered him alive. At his right hand is reared the standard of the Prophet, piercing the silver foliage of the olive trees which overhung the valley long before Islam had crossed the African frontier. Just beneath the cemetery wall an old Sheikh, seated on a mat, teaches a score or so of children to recite the sacred sourahs. So, like the Bishop of St. Praxed, Sidiel-Khebir has a grave such as any saint might envy, where "all day long all through the centuries he c 2 
can listen to the blessed mutter" of the Koran as it ascends into the firmament, incensed by Blidah's hundred thousand orange trees.

Algeria may be justly compared to a palimpsest, for over her mountains and her plains all the civilizations of the world have passed in turn, first their armies and then their colonists. Stones are there, still one upon the other, that resounded to the march of the Roman legions and to the thunders of Augustine, Saint and Father of the Christian Church. Then out of the night that swallowed up the empire of the Cæsars, came the Vandals, with hair like flax and eyes like the irises that grow in the gardens of Mustapha. To them, as to the African blend of Numidians and Romans, Islam offered, two hundred years later, the choice of death or the Koran. Thus the fecund Tell and the solitudes of the Sahara rang for centuries with the praise of Allah. There grew up, then, in Africa, as wherever Islam led its armies to victory, a new and exquisite form of art, for the illusion that beauty is the child of peace is of modern fabrication. Bruges was a slaughter-house when Memlinck painted his liturgic Virgins, just at the time when the Merinides in Tlemcen set about building those temples whose blanched cupolas and enamelled minarets seemed to blossom out of war. Then the French came, bringing knowledge to take the place of beauty, of which supersession, if we 


\section{IMPRESSIONS OF EL-DJEZAIR 2 I}

are to believe Nietzsche, tragedy is born. In Nature, as in mankind, this country exhibits the same diversity in which the unexpected always happens, the same contrast in which extremes always meet. You can abandon the Tell where there is everything for the desert where there is nothing. You can live any life in Algeria, die any death and sleep thereafter, if such be the will of Allah, looking seaward from El-Kettar.

"Men who give up too much time to travel grow at last to be strangers in their own land." These words are the words of Descartes, and they are true. So let it be. 


\section{CHAPTER II}

\section{KABYLIA OF THE BERBERS}

Ethnologisms whose interest is aroused by the mere fact of remote origin, should find in the history of the Kabyles an incomparable field for research. Even the simple traveller is impressed when he discovers in the course of his wanderings a race who can trace its descent back to the Flood. It is not every day that one has the chance of observing a people whose ancestors were those Canaanites who heard Joshua call upon the sun to stand still. In Ibn-Khaldoun's History of the Berbers, written in the fourteenth century, he declares them to be the progeny of Shem of the family of Noah. For the Kabyles are none other than Berbers or Numidians, originally, according to Sallust, a remnant of the army of Hercules.

This view is endorsed by no less an authority than Renan: "The Kabyles," he asserts, "were brought into the country neither by the Moslem conquest nor by the Romans. They are neither Vandals nor Carthaginians, but aboriginal Numidians, descended from the subjects of Massinissa, of Syphax and of Jugurtha." And the 
mountain ranges east of Algiers are still densely populated by these Kabyles-a name probably derived from the word Kbail, signifying tribeswhose genealogy makes parvenus of all the European races. There one may meet face to face men who fought against Lamoricière, just as their forefathers fought against Roman consuls and medieval Spaniards, before scattering the mercenaries of the Ottoman Empire. And those women, whose unveiled faces are painted with carmine and tattooed with indigo, are the children's children of those who welcomed Queen Dido and her Phœnician guard when they sought refuge among a primitive people speaking a common language nearly a thousand years before the birth of Christ.

The haze of an April morning lay upon the vineyards as I tore over the featureless road that unites Algiers and Tizi-Ouzou, an important town on the edge of Kabylia, whose name sounds like the languid protest of a locomotive. We had wisely arranged to pass through Tizi-Ouzou on a market day, when its dirty streets are crowded with Kabyles, who bring down their produce of olives and figs to sell to the European merchants. We had thus an opportunity at the very outset of our journey to note the difference in type between the Kabyle and the Arab. Despite the mixture of blood, the former, who generally bares his head and feet, is fairer than his nomad neighbour. 
Pale eyes often light their rugged square faces, and the hair that frames them is sometimes red or even blonde. A relic, this tint is thought to be, of the Vandal invasion, which added a drop of Teutonic blood to a race that already owed a debt to Phœnician colonists and to Roman conquerors.

The highway which, after leaving Tizi-Ouzou, crosses the valley of the Sebaou and winds round the slopes of the Aissa-Mimoun, was constructed by the French for strategic purposes. It marked one stage in the struggle which was only half terminated at the building of Fort-National in I857. For the dominant characteristic of the Berber race is its fierce independence. All down the stream of time they have, after assimilating the various civilizations brought into their country from without, always ended by triumphing over their vanquishers. From Carthage these Numidians first adopted its agricultural and commercial knowledge; then from Rome its language and customs, with its nascent Christianity. This fusion through propinquity and intermarriage was so quickly accomplished that the African subjects of Cæsar grew to equal those of the Metropolis in culture and learning. Many of the illustrious names that gilded the pomp of Rome came to the capital across the Mediterranean Sea. Of such was Apuleius, the philosopher, the sainted Augus- 
tine and Septimus-Severus, born at Leptis, who reigned several centuries later.

Meanwhile the vassal kingdom of Mauretania, as Roman Africa was called, continued to be goverued by native princes. Upon one of these, Jubal II, renowned even to-day for his wisdom and scholarship, Augustus bestowed the hand of Selene-love-child of Antony and Cleopatra-who was dedicated by her mother to the moon. For her sake Jubal built a city, the lily-white Cæsarea, home of poets and philosophers, second only to Rome in beauty and wealth.

But the luxury of Cæsarea and Cirta, and the doctrinal differences which tore the Christian Church in Africa, all fell before the Vandal swarm. Civilized themselves in course of time by the Berbers, the Vandals were equally engulfed in the second Arab invasion of the eleventh century, which carried the Koran from Tripoli to the Atlantic. Kabylia, which had to a certain extent resisted the onslaught of Sidi Okba in A.D. $68 \mathrm{I}$, was ultimately swallowed up in the Moslem cyclone. When the Arab civilization replaced that of the Cæsars, the Berbers again manifested their extraordinary capacity for turning their enemies' sword into a ploughshare. In Les Musulmans Français du Nord de l'Afrique, M. Ismael Hamet demonstrates the extent to which the Berbers pushed their imitation of their conquerors. Under 
the Saracens, Bougie in Kabylia became one of the cities from whence the light of science and letters shed its effulgence over the whole African coast.

Detached in the fourteenth century from the vast empire, whose Court was established at Tlemcen, Bougie was for a time the centre of an independent State, till its prosperity aroused the cupidity of its Spanish rivals. In I 5 Io it fell a prey to Pedro da Navarro, who experienced, however, much difficulty in retaining his hold upon it. Nor was the reign of the Spaniard of long duration in Kabylia. The advent of those intrepid Corsairs, Baba-Roudj and Kheir-ed-Din, imparted fresh hopes to the indomitable Berbers. A few years later the beleaguered successor of Pedro received a safe-conduct back to his own country, there to find Charles $\mathrm{V}$ indisposed to leave his head upon his shoulders. After this interlude Bougie sank into obscurity, and the fortunes of the Berbers became more and more identified with their mountain strongholds. There the population was constantly engaged in guerilla warfare, either between rival tribes or against the despotic Turk. Never did these Ottoman rulers succeed in entirely subduing the Kabyles, and entrenched in the inaccessible Djurjura, they subsequently gave the French as much trouble as they have always given intruders, Not even the erection of Fort-National 


\section{KABYLIA OF THE BERBERS}

-that "thorn in the eye of Kabylia," as the natives call it-upon the confiscated territory of the Ait-Iraten, dominating the equally turbulent villages of the Ait-Fraoucen and the Beni-Yenni, reconciled the inhabitants to saluting the French flag.

But the resurrection of 187 I should not be wholly attributed to the contumacious humour of the Kabyles. It was largely the result of the illtimed enfranchisement of the Jews, and of other mistakes made by the French administrators, who were even more ignorant of Kabylia and its people than they were of the desert Arabs. I admit that I cannot withhold my sympathy from that magnanimous rebel Sidi Ahmed-el-Mokrani, who led the last fight made by the Berbers for freedom. Too generous to strike at France while she was defending herself against German aggression in 1870, he further gave notice to the Government of his intention to open hostilities before the first shot was fired in 1871. "C'était magnifique mais ce n'était pas la guerre," and when El-Mokrani fell after much bloodshed, the ribbon of the Legion of Honour, bestowed on him in the hope of converting a chivalrous enemy into a friend, was found tied to his horse's tail. Some months after my tour in Kabylia I stood beside his grave in the sunlit cemetery of Belcourt. Out of ElMokrani's heart grows a great tree, a sturdy carob, 
and, like himself, more easy to break than to bend.

These memories beat like cymbals upon my mind as our car panted round the shoulder of the mountain, cloaked by olives, almonds and fig trees. As one ascends the entire range comes into the line of vision, intersected on every side by gorges which gives an expression of carefully tended fertility. But the finest view of the untamed beauty of Kabylia is to be seen from the citadel of FortNational. In the foreground the sterile peaks of the Djurjura pierce their cerecloths of cloud, while from their stony flanks spring satellite ranges, which extend in every direction like the crenellations of an impregnable fortress. Poised upon each summit are the nests of the Kabyles, a cluster of gabled roofs clinging limpet-wise to the rock. Far beneath them the eye plunges into profound ravines, where abundant foliage seems to belie the chill of the mountain-tops. Fields of flowers, azure and gold, line the valleys, sharing the rich earth with almond and ilex trees, blossoming acacias and the misty silver of olives, whose origin must be as antique as that of the people who cultivate them.

Round the crest of the Djurjura curls the road to Michelet-a road such as only the French can build. Again and again I stopped the car to gaze into those depths of crimson and green, for the 
soil of Kabylia is as red as the roofs of its villages. It is impossible to believe that this is Algeria, that a few miles to the south lie the steppes of the Atlas, and just beyond them the burning amber of the Sahara. Nor is it easy to define in words the charm of the Djurjura, with its riotous vegetation creeping up almost to its ice-laden crags. Sometimes a naked peak reminded me of Norway, more often a wooded ridge suggested the Haute-Savoie. But nowhere else in the world does there exist that marvellous combination of northern wildness and southern luxuriance which characterizes this last refuge of the African Berbers.

Silence is golden with regard to the inns in the 1)jurjura. Cleanliness is the only virtue I can honestly impute to the hotel at Michelet where we spent that night. Early next morning I started on the back of a dejected mule to visit the villages of the Beni-Yenni. These cover a region not exceeding 3,500 hectares $(8,645$ acres) in size, which harbours a population numbering nearly 7,000 souls - a density equal, if not superior, to that of Belgium. Let me confess at once that distance lends enchantment to these Kabyle villages. Their houses, built of the roughest stone, lean up against each other like paralytics, and are innocent of either comfort or decoration. Both within and without these hovels a busy activity prevails, for, unlike the Arabs, the Kabyles are 
extremely industrious. Those tribes who are not absorbed in the cultivation of the soil-olives and figs being the staple produce-have developed a considerable trade in the manufacture of smallarms and cutlery. One of the villages of the BeniYenni is exclusively occupied in the reproduction of those curious ornaments of enamel and silver worn by the Kabyle women. Needless to say, little silver is used in the making of these base imitations destined for the unwary tourist. No sooner had our modest cavalcade entered the narrow street of Taourirt-Amokrane than we were surrounded by a crowd of importunate vendors, each vaunting the quality of his trumpery wares. Nothing could be more picturesque than the striped dresses of the women, many of whom are beautiful in a fair Scandinavian way. Their garments of tattered vermilion and blue are fastened round their lithe bodies by quaint shoulder straps and a breastplate of silver, elaborately worked and inlaid with red enamel. The men, even those who have not the excuse of poverty, content themselves with the simplest vesture; usuaily a long gandourah, or smock of white woollen stuff. The passion for personal adornment, innate in the Arab, is unknown here.

Nothing demonstrates the essential differences between these two native races of Algeria more than the spirit of democratic equality which 
inspires all the social and political customs of the Kabyles. Their institutions are much older than their acceptance of the Koran, and are in some instances at variance with its precepts. They have retained them much as the Japanese retained the Cult of Ancestors after their conversion to Buddhism. The historian Charveriat sums up the Berber constitution as follows: "Before the French conquest, each village or thaddert formed a miniature republic absolutely autonomous, where the system of self-government received the most radical application. It was, in the most literal sense of the words, the rule of the people by the people." This sovereignty is incarnated in an assembly of notables, called the Djemma, which regulates the affairs of each village, though their decisions are to-day subject to the approval of the French administrator. The predominant influence or sof in the Djemma changes according to the prevailing sentiment in the little community almost as parties alternate in our modern parliaments. In former days executive power was vested in a delegate, or amin, who had, however, no authority save that which the council bestowed upon him. It was the sof that contracted alliances with neighbouring villages, that organized the periodical battles between them, relentless combats in which no quarter was given. 'They were presided over by the women of the respective tribes, 
who, adorned and painted as for a festival, encouraged their husbands and brothers to conquer or to die.

This brings me to another remarkable contrast between Kabyle and Arab customs. For although the position of the Kabyle woman is subordinate to that of the man, by whom she is literally bought and sold from the cradle to the grave, she possesses privileges which Arab society denies to its feminine members. The former has from time immemorial been permitted to circulate freely and unveiled, not only inside her house, but also outside it. She is, moreover, the sole wife of her husband, but as divorce is easy and frequent, this advantage is more apparent than real; especially as her husband can, by placing an exaggerated financial value upon her, prevent her from contracting another marriage. Apart from this relative monogamy, the Kabyle woman shares her husband's meals even when strangers are present, and, when aged, her counsel is frequently sought in the market-place by the elders of the tribe. They did not presumably do so, however, on that day in 1749 when the Djemma decided to deprive the weaker sex of those rights of inheritance which the Koran conferred on all Moslem women. Since then the Kabyle woman can only succeed to the property of a deceased male relative if no man rises up to contest her claim. 


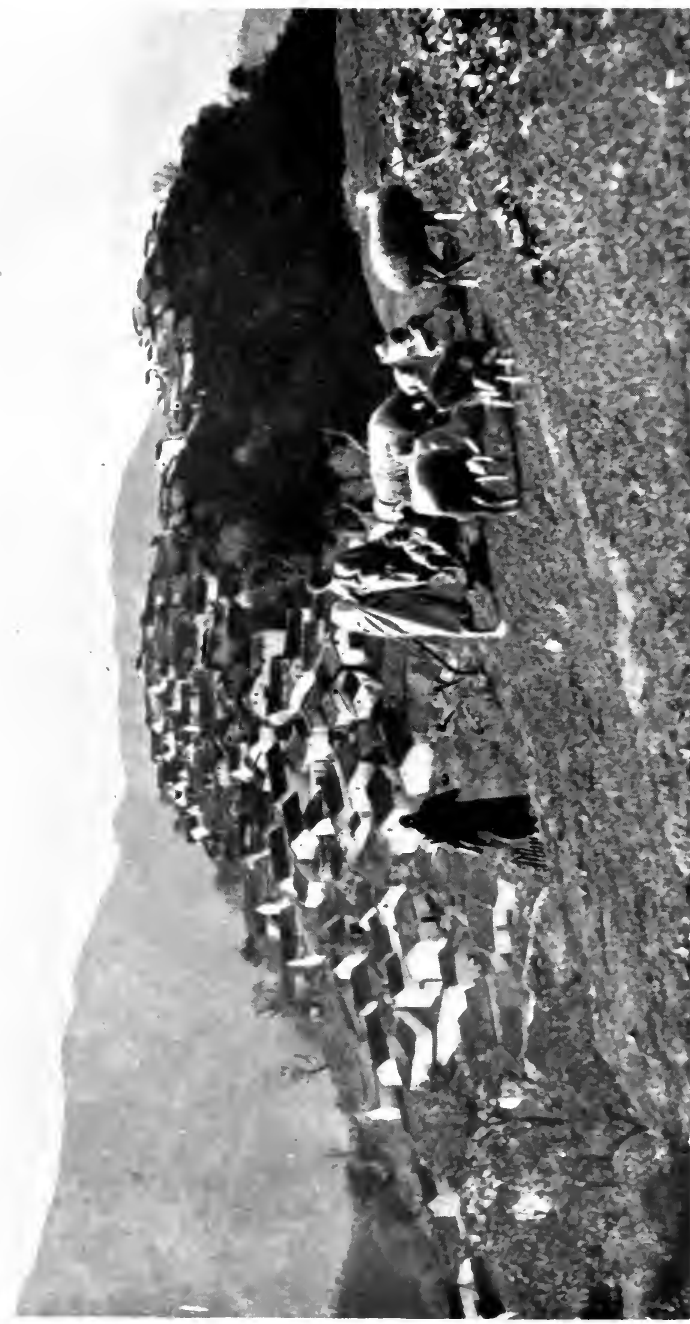

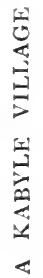



Nor is this disability the only drawback to her liberty of movement. More free, she is also more energetic, and is therefore called upon to bear a larger share of the day's work than is inflicted on the Arab woman, whose sheltered existence frequently connotes a degree of comfort and ease which the Kabyle woman never enjoys. As I rode back to Michelet through a thin rain, a reckless purchaser of native jewellery, I wondered which destiny would seem preferable to a European consort-to sit veiled " in sandal-scented leisure" at the door of a tent, or to fill through laborious years those great jars containing provender, which constitute the sole furniture in the miserable homes of the Kabyles?

Another offshoot of the great Berber familythe Touaregs-differ from the Kabyles in their attitude towards woman as they do in their errant and predatory habits. A witty French writer has described the Touareg women as "veritable Americans of the Sahara." Not only do the feminine members of the tribe enjoy entire freedom, but they take an even larger share than their husbands in the direction of its destinies.

Next morning's fitful sunshine watched us on our way towards the highest point of the Djurjura, where the road passes at an altitude of 5,300 feet over the Col de Tirourda. Out of the cloud-fleeces soared the virgin peak of Lalla- 


\section{4}

\section{ASPECTS OF ALGERIA}

Khadidja, companioned by the sharp summits of the Aboukir and of the Azerou-Tidjer ranges. Mounting, we gradually lost sight of those radiant valleys, which are the pride of the diligent Kabyles. A few sparse olives still clung to the ledges, but when we reached the Maison Cantonnière, even their wind--swept branches had disappeared. Our motor hugged the sheer incline of Azerou-nTirourda, where snow still lay in the clefts like white niches in a tower of porphyry. Three gnarled cedars sentinel the last turn of the road as it glides into a tunnel cut through the living rock. A moment more and we had emerged upon a grassy declivity, while far across the valley stretched the long chain of the Atlas. All down the interminable descent into the Oued-Sahel we saw those mountains, blue as the illusions of youth, through forests of olives and cork-oak. The Lesser Atlas lack completely the dignity of the Djurjura, their beauty consisting in the pearly atmosphere which envelops them. At Tazmalt we found ourselves once more on level ground, with a vague feeling of approaching disenchantment, and during the forty-two miles of highway which skirts the Oued-Sahel, that presentiment was more than fulfilled. A stream of sluggish, evil-smelling water crawled along the river-bed, and when we entered the little port of Bougie the shadows were grey in the west. 


\section{KABYLIA OF THE BERBERS}

This climbing town seems to regard the sea with a coquettish air that ill consorts with the stern aspect of the Bab-el-Babor, sole relic of the walls which encircled Bougie during the brief glory of the Hafecide Empire. There is nothing of interest in the place itself, but our itinerary included a drive to the Chaabat-el-Akra, or Defile of Death, a narrow gorge which cleaves to the heart of the Babor mountain, as the tree-clad heights following the coast-line are called. Our road lay through miles of vineyards growing right down to the shore until, turning abruptly inland, we entered a valley whose steep sides nourish millions of ilex and cork trees. Farther on, the gorge contracts into a winding defile with the dates " $1863-70$ " branded upon its rocky brow in commemoration of the construction of the road. Here the colour of the soil is less sanguine than that of the 1)jurjura, but I observed on the opposite side of the valley a series of tunnels united by a light railway, which were, I afterwards learnt, the workings of recently discovered iron-mines. Lunch at Kerrata, the village at the head of the gorge, provided an agreeable diversion, for it was a good lunch. Thereafter, instead of retracing our steps, we turned, on emerging from the Chaabat, along the lovely coast-road leading to Djidjellianother triumph of French engineering. It overhangs the sea, circling the cliffs of the Babor, and 
is as beautiful as the famous Corniche of the Riviera.

The inhabitants of this region do not apparently possess the hardy virtues which distinguish the tribes of the Djurjura. Forests of cork-oak cover an immense area, and in consequence the population is less dense than in the cultivated portions of Kabylia. It must not be thought, however, that the entire Berber race is confined to these mountain chains of the Tell. All through Algeria, in the Ksours, or fortified villages scattered over the High Plateaux, and in the oases of the Sahara, natives of Berber extraction are to be found, mixed either with Arab or in the far south with Negro blood. The Kabyle builds for himself a fixed abode wherever he goes, for he is devoid of the nomad propensities peculiar to the Arab of pure strain. When these wanderers drive their flocks northwards to the pasture lands it is the Berber of the Ksours who is their customer, who stores their grain and buys their beasts. Each mutually despises the other, but this latent antagonism does not prevent commercial relations and occasional intermarriage among the poorer class. They speak the same language, for the ancient Berber tongue, originally quite distinct from the Semitic languages, has degenerated into a bastard dialect whose very alphabet is lost. For centuries Kabyles have used Arabic for trading purposes, and the 
Arabic characters when they write their own tongue. If any literature ever existed, no trace of it remains to-day. Kabyle tholbas explain this deficiency by declaring that all their manuscripts were destroyed in the Spanish sack of Bougie. No evidence exists, however, in support of this assertion, which most historians, including General Daumas, discredit.

Of all the towns upon the Barbary coast, Bougic has the highest rainfall, and the showers which drenched us during our sojourn there reminded me of this pre-eminence. In default of fair weather we were compelled to abandon our motor and return to Algiers by train. This was my first - and, I trust, my last-experience of the EstAlgerien line, which then possessed every defect that could detract from the utility of a railway service. Since that date the Est-Algerien has been. bought by the Government. Even persons who are opposed on principle to the State control of railways could not but admit that, whatever changes may be inaugurated upon the Est-Algerien, they must be changes for the better. Hitherto the only way of visiting Kabylia without incurring considerable discomfort has been to travel by automobile. And this difficulty of transit is responsible for the fact that only a small proportion of winter residents in Algeria ever seek to penetrate the interesting land of the Berbers. 
There exists on the fringe of the Sahara a republic of seven cities called the M'Zab, whose inhabitants claim to be another offshoot of the Berber race. If not exactly aboriginal, they are certainly as old as the Phœnician refugees, and seem to have inherited the commercial genius of those wily Levantines. The towns in the Tell are full of Mozabite traders, who remain just long enough to acquire the riches which they spend in converting their desolate chebka home into a garden. By means of deep wells, whose whining pulleys are the national anthem of the M'Zab, the inhabitants have created a veritable oasis, upon whose rim five of their seven conical towns are poised. The most important of these hive-like pyramids of Mozabite industry and isolation is Ghardaia. There is the seat of the French Government which has been accepted by the Mozabites since $185 \hat{j}$, although the formal annexation of the M'Zab did not take place until I889. Since then the decisions of the Djemma have, as in Kabylia, been subject to ratification by the French Commandant. But this supervision is more formal than real, and for all practical purposes the M'Zab remains the autonomous republic it has always been.

Schismatic Moslems and members of the Ibadiyah sect, the Mozabites are treated by the Arabs as renegades, and their territory as accursed. For 


\section{KABYLIA OF THE BERBERS}

their part, they invariably try to avoid any contact with their orthodox neighbours. None are permitted to inhabit the M'Zab, and in the sacred city of Beni-Sguem no stranger is allowed either to smoke or to sleep. Heterodox as the Mozabites are, they profess a severity in the exercise of religious and social duties which has earned for them the title of the Puritans of Islam. The inhabitants of Berryan and Tilrempt, with those of Ghardaia, Melika, Beni-Sguem, Bou-Nourah and El-Atef do not, all told, exceed 25,000 souls.

In comparison with the M'Zab, Kabylia is quite accessible, for three hundred miles of rocky waste divides Ghardaia from Berrouaghia, the terminus of the railway. Automobilists will find the road excellent as far as Laghouat, after which they can only cover the remaining 120 miles across the chebka at the peril of their tyres. This table-land of crumbling stone, seared by the sun and worn by the rain, is interrupted by valleys called dayas, where wild jujubiers fight for their lives with the great betoum or terebinth trees. But the towns of the M'Zab, with their pointed minarets, seem to rise out of a magic ring of gardens, where, under 170,000 palms, pomegranate flowers glisten like drops of blood among the blossoms of peaches and apricots. Another monument of Berber tenacity are these oases of the M'Zab. In such a wilderness no man cared to argue their pretensions, 


\section{0

so the Mozabites concentrated their energy on bending Nature in her most stubborn mood to their will. They have succeeded far beyond the success of mere survival, for now they are literally able to gather "grapes from thorns and figs from thistles." Gold, too, they gather abundantly during their brief exile on the coast. The Arabs declare that while it takes two of them to outwit a Jew, two Jews have little chance of outwitting a Mozabite. Their hand is against every man, and somehow it is always full-the hand that, when even Africa was young, tended the gardens of Tyre and Sidon. 


\section{CHAPTER III}

THE ROMAN PROVINCE OF MAURETANIA

Circumstance rather than intention was responsible for the awakening of my interest in those first five centuries of our era during which Algeria intermittently formed part of the Roman Empire. The idea of interrupting my southward pilgrimage had never occurred to me until I found myself turned out of the train at Batna on a June morning, with the information that I could not continue my journey to Biskra till the burden and heat of the day were past. The prospect of ten hours in the dismal town of Batna was not to be endured, and I was just about to accept the invitation of a fellow-traveller to spend the day in his cedar forest on the Chellala, when I remembered the proximity of Timgad. The only way of reaching these stupendous relics of Roman power in Africa is a four-hours' drive across an arid plain, and that prospect made the shade of the cedars seem even more alluring. But I knew how speedily remorse would follow my realization of a missed opportunity. So after a hasty luncheon at the station buffet I started for Timgad, armed with 
an official letter from the amiable prefet of Batna to the directeur $d u$ service d'antiquités, who supervises the actual work of excavation.

From the point of view of comfort my equipage left everything to be desired. Its angles reminded me of the Cape cart in which I crossed aforetime the South African veldt, to which the scenery round Batna bore a vague resemblance. It manifested the same lamentable lack of character until a turning in the road revealed the distant quadrature of a colossal portal which marked the entrance to the ancient town of Lambæsis. Its presence seemed to emphasize both the insignificance of the adjacent modern houses, half hidden by timid trees, and the sinister aspect of the prison, all rendered equally rigid by the suffocating heat which seemed to emanate rather from the earth than from the sky. A few minutes more brought us to the village where the horses, already exhausted, stopped suddenly by the door of a café. Leaving man and beast to refresh themselves, I walked to the museum at the end of the shady street, where an old soldier watches over a mass of broken statues, lamps and pieces of moneythe ordinary débris of a ruined Roman town.

One beautiful fragment of mosaic adorns the walls, but my wandering glance was riveted by a rough triangle of white marble which had the aspect of a funereal tablet. Upon it was engraved 
in letters of faded gold the august and infamous name of "Faustina," beneath the profile of a roman's face. It was a face at once mystical and passionate, imprinted as it were upon the stone by the force of a whole nation's desire. "Faustina"! How imperial the letters looked in their decorative design, even though they had obviously naught to do with the consort of Marcus Aurelius! Who was this African who had borne in life that illustrious name, and in death had underlain that marmoreal snow? A simple matron of Lambæsis, or perchance a Roman virgin, spotless as the colour of her tomb? There was nothing to indicate, for time had even divorced her monument from her dust. Yet to me she stood for Aryan civilization and all it imports on that torrid afternoon in the midst of Dar-el-Islam.

The twilight sky had begun to mate with the desolate plain when the two gaunt pillars that signal the place of the Capitol at Timgad appeared upon the horizon. I watched them till we drew up at the hotel, hastily opened to receive a belated traveller. My hunger was scarcely allayed when the directeur, M. Barry, called with the proposal of a nocturnal visit to the ruins. The golden African moon was full that night, and the antique ways of the vast sepulchral city were flooded with a light more fair than day, whose reflections were deep and angular as mathematical diagrams. 
Nothing but the noise of our footsteps disturbed a silence in comparison with which death itself seemed articulate - the silence of things immutable yet outgrown. Stones filled the whole vista on every hand, shattered yet guarding the legend of their utility, substantial still with all the majesty of Rome. Here stands the skeleton of public baths, heated as they would be to-day; there an imposing colonnade which once graced the house of a wealthy citizen of Thamugadi. Twelve steps lead from the Decumanus maximus to the rectangular space of the Forum, framed by a double row of pillars, some of which have been reinstated. But the equestrian statues, that decorated the roofless square, are gone, though on lingering pedestals one can read the names of Emperors and Governors of the province of Mauretania. Flat tables of granite, solid yet, were evidently used for cards or dice, and upon the worn edge of one it was possible to make out the following words: "To hunt, to bathe, to play, to laugh-such is life!" An aphorism that sounds of yesterday, an intimate touch, welcome amid so many frigid symbols of departed greatness.

Behind the Forum, on slightly rising ground, coils the semicircle of the theatre. Constructed about the middle of the second century, it could accommodate some 3,500 spectators. From the summit of this montecule one can view the whole 


\section{PROVINCE OF MAURETANIA 45}

extent of the ruins. The whiteness of the moonlight rendered even more pathetic their abandonment to the corrosive touch of time. Columns replaced, some entire, some truncated, seemed to take on the attitude of an army, desperate, heterogeneous, but united to resist the march of years. 'The triple arches of Trajan's Gate arrests one end of the long Decumanus maximus, and beyond the thermes on the southern edge of the town the ruins of the Capitol affronted the stars. Two columns, fourteen metres high, which have been re-erected by the French excavators, shone ghostly -dead commanders, one might say, of a decimated host.

Near the Capitol was the principal market, and two hundred yards to the south-west the ruins of a huge basilica have been discovered in the heart of the Christian town, which was almost as large as pagan Thamugadi. Outside the perimeter of these twin cities a Byzantine fortress guarded, in the sixth century, one of the secret underground passages which led to the Aures Mountains.

At daybreak on the morrow M. Barry was kind enough to show me a beautiful Christian bapistery which had recently been excavated. It was deeply buried among the débris of a crypt, and owing to this fortunate accident its mosaic is in perfect preservation. Octagon in form, the little chapel consists of three steps descending into an open font, 
inlaid with Christian emblems in coloured marble. In the museum many fine mosaics have been collected, chiefly from the pagan city. The earliest, though somewhat archaic in design, are remarkable for their brilliant and harmonious colouringsuch as the "Diana surprised in her Bath by Acteon," taken from the house of one Faustus. Others, like "The Elopement of a Nereid," exhibit the subtle grace characteristic of the best Greek designers. Many domestic objects and a few statues, much damaged, bear witness both to the prosperity of Thamugadi and to the industry of the Service des Monuments Historiques.

This outpost of the Roman Empire owed its existence to Trajan, and was originally the camp of the Third Legion, " the August the Victorious," epithets yet visible on the rock by which it passed to the subjugation of Numidia. It is doubtful whether Thamugadi ever attained the importance of Cirta, afterwards called Constantine, which became the capital of the province after the destruction of the famous coast-town of Cæsarea by Firmus the rebel in the fourth century. It was not, however, until the reign of the Antonines that the African provinces became an integral part of the Empire. The civilization of Rome had by that time taken root on the southern coast of the Mediterranean, and when the doctrine of Christianity followed, its reception by the African races 
was as enthusiastic as it had been reluctant in Gaul. The practice adopted by the primitive Church of appointing bishops not only to the large, but to the smaller towns, tended to enhance the splendour of Christian ceremonial, and to promote the spread of its tenets. But the glory of the African communion really resides in an accident of birth which enables it to claim as its sons three of the most celebrated Fathers of the Church. Of this trinity the greatest was St. Augustine, who more than any single man may be said to have directed and developed Christian thought. To some extent, however, his dogma was evolved out of the writings of Tertullian, born, like himself, in Africa about a century earlier. The third of this trinity was Cyprian, native and Bishop of Carthage, martyred during the Decian persecution in A.D. 258.

A little discretion would probably have permitted that distinguished epistolarian to expire de sa belle mort in the seclusion of his Carthaginian villa. For the number of Christians done to death in these persecutions has been grossly exaggerated, though some of the misrepresentations of ecclesiastical writers were corrected by another Father, the learned Origen. Tolerance was an attribute of the pagan world, and in those centuries which preceded the subversion of the Roman Empire the Christians enjoyed long periods of peace and sometimes of protection. Most of 
the Emperors, not excepting Diocletian, only gave the signal for oppressive measures when the professors of the new faith had, by turbulent defiance of the laws, brought upon them the suspicions of the populace, outraged by public insults offered to their deities. Gibbon quotes the number of Christians on whom capital punishment was inflicted for their religious opinions as under two thousand over the whole area of the Empire, during the period covered by what is described as the Ten Persecutions. Nor does he seek to evade the melancholy truth which forces itself upon the mind of the impartial historian-" even admitting all that history has recorded, or devotion feigned, on the subject of martyrdoms, it must still be acknowledged that the Christians, in the course of their intestine dissensions, have inflicted far greater severities on each other than they experienced from the zeal of infidels."

The Church was soon indeed to exhibit the spectacle of a house divided against itself. While the Eastern Empire was struggling in the throes of the Arian controversy, Africa became the theatre of a peculiarly bitter feud between orthodoxy and heresy. The fact that Eusebius of Cæsarea was a supporter of Arius indicates nothing but a slight similarity between his views and those of the Jonatist sectarians. Their quarrel with their opponents in the African Church was chiefly a 
-

.

$$
\text { . }
$$




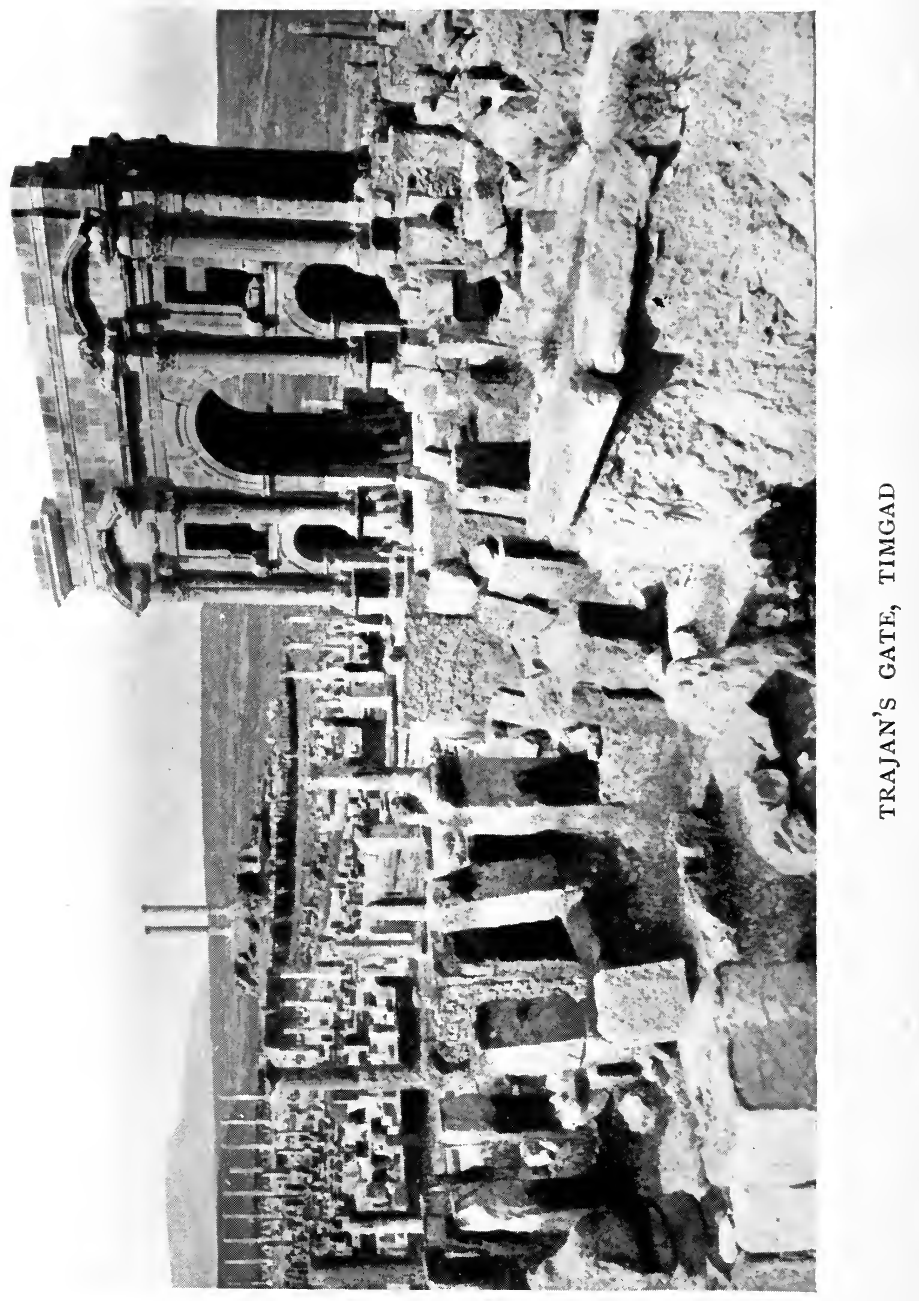


dispute on principles of sacerdotal government. But however trivial the cause, nothing in secular history has ever surpassed the fury of the fray. As Bishop of Hippo, St. Augustine threatened the followers of Donatus with all the penalties of the Church militant. But his denunciations only served to inflame his adversaries, and the ranks of the Donatists were swelled by a multitude of fanatics who adopted the title of Circumcellions, and who furiously resented the exile of their bishops and the demolition of their places of worship. These bands of ignorant peasants from the mountains of Numidia displayed all the stigmata of a fanaticism which bordered on insanity. Fervently attached to the teachings of Donatus, they spread terror over the whole country, setting an example which their enemies were not slow to follow. Well might the holy Gregory Nazianzen lament that the primitive Church of Christ had been converted by internal discord into the image of a nocturnal tempest taking place in hell.

But these religious animosities were for a time lost sight of in difficulties of a political character which convulsed Numidia. The injustice and cruelty that disgraced the reign of the Governor, Count Romanus, had brought the inhabitants to the point of revolt. They/ were encouraged thereto by the son of a powerful Berber prince who had become a vassal of Rome. Firmus 
entirely lacked, however, the genius of the liberator, and his undisciplined bands were ultimately put to flight by Theodosius, who was torn from the conquest of Britain to suppress the rebellion in Mauretania, as Roman Africa was called. After the death of Firmus, Theodosius - the brave and generous Theodosius-speedily reduced Africa to submission, a triumph which was, however, as little appreciated at the court of Valentinian as his other victories. The Empire of the Cæsars was at that time in the agony of disintegration, and the confusion which accompanied the sundering of West and East favoured the designs of two other usurpers. Gildo, the brother of Firmus, and Heraclian, Count of Africa, both sought, though unsuccessfully, to detach the obstreperous dependency which they governed from the crumbling ruins of Rome.

Far different both in temper and capacity was the next adventurer who clutched at the granary of the Empire. Even judged by modern standards, Genseric the Vandal was an impressive personality who united the temerity of a warrior with the craft of a diplomatist. Whether these qualities would have ultimately led him to the conquest of Africa, had not the folly of Count Boniface opened its gates to him, remains one of the problems of history. Deceived by his brother Ætius, who had gained the confidence of the Empress Placidia 


\section{PROVINCE OF MAURETANIA 5I}

Boniface tried when too late to expel Genseric and the savage hordes he had invited. After sustaining one defeat he retired with a remnant of his army to Hippo, where the venerable St. Augustine lay dying after having witnessed the rigorous suppression of the Donatist schismatics by the Emperor Honorius, whose intervention had been solicited by the orthodox party in the Church.

Indeed the success of Vandal arms in Mauretania-for Carthage was temporarily regained for Rome by the repentant Boniface-was due as much to the cruelties perpetrated by the Catholics as to the ambition of Genseric. The hunted Donatists hailed the ruthless barbarian, who was an ardent follower of Arius, as their saviour. Nor were their hopes deceived, for Genseric was as opposed to the orthodox communion as were the Numidians themselves. Thus, in the words of the historian Gibbon: "The wanton outrages against the churches and the clergy of which the Vandals were accused may fairly be imputed to the fanaticism of their allies; and the intolerant spirit which disgraced the triumph of Christianity, contributed to the loss of the most important provinces of the West." 1)ath released St. Augustine in his beleaguered bishopric from witnessing the operation of the lex talionis which at that period indiscriminately regulated the conduct of all followers of the gentle Jesus of Nazareth.

E 2 
But the difficulty of governing the turbulent elements of his newly acquired kingdom seemed to dismay even the dauntless Genseric; for after subduing Carthage, eight years later, he concluded a peace by which he recognized the suzerainty of the Western Emperor over the three Mauretanias. This treaty was, however, merely a device for gaining time to strengthen his resources, and fifteen years later Genseric and his army were at the gate of Rome, conveyed thither in ships built from the forests of the Atlas Mountains.

The death of Genseric did not occur till he had assisted not only at the fall of the Western Empire, but at the defeat of the spasmodic efforts made by the rulers of Constantinople to rescue Africa from its oppressors. But as time went on his cohorts, gradually transformed into colonists, had in great measure lost their warlike propensities. With the language and culture of Rome which they imbibed from the conquered population of Mauretania, they acquired also enervating habits of ease and profligacy. The successors of Genseric inherited just enough of his martial spirit to strike terror into the religious foes of their own household, orthodox or schismatic, as the case might be. The Arian Hunneric seems to have avenged upon the Carthaginian Catholics the blood of those Numidian heretics slain in the day of Donatus. Ecclesiastical historians of this period-and there 


\section{PROVINCE OF MAURETANIA}

are few others-have left heartrending descriptions of the torments inflicted by Hunneric and his nephews upon the adherents of the orthodox religion. Their chronicles are redolent of miracles, and compiled more with the object of demonstrating the favour accorded to them by the Almighty than of furnishing a veracious record of events. The creed, falsely attributed to Athanasius, is probably the work of some unscrupulous divine of the African school of this epoch.

One of the most characteristic miracles is supfosed to have occurred in the little maritime town of Tipaza, whose orthodoxy had withstood both the frenzy of the Donatists and the speciousness of the Arian doctors. Its faithful congregation never wavered even before the wrath of Hunneric, who resolved to take terrible vengeance, when his appointed bishop found his prospective flock determined to abandon the town rather than accept his guidance. An emissary from the seat of government at Carthage followed on the heels of the bishop, and assembling the whole community in the Forum, he ordered the amputation of their tongues and right hands as a punishment of their contumacy. But according to Victor, an orthodox prelate writing two centuries later, the direct intervention of Providence defeated the object of this crime. The confessors of Tipaza continued to preach their form of doctrine as well without 
tongues as with them. So great was the fame of this miracle that the Emperor Zeno requested Restitutus and his companions to come to Constantinople. In this instance the account of the saintly Victor is confirmed-or repeated-by Æneas of Gaza, the neo-Platonician philosopher, as well as by Marcellinus the historian who lived within the same century.

Some legends, whether their source be religious or secular, have power to charm even the most incredulous. The miracle of the mutilated preachers of Tipaza certainly inspired my determination to visit that little spot, whose ruins nestle under the shadow of the Chenoua. Although Tipaza is less than forty-five miles from Algiers, the only way to visit it is by motor car, unless one is prepared to spend most of the day on the wretched railway line that goes as far as Castiglione, where an antediluvian diligence takes three hours more to cover the remaining fifteen miles. The coast-road passes through the rich vineyards of the Sahel, and at times sweeps along the very edge of the sea. The colour of that sea will remain in my memory for ever. Once only -at the mouth of the Tagus-have I seen the equal of its hyacinthine depths, intense, unfathomable, under that scorching July sun. Tipaza of to-day consists of a farmhouse or two and a bright little inn. But its fields and its gardens are full of 
relics-here an archway-there a chipped amphora. Two or three beautiful sarcophagi, casually discovered in the pursuit of husbandry, display their processions of wayfarers and prancing steeds under a canopy of summer leaves. In one of the green alleys of the Propriété 'Trémaux you come suddenly upon a ruined fountain, and farther on, concentric rings of stone, once the stadium of a theatre. Bearing westward you reach an eminence where, overlooking the sea, two arches still stand erect amid broken and recumbent columns. Here was the great Basilica with its nine naves, which perchance resounded to the miraculous voices of the persecuted Catholics. Traces of its mosaic pavement are still visible beneath the riotous lentiscus and the silver branches of absinthe bushes. Away on the Eastern shore are the ruins of St. Salsa's Church, more imposing if less picturesque, and the grey disorder of an ancient cemetery. I wondered if the sea that watched St. Salsa die, a virgin and a martyr, was as infinitely and passionately blue, or whether the holy inhabitants of Tipaza were too busy resisting heresy to observe the beauty of God's earth.

To return to the last hundred years which saw the end of the Christian dispensation in Africa. Although the dynasty of Genseric seemed firmly established upon the throne, the Eastern Empire had never entirely relinquished the hope of adding 


\section{ASPECTS OF ALGERIA}

this lost province to their Oriental possessions. Various pusillanimous attempts to do so had failed till the possibility fired the ambition of Justinian, who succeeded to the imperial purple in A.D. 535. Good fortune supplied him with an effective instrument for the realization of this purpose in Belisarius, who had already risen from the humble estate of a Thracian peasant to that of a guard in the Palace of Constantinople. When the fleet was ready for the invasion of Africa it was to Belisarius that Justinian confided the supreme command. Subsequent events proved the wisdom of this choice, for the celerity and humaneness with which he carried out the subjugation of Mauretania were worthy of Scipio and the military traditions of Rome in her prime. Gelimer, the last of the Vandal sovereigns, had succeeded, by the treacherous deposition of Hilderic, to a kingdom disintegrated as much by the poison of religious strife as by the excesses which had extinguished the strenuous qualities of the Barbarians. Defeated at Carthage, Gelimer fled to the Numidian desert till, hunted and despairing, he eventually surrendered to Belisarius, and embarked with him for Constantinople three short months from the day of the invader's landing at Cape Vada.

To complete his conquest the Roman general left behind him the eunuch Solomon, who led his 
victorious legions to the confines of the Sahara. Nor did he rest till he had reclaimed Lambæsis and the Aures Mountains from the Berbers, driven thither, as I explained in the preceding chapter, by the encroachments of the Vandals. He was not, however, destined to maintain his authority over the reconquered province. The wise counsels of Belisarius found no favour with the rapacious Justinian, whose sole idea was to wring an excessive tribute from the half-vanquished Africans. Resentment soon wiped out the memory of their sworn allegiance, and, encouraged by the Arian Christians, who intrigued incessantly for the rehabilitation of their sect, the Berbers again raised the standard of revolt. In the sanguinary conflict that devastated Mauretania the rebels were led by a private soldier named Stoza, who possessed in a high degree the qualities of a military commander. At Tibeste, now Tebessa, Solomon and his whole army were annihilated, and thereafter the once fruitful land relapsed into a condition of barbarism.

For an impartial account of the events of this period we can turn to the chronicle of Procopius, the faithful henchman of Belisarius, who followed him in all his expeditions. He records his admiration, on first landing in Africa, for the evident prosperity of the cities and the fertility of the cultivated agricultural districts. During the 
twenty years' war prosecuted by the government of Justinian more than five millions of the inhabitants were slain, the towns were laid in ruins and desolation overspread the country. According to Procopius, an eye-witness quite worthy of credence, the entire nation of the Vandals was destroyed. And such was the misery of the survivors that they welcomed the advent of the Saracens, much as their ancestors had welcomed Genseric, and for the same reason.

Only the unconquerable Berbers, from the refuge of their mountain caves, offered a disorderly resistance to the new invaders from the East-a resistance less protracted, however, than that which repulsed the Byzantine army. Inspired by a prophetess called Kahina, these savages accomplished the destruction of the crops and fruit trees to prevent their falling into the hands of their steadily advancing enemies. It is improbable, however, that much remained to destroy. The furious onslaughts of the Christian sectaries upon each other's lives and property, the rapine and pillage of Vandal hordes and Roman legions in their successive wars of extermination, had already achieved that ruin so erroneously attributed by the modern French colonist in Algeria to the Arabs. 


\section{CHAPTER IV}

\section{ISLAM PAST AND FUTURE}

IT is not through the triumphant azure of an Algerian noon that one may aspire to come near to that elusive incommensurable thing-the spirit of Islam. The mere desire to do so rarely, I believe, occurs to the average traveller, who is wont to regard it as something mysteriously unclean. Even the elect, who study history with the eye of the philosopher and beauty with the eye of the artist, are apt to find that in this quest neither knowledge nor sympathy will avail them much. The Moslem soul, like the mirage of their desert, recedes as one approaches, jealous of its peace, threatened already in all the ways of men by the encroaching tide of Western civilization. But in order to realize the nature and consequence of the impact of modern scientific ideas upon " the living theism of Islam," to use Sir William Muir's phrase, one must realize to some extent what the character of that religion was in the earlier stages of its evolution.

Islam, as taught by Mohammed, as expressed in the impassioned imagery of the Koran, was above 
all a positive religion, based upon the unalterable conviction of the unity and the omnipotence of God. Its master doctrine, Judaic in its origin, was the simple formula, "There is no deity but God, and Mohammed is His messenger," and that confession, which was, and still is, in itself sufficient to secure admission into the congregation of the faithful, necessarily implied the absolute dependence of man on his all-powerful Divinity. On the material as well as the spiritual plane, the God of the Arabian Prophet was sole and supreme Lawgiver. Thus, coincidental with the religious dogma, there grew up a system of social and political regulations which partook of its divine character. Although very few of these enactments are to be found in the Koran, the sanctity of the secular law was affirmed two centuries later in the Sunna, or Traditions, and still governs the existence of the majority of the three hundred million Moslems scattered over the face of the earth.

In spite of the fact that every chapter of the Koran begins "In the name of God, the Compassionate, the Merciful," the warlike desert tribes who were among Mohammed's earliest disciples were more imbued with the might and majesty of their deity than with his mercy. Thus the bones of the Prophet had scarce crumbled into dust when Islam began its career of conquest. His descendants eventually discarded the simple life 
of the Apostle of God. The Caliphate, first established in Medina and afterwards Damascus as its armies overflowed Syria and Egypt, was ultimately enthroned in Constantinople when the crescent waved over the ruins of the decadent Byzantine Empire, incapable of any sustained resistance. But before the end of the seventh century the Arabs had rendered themselves masters of the North African coast, and had imposed their faith on the romanized Berbers who then formed the majority of the scanty population of the Moghreb. This name designated a territory considerably surpassing in extent the Mauretania of the Romans.

But the triumph of its hosts over the infidel failed to bring peace to Islam. The bitter animosity which arose between the successors of the Prophet was soon crystallized in the rival dynasties which fought desperately for temporal and spiritual supremacy over the rest of the Moslem world. Kharedjites struggled against Fatimites; Abbassides against Ommeyades; and as some of these factions represented a different interpretation of the Traditions, the contest for the throne of the Caliphs became at the same time a war of orthodoxy against heresy. The schism between the Sunni and the Shiah sectarians was never healed, though it became localized according to the varying fortune of its supporters. In course of time the upholders 
of the Sunni tradition spread their tenets over practically the whole of the Western Empire, and after the conversion of the Pathans and the Moguls carried the conquering crescent through Persia and India to the Great Wall of China, where its propaganda is almost as active to-day as it was twelve centuries ago. On the other hand, the followers of the murdered Hassan and Hosein seem to have been less combative than their rivals, and although Shah Ismail, the founder of the Sufi dynasty, made Shiaism the state religion of Persia, he did not succeed in establishing it beyond the boundaries of his empire. There are signs to-day that the age-long feud between the two traditions will disappear as Islam becomes consolidated through the influence of pressure from without.

It came to pass, however, that the trifling initial difference between Islam as it was taught in Africa and in Asia became accentuated as time went on. In the West, the religion of Mohammed remained entirely untouched either by the emasculated Christianity or the lingering fetishism which it roughly supplanted. But in the East it came into contact with an ancient civilization still in flower, impregnated with mysticism, philosophic in Persia, pantheistic in the farther Orient. Subjected to these influences, the doctrines of Islam began to lose something of their primitive rigidity. While continuing to respect the letter of the Koranic law, 
Moslem doctors in the East came to discover in it an esoteric significance, and to adopt in its interpretation the dialectic subtleties of the Sufi philosophers. Side by side with this slow infiltration, fortifying it, was the inevitable influence of locality. Although Moslems in India and in China continued to make the pilgrimage to Mecca as ordained by the Prophet, their hostility to Buddhistic feasts and to the cult of the Ancestors died out through centuries of contiguity. Insensibly their converts came to worship the terrific Islamic deity and the gentle household gods of Shintoism at the same altar, with but superficially modified rites.

Another phenomenon, comparable to that which the Church of Rome repelled under the name of "Cisalpinism," ultimately completed the detachment of Asiatic Islamism from the dogmatic theocracy of the West. This was the gradual weakening of canonical authority vested hitherto in the Ulemas, an ecclesiastical body which had become, under the heel of the Turkish domination, mere functionaries of state devoid of real spiritual influence. Time was ripe for the rise of a new authority exclusively religious in character, which should infuse fresh life into the old Moslem faith, and this renascence was accomplished through the development of a mystic cult hagiological in character. There arose in Islam a race of fanatical ascetics like the monks of medieval Italy, but 
claiming supernatural powers as intermediaries between God and man. Many of these teachers or saints founded confraternities, somewhat similar to the Buddhist Orders of Yoga, and from these centres, or Zaouiya, emanated an active propaganda. Of these religious Orders, one of the earliest and most remarkable was the sect of the $W$ ahabis, austere visionaries who aspired to bring Islam back to its primitive purity, and who established themselves in the Yemen about I746. But it was not till a century later that the movement reached North Africa, when the Sheikh-el-Senoussi, expelled from Mecca by the jealousy of the Ulemas, founded, in the latter half of the nineteenth century, a Zaouiya near the confines of Tripoli, which developed into a veritable theocratic state. In Algeria itself the Order of the Tidjania soon grew extremely powerful, and exercised, even after the death of $\mathrm{Si}$ Ahmed ben Mohammed el Tidjani in 1853 , an influence as much political as religious, which hampered the French in their early dealings with the Arabs. The founders of these sects were regarded by the nomad populations of the desert as Marabouts, or prophets directly inspired by Allah. Of such, without doubt, was the Mahdi, whose career, beginning as a mogaddem of the Kadriya Order, was cut short at Omdurman. Of such, also, was the Bab in Persia; ecstatics both of them, who believed in their 


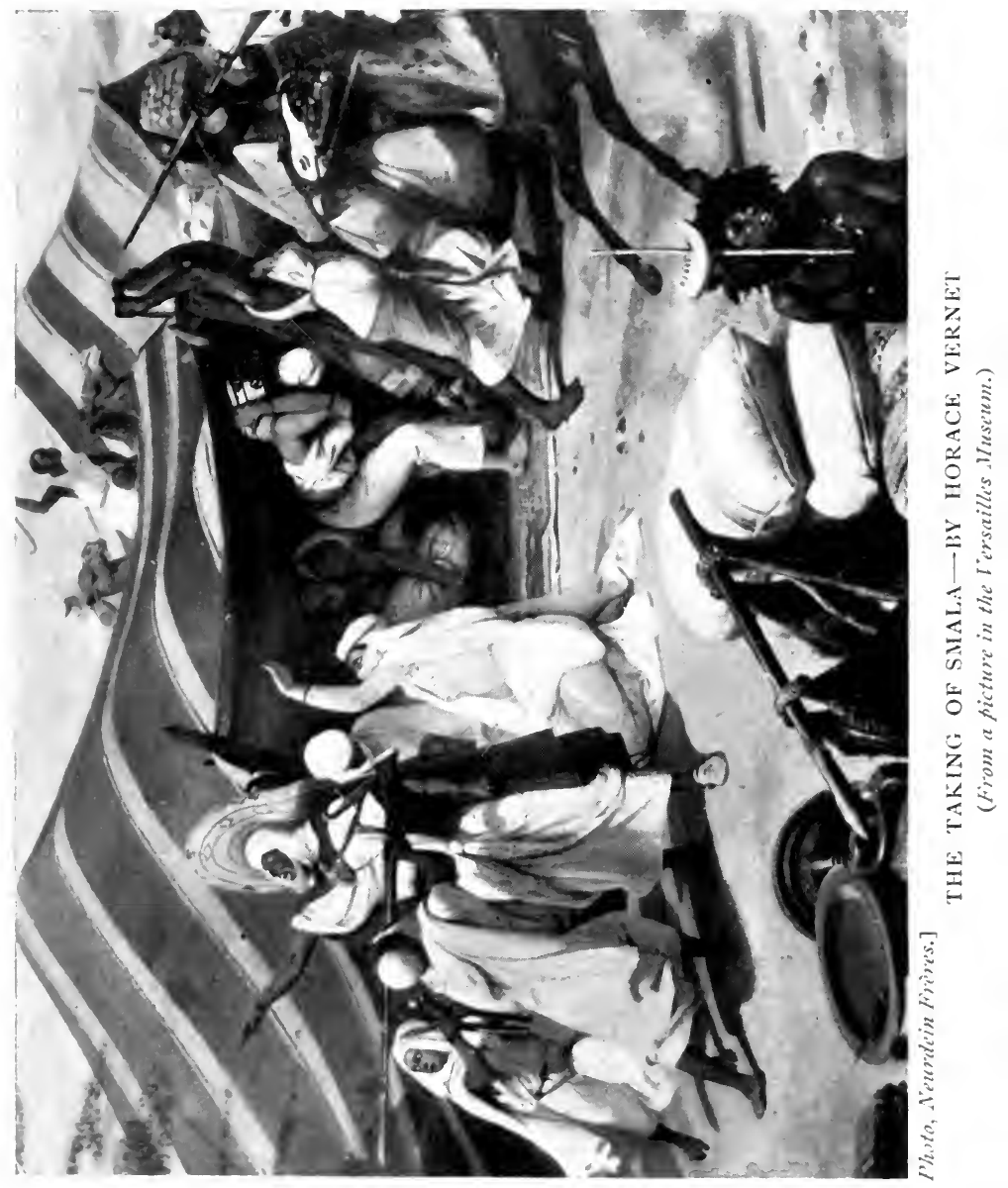



mission to regenerate Islam, although the latter was not affiliated to any of the confraternities.

A special ritual of prayers and mystical dances was adopted by each Order. The latter have been rendered familiar to travellers by the Dervishes in Egypt, who are, for the most part, members of the Khelouatiya sect. The object of these exercises is to induce a condition of hypnosis, in which state the soul is supposed to attain " the annihilation of its individuality through absorption in the essence of God." . This is the language of all mystics, of the Sufi philosopher as well as of St. John of the Cross. It appealed with irresistible force to the ignorant and imaginative Arab of the Yemen and the Sahara. Thousands enrolled themselves as Khouans, or lay-members of the different confraternities, which rapidly increased in numbers and began to assume the character of secret societies, equally intent on propagating the faith of Mohammed and on offering every possible resistance to infidel aggression in Africa. Had any leader arisen capable of uniting and organizing the scattered elements of this reactionary force, there is little doubt that European civilization would have been driven back across the Mediterranean Sea. But although the most slavish obedience was exacted by the Sheikh-el-Triqa, or head of each Order, from his Khouans (a docility equal to that of " a corpse in the hands of them who dress 
the dead"), none ever attempted to impose his authority over sister Orders or even over Zaouiya of the same rite situated in other countries. This absence of all cohesion among the desert confraternities, diminished their ascendency over the Moslem consciousness as a whole, especially when their founders were succeeded by men of inferior calibre. The famous formula of the Senoussiya, "Turk and Christian, I will break them with one blow," seems to have lost its sting, though it may well be that the reprobation, so violently expressed in Tripoli against the Young Turk party in 1908 springs from a recrudescence of the mistrust which formerly reigned between Djerboub and the Khalifat. If so, it is but an explosion of religious sentiment that will expire as quickly as it arose. $\mathrm{Si}$ Mohammed ben Ali el Senoussi probably cherished the hope of eventually preaching the Djehad, or Holy War; but his refusal to lend the weight of his influence to the Mahdi of Khartoum is evidence that the hope was too frail to grasp. He was too far-sighted not to realize the power of that Europe which he execrated and dared not openly defy. Where he hesitated none would advance, for of all the confraternities the Senoussiya were the most powerful because the most highly organized. Nor did the convulsions of the Kadriya or the howling of the Refaiya ever form part of its ritual. Its teaching may not have conformed to the orthodoxy 


\section{ISLAM PAST AND FUTURE}

of the Ulemas, but it was free from the excesses of hysterical fanaticism. Of the eighteen or twenty Orders which still count adherents in Islam, only three or four retain a vestige of their former influence. As far as Africa is concerned, their members limit their activity to a propaganda which has lost its political, while conserving its spiritual, character.

Meanwhile Islam, as it is, is commending itself more and more to the negro populations of Central and Western Africa. In an article which recently appeared in the Revue $d u$ Monde Musulman, founded by that distinguished Orientalist, Professor Le Chatelier, it is estimated that at least a quarter of the I I,500,000 inhabitants of that large section of West Africa within the French sphere of influence have already been converted to Islam. The great tribes of Peules and Songhais, many of the Mandés, all offshoots of the vast Semitic family, have already renounced a degraded form of fetishism in favour of the Crescent. It would seem that its missionaries meet with greater success in these latitudes than those of the Cross. To the savage its tenets are more acceptable and more comprehensible than those of Christianity. The Moslem adept, Kadriya or Tidjania, as the case may befor the islamization of the negro races is chiefly the work of these two confraternities-offers to his converts a religion which is positive, untinged 
by altruism, and which does not seek to alter his attitude towards woman, who remains, as she has always been, his captive. But, in spite of this flaw, Islam has done excellent work as a civilizing medium in Senegal and the Niger territory, particularly in forbidding the consumption of intoxicating liquors by its converts, and in teaching them the Arab language. On the heels of the mogaddem, or missionary, comes the trader, and so the empire of Islam grows and will grow southward and eastward as it recedes from Europe. Whatever may be its future in the Occident, it is very improbable that anything will cause it to relax its hold on those savage tribes who are, with its assistance, far more than ours, just emerging from the night of barbarism. In his admirable work, L'Islam dans l'Afrique occidentale, M. Le Chatelier expresses his opinion that the portion of the continent peopled by negroes will become in process of time entirely Mohammedan, and the testimony of British administrators in Africa unanimously supports that prediction.

With the object of combating this propaganda, M. Le Chatelier urges upon his compatriots the necessity of making some attempt to substitute the French for the Arab language as a medium of commerce in Equatorial Africa. He advocates the use of French in all intercourse between the negro chiefs and the administration, and the estab- 
lishment of schools and of interpreters whose chief task it should be to demonstrate to their pupils the advantages that would accrue from a knowledge of the French tongue. If this policy were intelligently carried out, it would doubtless restrict the diffusion of Islamic influence and the use of its language. But before this could be accomplished it would be necessary to create a staff of negro teachers sufficiently conversant with French to be able to impart it. The intervention of the Tholba, or Arab schoolmaster, would be as fatal to the scheme as the importation of instructors from France. To impress the negro it is essential to win his confidence, and that can only be done by a propagandist who shares his life and who is, as far as habit and appearance go, nearer his own level than any European could possibly be.

This quickening of the spirit of Islam has, moreover, been neutralized by other currents that have reached it through contact with the civilized world. In countries such as Egypt and Algeria, where Europe is attempting to graft her ideas, her culture and her political institutions upon Mohammedan society, one of the results has been a weakening of religious faith. Education has inevitably brought scepticism in its train. Western science is slowly but surely eating away that uncompromising belief in the teaching of the Prophet wherein lay the strength of Islam. Invulnerable, it was 
mighty and eternal. But to-day in the Algerian student, as in the Young Turk and the Egyptian Pasha, the adoption of our habit of thought has bred indifference to the creed of their ancestors, while it has developed-I had almost said created -a spirit of nationality which the Moslem races have never known before.

In Algeria the operation of this double and complex phenomenon is modified by local conditions. Unlike Egypt, where the fellaheen remain undisturbed in their immemorial superstition, it is the lower classes of the native population of Algeria which have been the most sensibly affected by the introduction of Occidental civilization. The Arab aristocracy, represented by the great tribal chiefs, had been driven out of the urban districts by the Turks long before the French landed at Sidi Ferruch. In their desert habitations they remained, until quite recently, inaccessible to the new ideas, whereas their people were forced into continual intercourse with their conquerors. On account, however, of the parsimony which has hitherto characterized the efforts of the latter to educate their Moslem subjects, it is only in the towns that a tendency towards a more liberal interpretation of Islamic law is visible.

When the process of transforming these Orientals is complete-if ever it does approach completionhow much of its age-long vitality will " the living 
theism of Islam " retain? Is it possible to purge away the dross which has accumulated in the course of centuries round the pure gold of the doctrine that fell from the lips of Mohammed? Many of these accretions have engendered abuses, such as the claustration of women-nowhere ordained in the Koran-which are mainly responsible for the backward condition of the Islamic races. Why should they not be abolished, together with all those social and political regulations, well adapted to uncivilized communities of the seventh century, but whose utility is now outworn? The vexed question whether Islam is or is not susceptible of reform, so that, like Christianity, it may meet the needs and aspirations of the twentieth century, has given rise to poignant controversy both within and without the fold. Moslems such as Syed Ameer Ali in India, as the Sheikh Mohammed Abdou in Egypt, as Ismael Hamet in Algeria, and others less known to fame, have consecrated their energies to the task of proving that Islam is not essentially inimical to progress.

In the opinion of many Christian critics, of whom Lord Cromer is one, the evolution of Islam depends primarily on the emancipation of those shrouded figures which still gaze at the world through the shutters of the harem. Writing for Egyptians, he asserts that when the harem ceases to be a synonym for ignorance and mental debility, 
Egypt will then be fit to govern herself; and her sons, brought up by educated mothers, will be content with one wife, "for self-respect and polygamy are incompatible." The error that Mohammed was responsible for the practice of polygamy is so engrained in the Western mind that we are in the habit of forgetting how the Christian Church regarded the sex until quite modern times. It was Tertullian, whom Africa is proud to acknowledge as her son, who described women as "the devil's gateway, the unsealer of the forbidden tree, the deserter of the divine law, and the destroyer of God's image-man." According to the historian Lecky, Saint Chrysostom, not to be outdone in charity, writes of woman as " a necessary evil, a natural temptation, a desirable calamity, a domestic peril, a deadly fascination, a painted ill," and in so describing half the human race he interpreted the general opinion of the early Church. That these views have ceased to regulate the destiny and the dress of woman is due to the fact that Europe has liberated itself from the teaching of the Fathers of its Church, whereas Islam has not yet done so.

At the period when the Arabian prophet began to preach, the seclusion of women was practically universal. The woman of Mago-Zoroastrian Persia was a hidden slave of the caprice of man. The wives and daughters of the Ionian Greeks 
were confined in the gynecy, and as jealously guarded from the public gaze as any Asiatic. Mohammed, in limiting the ruthless promiscuity which prevailed in his own country and elsewhere, rendered great service to women, and invariably inculcated respect both for their persons and their property. Those of his own household circulated freely among the Faithful, eating and conversing with them; and after his death his last wife, Ayesha, commanded her own troops at the famous "Battle of the Camel," and took a leading part in the revolt against Ali and his followers. Enlightened Moslems are, moreover, as convinced to-day as any European of the importance of extending the advantages of education to their womenkind. In the upper classes, at least, polygamy is fast dying out, chiefly from motives of economy. Many Turkish women have proved their sympathy with the new régime by casting aside their veils, and those that are still worn by women of the Khedivial family in Egypt conceal less of the features than the veils which adorn the hats of their Christian sisters. But that remnant is, after all, a symbol of servitude, which the younger generation finds every day more irksome and unnecessary.

Those who possess some personal knowledge of the Moslem woman and her embryonic soul are, however, convinced of the wisdom of " making haste slowly" in the work of her development. 
If her seclusion deprives her of some privileges which Occidental women enjoy, she escapes thereby much of the responsibility which is the price of freedom. In any case she should only be delivered by degrees from the bondage which centuries have imposed upon her. To throw open indiscriminately the doors of the harem would merely give the average Oriental opportunity to misuse her liberty. Let her retain a little longer the closed carriage and the wisp of white muslin. Ultimately the assimilation of Western culture will enable her to grow, it may be at the sacrifice of her peace, "a reasonable soul with human flesh subsisting."

Slavery, again, is no more characteristic of Islam than polygamy. Mohammed's laws protected the slave as they protected women, in an era where slavery was not only practised by every nation, but was an economical necessity. Under modern conditions it has become not only superfluous, but detestable, though the horror which the idea of slavery inspires is of extremely recent date. Not much more than a century has elapsed since half of Christian America embarked upon a long and bloody war to preserve the ancient custom of enslaving the negro. And the atrocities recently perpetrated by Belgian officials in the Congo entirely deprive us of the right to regard slavery as peculiar to Moslem civilization, either past or present.

It was, in fact, neither their attitude towards 
women nor towards serfs which arrested that civilization, "whose unexampled intellectual activity," to use the words of Humboldt, "marks a distinct epoch in the history of the world." Christian historians have recorded, usually with justice, occasionally with enthusiasm, the debt that humanity owes to Islam which, as Johnson admirably expresses it, "first kindled its chosen hearts to worldconquest, then gathered itself up into a reconstructive force that all the creative light of Greece and Asia might penetrate the heavy gloom of Christian Europe, when Christianity was but the Queen of Night." Not only Cordova, but Tlemcen, Cairo, Bagdad and Samarcand became, under the rule of the Moslems, sumptuous centres of learning, whence radiated, for a period of five centuries, the beneficent influence of wisdom and progress. Nor did this influence wholly expire when the armies of Ferdinand and Isabella converted into a barren waste the Spain which the Moslems had made into a smiling garden. The principles of freedom and culture propagated by Islam in its golden age communicated their vitality to the rest of Europe, just then awakening from the torpor of the dark ages. Descartes, Hobbes and Locke were the lineal descendants of Avenpace and Averroes.

The causes that contributed to the downfall of Islam were multiple as well as complex. In the East, the eruption of the Moguls, even more bar- 
barous than the Goths and Vandals, wiped out, as would a cataclysm of Nature, everything with which it came in contact. In the West the old tribal rivalries, the spirit of the clan, survived even after the religion of the Prophet had apparently welded the Arabs into a nation. Undisciplined and passionately individualistic, they could not bury their family feuds even when arrayed against a common enemy. Divided they fell before Charles Martel, and the same causes lost them Constantinople, and thereafter Andalusia. Intensifying the political differences of Fatimites and Ommeyades was the protracted strife of sect against sect. The innumerable variations of orthodoxy and heterodoxy slew the peace and prosperity of Islam as it did of Christianity. Syed Ameer Ali, in his remarkable book, The Spirit of Islam, thus draws a parallel: "Islam had to pass through the same throes as Christianity. From the beginning of the second to the end of the ninth century there was an unceasing struggle in Christianity with the ancient cults, which were appearing in diversified character throughout the wide area in which the religion of Jesus was professed. After this struggle was over a deadly pall settled over Christendom; orthodoxy had succeeded in crushing not only the revolutionary Montanists, the Manichæan Paulicians, but also the rationalistic Arians. Ecclesiasticism and orthodoxy, convertible terms, 
held in bondage the mind of man until the Reformation. Islam had to pass through the same ordeal, but its reformation is only just commencing."

Is it possible that the Church of Mohammed will follow the example of the Church of Christ and arise from the ashes of obscurantism to new life? Syed Ameer Ali believes that it will. $\mathrm{He}$ continues: "In the Western world the Reformation was ushered in by the Renascence, and the progress of Europe commenced when it threw off the shackles of ecclesiasticism. In Islam, also, enlightenment must precede reform; and before there can be a renovation of religious life, the mind must first escape from the bondage which centuries of literal interpretation and the doctrine of ' conformity' have imposed upon it. The formalism that does not appeal to the heart of the worshipper must be abandoned; externals must be subordinated to the inner feelings, and the lesson of ethics must be impressed on the plastic mind; then only can we hope for that enthusiasm in the principles of duty taught by the Prophet of Islam." This reformation which Syed Ameer Ali so ardently desires will, he believes, begin when the Moslem finds the courage to recite his prayers in his own tongue. As the Latin language fettered the Christianity of the Middle Ages, so has the Arabic language rendered the sacred books incomprehensible 
to the majority of Moslems. In India, it appears, a movement has already begun which has for its object the supersession of the theological by the vulgar tongue.

For the rest, Syed Ameer Ali has faith in a regenerated Islam which will find a deeper meaning in the precepts of the Koran beneath the husk of a dead letter. His conviction of a divine immanence, transcending and yet not abrogating dogma, reminds one of the metaphysics of Professor Caird. There is, in fact, little appreciable difference between Islamism as understood by Syed Ameer Ali and the half-mystical, half-scientific Deism which the works of $M$. Bergson has recently made so popular in England. To the intellectual Moslem, as to his Christian counterpart, such a creed is well adapted; but what appeal can it ever make to the untutored masses of either faith? To revivify a religion still encumbered with the dust of ages, to defy a priesthood retrograde yet wielding immense power, is a herculean task. It is easier-incomparably easier - to educate the Moslem outside his religion than with it and through it.

Among those critics who are more inclined to believe in a new material expansion for Islam than in its spiritual resurrection M. Raymond Aynard must be counted. In his recently published volume, entitled L'Oeuvre française en Algerie, he accuses the religion of the Prophet of having 
participated in all the great transformations of social life without ever breathing the spirit that has animated them. The Islam which M. Aynard represents has contented itself in keeping a disdainful watch on the growth of the human soul, with its alternating dreams of social brotherhood and intellectual liberty. It has found consolation for the slow shrinking of its empire over the enlightened populations of Europe in its increasing authority over the negro millions in Africa. An image borrowed from Dante serves to illustrate his point: "Situated between a marvellous efflorescence of religious sentiment and the great development of rationalism characteristic of our time, the revelation of Mohammed projects itself, not towards the future, but into a past anterior to Christ Himself. The sombre poet who in his Divine Comedy has represented the Prophet wandering with his decapitated skull turned backwards upon his shoulders, unconsciously, and by means of an incomparable plastic symbol, determined the world-position of this successor of Moses."

In summing up this antagonistic analysis of Islam's past influence and probable destiny $M$. Aynard writes: "It may be that Islam will again found great empires, even if it never inspires great virtues. It may possibly astonish the world by its capacity for adaptation to new conditions. It 
may even array itself one day against a decadent Europe, profiting by its lessons and surpassing its energy. But it will never possess the socially regenerative power which belongs to the Christian idea. Nor will Islam ever create anything, for it is above all based upon a negation, and from that fact has sprung both its strength and its sterility."

Time alone will show for the Mohammedan as well as for the Christian Church how far the liberated spirit of man can retain the old faith in any form of dogmatic theology. Some years ago Ernest Renan gave a lecture at the Sorbonne in which he threw doubt upon this possibility. In his delicate philosophy an ibis-path is indicated between the optimism of Syed Ameer Ali and the pessimism of M. Aynard. In so far as his words referred to Islam, the Sheikh Jamal-ed-Din, one of the earliest and most influential reformers who was then in Paris, took occasion to combat Renan's contention. The reply of the author of Averroes and Averroism is so characteristic that I am tempted to quote a few phrases of it. "One aspect," he confessed, " in which I have appeared unjust to the Sheikh, is that I have not sufficiently developed the idea that all revealed religion is forced to show hostility to positive science; and that in this respect Christianity has no reason to boast over the Mohammedan faith. About that there can be no doubt. Galileo was not more 


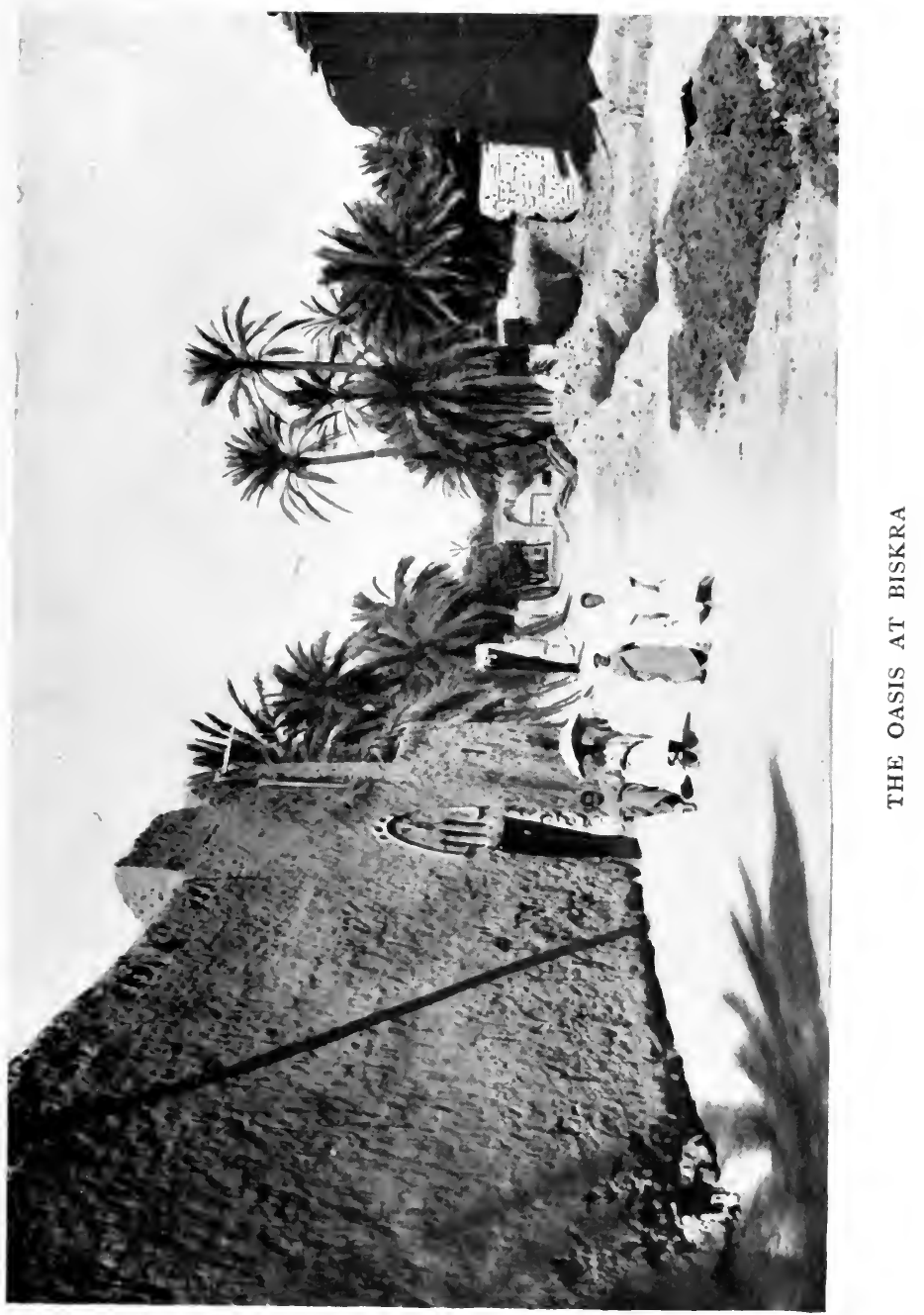



kindly treated by Catholicism than Averroes was by his co-religionists. Galileo found truth in a Catholic country despite Catholicism, as Averroes nobly philosophized in a Moslem country despite Islam. I have said sufficiently often to preclude any necessity for repeating it, that the human mind must be detached from all supernatural belief if it desires to labour at its own essential task, which is the construction of positive science. This does not imply any violent destruction or hasty rupture. It does not mean that the Christian should forsake Christianity, or that the Moslem should abandon Islam. It means that the enlightened parts of Christendom and Islam should arrive at that state of benevolent indifference in which religious belief becomes inoffensive. This is half accomplished in nearly all Christian countries. Let us hope that the like will be the case for Islam."

Twenty-five years have passed since the famous philosopher expressed that hope, and those years have somewhat modified the spiritual aspirations of our time. The reaction against the scientific scepticism of the latter half of the nineteenth century which the first decade of this century has witnessed has carried us no nearer "benevolent indifference." On the contrary. The effort to discover a logical basis for faith in the secret garden of a man's own soul has never been so sustained, 
nor has what Professor Lowes Dickinson calls "the insatiable hunger for eternity" ever been so keen. And a perusal of those journals which reflect the temper of the educated Mussulman give support to the assumption that Islam and Christianity are indeed evolving along parallel lines. So far the analogy established by Renan holds good. But the "detachment from all supernatural belief" which he desired for the human mind is further off to-day than when he defended his thesis against the Sheikh's criticism. Possibly it will survive by becoming "inoffensive," or rather undogmatic. 


\section{CHAPTER V}

THE ARAB IN ART AND SCIENCE

"IT is a poetry the chief task of which is to paint Life and Nature as they really are, and within its narrow bounds it is magnificent. It is characteristically full of manliness, of vigour, and of a chivalrous spirit doubly striking when compared with the spirit of abject slavery found in some other Asiatic nations. It is wild, vast and monotonous as the yellow seas of its desert solitudes; it is daring and noble, tender and true."

In such words does Professor Palmer, the distinguished translator of the Koran, describe Arab poetry of pre-Islamic days. Before the Prophet was, poetry flourished. The inhabitants of this barren peninsula might almost be said to "lisp in numbers," for the rhythmic quality of their language was as remarkable as its richness in epithet. 'That sonorous Arabic was, in fact, scarcely capable of the severity of prose even when, in the golden age of Islam, an exposition of scientific theory seemed to interdict the use of metre. The Koran itself has a rhythm that makes it almost poetry, and 
the accusation that Mohammed curtailed this universal impulse in his people is, of course, a libel. If poetry ceased to be the unique occupation of the Arabs during his lifetime, the change was due to political circumstances created by the introduction of a new religion. Is not the Prophet's admiration of Antar, the hero and type of Arab chivalry, recorded by the Companions? Did he not describe him as the man whom, above all others, he would like to have known?

It was between the ninth and the eleventh centuries that, encouraged by illustrious patrons, the perfection of poetical form was attained. Haroun-al-Raschid of The Thousand and One Nights, and many of the Ommeyade Caliphs, became for the poets of the Orient what Leo $\mathrm{X}$ was to the art of Italy, and Louis XIV to the literature of France. The conquerors of Islam carried with them not only their invincible sword, but that marvellous Arabic tongue - the only bond of union which tribal instinct never destroyed. From Bagdad to Damascus, and thence to Cordova and Tlemcen, the poets of the Saracens sang, and not in vain. Some idea of the enthusiasm they inspired may be gathered from the strife which the rival merits of two poets aroused in the city of Cordova during the reign of Hakim the Second. Instead of fighting over politics, the inhabitants fought over poetry-Guelphs, one might say, for 


\section{ARABS IN ART AND SCIENCE 85}

the singer of the rose, against the Ghibelline admirers of the singer of the rain.

"Were it not evident," writes the author of the Pilgrimage to Mecca and Medina, "that the spiritualizing of sexuality by sentiment, of propensity by imagination, is universal amongst the highest orders of mankind- 'C'est l'étoffe de la nature que l'imagination a brodée,' says VoltaireI should attribute the origin of love to the influence of Arab poetry and chivalry upon European ideas rather than to medieval Christianity." It is indeed difficult to exaggerate this influence, which was at its zenith just before the First Crusade brought the still untutored mind of Europe into contact with the splendour of the Saracenic civilization. The transformation of Gaul into France, the rescue of the Teutons from their immemorial vandalism, received its initial impulse from the court of the Caliphs. Qualities and phrases, the whole tradition of chivalry, which is now the boast of the Occident, were characteristics of the Arabs long before they were of ours. The Song of Roland was but an echo of Imr-el-Kais which had resounded over the Arabian plain ere ever it awakened the heights of Roncevaux.

The erotic simplicity which is popularly attributed to the entire range of Arab poetry is only true of its lyrics. How should it be otherwise when they were almost invariably addressed to 
women whose average age was from ten to twelve years? As a rule it was the unknown charms of his affianced bride that inspired the Saracen versifier. The flame and danger of illicit passion was more frequently celebrated in the form-rhythmic if not exactly metrical - of the short story. In the case of the Arab woman childhood passed into age with an abruptness unknown in the North. She grew old, but never mature; her amorous sensibility died before it was ripe, and never broke the spell of the visual images created by her lover's lyre.

This dual character of simple sensuousness and infinite complexity is as present in Arab music as in its poetry. The love song is but a plaintive and romantic melody destined to break its wing against the bars of harem windows. But the Noubah is the Oriental symphony, displaying all the subtlety of harmony and structure which we associate with that musical mode. It possesses, moreover, the resource of seven or more keys, whereas the Western composer has to limit his genius to two. The Noubah is usually divided into five or six themes, and was brought into Algeria by the Moors when they were expelled from Spain. But of the fourteen classical models which formerly existed, seven have been irrevocably lost. Some of them were of Syrian origin, and were an inheritance from the "Time of Ignor- 


\section{ARABS IN ART AND SCIENCE}

ance," as the Prophet called the days before his message changed the destinies of his people. The Turks, also, cultivated the symphonic form, but their Noubahs have a martial quality which is entirely absent from the earlier compositions.

Laudable efforts have recently been made in Algeria, both by educated natives and by French lovers of Oriental music, to annotate the six or seven Noubahs of whose harmonies some record is still extant. A society has also been formed with the object of collecting the Gharnata-literally "Music of Granada"-which are in equal danger of being lost when the few accomplished native singers who remain take their melodies with them into the grave. Some of the musical instruments used by the Arab are very similar to ours. The Kamendja is a replica of our violin, while the Snitra is but the parent of the Neapolitan mandoline. The Rebad is a sort of viol, the Rheita a kind of guitar. This latter one can often hear sobbing through the night in the tents of the Sahara. Then the voice of the singer accompanying it seems to mingle with all the unfathomable sounds rolling over the ocean of the desert. Its burden of love and sorrow is first insistent in the ecstatic modulations of the music, then quelled by the spasm of unknown chromatic intervals. It is a music whose whole tonic capacity seems strained in the eternal effort of expressing the inexpressible. 
In the Moorish cafés in Algiers the instrument most in use is the Derbouka. It consists of a simple cylinder of pottery, varying in size, and hooded by a piece of parchment or dried skin.

The legendary origin of Arab music, full-grown when Europe was yet dumb, refers it to the occasion of Satan's expulsion from Paradise. The wind sighing through a skeleton which was hanging on a tree suggested to the exiled Lucifer a means of replacing the songs of the celestial choir. Other legends, celebrating the talents and triumphs of the innumerable singers who thronged the Court of the Caliphs, are legion; but they all testify to the esteem in which both poetry and music were held-an esteem only equalled as regards the latter in Germany of to-day.

I now come to the third form of artistic activity in which the Arabs excelled-a form whose beauty is surer of our appreciation, seeing that it speaks to us in the indestructible language of stone. It is a more intimate expression of Islamic thought than either the poetry or the music of the Saracens, for its evolution followed on the armed propagation of the new faith. Mosques and palaces grew like flowers out of the battlefield. The preexistent styles of Persia and Syria were adopted, and transfigured by the formula of the Prophet as Eastern Asia succumbed to his adherents. In the Western world the artistic impulse of the Arabs 
infused new life into dead Byzantine forms, carrying them through Italy, Spain and France to fecundate Christian thought under the name of the Romanesque. But the purest inspiration of Saracen art found its expression in Egypt and in Spain when the soul of Islam, satiated with strife, sought to transmute itself into beauty. Its earliest effort seems to have been made when the Tartar Ibn Touloum reigned on the banks of the Nile. His mosque is a ruin, but a colossal ruin, for he meant it to surpass in grandeur the great fane at Kairouan. It is said that his Michael Angelo was a Christian slave, but in any case the cloister, which still bears witness to Ibn Touloum's ambition, proves that the pointed arch was dedicated to the service of Allah some three centuries before it became identified with Gothic architecture. This mosque is more suggestive of a fortress than of a sanctuary. Even its minaret is a massive tower, for there was more iron than flexibility in the Moslem consciousness of the ninth century after Christ.

Few monarchs have exchanged a throne for such a grave as the tomb-mosque of Kait Bey on the outskirts of the city of Cairo. It belongs to the period when Saracen art was in its exquisite prime - the period of the Giralda at Sevilla-of the sumptuous temple at Cordova - of the inimitable Alhambra. Algeria possesses, in the mosque of 
Sidi-bou-Medine at Tlemcen, one example but little later than this epoch of Arab architecture whose idiosyncrasies are perfect harmony of proportion and mingled richness and restraint in ornament. That ornament was evolved in spite of the restriction imposed by the Islamic prohibition. In his anxiety to stamp out idolatry, Mohammed forbade the artist to introduce into his work any semblance of human or animal shapes, and in the monuments I have just described that injunction was rigidly adhered to. To the impetuous Arab soul this limitation must have been a burden, and in Asia, where anthropomorphic memories tainted the purity of the Theistic dogma, the letter, if not the spirit, of the command was frequently disregarded. The recent exhibition of Mohammedan art at Munich was particularly rich in specimens of Persian art, notably in carpets of the sixteenth and seventeenth centuries. By this time the severity of the geometric designs which distinguished the work of the fourteenth and fifteenth centuries had been exchanged for conventional reproductions of hunting scenes and flights of chimerical birds. Owing to the paucity of the Arabo-Spanish exhibits, it was not easy to compare the history of design as it progressed from mathematical regularity to the lax symmetry of Herat and Bokhara. In Persian art the influence of China is very evident, more especially in the 


\section{ARABS IN ART AND SCIENCE 9I}

miniature painting, an industry which flourished between the fourteenth and eighteenth centuries. And not only China, but also Mongolia and India contributed their national conceptions of colour and form to enrich an art which always manifested, with greater or lesser fervour, the tincture of Islamic thought.

The ceramic of Irak was resuscitated into new life in Spain. Recalling Etruscan and Byzantine models in the green and white of its early ware, it finally achieved the lustre of gold and rose praised by Edrissi in his description of Calat-Ayub. Bronze-work from Damascus, and crystal from Syria and Mesopotamia-very fully represented at Munich-demonstrated the variety in design and skill in execution which Moslem art attained in the East, and which was surpassed in Spain, where, according to Contrera's Étude descriptive, culture and magnificence graced a civilization which only Rome had equalled.

As a whole this exhibition brought together a cloud of witnesses which proclaimed, for those who had ears to hear, the debt that Europe owes to Islam. Not only can we trace in the treasures of Spain, of Venice and of Sicily, the direct influence of Moslem motives and ideas, but also in the designs which inspire the decorative art of Russia, Poland and Scandinavia. And I will say more. The revolt from an emasculated realism to the 
conventional reproduction of flower and geometric patterns, associated with the name of William Morris, is but an example in our own country of the return of the West to the East. The draperies he designed might have been woven at Samarcand. He was the pioneer of a veritable renascence which restored to a sane activity and loveliness the industrial art of Northern Europe. Thus that mighty spirit of Islam, derided by the ignorant, reputed dead by many of those who admire the monuments of its maturity, is even now extending its influence, through the plexus of Occidental sensibility, to revivify and restrain our conceptions of beauty and fitness.

But what evidence of this permeation exists in Algeria, where comparatively few traces remain of Islam's vigorous adolescence? It is to be found in the growing appreciation of the beautiful Arab villas which surround the town of Algiers, and of the invariable choice of that style, both for the houses frequently constructed by foreigners at Mustapha, and for the public buildings erected by the Government-General. It is also to be seen. in the care with which $\mathrm{M}$. Jonnart, ably seconded by the editor of the $A k h b a r$, protected the mosques against the attacks of ignorant iconoclasts from his own country. Is it not time, moreover, that Europe began to realize its obligations to Islam, and to repay some fraction of its debt by awakening 
the modern followers of the Prophet to a sense of their great past. For it must be confessed that the Arabs, like the Egyptians of to-day, have no more appreciation for the art of their ancestors than Italians have for the wonders of medieval Florence and Rome. In Algeria the few industries, sickly relics of bygone proficiency, are dying or dead. Only the intervention of the French administration can save those that are still susceptible of revival by coming to the assistance of the few surviving workmen, now old and discouraged, who are capable of handing on the secrets of their craft to their sons.

It cannot be said that the efforts hitherto made by the authorities towards the resuscitation of native industries have accomplished much. With the exception of the school of embroidery instituted by Madame Ben-Aben, who owns a superb collection of ancient Arab needlework, none of the establishments subventioned with the object of giving an impetus to the weaving of carpets and to embroidery on leather produce work that has the slightest artistic value. It is true that the vulgar and impermanent aniline dyes, recently used in the fabrication of Algerian carpets, have been forbidden in the Government schools. But the carpets they produce are, for want of good models, as crude in colour and design as those on sale in the Jewish shops of the Bab-Azoun. Why should not the 
schools have the benefit of the beautiful models that do exist in the country? Sketches from the antique carpets in the museum at Mustapha might surely be made for the pupils to copy, according to the suggestion of M. Stephane Gsell. "The Moghreb," he writes in his pamphlet on the subject, "forms, like Spain, a province of Moslem art, with its own local character, which ought to be maintained. But this country has also received at different periods a current of artistic influence which unites her with the Orient. All Moslem styles are but separate dialects of the same language."

M. Gsell is a strong advocate for establishing local industries in the towns and villages where they formerly flourished, instead of centralizing them in a School of Native Art, with which it was at one time proposed to endow Algiers. But if these efforts are to create anything beyond new berths for a crowd of French Inspectors, ignorant of, if not antagonistic to, all native art, it is essential that a permanent exhibition of the work done in the schools should be opened, preferably in a wing of the Mustapha Museum. Tourists who can discover nothing worth purchasing amongst the trash exposed for sale in the town of Algiers would welcome such an opportunity of acquiring genuine native productions. The fact that in Morocco carpets, pottery and embroidery, excellent both in 


\section{ARABS IN ART AND SCIENCE 95}

colour and pattern, are being produced without official encouragement, inclines one to fear that the contact of Occidental civilization has extinguished the originality and artistic sense of the Algerian Arab. If this is so the debt of France to Islam is even greater than ours. That it should have been left to Munich to assemble a collection such as the Occident had never before beheld shows that the two nations who count among their subjects the largest number of Moslems have let slip a priceless opportunity to remind Europe-and themselves-of that fact.

In their passage across the universe the Arab seized on the buds both of Greek science and of Indian philosophy, and brought them to flower in the warm shadow of Islam. The former gave them geometry, the latter algebra, and they soon left their teachers far behind. By the tenth century the Saracens had reached the limits of spherical trigonometry, besides solving quadratic and even cubic equations. In astronomy great strides were made during the reign of the Abbaside Caliph, El-Mamoun, the Augustus of his race. The obliquity of the ecliptic, the diameter of the earth, and even the precession of the equinoxes, were calculated with accuracy in the ninth century, and in the twelfth Geber constructed at Sevilla the first astronomical observatory the world had ever seen. Under the Caliphs schools of therapeutic science 
were established at Bagdad, Damascus and Cairo, where the works of the Greek Hippocrates and Galen formed the basis of instruction. Ultimately, however, these were superseded by the Materia Medica of Avicenna, whose treatise may be regarded as a prelude to that of Paracelsus.

Nor does this cover all the branches of scientific lore which the children of Islam explored and enriched. The gradual emancipation of Christendom from monastic superstition and ecclesiastical tyranny was largely due to the magnetic quality of Arab learning. Christian students thronged the Universities of Bagdad and Cordova. Gibbon is my authority for the assertion that the Ommeyades of Spain possessed a library of six hundred thousand volumes, and founded upwards of seventy public libraries in the province of Andalusia alone. In Bagdad eight hundred and sixty licensed physicians fought the ills its flesh was heir to, while in referring to Spain he writes, "The life of Catholic Princes was entrusted to the skill of the Saracens, and the school of Salermo, their legitimate offspring, revived in Italy and Europe the precepts of the healing art."

Modern discovery has, of course, far transcended their pathology, and of surgery their knowledge was little or none. But in the field of applied science Arab genius led the way to manufactures whose methods we have improved, but whose 



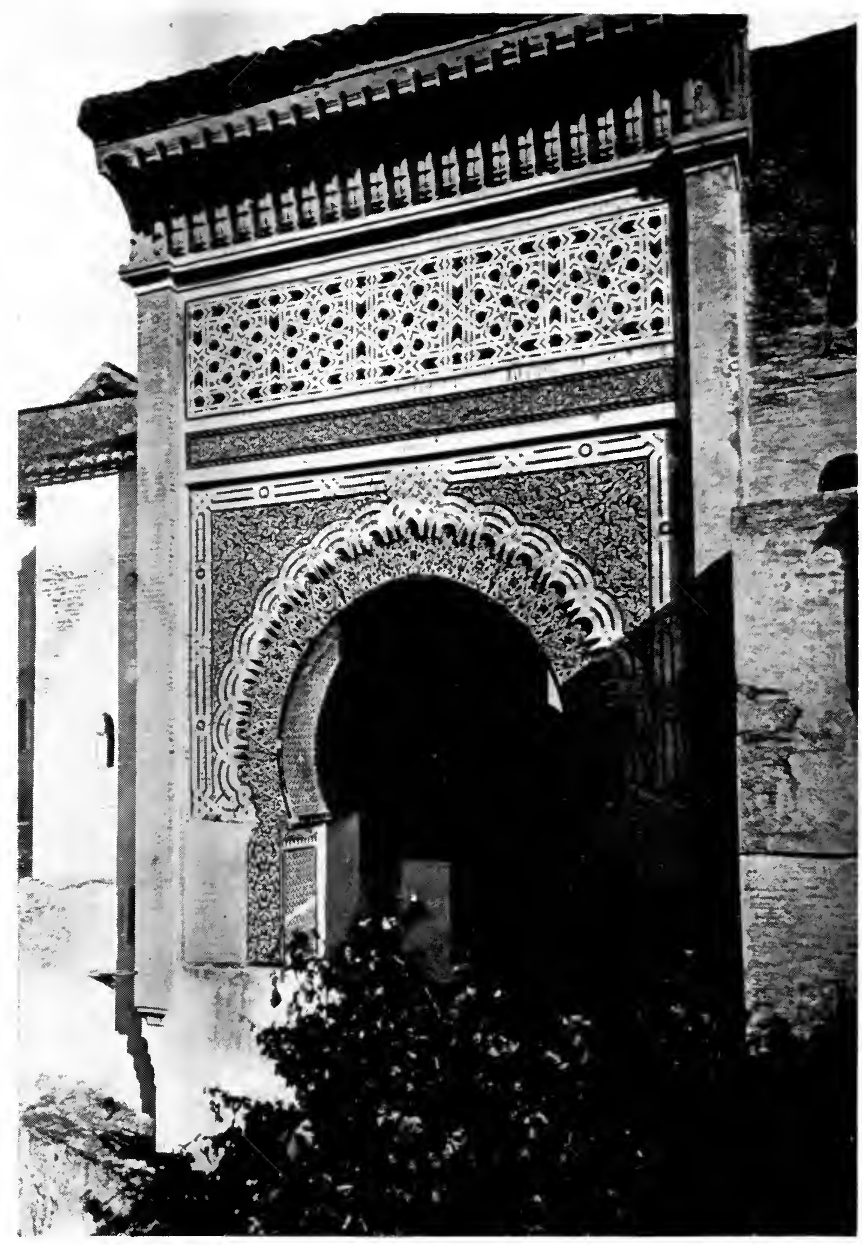

THE MOSQUE OF SIDI-BOU-MEDINE 


\section{ARABS IN ART AND SCIENCE 97}

products we have never excelled. Writing-paper was made in Mecca as early as A.D. 706, whence it was introduced to the Occident, and, some years later, the use and fabrication of silk and cotton stuffs. The sword-blades of Damascus have never been surpassed, except by those of Toledo, while the Crescent still crowned its heights. We owe, moreover, to Islam the invention of the mariner's compass; probably, also, that of the pendulum and the semaphoric telegraph. While Europe slept they trimmed the torch wrested from the expiring antique world. Its light, which they handed on, burns yet. Thus has the empire of the Arab mind outlived the sovereignty built up by its sword. 


\section{CHAPTER VI}

\section{THE TURK IN BARBARY}

ThERE are some places, as there are some people, whose very names seem charged with magnetism -names whose cadence weave a spell which subsequent sight and knowledge either fortifies or dissipates. Long before I heard of Sidi-BouMedine, who, seeing the glory of Tlemcen, died in order that he might rest therein for ever, I felt that for me the sonority of these twin syllables would triumph over any impediment of distance or discomfort. When, therefore, I discovered that Tlemcen contained one of the most beautiful mosques in Islam, when the story of Abd-el-Kaber added its glamour to that of the ancient capital of the Moghrebin Empire, my determination to see Tlemcen became imperative. A night's journey from Algiers across the plain of the Cheliff brought me within sight of its emerald hills intersected by countless cascades. Everywhere around Tlemcen you hear the gentle splash of water trickling through groves of fruit trees, everywhere you see gracious signs of Nature's fertility as she spreads her green mantle over ruins 98 
still significant in dilapidation. But Tlemcen's opulent spring-time is cold and rainy. One might be in Central Europe, and it was perhaps this climatic resemblance to Andalusia which induced the Almoravide conquerors to build, in the eleventh century, a city on the site of the Roman town of Agadir.

Thus Tlemcen arose amid her cascades, so often incarnadined as the Moorish Empire waxed and waned by the blood of the rival dynasties who fought to possess her. It was the great Yarmorasan of the Beni-Zeiyan who first made Tlemcen strong as well as fair by building a mechouar, or citadel, in the heart of her gardens. That fortress, which shelters a French garrison to-day, was, during the troublous years between 1837 and 1843, the stronghold of the Emir Abd-el-Kader, to whose domination Tlemcen was ceded by the ill-considered Treaty of Tafna. Suppressing the ugly modern streets, we can more or less realize what the Tlemcen of Abd-el-Kader's love was like. But the Tlemcen of the fourteenth century, a centre of learning in the civilized world and the capital of the Merinide kingdom, with its numerous mosques and universities, we can only see in dreams.

It was a Merinide King of Fez who, during the siege of Tlemcen, built a sister city without its gates. Of El-Mansourah nothing remains but a 
gigantic skeleton whose broken walls, red as the ferruginous earth from which they rise imperially, seem to merit their title of "The Victorious." An assassin's knife saved Tlemcen from the first besieger, Abou Yacoub Youssouf, but forty years later the last of the Beni-Zeiyan perished heroically while defending the Mechouar, and the Merinide reigned in his stead. No change of dynasty, however, threatened the spiritual supremacy of SidiBou-Medine, who had become patron saint of the city wherein he had chosen to expire. In 1339 a Merinide monarch, Abou Llassen, built in his honour the mosque which bears his name, and a few years later the Medersa, or University, still standing, though much restored, by its side on the shoulders of the hill of El-Eubbad.

To-day the latter part of the pilgrimage to his shrine has to be made on foot, for the road, as it approaches the village, degenerates into a stony track. It winds up the hill bordered by low, formless houses which look like caves hewn out of the rock, half concealed by a tangle of vines and fig trees. Above this labyrinth of stones and verdure towers the minaret of the Mosque, covered with faience whose green and gold glitters in the pallid sunlight. Opposite the great sculptured portal, inset 'with coloured marble, stands the cenotaph of Sidi-Bou-Medine. If he sleeps less well than he anticipated under his drapery of silken stuff, the 


\section{THE TURK IN BARBARY}

cause of his disquiet should not be far to seek. For is not this contrast between past beauty and present squalor symbolical of the destinies of Islam? Symbolical, too, of the faith of Islam, as it was in the era of their construction, are the rounded arches of the central court. Unlike the Gothic arches in the naves of our cathedrals, they do not aspire. They remind one, on the contrary, of that chapter in the Koran which begins, "This is a book in which there is no doubt." They are the expression of a faith resting on conviction rather than on hope-fiercely militant, but never fiercely ascetic-a faith as different in quality from Christian faith as the Oriental consciousness is from the neurasthenic soul of the West.

Unfortunately the sanctuary of Sidi-BouMedine is all that remains to us of the Moghrebin Empire. The Almohades wrested the sceptre from the Almoravides, and the second, or Hilalian, invasion once more set Arab and Berber at each others' throats. It was about this period that the division of Northern Africa took place into three provinces which more or less correspond with those territories known to-day as Morocco, Algeria and Tunisia. At that time each province was ruled by descendants of the competing dynasties. They carried on their bloody dissensions until the royal tribes had sunk one after another into the grave of impotence and ruin. Once again North- 
ern Africa was reduced to a state almost indistinguishable from its prehistoric barbarism. The incoherence of its government was Catholic Spain's opportunity. As I have described in Chapter II, Pedro da Navarro eagerly undertook the execution of Ferdinand's design to expel the Moor from the Moghreb as he had been expelled from Andalusia. Pedro was rather more successful in El-Djezair, as the presence of the Peñon still attests, than he was at Bougie, but to the Moors any domination was better than the heel of the detested Spaniard. If doomed to some sort of dependence, they preferred the tyranny of Islam to that of an alien faith.

At this critical moment the Turks, having extended their conquests into Europe by the taking of Constantinople in I453, were in the act of constructing a navy for the devastation of Christendom. Their ships, only inferior in number to the fleets of Venice and Genoa, owed their strength and swiftness to the genius of a Greco-Turkish adventurer called Kheir-ed-Din. His brother Baba-Roudj, or Barbarossa, as he is more commonly named, had lost his life in aiding the Sheikh Salim to oust the Spaniard from El-Djezair. This object accomplished, Kheir-ed-Din took possession of the port, which he proceeded to fortify, and at the same time to build a harbour for his fleet. Realizing that he would have to defend his new possessions against the allied forces of Catholic Europe, 
he placed himself under the protection of Suleyman the Magnificent, then securely established upon the throne of Constantinople. The "Grand Signor" had the wisdom to perceive the services which this sea-wolf could render to the Ottoman Empire. So he lost no time in responding to Kheir-ed-Din's appeal by creating him Dey of El-Djezair, and by supplying him with money and ships built and manned under his own direction.

Meanwhile, following in the steps of St. Louis, who had expired in a fruitless attempt to convert the infidel ruler of Tunis, Charles $\mathrm{V}$ set sail to reclaim that country which had also been forcibly added by the ubiquitous Corsair to the Turkish dominions. While he was engaged in this crusade, Kheir-ed-Din slipped across the Mediterranean, sacked the town of Port Mahon, and returned to El-Djezair with a rich Portuguese galleon, six thousand captives and other booty. These evil tidings reached Charles $\mathrm{V}$ at the very moment when he was celebrating the success of his enterprise. In the light of Kheir-ed-Din's exploit, the new Order of Chivalry just founded to commemorate the annihilation of the pirates looked a trifle premature. Exasperated by these continued depredations, the Emperor determined to attack his enemies in their lair, and the next few years were spent in the construction of a flotilla destined to 


\section{IO4 ASPECTS OF ALGERIA}

crush once and for all the power of the Moslem bandits. The famous Admiral Doria, who had learnt from bitter experience the strength and resources of the foe, did his best to persuade Charles $\mathrm{V}$ to abandon, or at least postpone, the expedition. But to these counsels of prudence the Emperor turned a deaf ear.

While these preparations were afoot, Kheir-edDin had returned to Constantinople, where he had been appointed High Admiral of the Turkish navy, leaving one of his most redoubtable captains, Hassan the Eunuch by name, in command at El-Djezair.

Landing almost unopposed, Charles saw victory already in his grasp. But he counted without the fcrces of Nature, on this occasion, as on many others, in league with the rebels. One of those storms which convulse the elements perhaps twice in a century burst that day upon the hosts of Christendom. Surrounded by his Knights of Malta-Corsairs as unscrupulous as any in Barbary-Charles watched the fury of the waves working their will upon his fleet. In six hours one hundred and fifty of his vessels were engulfed, and all his stores and powder saturated by the diluvian rain, which converted his camp upon the hill behind the town into a quagmire. Retreat - a shameful retreat-became imperative, and the demoralized troops rushed in disorder down to 
the shore, pursued not only by the hurricane, but by a raking fire from Hassan-Agha's men.

Nor was it possible to accommodate all that remained of the Christian forces upon those ships which had survived the storm. Stores and ammunition were cast into the sea, and with them the finest horses of the famous Spanish breed. On this disastrous errand perished not only the flower of Spanish chivalry, but many knights, French, Italian and even English, who had been induced to join in the sacred mission. The gall of this defeat, so unexpected and ignominious, ate like a canker into the Emperor's proud spirit. On the other hand, the whole coast of Barbary rejoiced in the triumph of piracy. Christian slaves became a drug in the market at El-Djezair, and Admiral Jurien de la Gravière, seeking to minimize the catastrophe in his chronicle, threw the entire blame upon the climate of Africa, "which was evidently," so he wrote, "incompatible with deeds of chivalry."

If ever a gale blows round Algiers it is still on the slopes leading up to Fort l'Empereur that you feel it most. On the day when I climbed the hill to look at the colossal battlement which Hassan built on the site of the Spanish camp, the wind nearly took me off my feet. Nothing interrupts its course from the Atlantic save a native village hedged by cactus-thorns, and a few dejected 
stumps of olives, the ghosts, one might say, of Charles's soldiery.

Though Kheir-ed-Din was destined to die in his bed in Constantinople, the fame of the Corsairs did not die with him. His heirs on the Barbary coast-Dragut Reis, Sinan Pasha, Salah, among others-continued to pursue the remunerative career of piracy, though not quite in the grand manner of their illustrious predecessor. Sometimes Gianettino Doria, kinsman and follower of the great Admiral, would capture a few galleys, once even Dragut himself, but none of the expeditions sent against them by the outraged Christian powers succeeded in securing the safe navigation of the Mediterranean Sea.

In 16 I 7 a French fleet of fifty vessels under Beaulieu seized a brace of their craft, which was more than Sir Robert Mansel's squadron achieved. Some years later the Venetian admiral, Capello, did inflict severe punishment on the marauders, and in I682 Louis XIV, enraged at the frequency of piratical incursions on the coast of Provence, despatched a large fleet to bombard El-Djezair. On that occasion Admiral Duquesne destroyed the town, though the Corsairs promptly avenged this humiliation. But when Duquesne reappeared during the following spring the frightened Dey began to sue for a truce. His pusillanimity, however, cost him his life, for Mezomorto, the pirate 
commander, caused him to be put to death; and then, to show the French how little he was disposed for peace, he shot their Consul from the mouth of a cannon. In reply to this defiance, Duquesne razed El-Djezair to the ground and burnt every ship in its harbour. But when Mezomorto eventually made overtures for the cessation of hostilities, his request was granted almost without conditions. Thereafter most of the European powers found it cheaper to buy the neutrality of the Corsairs than to make war upon them.

It was not, however, until England took Gibraltar and Port Mahon that they made any pretence of observing the terms of their treaties. In 18 I 5 Lord Exmouth commanded an expedition sent to El-Djezair to demand not only tranquillity in exchange for an annual tribute, but the liberation of all Christian slaves.

The number and condition of these has been grossly exaggerated, but there is little doubt that prisoners taken in the battles of those days were everywhere treated with great inhumanity. "The terrible grave of a galley, let us remember," writes Mr. Stanley Lane-Poole in his interesting work on The Barbary Corsairs, "is depicted from Christian models. A hundred and fifty years ago such scenes might be witnessed on many a European vessel. The Corsairs of Algiers only served their enemies as they served them; their 
galley-slaves were no worse treated, to say the least, than were Doria's or the King of France's own. Rank and delicate nurture were respected on neither side."

The Algerine fleet never seems to have attained, either in numbers or size, anything like the proportions of the European navies. Built for speed, the plundering galleys were infinitely smaller and swifter than the great ships they ravaged. Haedo, who wrote about the middle of the sixteenth cen-tury, gives some curious details concerning the pirate squadron. From him we learn that their vessels were entirely built, and, as far as possible, manned by Christians. The builders received a monthly wage of six to ten quarter-dollars, and a daily allowance of three loaves of bread. It was the same in quality as the bread supplied to the T'urkish troops, only each soldier received four loaves a day instead of three. "God send you a prize!" shouted the crowd who watched the launching of a galley from the port of Algiers, its prow red with the blood of a slaughtered lamb. And God-or the devil-usually did.

It was not every day, however, that the prize included a captive whose name all Europe has delighted to honour. But the Captain of Corsairs who took Cervantes, on a ship homeward bound to Spain from Naples, did not realize the importance of his capture. Unfortunately perhaps for 
Cervantes he was the bearer of letters of introduction to Don John of Austria; and so the pirates took him for a rich noble or merchant capable of paying a heavy ransom for his liberty. In spite of many daring attempts, Cervantes never succeeded in escaping, and at the end of five weary years he was liberated by English gold in 1580 , through the medium of one Father Juan Gil. His nobility of character must have impressed even his tyrants, for he appears to have been treated with courtesy and consideration. On this point it is difficult to determine how far the cruelties recounted by Father Dan are in accordance with fact. His accusations against the Dey and his subjects are not confirmed by other chroniclers of the time. Many Christian prisoners were doubtless chained to degrading work and barbarously ill-used, but the self-interest of their taskmasters must, in most instances have led them to control their ferocity.

After the destruction of the port by English guns, the Dey consented to liberate twelve hundred and eleven captives, the majority of whom were Italians, besides promising to respect his covenant for the future. It did not take long, however, to restore the fortifications of Algiers to their former strength, and from time to time British and other merchantmen were still attacked and despoiled by galleys flying the Turkish flag.

Two centuries had elapsed since Kheir-ed-Din 


\section{10 ASPECTS OF ALGERIA}

persuaded Suleyman to accept the allegiance of Algeria. That country had remained under Turkish domination till I7IO, when the Janissaries threw off the yoke and expelled the Governor appointed by the suzerain power. These mercenaries, recruited chiefly in Asia Minor, always chose their officers from their own rank, and resented any attempt on the part of the Sultan's representative to extend his authority over them. After the expulsion of the Governor, the Janissaries elected the Dey themselves, but his reign was frequently short and his end a violent one.

No attempt was ever made by the Turks to colonize Algeria. They contented themselves with governing it from the capital, with the aid of a military corps, called the Maghzen, composed almost exclusively of Kouloughlis, or the offspring of Turks married to Arab women. These halfbreeds were debarred from many of the privileges enjoyed by pure-blooded Turks; but they formed a capable militia, somewhat analogous in character to our Irish Constabulary. Besides the Maghzen, who kept order and collected taxes, the Turks profited by the jealousies that have always disintegrated Arab society, to play one tribe off against another. In exchange for tribute and other services, the government of the Dey extended its protection to those sections of the nomad population who gave tangible proofs of their loyalty. 
The Berbers of the mountains remained, however, outside these combinations. They resisted any attempt on the part of the Maghzen to collect taxes; and the Odjac, or central Government, recognizing the impossibility of subduing then: by force of arms, ended by letting them alone.

That part of Algeria occupied by the Turks was, in fact, restricted to the province of Constantine and the neighbourhood of the port of Algiers, besides a few fortified towns in the interior, of which Biskra was the most important. In the sixteenth century Constantine became the capital of a separate province with a Dey of its own. Its history, like that of Algiers, consists of a long series of assassinations, the cause, or effect, of sanguinary struggles. At the time of the French conquest the Turkish population of Algeria did not surpass fifteen thousand; while the Kouloughlis numbered some five or six thousand more. Those Arab tribes not especially attached to the Odjac were oppressed by grievous taxation. But the chief revenue of the Dey's government came from the practice of piracy, and from the annual subventions paid by the powers of Europe in the vain hope of securing free passage for their vessels through the Mediterranean Sea.

As Mr. Lane-Poole points out in his work before referred to, the negotiations carried on between the different nations and the Dey were, 
for at least two centuries, distinguished by incredible pretensions on the part of the latter, and equally incredible forbearance on the part of the former. This attitude was naturally the result of political considerations. To quote his exact words : "Policy led the Dutch to ally themselves with the Algerines early in the seventeenth century, because it suited them to see the lesser trading States preyed upon. Policy sometimes betrayed England into suffering the indignities of subsidizing a nest of thieves so that the thieving might be directed against her enemies. Preoccupation in other struggles - our own Civil War, the Dutch War, the great Napoleonic War-may explain the indifference to insult or patience under affront which had to be displayed during certain periods. But there were long successions of years when no such apology can be offered, when no cause whatever can be assigned for the pusillanimity of the governments of Europe but sheer cowardice, the definite terror of a barbarous power which was still believed to possess all the boundless resources and all the unquenchable courage which had marked its early days."

So for centuries Europe paid tribute to a band of ignorant and demoralized freebooters for the purpose of exempting its ships from molestation. Nor did we disdain to enter into diplomatic relations with them. Consular agents were accredited 


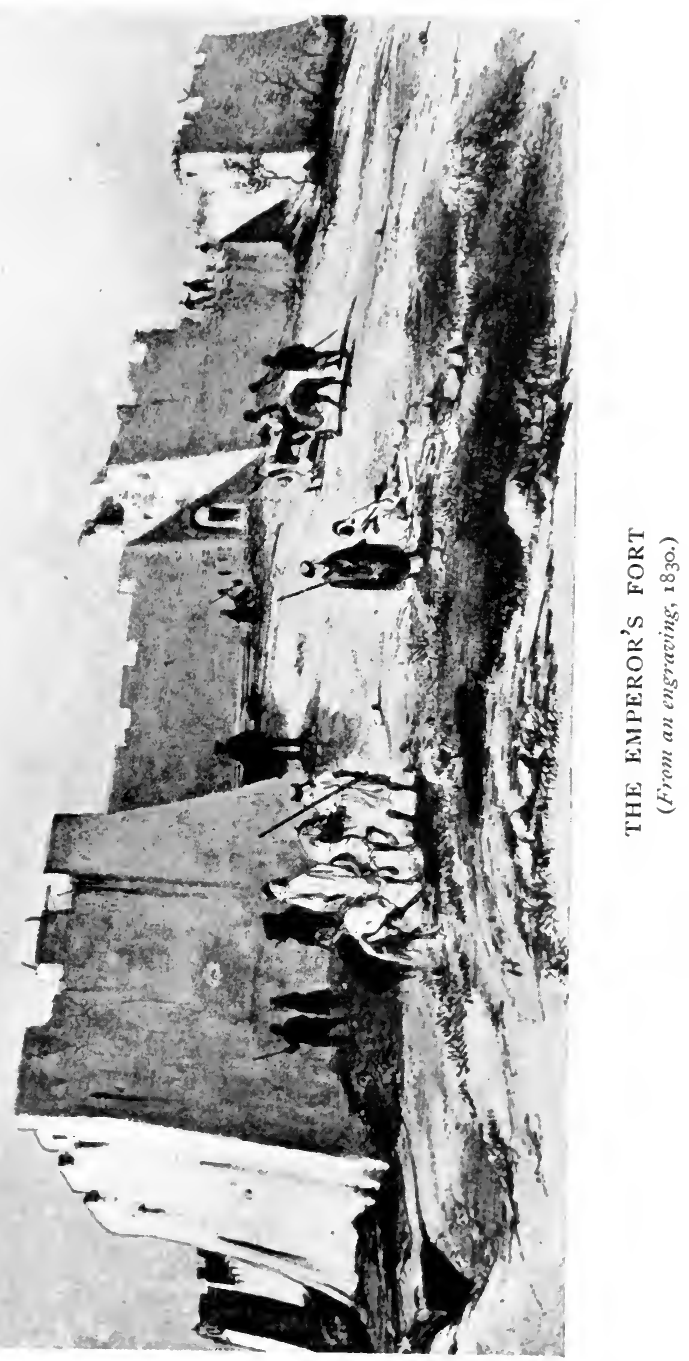



to Algiers, and in their endeavour to protect the lives and property of their compatriots they suffered humiliations which their governments were slow to resent. It was America who first set the example of refusing the insolent demands of the Dey for an increased subvention. Anxious to prove the quality of her young timbers, she sent a squadron across the Atlantic, and so made the first serious effort to suppress robbery on the high seas. Her spirited action stimulated Europe to a sense of its responsibility, and the despatch of Lord Exmouth demonstrated England's sympathy with the American point of view.

To the modern world, built up on the respect for property and the liberty of the individual, piracy was an outrage, the more odious because incomprehensible. Born in the age of chivalry, it was then a natural, if extreme, expression of personal valour following the line of least resistance. When all men bore arms and were imbued with the passion for adventure, the bravest became Corsairs whether they believed in Christ or in Mohammed. In the former case their exploits were called Crusades, and the name constituted the only difference between them.

But as the spirit of romance died out of the human heart, and the desire of gain took its place, the Corsair degenerated into a pestilent robber who followed his nefarious trade for what he could get 


\section{4 ASPECTS OF ALGERIA}

out of it. His courage, that had once inspired great deeds and the song of Troubadours, decayed into mere swagger; and so piracy, losing its only justification, became, in the practice of the later days, nothing more than blackmail. When one of them naïvely remarked to Consul Cole, "The Algerines are a company of rogues, and I am their Captain," he expressed no more than the unromantic truth.

So the rogues had to go as they richly deserved, but it was not the English who finally exterminated them. Lord Exmouth departed as he came, believing quite erroneously, like Charles $\mathrm{V}$, that he had abolished piracy, and thus ended the only scrious attempt ever made by this country to shape the destinies of Algeria. 


\section{CHAPTER VII}

THE FRENCH CONQUEST OF ALGERIA

IT is rarely possible to justify, from a purely ethical point of view, the incursion of a civilized nation upon territory that does not belong to it; even if the actual possessors have endangered the peace of adjacent countries. This extenuating circumstance certainly existed in the case of Algeria, as I have explained in the preceding chapter. America had at length shamed the powers of Europe into adopting a more energetic attitude towards the marauders, who persisted in converting the Mediterranean Sea into a place of terror. But Lord Exmouth had merely succeeded in scotching the piratical snake, and we have only ourselves to blame if France decided to finish the work we abandoned before completion. Other reasons less disinterested contributed to the decision of Napoleon's Government to send a punitive expedition into Algeria.

The consular service of the European powers was at that epoch very inferior to what it is to-day. The position of a diplomatic agent on the Barbary ccast was not in any sense an enviable one, nor 


\section{ASPECTS OF ALGERIA}

would it have been endurable to men of spirit and character. Sir Lambert Playfair deplores, in his history of that period, the discreditable dealings of some of our Consuls in Algiers, and the representatives of other nations were no better than our own. In 1830 the interests of French subjects in the capital of the Dey were in the hands of an ex-dragoman of Pera, named Deval, who, in addition to his official duties, was engaged in commercial transactions of a nefarious kind. In this traffic he was associated with a couple of Jews, ostensibly dealers in corn, called Bacri and Busnach, who had supplied the French government with large consignments of wheat at exorbitant rates. With the object of obtaining some reduction in the price, the Treasury of the Directoire withheld payment of Bacri's account. He pleaded this delay in excuse for his refusal to discharge his debt to the Dey, his creditor on this occasion as well as his master. But when Bacri had received, through the intervention of Talleyrand, a large portion of his account, and still showed no inclination to settle, the Dey sent for Deval and complained of his partner's conduct. A lively altercation ensued which terminated by the Dey's throwing his fan, or possibly his fly-whisk, at the French Consul's head in reply to an insulting speech.

Although this gesture was no more violent than the ex-dragoman deserved, Deval persuaded his 


\section{THE CONQUEST OF ALGERIA I I 7}

government that the Dey had insulted France in the person of its representative. Anterior to this incident, Charles $\mathrm{X}$ and his ministers had discussed the feasibility of confiding the suppression of the Algerine pirates to that hardened old warrior Mehemet Ali. On the principle of setting a corsair to catch a corsair he was admirably suited to the task. He had even expressed his willingness to undertake it for a consideration of ten million francs in cash, provided four men-of-war were placed at his disposal, equipped by French seamen, and other necessary means of transport.

But for Jewish intrigues and their mouthpiece Deval it is more than probable that the Egyptian Khedive would have been hired to carry out an enterprise for which no one in France had the slightest inclination. Such a solution would not, however, have suited Jacob Bacri, whose letters from Paris, addressed to his brother, throw rather a lurid light upon the story. This impression is confirmed by Galibert, an historian of the period, who had access to official documents which have since disappeared. But though the prospect of securing the services of Mehemet Ali was abandoned, some years elapsed before France decided to stamp out piracy with her own arms. On the I $3^{\text {th }}$ of June, I830, however, a considerable French force landed at Sidi Ferruch, and a fortnight later Admiral Duperré lay with a large fleet 
outside Algiers. The bombardment only lasted twenty-four hours, and its success was a foregone conclusion. The surrender of the Dey terminated the Turkish domination and, at the same time, the reign of the Corsairs in Africa.

On land the French troops encountered little or no resistance, for the Kabyles, who had descended from their mountain at the approach of the invading force, detested the Turks, and were glad to be delivered from their rule. They were easily persuaded to retire after the skirmish at Staoueli, believing that the French would follow their example as soon as their mission was accomplished. This belief, founded on the formal declaration of the French Government was shared by the whole of Europe, nor is there any reason to doubt the sincerity of these assurances at the time they were given. Beyond the too evident existence of the pirates, France was entirely ignorant of the country that lay behind the fortifications of Algiers, and this ignorance was responsible for the fatal policy adopted by the General de Bourmont towards the Turkish administrators. Instead of utilizing them and the Maghzen, the sole representatives of law and order in the country, to negotiate with the Arab population, the French committed the initial error of expelling them both. The offers of service made by the Beys of Titeri and Oran were rejected with scorn. This ill-judged action imposed upon 
the invaders the unforeseen necessity of subduing not only those Arab tribes who had retained their. independence, but also those who had allied themselves with the Turks.

For this task, which circumstances forced upon the reluctant French Government, no more disastrous choice could have been made than that of De Bourmont's successor, the General Clauzel. His folly in applying for assistance to the Dey of Tunis was only equalled by his brutality towards the Arabs. If in those early days conciliatory measures had been adopted the tribes would probably have consented to establish the same sort of relations with the French as they had previously had with the Turks. But the needless severity of General Clauzel's methods, which were imitated by his immediate successors, destroyed all possibility of a peaceful settlement. The lamentable failure of these commanders induced the metropolitan government to despatch, in 1834, a Royal Commission to Algeria. As a result of its recommendation, General Voirol was sent out with instructions to use every effort to conciliate the natives. But Voirol came too late. The natives were by that time irrevocably alienated, and the action of the first Governor of Algiers, General Drouet d'Erlon, was calculated rather to intensify than to diminish their distrust. The moment was favourable for the appearance of a leader who should rally to his 
banner all the disunited elements of the Arab race; and forthwith the leader came. This remarkable man, who retarded the French conquest of Algeria for fifteen years, was the son of a Maraboutic family which traced its descent from the Hachems of Medina. His father, Sidi Mahdi-ed-Din, had formerly acquired considerable influence over the Arabs of Oran, who, weary of the oppressive rule of the Turkish Bey, had prayed him to undertake the armed defence of their interests. Judging himself too old for war, he persuaded the tribes to accept the leadership of his son, and thus Abd-elKader was proclaimed Sultan of Oran in 1832 at the age of twenty-four.

His authority was at once disputed by the Bey Mustapha ben Ismail, from whose service Abd-elKader had failed to detach the Maghzen, with the result that he was defeated in his first encounter with the Turks, and owed his escape to the fleetness of his horse. It is possible that his influence over his compatriots would not have survived this initial rebuff had it not been for the unexpected help tendered to the youthful Sultan by General Desmichels. In the light of subsequent events the French General's policy seems as incredible as that adopted by his predecessors. One may suppose that he intended to use Abd-el-Kader to disembarrass the country of the remnant of Turkish administration. Be that as it may, General Desmichels 
THE CONQUEST OF ALGERIA I 2 I

evidently hoped to convert Abd-el-Kader into an instrument of peace, so he installed him as Governor of the Province of Oran with the title of Emir, besides supplying him with arms and ammunition. Thus sustained, he continued the combat against his old enemy Mustapha ben Ismail, who had retired to Tlemcen, still occupied by a Turkish garrison.

The news of this pact was received with indignation in France. But the supersession of Desmichels by Clauzel merely gave the latter another opportunity for displaying his crude tactics, which were as ineffectual as before. He was speedily succeeded by a man of far superior calibre. General Bugeaud's instructions were, however, to make peace at any price, and thus his generosity to the Emir surpassed even that of Desmichels. By a treaty signed at Tafna in 1837 the ancient Beylik of Titeri and a portion of the department of Alger was ceded to Abd-el-Kader, as well as the province of Oran which he had previously governed. In return for these concessions the Emir acknowledged the suzerainty of France, and undertook to pay a yearly tribute in kind for the sustenance of the French troops.

Unfortunately for the peace of Algeria, the ambiguous phraseology of this treaty led to misunderstanding, and eventually to another outbreak of hostilities. But during the years that elapsed 
between its acceptance and the reappearance of General Bugeaud at the head of a hundred thousand men, Abd-el-Kader had greatly consolidated his position. After reducing the South, he had armed and organized a considerable force and had, moreover, established garrisons at Ain-Mahdi, Boghar and Taza. Bugeaud found the Emir entrenched at Tagdempt, which he had rebuilt and fortified, and to avoid unnecessary bloodshed envoys were despatched with the object of obtaining certain modifications in the Treaty of Tafna. But believing, rightly or wrongly, that the French had broken faith with him, Abd-el-Kader would yield nothing. As Bugeaud advanced he was joined by those fractions of the Arab population which the Emir had not succeeded in subduing. Fortune favoured his arms, and with their assistance he occupied Mascara, Mostaganem and Tebessa, thereby securing the allegiance of the tribes inhabiting the plain of the Cheliff and the Mitidja.

Abd-el-Kader was, however, confirmed in his resistance by promises of support from the Emperor of Morocco, to whom he had sent an ambassador with presents. But on hearing through the Kabyles that the Commandant Vallée and the Duc d'Orleans were marching on Algiers he decided to abandon Tagdempt for Tlemcen. After this retreat the Emir was not destined to retain long any fortified position, and thenceforward began a 


\section{THE CONQUEST OF ALGERIA I 23}

guerrilla warfare which lasted till I 844, when the capture of the Smalah at Taguin dealt a fatal blow to his power and prestige. The Smalah was composed of four concentric rings of tents, and was a veritable nomad town accommodating nearly twenty thousand persons, but its extent and the number of its inhabitants rendered it almost as immovable as a walled city. The picture painted by Horace Vernet to commemorate this victory hangs in the great gallery at Versailles, and gives some idea of the aspect of the Smalah. Its loss alienated many of the tribes who had hitherto believed in the eventual triumph of the Khalifafor the Emperor of Morocco had conferred this honour upon him-over the infidel invaders of their land.

It was not until his final defeat at the battle of Isly by General Bugeaud's troops in 1847 that the Emperor of Morocco withdrew support from his ally. Even then, had Abd-el-Kader been prepared to abandon the load of women, followers and baggage which impeded his movements, he could still have defied the French for a considerable space of time. It may be that he realized the hopelessness of struggling against the unlimited resources of a European power. On the advice of several of his Aghas the Emir took the course of writing a despatch to General Lamoriciere in which he offered to surrender on condition of being per- 
mitted to embark with his family either for Alexandria or for St. Jean d'Acre. The General sent his sword and seal in token of acceptance, but Abd-el-Kader insisted on having these stipulations confirmed in writing, and this confirmation was ratified by the Duc d'Aumale, who arrived simultaneously at the French camp. The Duc further pledged his word that the boat upon which the Emir departed should proceed directly for Alexandria after touching at Toulon. But no sooner had it weighed anchor in the French port than Abd-el-Kader was arrested and thrown into prison.

This scandalous repudiation of a compact with an heroic enemy is the most discreditable incident in the story of the conquest of Algeria. The noble character of the Emir aroused, however, the sympathies of the French people, many of whom saw a national dishonour in the broken faith of France, and during an interpellation which took place in the Chamber of Deputies a year later, General Lamoriciere acknowledged the immense saving of blood and treasure which the surrender of Abd-elKader had effected. But it was not until he had languished for five years in captivity that the exEmir was released by Louis Napoleon and conveyed to Damascus, where he died in 1883 . His oath, voluntarily given, never to intrigue against France, was scrupulously kept. During the massacre of 1860 he rendered signal service to his 


\section{THE CONQUEST OF ALGERIA 125}

former antagonists by protecting the lives and properties of Christians.

The admiration which this extraordinary man aroused in all Europeans who came in contact with him is the best proof of his genius. In the Private and Political History of Abd-el-Kader the Commandant Lacroix compares his marvellous capacity for organization to that of Napoleon. Between battles he immediately set to work building towns, striking coins and constructing munitions of war with the aid of foreign prisoners. His administration of the provinces he conquered revealed a matured design to build up once more the Moghrebin Empire. "Had circumstances placed him at the head of a civilized people with a disciplined army," writes Commandant Lacroix, "Abd-el-Kader might have become a second Bonaparte, whom he also resembled in his frugality, self-control, family affection and undaunted will power and courage."

His military tactics also drew enthusiastic comments from the Duke of Wellington. But these tactics were limited by the difficulties of training and organizing Arab troops, who resented all discipline and remained as they had ever been, brilliant in attack and weak in defence. When the numerical superiority of Bugeaud's forces compelled the Emir to adopt a defensive attitude the discouraged tribesmen began to desert his flag. 


\section{I26 ASPECTS OF ALGERIA}

They lacked just those qualities of tenacity and endurance which the situation demanded, and in this deficiency lay the chief reason for his failure. "He possessed, nevertheless, the genius," writes another of his admirers, the General Daumas, "to graft a military organization upon the most ardent passions that can inspire human conduct - the passions of patriotism and religious faith."

It is to General Daumas that we owe a translation in French of two poems in which Abd-elKader expresses his love of the land for which he fought so valiantly. The first describes his joy at the acknowledgment of his right to reign over the province of Oran. To his Oriental irnagination, Tlemcen was as a woman-won, the jewel of his kingdom wrested from all rivals. Something of the charm of his apostrophe is retained in the translation, which is short enough to permit of my citing it in extenso--

“Quand j’apparus, Tlemcen me présenta

Pour les baiser, ses mains douces et blanches,

Mon bras vainqueur, au dessus de ses hanches, Lui fit ceinture, et l'amour me tenta!

J'ôtais le voile d sa noble figure,

Et j'aperçus de ses dents le creneau

Qu'avait formé la grêle la plus pure ;

Sa bouche était de Salomon l'anneau.

Les grains éclos sur la fleur de sa peau

Faisaient duvet à ma main qui s'y joue!

Que d'ennemis sont morts de sa fierté !

Qued'amoureux, jaloux de sa beauté 


\section{THE CONQUEST OF ALGERIA}

Voulaient ravir ou de ruse ou de force

Ses frais jardins, voluptueuse amorce!

Mais son regard trempé dans le dédain

Les a tués, sous son rempart hautain :

Les cils baissés à moi seul, souriante

Elle me donna le baiser de l'amante!"

In the second poem that other side of the Arab nature sings the praises of the desert which is the Arab's true home. In the Éloge à la Sahara Abd-el-Kader celebrates the life of the tent, vaunting the superiority of "ce souffle embaumé qui double la vie" over the cramped existence of cities. Nor were his literary labours confined to poetry. In the seclusion of the Château d'Amboise he sought to relieve the burden of captivity by the study of philosophy. His book, Rappel à l'intelligent, avis à l'indifférent, enshrines the thoughts upon human destiny which those weary hours inspired. In this singular work the Arab warrior reasons like Kant and Cicero, and, reproaching the French for their growing irreligion, asserts the alliance between faith and reason in terms that remind one of St. Paul. The second part of the book, presented to the Sociéte Asiatique on the occasion of his election to its membership in $185^{2}$, deals with the evolution of the Oriental races and their written characters. Although his views on the subject might be contested by modern Orientalists, the depth and extent of his studies is amazing. 
In this phenomenal personality one seems to see a reincarnation of the early Caliphs, tempered by a knowledge of the modern world, with its mixture of practical energy and transcendental philosophy. The contemplative Oriental was modified in Abdel-Kader by the man of action-the activity of the soldier fighting a desperate fight against overwhelming odds. And he lost the great game because his people were unfit for the independence he strove to win for them. Once again the inability to cohere, to sink their private feuds for their common weal, delivered the Arab people into the hands of their enemies. Had they united to follow the Emir, had they allowed him to realize but for a moment his dream of empire, the French would never have succeeded in dominating the Hinterland of Algeria. But they exhibited on this occasion, as centuries before in Spain, the same incapacity to sacrifice tribal for national sentiment. In a house so divided against itself even the genius of Abd-el-Kader was powerless. To the end they doubted both his wisdom and his sincerity, and forsook him when loyalty might have turned defeat into victory.

In one respect at least he shared the traditional fate of heroes. Misunderstood by his own people, he was cordially and even extravagantly appreciated by his enemies. The description of his person by the Academician, Paul de Saint 



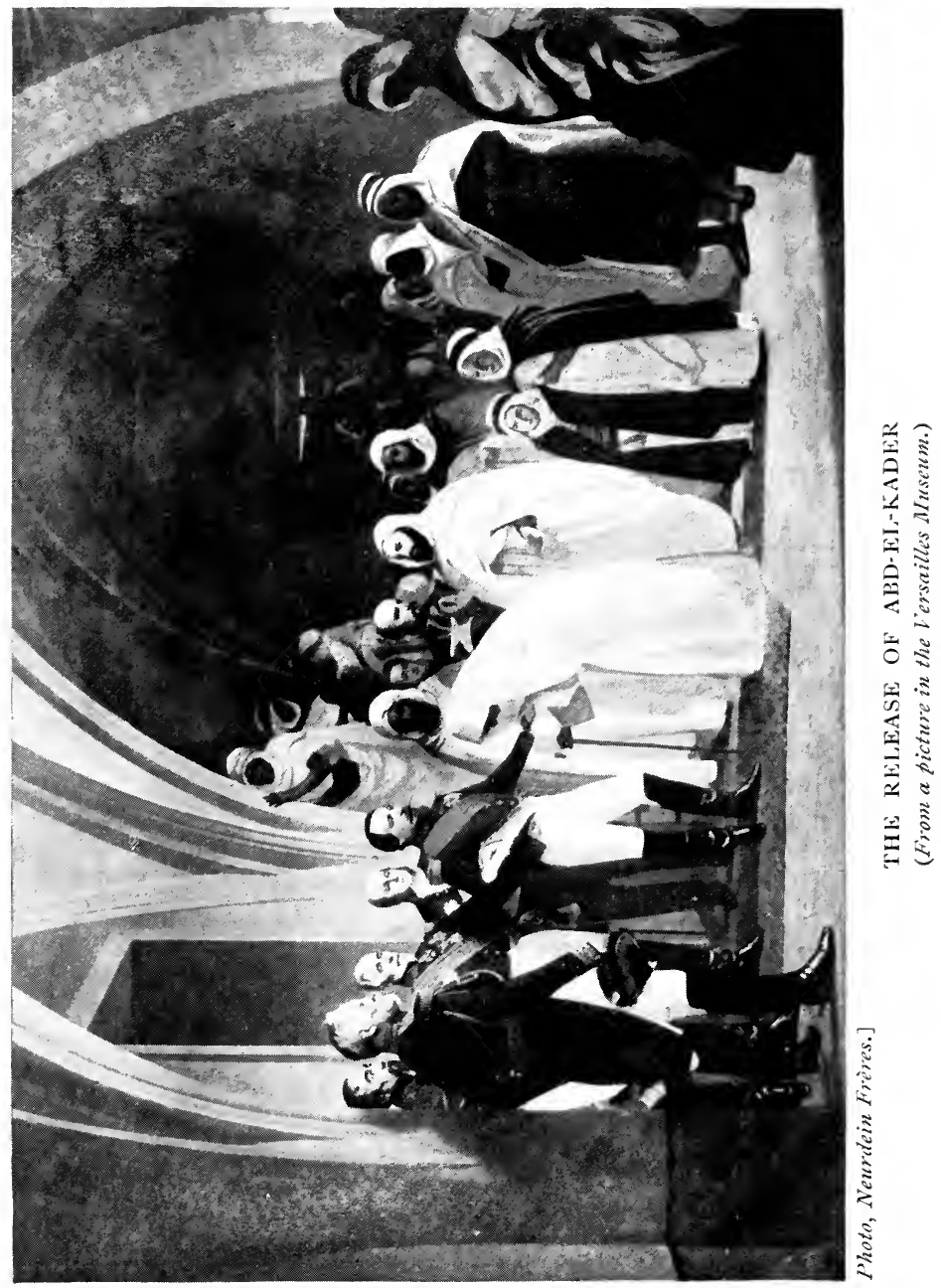




\section{THE CONQUEST OF ALGERIA I29}

Victor, who met the Emir on the occasion of his visit to Paris, illustrates the impression he created on a superficial though interested observer.

"All that still lived in a countenance already marked by a devastating asceticism is concentrated in the eyes-eyes whose depth and brilliancy is infinite and illumined by the light of prayer and ecstasy. No words can express the ardent mobility of their glance, at once rapid and soft, despotic and tender-a glance which reveals a slumbering fanaticism veiled by serene eyelids that seem to cover an abyss of luminous shadow. One feels that this man is possessed by illusions that fascinate and by an energy that exhausts both himself and itself. One feels his soul burning with the fire that can kindle war and inflame a whole nation. Such eyes should evidently be numbered among those earthly stars which God sets at rare intervals in the frame of the human face. They are stars drawing into their orbit whole series of events and the destinies of multitudes."

It would be difficult to equal, impossible to surpass, the generosity of such an eulogy. These quotations, which are a mere fraction of all that was written concerning the Emir Abd-el-Kader, suffice to show how he struck his contemporaries. Time seems to have already cooled that fervour, for a recent proposal to erect his statue in some 
square of the city which he loved has not met with the response it deserves.

After the psychological moment which might have robbed the French conquest of its sanguinary character had been missed, it was inevitable that the policy adopted towards the Arab population should become a policy of repression. As I have already stated, the abolition of the Maghzen was the first mistake. No doubt these military police were frequently used by their Turkish masters as agents of oppression. But they kept the peace, and knew better how to deal with the tribes than did the French Generals who succeeded them. Entirely ignorant both of the nature and customs of the population, it is small wonder that they failed to pacify their new subjects. After the actual warfare had ceased, one unsuccessful method after another was tried, and grave injustice done, much more through lack of understanding than through malevolence.

The Moslem system which regulated the possession of land was extremely complicated. The vast domain of the Dey, including the richest part of the Tell, devolved automatically into the possession of the French Government. Besides these firstfruits of victory, there existed immense tracts of forest and uncultivated areas called Bled-elIslam, over which the neighbouring tribes enjoyed grazing and other rights. Then there were the 


\section{THE CONQUEST OF ALGERIA I 3 I}

Habous, or land belonging to religious communities, and the rest of the country was divided into two categories: Melk land, or that belonging to individuals, and Arch land or Sabega as it was called in the province of Oran, collectively owned by tribes or fractions of tribes.

Immediately after the cessation of hostilities, Algeria was inundated by a crowd of foreign speculators, whose object was to induce the credulous natives to sell their property for a tenth of its value. The scandal arising from these transactions was such that, in 1832 , sales were interdicted by order of the Commandant, and thus some portion of the Melk property remained in the hands of the original owners. This wise prohibition continued in force until the system of bestowing free concessions upon emigrants from France had exhausted nearly all the land at the disposal of the Government. Then began a series of expedients which reflect no credit upon the administration, and which were designed to oust native owners in favour of French colonists. Thus, by means more or less violent, the tribes were gradually dispossessed of a considerable portion of their territory. The instances in which they owned more than sufficient for their sustenance were rare, and in many cases they were despoiled of that which constituted their only wealth and means of livelihood.

These arbitrary measures were not accepted withK 2 
out protest by the Arab population. Their complaints reached the ears of Napoleon III, who evinced an intelligent sympathy with his Moslem subjects during the course of his tour in Algeria. The Emperor's disapproval of the policy then pursued doubtless inspired the idea of transforming Algeria into an Arab kingdom, bearing somewhat the same relation to France as our Crown Colonies do to the United Kingdom. Unfortunately, this project was strangled at birth by the fall of the Empire. But the law of the Senatus-Consult, promulgated in 1863 , survived, and it at least secured to the natives a legal right to the territory they occupied. The benefits it conferred were, however, to a great extent neutralized by the hardships attendant on the conversion of tribal, or Arch property, into Melk, or individual property. The system of collective ownership had existed from the earliest days, and was admirably suited to the habits of the people, the bulk of whom lost rather than gained by the division of the land among members of the tribe. Moreover, the difficulties of making the partition, with title-deeds vague or non-existent, were almost insuperable. It was far from being completed when the Kabyle insurrection of I87I still further complicated the relations between the conquerors and the conquered by reviving, in an acute degree, the old sentiment of hostility towards the native population. Its imme- 


\section{THE CONQUEST OF ALGERIA I 33}

diate result was the confiscation of large tracts of land, the closing of Arab schools, and a whole series of repressive laws and regulations.

Twenty-five years elapsed before this sentiment died out-not in Algeria, where it is as active as ever-but in the metropolis, where a more enlightened view of colonial questions had begun to animate French politicians. In 1897 it was decided to abandon the useless interference with tribal customs and operations of the Koranic law, which were responsible for the complete disintegration of Arab society as it had existed previous to I 830 .

When the idea of the Royaume Arabe fell with the Empire the institution of the bureaux arabes fell with it. But although the edict which suppressed this engine of government, established by General Bugeaud in I84I, stigmatized it as " anti-national," it was on the whole better adapted to the administration of the native population than the communes mixtes which superseded it, as the military gradually gave place to the civil authority. The commune mixte is an arbitrary territorial unit resembling the French arrondissement in size, and the whole seventy-five then created contained about seventy thousand Europeans drowned by nearly three million Arabs. Three other kinds of communes still exist in Algeria-the commune de plein exercice, where Europeans are in a large 


\section{I34 ASPECTS OF ALGERIA}

majority, the commune mixte $d u$ territoire $d u$ commandement, midway between the civil government of the north and the military region of the south, and the commune indigène, a collection of douars or Arab villages administered by a French mayor and a mixed council of soldiers and natives.

These microcosms are included in the three departments-Alger, Constantine and Oran, into which Algeria is divided. But, as Professor Girault points out in his masterly analysis of colonial legislation, these triplicate divisions are purely artificial, and correspond to no geographical or numerical necessity. Their towns are ruled by a series of préfets and sous-préfets, seconded in the rural districts by a host of administrateurs and minor officials, who endeavour to adapt to the heterogeneous population of a growing colony the complicated mechanism of a system transported from the metropolis. The history of its changes and ramifications would fill a volume. Suffice it to say that at the head of this elaborate organization is the Governor-General whose duties and privileges are more or less analogous to those of the Viceroy of India, save that he is directly attached to the Minister of the Interior in Paris, to whom his monthly reports are presented. The GovernorGeneral is assisted in the discharge of his functions by two public bodies, the Conseil Supérieur $d u$ Gouvernement and the Délégations Financières, 


\section{THE CONQUEST OF ALGERIA I 35}

both partially elective and compared by Professor Girault to the upper and low chambers of an Algerian Parliament.

That portion of the Sahara which has been slowly and painfully brought under the domination of France is described as the Territoires Militaires $d u$ Sud. Though technically within the limits of the Governor-General's sway, there is no question of modifying the military character of its administration. The defeat of Abd-el-Kader left the south practically unsubdued, in the hands of the powerful tribe of the Ouled-sidi-Cheikh. Tribal jealousy had prevented Si-Hamza, chief of the eastern branch, from making common cause with the Emir. But his son, brought up by a fanatical mother, set fire to the smouldering elements of unrest in 1864 . The insurrection spread after the massacre of a French column, and had not jealousy - the master-passion of the Arab-again intervened the whole Sahara would have risen. SiSliman, who ruled the Ouled-sidi-Cheikh of the west, then threw in his lot with the invaders. With his help the revolt was stamped out, at least temporarily, and the Oranaise desert kept quiet during the troubles in Kabylia, which broke out in $187 \mathrm{I}$.

The causes which contributed to fan the flame of war in the Sahara during twenty years of spasmodic insurgence were multiple. The untimely 
enfranchisement of the Jews was one of them; but there is little doubt that the death of imperial rule in France did much to undermine the faith of the Arabs in the power and prestige of their conquerors. What could the Republic signify to a race whose only conception of government was autocratic? It was natural that the word should leave them cold and rather contemptuous, and though experience has accustomed the natives of Algeria to the idea of new political forms, I am inclined to think that the absence of a personal sovereign considerably retarded the growth of their loyalty to the French flag. Those who had an opportunity of observing the devotion of the Indian population to the "Empress-Mother," Queen Victoria-a devotion which no dissatisfaction with her government ever dimmed-will understand what I mean. Only concrete symbols appeal, generally speaking, to the Oriental mind. Moreover, the theocracy of Islam is to any form of representative government as wine to oil. The incompatibility between their principles is not accidental nor even racial; it is inherent, as every student of political science knows. 


\section{CHAPTER VIII}

THE MOSLEM SUBJECTS OF FRANCE

When we say, as we often do, that France is not a colonizing power, we refer to her failure, so far, to realize that successful colonization does not invariably consist in replacing the native by the emigrant. On the contrary, in dependencies such as Algeria it consists chiefly in educating and developing the natives, so as to utilize to their utmost capacity the natural forces of the country. Our favourite reproach is now, however, in danger of becoming an exaggeration, for France is beginning to profit by her unfortunate experiences in various parts of the world. She is now about to embark upon a radical change of policy in regard to her African colonies. This change is, from our point of view, entirely for the better. M. Lucien Hubert, who has done much to inculcate a wider view of colonial problems in the minds of his countrymen, has admirably defined these new principles.

"From day to day," he writes in L'cuvre de la France dans l'Afrique occidentale, "we understand more profoundly that the real value of our colonies 
resides, not in their uncultivated wastes, but in their aboriginal inhabitants, formerly so despised. It is the population which makes the strength and riches of a country. The capital we should fructify therein is man, and this end can only be accomplished by rendering the man a finer fellow in his own eyes, by elevating the sense of his personal dignity, by augmenting his needs and providing him with the means of satisfying them, for this satisfaction is everywhere the object of human effort and the essential condition of happiness." Wise words these from the pen of the député for the Ardennes-words which are beginning to find their echo both in the councils of the metropolis and in the local government of Algeria.

Yet when we compare the condition of the Algerian native with the rest of the Moslem world, instinct everywhere with new life, it is impossible to avoid the conclusion that France has hitherto done little to further his development. This population, no less than this African soil, was to Rome and to Islam a source of strength and of riches. It not only nourished its foes, but it assimilated rapidly their habits and civilization. There is no reason to suppose that, given fair opportunities, they alone of all their co-religionists should prove refractory to the practical and intellectual culture of our day. But of the various levers which enable a race to rise the most potent 
is that of education, and until to-day educational facilities have been offered to the Arabs of Algeria with a very sparing hand. The GovernmentGeneral seems lately to have awakened to a sense of its responsibilities in this respect, and a sum of I $5,000,000$ francs $(£ 600,000)$ has been set apart to be expended over a period of twenty-eight years on the erection and endowment of schools for the enlightenment of native youth.

The provision of buildings and teachers is, however, only the beginning; less easy of solution is the problem of adapting the instruction to the needs and intelligence of the people. The plan adopted by the French differs in many respects from the system we have pursued in Egypt, where the primary instruction is given in Arabic, and is already extended to twenty-one per cent. of the population. In Algeria the system has been modelled upon that of the metropolis, and its tendency as a whole is to encourage the use of the French language. Official statistics for the year I 9I I give the number of free Primary Native Schools in Algeria as 374, and the total number of pupils as 36,220 . These figures appear infinitesimal in proportion to a population of nearly $5,000,000$. They are, of course, exclusive of the 2 I 3 students attached to the Medersas, or Moslem Colleges of Algiers, Tlemcen and Constantine, founded by the Administration to provide for the 
better class of natives a gratuitous education of a general and commercial character.

The last Annual Report indicates to a certain extent the lines upon which it is proposed to remedy the deficiencies of the present system. Each year eighty new schools are to be created, many of which will supply the simplest form of primary instruction, and will be situated in the heart of the rural districts. To these native teachers will be appointed, subject to periodical supervision, but for the towns, whose inhabitants frequently number several thousands with no existing school, French instructors will be chosen. An effort will be made to educate as well as to instruct the native mind, to mould the character at the same time as the intelligence, and also to vary the curriculum according to the exigencies of the several provinces where conditions of life and population differ considerably. The first step towards the realization of this programme is to train the teachers, and many years must elapse before the result of these enlarged opportunities will be evident in the next generation of Algerian natives.

Much more has hitherto been accomplished by the French Administration towards improving the health of their Moslem subjects. At the present day four hospitals and eighty-one infirmaries, comprising 1424 beds, exist in Algeria for their exclusive benefit, besides a large staff of medical 


\section{MOSLEM SUBJECTS OF FRANCE 14I}

officers of both sexes, who give free consultations in all the towns in Tell and also in many villages of the High Plateaux. The Arab, like all the poorer classes of Orientals, is totally devoid of hygienic knowledge; and as his religion leads him to ascribe all afflictions of the flesh to the will of Allah, it is not easy to induce him to acquire habits calculated to prevent the spread of illness in the douars. Ophthalmia is almost as universal in Algeria as in Egypt, and one of the chief preoccupations of the medical officers is to distribute boracic acid and to see that it is used. Many of the assistant officers are natives, and every encouragement is given to those desirous of qualifying themselves for the work of healing their suffering compatriots. Apart from these benevolent institutions, the creation of Mutual Benefit Societies is also teaching the native to help himself by imitating the saving customs which are so largely responsible for the wealth of France. The fact that the funds of the Sociétés Indigènes de Prévoyance amounted in I 9 I I to nearly $21,452,000$ francs $\left(£^{8} 5^{8}, 000\right)$ will give some idea of the influence they have gained over the naturally improvident Arab mind.

One of the greatest disabilities under which the Moslems of Algeria still labour is the anomaly known as the "Code de l'Indigénat." In virtue of this ordinance, a native can be arrested and im- 
prisoned practically without trial, at the will of the administrateur for his district. However well-disposed these functionaries may be, such an accumulation of judiciary and administrative powers in the same person is calculated not only to lead to grave abuses, but to breed a feeling of insecurity in the whole Arab population. Through the influence of M. Albin Rozet, député for the HauteMarne, who has devoted his energies for many years to increasing the welfare of natives in the French colonies, a commission was recently appointed by the Chamber of Deputies to study the question of the "Code de l'Indigénat algérien."

Its recommendations include the total abolition of the present system, and the trial of natives, accused under the seventeen counts mentioned in the Code, by the ordinary tribunals. As the term of these enactments expired last year, it is to be hoped that the reform advocated by the Commis sion will shortly be adopted. I may add that an examination of official statistics does not confirm the supposed need of special legislation to restrain the criminal tendencies of the natives. As a whole they are far less turbulent than the European population, the Spanish section of which must be held responsible for the majority of crimes against the person committed in Algeria.

The operation of the "Code de l'Indigénat" is not, however, sufficiently oppressive to account for 


\section{MOSLEM SUBJECTS OF FRANCE I 43}

the fact that numbers of Arabs, notably in the province of Constantine, have recently deserted their native land in the hope of obtaining more favourable conditions in Syria. Divers causes have doubtless contributed to bring about this exodus. It has certainly been encouraged by unscrupulous emigration agents, who have persuaded the ignorant fellah that he will find a new heaven and a new earth under the Turkish flag. Nor is the French colonist entirely innocent of complicity in this deception, which enables him to purchase the land of the intending emigrant at his own terms.

I had an opportunity during my sojourn in Algeria of discussing this situation with an intelligent Arab whose acquisition of European learning has not alienated his sympathy from his less fortunate compatriots. He interpreted this flight as a sign of despair; the manifestation of a feeling growing up in the fellah that the fiscal inequality of which he is the victim renders hopeless any attempt to keep pace with his French neighbours who are similarly engaged in the cultivation of the soil. That the native population bears an excessive proportion of the taxes is universally admitted beyond the frontiers of the colony. The imposition which presses the most heavily is the exorbitant land-tax-the achour and hockoramounting to frs. $5^{\circ} 5^{\circ}(4 s .5 d$.) per hectare 
(approximately two and a half acres), from which the French settler is totally exempt. "Of what use," remarked the Sheikh, "is it to encourage the fellah to employ modern agricultural implements and methods when the burden of the landtax prevents his reaping the benefit of increased production? His struggles under this disadvantage are unavailing, so he either falls into the hands of the usurer, who ends by foreclosing on his fields, or he decides to abandon them to his rivals and seek fortune elsewhere."

The unification of the land-tax in Egypt was the signal triumph of Lord Cromer's administration. In Algeria it constitutes a grievous load, borne exclusively by the native inhabitants, who annually contribute over frs. I8,000,000 $(£ 720,000)$ of the whole taxation. This sum represents, in other words, a levy of frs. 7 ( $5 s .7 d$. per head. In France itself, the richest country in Europe, the land-tax does not represent quite frs. 6 per head of the population.

The injustice of compelling the indigent Arab to supply the revenues which are spent without his sanction on the comparatively prosperous colonist is beginning to arouse indignation among French writers on colonial affairs. In a recent series of articles the Temps urged the Metropolitan Government to reform a system of taxation which, as it stands, can only serve to engender racial 


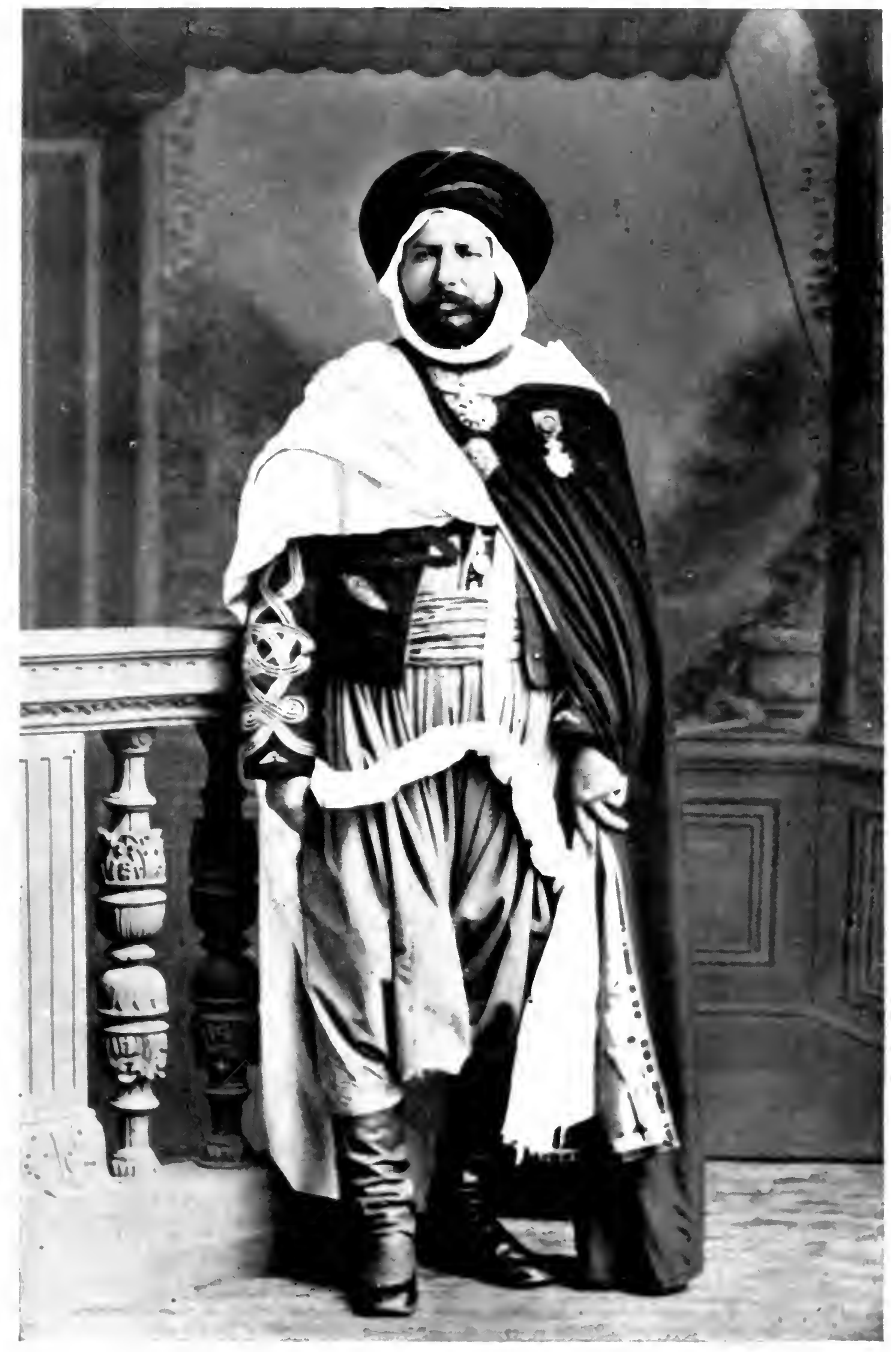

CAPTAIN MOHAMMED BEN-DRISS, HX-AGHA OF TOLGGOURT 

antagonism and to render nugatory other benevolent schemes for improving the condition of the Algerian native. "According to our principles," reiterates this well-informed correspondent, "it is unjust that a native should be taxed to the extent of fifty or sixty francs on the little field he sows, while the European or Jewish proprietor of hundreds and sometimes thousands of hectares pays nothing whatever. According to our principles, it is unjust that the section of the population which furnishes the greater part of the budget receipts should not obtain an equivalent share in their allocation. And as we do not keep them in their primitive ignorance, the natives are becoming more and more alive to this inequality. For this reason, we repeat, it is useless to educate the native as long as we maintain this reign of oppression. If we continue to do so without mending our fiscal ways, a catastrophe of some sort will be the inevitable end."

This is strong criticism, but it is also well merited, for it is obvious that the Algerian colonist no longer requires the process of dry-nursing which called him into being. If collectively he is able to spend in one year frs. $28,508,000$ on 2,974 automobiles, as the customs returns testify, he can scarcely continue to plead that poverty which justifies exemption from a land-tax that is crushing out of existence the Arab cultivator. Moreover, 


\section{I46 ASPECTS OF ALGERIA}

if an augmentation of the absurdly low duties on alcohol and tobacco should permit a reduction of the present burden on the land, the health of the European community would benefit as much from the change as the pocket of the Arab.

Apart from the tax on the soil itself, the native pays on the number and nature of his flocks. The Zekkat, as this imposition is named, exacts four francs for a camel, three francs for a cow, while sheep and goats contribute twenty and fifteen centimes respectively. In Kabylia another imposition, called the Lezma, is in force. This is a kind of poll-tax, which in the south usually falls upon the palm trees instead of upon the owner himself. Nor does it complete the list. Like the Egyptian fellah before the British occupation, the Algerian Arab is subject to corvées of all kinds, such as the transport of official stores, the policing of the forests and even occasionally of the towns.

Hand in hand with the project of increasing educational facilities is another, also conceived with the intention of lessening the distance that at present divides the Moslem population of Algeria from their foreign masters. It is proposed to extend to the Arabs the principle of obligatory military training. Opinions in France, as well as in Algeria, are singularly divided as to the wisdom of this scheme. It has been subjected to adverse criticism, not only from officers of the French 
Army who have had years of experience in the Sahara, but also from such eminent students of contemporary colonial history as M. Leroy Beaulieu. On the other hand, the plan has found enthusiastic advocates in both camps, among others the Commandant Chardenet, who has been largely instrumental in formulating these proposals; $M$. Messimy, ex-Minister for the Colonies, who has advocated their adoption in the Chamber of Deputies; and M. Luciani, the able Directeur des Affaires Indigènes.

In a conversation I had with the latter a short time ago he expressed his approval of the plan. Although he admitted that the moment was rather inopportune to put it into practice, he ridiculed the idea that its application could ever become a danger to French supremacy. In any event it is the intention of the Government to proceed with caution. Not more than I,560 men will be called annually during the first ten years out of the 46,747 enrolled as suitable for military training by the recent census. After ten years it is proposed to train 5,000 men a year; so that in twenty years' time Algeria should furnish to the national forces a contingent of 100,000 men. M. Luciani did not anticipate any serious resistance on the part of the Arabs, in whom the love of war is instinctive, if at present dormant, and the petition recently presented to the French Premier in Paris by a delega-

L 2 


\section{ASPECTS OF ALGERIA}

tion of Algerian natives confirms this opinion. The protests contained in this document are not directed against the principle of military service, but against the conditions under which it is proposed to recruit the Arab contingent. Speaking for the mass of his co-religionists, Dr. Bentami expressed their willingness to respond to the call of France. Nor do they desire to receive the bonus of frs. 250 to be offered as a compensation for the imposition of this new burden. They ask instead that it should coincide with the adoption of reforms which they have long demanded-such as the equalization of the land-tax, the abolition of the special penal code, and above all the extension of native representation in the legislative assemblies of the colony and the metropolis.

Some further grant of political privileges is, in fact, an almost inevitable corollary of the application of this project, which has for this reason encountered far more strenuous opposition from the French inhabitants of Algeria than from the natives themselves.

If a sword is forced into the hand of the Arab, it follows that he must also be given a vote; not immediately, perhaps, but eventually. This is a maxim which scarcely admits of discussion. It is no longer possible, even if it were advisable, to claim from a subject, whatever his race or colour, the duties of a citizen without bestowing upon 
him a citizen's privilege. The attempt to do so cost us America, and a similar essay could not be seriously contemplated by Republican France. But the prospect of enfranchising even 100,000 natives is, to say the least, disquieting to the colonist, who generally detests his Arab neighbour, regarding him as an enemy whose interests are diametrically opposed to his own.

Nor does he contemplate with any greater equanimity the prospect of these rivals whom he has displaced being trained in the use of arms. In the last edition of his stupendous work, M. Leroy Beaulieu gives expression to this sentiment which he shares: "I am not afraid to assert," he writes, " that in adopting the project in question we are simply risking the eventual loss of our Northern African possessions." "With prodigious naïveté," he concludes, "the French imagine that the Arabs and Kabyles are satisfied with our domination; but the truth is that many generations must elapse before the majority of our Moslem subjects relinquish in their dreams the hope of throwing the French and all other foreigners into the sea, or at least of emancipating themselves from our rule."

The fact that the recruiting of the natives for purposes of home defence has worked very well in Tunisia is an argument frequently used in favour of subjecting the Algerian Arabs to the same military training. But as far as the indigenous popula- 


\section{0 \\ ASPECTS OF ALGERIA}

tions are concerned, there is no possible comparison between the two countries. The Tunisian is still in the enjoyment of his own land, with his privileges scarcely curtailed, under the protection of a foreign power - the same power whose presence in Algeria is the result of a long series of military struggles, with their attendant ruin and bloodshed. Although there are at present no signs that the memory of those events remains green in the minds of the Algerian Moslems, it is idle to suppose that they have grown to prefer a condition of dependence to one of freedom. For the moment the Arabs have renounced the hope of liberty, but circumstances might easily revive that hope, especially if those circumstances seemed to render its realization possible. The next generation of Arabs will have become, to a certain extent, europeanized. They will possess the advantage of a French education, and many of them will presumably seek an outlet for the employment of their newly acquired knowledge. This problem we have had to face in India and in Egypt, and the solution is still to seek! What will the French Administration do with the Arabs of the future who, if the present intentions of the Government are carried out, will be not only educated men, but - in some proportion at leasttrained soldiers and enfranchised citizens? So far the measure of political rights extended to them 
has been so small as to be practically negligible. Since 1898 four native members are elected to the "Conseil Supérieur du Gouvernement" out of a total of sixty. In the same year another organ of administration was created, called the "Délégations Financières," and in this case a larger proportional representation was permitted. Of the twenty-one Arab and Kabyle delegates, fifteen are elected by their compatriots; and although, as against fortyeight delegates representing the French colonists, those defenders of native interests are powerless, an opportunity is thus afforded for the ventilation of grievances and the expression of Moslem opinion on any proposals which may concern them. This chance of making themselves heard is not, in any degree, comparable to the privilege of universal suffrage enjoyed by every French citizen, and which an Arab can attain by naturalization.

That course involves, however, the loss of his personal status under the Koranic law, which still regulates marriage customs and transmission of property for every Moslem. It is not surprising, therefore, that only a few have hitherto availed themselves of this means of becoming an elector ten years after the event.

Nor does the educated Arab even aspire to full enfranchisement for his whole race. The demands formulated in the petition I have already referred to fall far short of universal suffrage. An enlarge- 


\section{I52 ASPECTS OF ALGERIA}

ment of the electoral college which would secure to them a two-fifth proportion of the number of delegates in the Colonial Assembly would content the most ambitious, provided that this reform were accompanied by the establishment of an Advisory Council sitting in Paris to be composed of Arab notables elected by their co-religionists in Algeria. Such a measure of representation can scarcely be called excessive, nor likely to endanger the interests of the colonist, who is apt to regard the ignorance and subjection of the native community as a necessary condition of his own welfare, and who systematically opposes any attempt on the part of the Government-General to mitigate either the one or the other.

As an instance of the hostility of the average colonist towards his Arab neighbour take the commune mixte of Mirabeau, where 299 French citizens govern 7,957 natives. Not only does no school exist for the instruction of the latter, but when the native inhabitants requested authorization to open one at their own expense the application was refused by the municipality on the grounds that it disapproved of the education of the Arabs! In the election of the mayor and of the town council the Moslem population, although in a vast majority, does not participate, and he is in consequence indifferent to its needs. Possibly a certain shrewdness as well as indifference entered 


\section{MOSLEM SUBJECTS OF FRANCE I 53}

into the decision of the municipality of Mirabeau, for the submission of the natives of Algeria to oppression of this kind is not likely to outlive their illiteracy.

Fortunately for the future of France as a great colonizing power, these prejudices find no echo in the words of statesmen or writers in the metropolis. Indeed, the injustice of entrusting the representation of half a million Arabs to the six deputies and three senators elected by, and dependent on, a relatively small number of colonists is apparent, especially when it is realized that those electors are largely composed of the mixed inhabitants of the towns, who frequently possess neither property in the colony nor even an adequate knowledge of the French tongue.

So far the race problem in Algeria has been confined to the relations between the European and the Moslem populations. The future may, however, add a tertium quid to the situation in the name of imperial defence. With a declining birthrate, France can ill afford to devote an army corps of 50,000 men, for the purpose of protecting Algeria against possible internal disturbance, as its proximity to a French military base renders provision against external aggression superfluous. The desire to release the metropolitan contingent gave birth to the idea of training the Arabs as a 


\section{54 ASPECTS OF ALGERIA}

substitute for the present troops. But the proposals for devolving the defence of the African colonies upon their aboriginal inhabitants does not end there. The negro millions of Senegal and the Sudan are just as susceptible of receiving military instruction as the Arabs. According to Colonel Mangin, who is to some extent the father of the scheme to utilize them also, France could thereby dispose in the course of a few years of a contingent of 70,000 black soldiers, capable of protecting not only the frontiers of their native land, but of keeping order in Algeria as well. This negro force once organized, the Nineteenth Army Corps would be free to transfer their battalions from Africa to the north-eastern boundary of France.

Nothing could sound better in theory than this ingenious plan of arming the blacks for the control of the Algerians. But if we are to listen to such critics as the General de Torcy and others who are acquainted with African conditions of life, nothing could be more perilous in practice. In one form or other the expedient of using black troops has been successfully tried in most of our British dependencies. The four Sudanese regiments in Egypt are imbued with a military courage and discipline which the fellah will never emulate. The militia which has replaced the imperial garrison in tropical colonies such as British Guiana and Mauritius is almost exclusively composed of 
MOSLEM SUBJECTS OF FRANCE I 55

negroes. But these native contingents were formed for the exclusive purpose of defending home and country, and for this task they are well adapted and efficient. But to transport them into a foreign country - and to the Senegalese Algeria is just as foreign as France-to police and protect a foreign population is an innovation which has never occurred to the most rabid political opportunist in Great Britain. When, during the Transvaal War, the suggestion of sending a native contingent to South Africa emanated from India, it was rejected by the War Office on the grounds that such action would transgress the code of civilized warfare.

It is difficult to believe that France seriously contemplates putting into execution a project immeasurably more dangerous to the peace of Algeria than that of training and enrolling the Arab. The disadvantages of that plan are trifling when compared to the objections which may be urged against this device for the fulfilment of an imperial duty. If anything could inflame the Moslem population of Algeria into definite hostility it would be to place negroes, whom they still regard as slaves, on guard over them. That consideration alone should suffice to condemn the idea. Other risks which it would involve are, however, evident, notably that of introducing those terrible tropical maladies from which the Sudanese 


\section{I56 ASPECTS OF ALGERIA}

negroes suffer into a colony which has hitherto been exempt from them.

The hour has evidently struck when France will have to reconsider, as we have had to do elsewhere, her attitude towards those indigenous multitudes whose destinies it is her mission to shape, and whose aspirations it is her duty to guide into some avenue of harmonious development. Concessions to native sentiment in the matter of political representation, and the redress of various obvious wrongs in Algeria, will help but not wholly elucidate the problem. Nothing but time can do that. But if it is futile to prophesy, it is equally futile to ignore essential factors in human nature, subject as much to the law of heredity as to the influence of environment, which persist in spite of all efforts to eradicate them. The Arab brought into ever closer contact with Occidental thought and conditions may-indeed, must-lose in the process many of his present characteristics. He will exchange the beauty and grace of the burnous for the hideous apparel of the West; he will adopt its pathological activity and its innumerable needs. Almost inevitably he will cease to regard the Koran with the passionate and unquestioning faith of the past. But it does not follow that in ceasing to be a Moslem he will become a Frenchman. The renascence of Turkey, the agitation in Egypt and in the Farther East seem to indicate quite another 


\section{MOSLEM SUBJECTS OF FRANCE I57}

line of development of which there are already signs in Algeria. The spirit of nationality abroad in the Eastern as well as in the Western world may well infuse into what remains of the old tribal instinct a new and larger solidarity. In that day the cry of "Algeria for the Arabs" may echo across the Desert to the Tell.

Do not let us console ourselves, however, with the reflection that if any future consolidation of the Islamic races into separate nationalities should result in the expulsion of the French from Algeria, Tunisia and Morocco, our tutelage of Egypt could continue. European domination of Northern Africa will stand or fall as a whole. Our interests in that continent are one and indivisible, however the efforts by which we each seek to advance and serve them may differ in detail. They are the interests of Western civilization, with all that it entails. We can no more afford to be indifferent to the relations of France with her Moslem subjects than she can disregard the trend of our policy in Egypt and in India. Although we must each face the same problem in our own way-a problem necessarily modified by local and historical conditions-no thinking person can avoid the conclusion that, in the not far distant future, those several problems will have resolved themselves into one. The issue will then be not between France and the 
Algerian natives, or between England and the Egyptian Nationalists, but between the West with its traditions and the East with its awakened energy. Whether that struggle can best be retarded by the concession of larger liberties to those Oriental races who still remain under our influence, or by attempting to bridge, through a gradual unification of their interests and aspirations with our own, the gulf which is only typified by the colour of skin, constitutes the only difference between French and British Colonial policy. Not the least valuable aspect of that sympathy which now unites us to our neighbours is the disposition, equally manifest on both sides of the Channel, to learn from each other's experience in dealing with strange peoples, and to evolve a Colonial policy which will include the wisest elements of both systems of government. 


\section{CHAPTER IX}

THE COLONIZATION OF ALGERIA

Volumes might be filled with the vicissitudes which have attended the cultivation of the Algerian soil since the date of the conquest, when the idea of displacing the native population by the importation of French settlers first occurred to the military commanders. Until I 860 gratuitous concessions of land were granted to any Frenchman who could be induced to accept them. Some of these pioneers were soldiers who had come to fight the Arabs, and who were persuaded by General Bugeaud to enter in and possess the territory so tentatively won by the sword. Many were just unsuccessful citizens of the metropolis, without experience or capital, who, as Governor 'Tirman complained, had proved their general incapacity, and so thought they might as well emigrate. The majority of these adventurers retraced their steps as soon as they discovered that Algeria was not a land overflowing with milk and honey. But some few remained till the failure of these early attempts was rendered complete by the rebellion of Abd-el- 
Kader, which again converted the plain of the Mitidja into a shamble.

When a tranquillity that possessed none of the other attributes of peace was re-established, the vicious system of free concessions was somewhat modified in favour of sales by auction of the more desirable portions of the official domains. But the excellent results attained by this method of colonization were mitigated by the vexatious restrictions imposed upon the purchaser. In the case of gratuitous grants the conditions were still more onerous, and contributed to the lack of success which attended most of these efforts. The colonist was compelled to build his house where the administration desired to create a village. Isolated dwellings were prohibited, as was individual choice in the matter of cultivation. He had to sow the grain officially ordained, and to live in every sense of the word according to rule.

This grandmotherly administration was not only unsatisfactory for the colonists, as a class men of independent tastes, but extremely expensive as well. The 234,375 hectares $(578,906$ acres) of land confiscated, and the 87,291 hectares (2 I 5,608 acres) acquired by expropriation after the suppression of the rebellion in $187 \mathrm{I}$, resulted in a revival of free concessions, and during the twenty-four years which terminated in 1895, I3,301 French families were established on Algerian soil. Of 


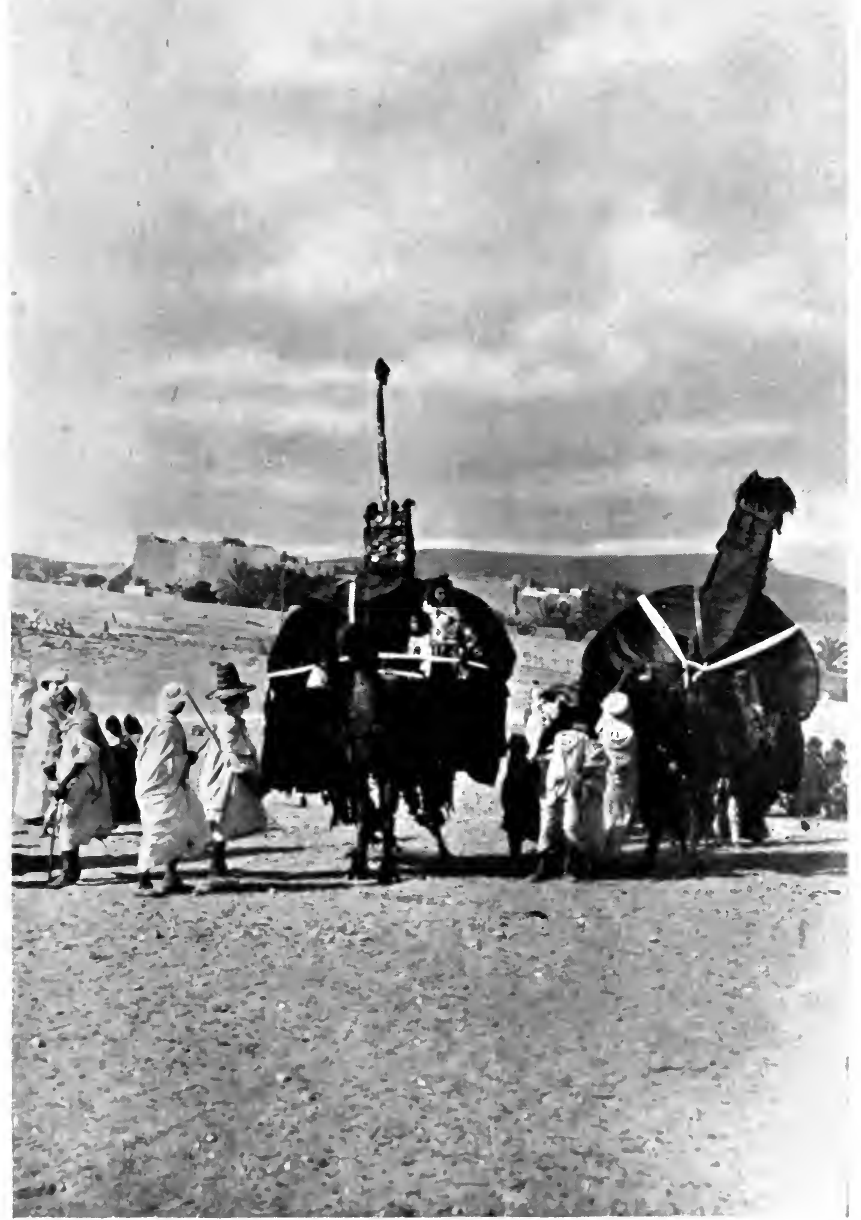

AN ARAB CARAVAN 



\section{COLONIZATION OF ALGERIA I6I}

these only 5,184 families still remained in I90 on the land which had been given them. In the following year that number was increased to $6,35^{8}$, each family having cost the Government upwards of 12,300 francs $(£ 492)$, or about 3,600 francs (£I I4) per person. When it is added that a certain proportion were naturalized foreigners, the extravagance of such a system becomes even more evident. These figures, taken from an official report prepared in 1906 by M. Peyerimhoff, Director of Agriculture and Commerce, and a convinced advocate of official colonization, are not open to doubt.

In his work before referred to, M. Leroy Beaulieu deals exhaustively with the different methods by which emigrants are induced to settle in a foreign country. He unhesitatingly condemns the principle of free concessions, and regrets that the sale of State domains, adopted in Algeria when the supply of land was running short, has not entirely replaced it. This plan of selling allotments, both at a fixed price per hectare and by auction, has worked very well in Canada, and is a simple and justifiable means of replenishing the Colonial Treasury. It constitutes, together with light ad valorem duties, the chief source of revenue on which a growing colony can rely. Nor would it seem impossible to achieve in this manner the object which these grants were designed to attain 
- the increase of the French element in the population of Algeria.

With the gradual settlement of the country, and consequent security for life and property, the colonist has increased in numbers and prosperity. But the greatest difficulty with which he has to contend is the essential difficulty of a climate subject to great extremes of temperature and too abundant rains succeeded by too long periods of drought. In order to understand the problems which confront the rural inhabitant one must begin by examining the physical features of this northern boundary of the African Continent.

The narrow belt of land which borders the sea, whose temperature is equalized by its contact, is called the Tell, and constitutes the most fruitful region of Algeria. It is edged on the south by the broken line of the Atlas Mountains, which stretch in a double chain all along the coast from Tunis to Morocco. Between their northern peaks and those that overhang the limitless expanse of the Sahara is a table-land of varying height frequently as much as two hundred miles wide. In the valleys that cleave these mountains and on their lower slopes the climate is still sufficiently temperate for the culture of cereals. To this region belongs the extensive corn-lands of the province of Constantine and the plains of the Mitidja. Ascending from this cultivated level 


\section{COLONIZATION OF ALGERIA 163}

we reach the High Plateaux. This name is given to the vast wind-swept steppes which are, at an average altitude of 800 metres $(2,625$ feet), intersected by chotts, or salt lakes, and pierced by the higher ranges of the Djurjura and the Aures. Here no culture is possible in spite of the efforts of the Administration. Pasture for the innumerable herds that traverse them on their way to the markets of the Tell is all that the High Plateaux will ever contribute towards the sustenance of man. Some idea of the number of these may be gathered from the Statistique Agricole for I910. According to its calculations the Arabs own over nine million head of cattle and sheep as against the $85^{8,000}$ possessed by Europeans.

To the south, beyond the frontier wall of the Aures, is the desert, with its leagues of naked sand. Thus it is evident that only a fraction of the whole colony is susceptible of agriculture-a fraction which reaches, however, 3,5 12,635 hectares $(7,781,587$ acres $)$ in extent. Of this total about $1,007,417$ hectares $(2,518,542$ acres) is cultivated by Europeans, the rest being still in the hands of the Moslem population. By far the greater part of this arable territory is consecrated to the growth of cereals, which in the form of wheat, barley, maize and sorgho cover already over 3,000,000 hectares (7,410,000 acres), and in the plains of the Cheliff, the Mitidja and the M 2 


\section{I64 ASPECTS OF ALGERIA}

Seybouse very profitable crops are raised by the application of scientific methods.

The culture of oranges is also practised, but as it requires considerable capital and abundant water its area cannot be indefinitely enlarged. It costs from $£$ I 20 to $£$ I 60 to plant a hectare-nearly two and a half acres-of three-year-old trees which only bear fruit five years later, and in districts exposed to much wind cypress hedges are necessary to protect the young shoots. Thus the orange will never grow into a rival of the vine, which covers I 52, I 29 hectares $(380,322$ acres) of the richest land in the Tell. The fortunes of these vineyards have, however, varied considerably since the first visitation of phylloxera brought temporary ruin to the French viticulturist. In I 903 every rood of available land in Algeria was consecrated to the grape. When, however, the mother-country had conquered the disease by planting vines which science had rendered immune, Algerian wine was driven out of the market. The vineyards of the Tell, costly to plant and costly to cultivate (about $£$ I 2 to $£$ I 4 a hectare), were soon struggling under the weight of a mortgage, which by 1909 had reached the sum of fifteen millions sterling. A year later, however, this gigantic liability was swept away by the almost total failure of the grape harvest in France which has again brought prosperity to the colonial grower. Never has Algerian 


\section{COLONIZATION OF ALGERIA I 65}

wine been so abundant or the price so high as in I 910 and the following year.

During I9I I alone 207,698,000 francs $(£ 8,307,420)$ worth of wine was exported by the I 3,20 I European viticulturists, figures which work out at about i 5,600 francs $(£ 624)$ per head. The wine is not bad in quality - a good deal of it, such as that produced in the old monastery of $\mathrm{La}$ Trappe, is excellent. But it is, on the whole, inferior to French wine, of which there is in normal seasons an over-supply, therefore some diminution of the present enormous demand is to be anticipated. There is reason to fear, moreover, that the incorrigible parasite may avenge its expulsion from France by making its home in the colony. Each year its ravages have spread, but never so fast as in the last two years. Indeed, it is estimated that sixty-six per cent. of the Algerian wine-lands have, in a greater or less degree, fallen a prey to the plague. Wise proprietors are devoting the profits of the recent boom to the work of replanting with American vines, of which $52,727,248$ plants were imported during 1910, and the Government-General is now offering its co-operation so that the eradication of the tainted vines may be extended and the pest defied over a wider area than before.

In 1906 Algerian wine was introduced into the English market. But although we absorb a larger 
quantity every year- 15 I,646 gallons in I909our consumption is much inferior to that of Switzerland, Belgium and Germany. According to the opinion of French wine merchants in London, the wine best suited to the British palate is "a light wine of ordinary colour with eleven to twelve per cent. of alcohol." As the treatment of new wine is not understood in our country, and the average Englishman lacks the necessary accommodation for storing in the wood, only wines insusceptible of fermentation are fit for export to the United Kingdom.

There is something painfully incongruous about a religious retreat suddenly diverted to secular uses. Even persons who avow no sympathy with the monastic ideal are conscious of a certain sentiment clinging to places whose walls have echoed for centuries to the accents of prayer. The spectacle of modern activity invading an immemorial silence drew me one June afternoon to the old monastery at Staoueli. After the extension of the Law of Separation between Church and State to Algeria, it was sold by the Trappist proprietors to a Swiss colonist, who has had the wisdom to leave the abbey intact. The cloister, with its simple Gothic arcade, still encircles a garden rosy with oleanders and geraniums. Wooden cells still line the long dormitory, and the fragments of statuary and Latin texts still linger over doors and along 
the grey walls. The chapel, bare of all decorations, retains its dividing screen which separated the white-robed Fathers from the brown Lay Brothers. They counted I IO in all on the day when they embarked for Italy, shaking the dust of Africa from their worn sandals-that Africa wherein most of the heresies were born.

The brother-in-law of the present proprietor, who manages the farm, was kind enough to show me how the wine is made. It is more abundant now, if not finer in quality, than that which the monks produced, for the improved installation turns out 30,000 hectolitres, or 660,000 gallons, yearly. The wine, which is almost exclusively red, is all made during the month of September. In the actual making only fifteen men are employed since the new method of production was inaugurated. The process is simplicity itself. After weighing the grapes, which are brought in carts from the vineyards, they are thrown into a revolving cylinder that separates the berry from the stalk. This done, the fruit is pressed through pipes into a series of vats, where fermentation takes place within about five days, at an even temperature of $32^{\circ}$ Reaumur. Thereafter the wine is kept in huge amphoras of glass encased in concrete, each of which contains i 50 hectolitres $(3,300$ gallons). Before it is sent out the contents of the various vats are mixed in a machine called an 
" equalizer," so as to secure uniformity of quality and flavour. Another plant destined to increase the white wine output is in process of construction.

The bulk of the grapes used are grown on the Abbey farm, the rest being bought from small farmers in the vicinity. Of the 1,250 hectares (3,087 acres) at La Trappe, a few hectares are still devoted to the culture of early vegetables and geranium, whose essence is distilled just as it was by the monks. This essence is the basis of nearly all perfumes, and paid very well before the geranium was planted in the Isle of Réunion, from whence it is now exported and sold in Grasse. at a price with which Algeria cannot compete. The thirteen million olive trees, most of which find nourishment on the slopes of the Kabylia Mountains, produced, in 1910, 3,364,092 quintaux of oil.

Among the subsidiary kinds of culture, which include lemons, almonds, cherries, pomegranates and figs, early vegetables occupy an important place. All along the littoral this intensive gardening is practised, chiefly in the neighbourhood of the ports, whence tons of potatoes and forced vegetables are shipped to stimulate the jaded appetite of Paris. These small farms are almost exclusively owned and cultivated by Spaniards and Italians. An idea of the extent of this industry can be obtained from the customs returns 
for I9II, which register an export of potatoes, primeurs, and grapes, to the value of over I $5,000,000$ francs $(£ 600,000)$. Two crops a year can be raised in the gardens of the Tell; the first sown with the September rains, the second in early February. The profitable character of this culture and the development of the mines continue to attract large numbers of foreign emigrants, who monopolize both these kinds of employment.

The optimistic predictions as to the future of tobacco in Algeria have unfortunately not been realized. In the case of this product, as with the vine, the superiority of the demand to the supply, due to external causes, has led to over-production. The high prices current in 1907 and 1908 induced many agriculturists to plant tobacco where they had formerly planted cereals, with the result that the crop of 1909 reached a total of $12,400,000$ kilos (12,204 tons), or nearly double that of previous years. At the request of the GovernorGeneral the Régie came to the rescue and increased the amount of its purchase, which represents about 3,000 tons annually, but low prices and a limited market had spread discouragement among the growers, and during 19 Io and the following year their number had sunk from 21,503 to 12,026.

The system of cultivation is somewhat similar to that employed in the date-culture of the South. The actual work of production is done by a native 


\section{I70 ASPECTS OF ALGERIA}

farmer, or khammes, who receives from the proprietor of the land a third of the crop in payment for his labour. In spite, however, of these blighted hopes, there existed at the close of I9I I eightytwo tobacco factories in Algeria. But the quality of the tobacco is as yet far inferior to the tropical weed, and the Régie, being a government monopoly, has naturally a wide field for selection.

Equally optimistic, though with more justification, are the advocates of the culture of cotton in Algeria, an enterprise which is still in the experi. mental stage. Cotton was, however, grown by the Arabs before the French conquest, and was revived with great profit to the colony during the years that followed the War of Secession in America. But when this temporary demand fell off the culture was gradually abandoned until a few years ago. The new possibility that cotton might come to mean to Algeria all that it means to Egypt has induced the Government to offer every encouragement to those who are again attempting to acclimatize the plant. The greatest enemy of the scheme is the rainfall, which usually takes place in September in the Tell, the only region where winter frosts do not prohibit any hope of success. The latest official reports are extremely sanguine, and as they are founded upon figures one cannot dismiss them as the expression of unwarranted enthusiasm. The average profits per hectare 
obtained in America are quoted by official returns at frs. 165 ( $6_{6}$ I2s.), and in Egypt at frs. I ro $\left(£_{4} 8 s.\right)$. In comparison with these figures the success which has rewarded the efforts of planters in the Cheliff-where profits of frs. 340 ( $\mathrm{I} 33 \mathrm{r} 2 s$.$) to frs. 770(£ 30 \mathrm{r} 6 \mathrm{~s}$.) per hectare have been realized-seems to indicate a brilliant future for cotton in Algeria. The industry already possesses an association which furthers its interests at Orléansville, and the favourable expert opinion of M. Charles Brunel has had the effect of enlarging the area under cultivation. Experiments in dry culture have recently met with success, and it is possible that the growth of Mississippi and Egyptian Mitafifi cotton may ultimately surpass the well-watered temperate zone.

It is unlikely, however, that any of these exotic products will seriously rival the culture of corn which has been practised since ancient days in this colony, and which represents to-day in the list of exports an average annual sum of $70,000,000$ francs $\left(£^{2}, 800,000\right)$. It is to be hoped that science and capital combined will succeed in alleviating the irregularity of the crops due to the eccentricities of the climate. In this prolonged fight with Nature the Government Department for the encouragement of agriculture has rendered great assistance to the colonist. Although little or nothing has as yet been done, either to 
preserve the rainfall or to combat the drought by means of irrigation, experiments in "dry farming" have been carried out on a large scale and at different altitudes. The botanical branch of the department has also laboured for the past seventeen years with a view to isolating those varieties of wheat best adapted to the climate. So far repeated trials seem to have demonstrated the superior drought- and rust-resisting properties of the "Pelissier" seed. Artificial manure is not yet sufficiently used as a corrective to the inevitable exhaustion of the soil, and the expense unfortunately renders this expedient impossible to any but the large landowners.

As a chronic insufficiency of water constitutes one of the greatest obstacles to Algerian agriculture, it is astonishing that no effort has yet been made to introduce and organize a comprehensive system of irrigation. From time to time considerable sums have been ear-marked in the budget for the construction of isolated reservoirs and other works, but their utility has been limited where they have not entirely failed through being built in the wrong place or in the wrong way. With his unerring judgment the late GovernorGeneral, M. Jonnart, realized the necessity of developing this branch of public enterprise, and he made an attempt to secure the co-operation of the more prosperous colonists in a scheme from 
whose realization they would be the first to benefit. But the Algerian farmer has been so long accustomed to depend upon the Government for every amelioration of his lot, that none were on this occasion disposed to share in the task of providing Algeria with the elaborate series of barrages and canals of which she stands in need. So M. Jonnart's project was lost to the parched earth like the capricious rainfall in the Tell; or rather it awaits the day when some energetic landed proprietor will perceive that more water means richer harvests. With the aid of a Treasury guarantee, it ought not to be impossible to carry out irrigation works on a scientific plan, such as those which have so enormously augmented the agricultural prosperity of both India and Egypt. In India the Punjaub canals and the gigantic barrages erected on the Jumna, in defiance of general scepticism, now pay nearly seven per cent. return on their capital outlay, while the great reservoir at Assouan and the extension of irrigation canals all over Egypt have fertilized immense tracts of desert.

In an interesting series of articles recently contributed to the Akhbar newspaper, a French agricultural expert describes, for the benefit of his compatriots in Northern Africa, the astonishing progress of irrigation in the American State of Utah which has enabled the inhabitants to reap satisfactory crops under climatic conditions which 


\section{ASPECTS OF ALGERIA}

closely resemble those of Algeria. Not only has this population of about 300,000 souls consecrated large sums to the development of their water supply, but also to experimental farming of every kind. "In every farmhouse," adds this writer, " five or six agricultural journals are to be seen upon the table, and the phrase 'scientific culture' is in every man's mouth. No doubt our Algerian colonist would greet it with derision, but when one sees the results attained in Utah the meaning of the words becomes evident." The suggestion that the colony should install an agent in Western America who would send home regular accounts of experiments and innovations seems an excellent one, especially as the inhabitants of Utah contemplate despatching an envoy to examine on their behalf prevalent conditions in Algeria.

There is another problem which, even more than irrigation, is forcing itself upon the consideration of farmers all the world over, and that is the growing exhaustion of the soil through reckless cultivation. There is little doubt that in Egypt the decrease in the quality of the cotton crop is principally due to the recently acquired habit of planting cotton every second instead of every third year, and to the limited use of chemical manure. And even in Canada, where the marvellous yearly production of wheat goes on 
without any attempt on the part of the farmer either to rest or to renew the soil, the wisest cultivators are beginning to anticipate the time when alternating crops or summer fallows will become inevitable. The invaluable bersim, so rich in azotes, has proved to be an ideal fertilizer in Egypt. But it has unfortunately no counterpart in Algeria, the luzerne which replaces it as a forage plant being distinctly inferior as a soil tonic.

In a conversation I had recently with a Frenchman who has had ten years' experience of farming in the Mitidja, he expressed the opinion that the raising of sheep and cattle was the most remunerative kind of farming in Algeria. So far it is almost entirely in the hands of the native proprietors of the vast herds which form the natural wealth of the country. Some farmers, of whom my friend is one, buy young lambs in considerable quantities from the natives, and fatten them to sell at a good price to Mozabite butchers. As Algeria spends annually some 2,500,000 francs ( $1 \mathrm{1} 00,000)$ on imported mutton, nearly all of which comes into the country from Morocco, there would appear to be a future for this sort of farming. Besides the home market about a million sheep are exported annually to Marseilles and Tunis.

With regard to the question of labour, the 


\section{I76 ASPECTS OF ALGERIA}

presence of a large native population is of inestimable advantage to the French colonist. It provides him with an ample supply at a daily average wage of about Ifc. $50 \mathrm{c}$. to $2 \mathrm{fcs}$, a rate inacceptable to any European. $\mathrm{He}$ is, however, far from acknowledging his debt to the Arab workman, towards whom he frequently displays an animosity" as inexplicable as it is unworthy. I have, during the course of my long sojourn in Algeria, talked with many landowners, both large and small, and with very few exceptions I have found them bitterly antagonistic to the whole native race.

Of the colony in relation to France, of its importance as an outlet for French capital and energy, the rural settler in Algeria has not an idea. He has, as a rule, only one idea beyond the pursuit of his special variety of agriculture, and that is to dispossess the Arab by opposing any legislation which tends to his protection and development. The native labourer has, of course, disqualifications which it would be idle to deny, but they are more than compensated by his cheapness and docility. On large estates where complicated machinery is in use he has to be supplemented by French or Spanish mechanics. But their shorter hours of work and superior wages will always restrict their employment on the farm, though a considerable proportion of the 50,000,000 francs 
annually disbursed for agricultural labour undoubtedly finds its way into European pockets.

Far be it from me to deny the admirable characteristics which distinguish the French colonist, most of all his courage and endurance. His limitations are, broadly speaking, the limitations of the French peasant-proprietor. Of these the most amiable is the Latin passion for uniformity, and the least-that insatiable rapacity which has made France so rich. The desperate efforts made by the Government to bring settlers into the country by giving them large tracts of land and by minimizing the climatic disadvantages which awaited them, are responsible for a good deal of disappointment and occasionally for disaster. Even to-day, when the system of free concessions has been condemned not only by every modern economist, but also by experience, the Administration cannot make up its mind to abandon it entirely in favour of the public or private sales, which attract a better type of emigrant, and which have been successful whenever the expedient has been tried.

In Algeria, where political intrigue plays a far larger part in public life than it does in Europe, a free concession of land is sometimes regarded as a reward for services rendered during electoral campaigns. Certain it is that the senators and deputies who represent the colony are its strongest supporters. In a letter written two years ago, in 
reply to $\mathrm{M}$. Etienne, then député for Oran, the late Governor-General did not conceal his preference for the system of vente à bureau ouvert as a means of attracting a suitable class of settler at less expense to the Administration. He pointed out that, whereas both systems were concurrently employed, the advantage of numbers lay with the former. Over a space of five years 710 groupes agricoles had been established by sales, whereas I,608 free concessions had been bestowed during the same period. Of these 966 were new grants, the others having already changed proprietors several times. In I9IO the community of Berthelot was established, each free concession comprising from 100 to 135 hectares, the land being of moderate quality, suitable for the culture of cereals, vines and fruit trees, and also for the breeding of live-stock. It would seem that $M$. Jonnart's successor does not share his prejudice against this type of colonization; for the official bulletin of June I5, I9I2, contains a programme announcing the creation of new centres on a large scale, and 100,000 hectares (247,000 acres) are soon to be disposed of as gifts to French emigrants all more or less indigent and inexperienced.

Nor should it be supposed that the emigrant is left to do the best he can on the land which has cost him nothing. Even before he takes possession the Government-General has already provided 
the new village with an adequate water-supply, besides building a school, post-office, wash-house, and a dwelling for the future mayor, with roads and necessary communications. All that the embryo colonist is expected to do is to build his house and to put his hand to the plough. Yet as often as not at the expiration of the five years which must elapse before the emigrant become possessed of the title-deeds to his farm, he sells it for what he can and departs. Of course there are exceptions to the general failure of this kind of official enterprise. In certain districts, such as the plateau of Sersous in the province of Constantine and in some portions of the department of Oran, it has been moderately successful. But, contrary to expectation, those settlements situated near the towns or in districts, where native labour is plentiful and cheap, have not flourished so well as the more isolated villages.

Apart from the alternations of drought and deluge, apart from the late frosts, there is the occasional visitation of locusts to add to the preoccupations of the Algerian farmer. These acridians, which are not unknown in South Africa, make their appearance about every fifteen years. They come in such myriads that their passage obscures the light of day, and when they settle to hatch their offspring no living thing survives within the area they cover, sometimes in layers six 
inches deep. A few years ago a terrible invasion of locusts devastated nearly the whole province of Constantine. The authorities are active in aiding the inhabitants to destroy the pests as soon as they appear. This is usually done by scattering sprigs of alfa over the fields where they have alighted and then setting it on fire, but the damage caused by a flight of locusts is incalculable.

If, however, the difficulty of protecting his crops against the variations of temperature and the scourge of locusts were his only care, the Algerian colonist would not be in a worse case than the Canadian or South African farmer, or any who devote their lives to the task of tilling a strange soil. But by far the greatest disadvantage under which Algeria labours is that indefensible form of monopoly which restricts the transport of merchandise sent from the colony to the metropolis to ships flying the French flag. This monopoly was established by a law passed in 1889, which at the same time provided that the crews of the French Shipping Companies navigating in the Mediterranean should be almost entirely composed of French seamen. Thus the colony, the majority of whose exports are destined for France, has become the victim on the one hand of the navigation companies-who immediately combined to keep up freight rates-and the sailors, or inscrits maritimes, on the other. These latter, owing to 


\section{COLONIZATION OF ALGERIA I 8 I}

their privileged position, can paralyse the whole carrying trade by going on strike whenever the slightest resistance is offered to their demands. Nor do they hesitate to exercise this power.

I had ample opportunity of observing, during the spring of I909, the extent to which the interests of Algeria, amounting in figures to a loss of I $5,000,000$ francs $(£ 600,000)$, were sacrificed. For months the export trade of the colony practically ceased to exist. Torpedo boats conveyed the European mail; and occasionally an overcrowded passenger boat, manned by seamen of the French Navy, crossed the Mediterranean. But the produce, both agricultural and commercial, remained on the African shore. Piles of early fruit and vegetables lay rotting for weeks on the quays of Algiers, and in many cases farmers preferred to let their crops remain unreaped on the fields. To the small cultivator such an interruption of normal conditions spells ruin, while it inclines the large investor to send his capital where trade is not at the mercy of political agitation. The strike of I 9 Io lasted only a few weeks, its proximity to the elections having alarmed the Government into dissociating itself from the strikers, but there is no guarantee that next spring will not witness another. Apart from this probability, the exorbitant freights exacted by the French navigation companies, and the inferiority of their ships, con- 


\section{2}

\section{ASPECTS OF ALGERIA}

stitute a grievous handicap to the exporter. At the present moment it costs more to transport a ton of merchandise from Algiers to Marseilles than from Bombay to Liverpool. In spite, however, of the energetic protests made by the late Governor-General, there seems little prospect as yet of the abolition of this iniquitous monopoly. 


\section{CHAPTER $\mathrm{X}$}

ON THE High PLATEAUX

To experience, within the space of a few hours, the inexhaustible variety which distinguishes the scenery of Algeria, one cannot do better than follow the road that leads from the coast to Djelfa. The fragrance of Blidah's orange groves, through which we passed, seemed to add to the freshness of that morning in mid-June, when even the Gorges de la Chiffa successfully opposed its cool emerald to the challenge of the sun. But as the motor flew southward the blue of the sky appeared to lose the languor of the Tell, though nothing yet reminded me that I was in Africa. Medeah's white houses, diagrammatic and very modern, are surrounded by gardens that might be situated in France, and the meadows she overlooks are gay with oleanders and asphodels, which give but a faint tropical suggestion. But after Medeah, and still more after Damiette, something creeps into the landscape which predicts its approaching nudity.

Berrouaghia, the terminus of the railway, lacks shade as well as character, and the outline of the 183 


\section{I84 ASPECTS OF ALGERIA}

hills that face its shy pavilions betrays a certain accentuation. Soon our slackening speed announced the declivity of the Atlas, and, circling the summit of Montgorno, one catches a glimpse of the whole range breaking on the clouds right away to Boghar. We reached the little town of Boghari round the curves of the mountain's southern flank, shorn of the ilexes that companioned our ascent. The blanched walls of the Ksour, crowning the rock above Boghari, glittered like a diadem - the diadem of the Ouled Nails who are almost the sole inhabitants of this fortified village. For centuries they seem to have awaited there, at this portal of the south, the golden and fugitive embraces of them that pass by.

I was due to lunch at the Administration de la Commune Mixte, where $\mathrm{M}$. and Mme. de Montille dispense a hospitality that suggests anything but an outpost of civilization. We were to start on the following day, with the sous-préfet of Medeah, on an official tour through the forest region. That afternoon was spent, however, in search of the mirage, which during periods of intense heat haunts the desert of Bougzoul. This mysterious phenomenon was new to me, and so, for the matter of that, was the arid and terrible steppe which stretches all the way between Boghari and Djelfa. It possesses every attribute which the mind associates with the desert idea, and in com- 


\section{ON THE HIGH PLATEAUX I 85}

parison with its calcined earth, the Sahara is a garden. Long cracks seam its surface, as if some cosmic whirlwind had rent as well as blasted it. No herb or living thing seeks nourishment in this Gehenna, which looks as if it were abandoned even by the souls of the lost.

On that midsummer day the desert of Bougzoul seemed to vibrate under the shock of the sun, which enveloped earth and sky in a fiery incandescence. Here and there stains of leprous green marked the spot where the last drop of spring moisture had been licked up by the solar thirst. Overhead, the sovereign light involved every sense in a gigantic delusion. Strange music filled my ears-the rhythm of the furnace of Bougzoul-which hovered round the molten telegraph wires, and mingled with the strident voices of the locusts, hastening towards the fields of the Tell. Then the lifting of a rosy vapour revealed a lake which seemed to reflect the profile of palm trees and of great ships. At last I saw it-the mirage, the supreme hallucination-born of the heat and the misery of the earth! What a screen for Nature's conjuring is the desert of Bougzoul, well mated to the savage significance of its name. It seemed to rush through my veins-this incendiary air-as our motor stopped before the fondouk, where the Kaid awaited us with coffee, which but served to whet the thirst that parched 
my lips and throat. The white caravanserai glowed like a star fixed in a brazen firmament, and far away in the luminosity of the horizon the opal mountains of Guelt-es-Stel quivered like insubstantial ghosts.

As we tore back to Boghari, Abd-el-Kader's words echoed through my memory. This is the magic atmosphere of the desert-" qui double la vie" - the atmosphere that stimulates to an acuity unknown before all the faculties of perception and sensation. At this temperature heat seems to produce a kind of conscious delirium, which my cork helmet doubtless prevented from becoming unconscious. Oh, the thoughts I thought in the noontide of Bougzoul-mental vibrations that ceased for ever as we re-crossed the bridge of the Cheliff at the entrance to the town! Only the wonder and terror remained, like the images of a dream whose meaning eludes the morning's reality.

The sun was just awaking in the arms of the dawn as our little covered carriage crawled painfully up the mountain whose crest is the fortress of Boghar. Its summit commands not only the whole department of Alger, but the movements of the nomad tribes, most of whom pass thereby as they come up from the Sahara to the coast. The Romans were the first to recognize the importance of this natural key to the heart of Africa, and the military post they founded there was one of the 


\section{ON THE HIGH PLATEAUX I87}

last occupied by the Emir Abd-el-Kader. He only abandoned it when the game was well-nigh lost, and since that time the French have strengthened its defences. The panorama to be seen from its terrace is more impressive than beautiful. One is too high for detail, and on the morning when I looked down upon it the mists of dawn still enshrouded the valleys of the littoral. Southwards, the Sahara rolled away, a golden sea, into diaphanous space.

As we turned our mules westward beyond the turrets of Boghar, I received another of the surprises which, for the traveller, constitute half the charm of Algeria. Suddenly, without warning, we were apparently transported to Scotland. The camel-thorn bushes had given place to a forest of fir trees, not serried and gloomy, but growing out of moss and bushes as they grow round Peebles. For miles we drove through the keen air till, at Seba-Ergoud, we discovered the Kaid of the Ouled-Antar with a concourse of his people. This assembly and the ceremony which followed reminded me of the object of our tour. Speaking through an interpreter, a patriarchal person who shared the box-seat of our carriage, the sous-préfet explained to the natives the necessity of aiding the Administration in the task of protecting the forest. $\mathrm{He}$ gave instructions as to the measures that should be taken to extinguish fires, and enumer- 
ated the penalties which incendiarism would entail upon the tribes. At this stage our cavalcade was joined by a Commissioner attached to the Forest Service. He made clear to me the difficulty experienced in persuading the Arabs that the welfare of the country depends on the preservation of the woods, which are not uninhabited as they are in Europe. From time immemorial they have harboured a large population, who live in little huts or gourbis made out of branches, and whose beasts find pasturage in the undergrowth.

It must be confessed that the problem of protecting the trees, without expropriating those tribes who regard them as their own property, is not easy of solution. In some cases they have been compensated by gifts of land outside the forest radius, in others they have been left within enclosed areas. But though the flocks are obviously no respecters of young shoots, the impression among Algerian colonists that the imaginary change of climate is due to the former destruction of the 'woods by the Arabs is unsupported by history. Poverty compels many of the inhabitants of this region to cling to their ancient grazing rights, and the restriction of this liberty has in many cases resulted in a diminution of the herds. When the sheep and cattle were first deprived not only of their accustomed pasturage, but of the shelter of the trees, thousands succumbed to the 
winter cold of the steppes. The Government is, of course, keenly aware that the preservation of the flocks is at least as important as the preservation of the forests. But, as I said before, the question of saving the first without inflicting injury on the second is fraught with difficulty.

The Kaid and his goum, or detachment of cavaliers, rode with us to Dahlia, where M. Giacobbi repeated his lecture to an attentive audience. At this halt we left the carriage to ride on horseback up the hill, where the pines had given place to the pallid verdure of the cork and evergreen varieties of oak, whose timber forms a considerable item in the list of Algerian exports. Riding through the flowery meshes of this wood, I began to doubt the reality of the desert of Bougzoul. How far we already were from the events of yesterday! The songs of the birds in the honeysuckle, the scent of the crimson luzerne, and the smile of a blue spike that looked like a lupin, all seemed to give them the lie. An hour's climb brought us to the cottage of the Commissioner, where lunch and rest awaited us - a bright little house such as shelters the human intruder in many a similar scene north of the Mediterranean. Africa, its traditions and its features, had disappeared as if by enchantment.

'Towards the close of day, after four hours' drive over a forest track, we descried a company of 
horsemen riding towards us across the meadows which cover the lower levels of the hill. This was our host, the Kaid Abdat-Missoum, with his goum. His red robe of office, and his horse's rich caparison, outshone the dying day and the poppies trampled under the hoofs of his escort. Black spots studded the green of the farthest fields, as if a flight of colossal ravens had poised thereon and been fettered, wings outspread, to the glebe. These were the tents of the Ouled-Hellal, two of which were to be our habitation for the night. As we drew near to the encampment, other horsemen came to greet us, preceded by the Kaid of the Ouled-Aziz, who bears a name well known in Islam. This was the Bey Boumezrag Ali, full of years and decorations, and speaking, alas! a French almost unintelligible even to the practised ears of M. de Montille.

There was revelry that night at Ain-Azem, for a fantasia had been arranged to beguile the hour before dinner. This name indicates an exhibition of Arab horsemanship, the finest in the world, while the performers "make the powder speak," till the air is full of the smell of war. The horses, as excited as their riders, dashed one by one up to the platform where we sat, stopping dead within a sword's length with a suddenness that would have unseated any cavalier but an Arab. Again and again they advanced at full gallop, hoarse cries 


\section{ON THE HIGH PLATEAUX I91}

escaping from the lips of their riders as the smoke from their rifles. And in the whole scene there was I know not what of gallant and ferocious play, of waving colour and mellowing light-a pageant whose theatre was the unknown, untravelled forest glade.

Hospitality is the first of the duties enjoined in the Koran. To him who exercises it Mohammed promises twenty of God's most precious graces. "Be generous," he urges, " towards your guest, for he is at your mercy. When he enters he brings you a benediction, when he leaves you he takes your sins with him." And again: "Generosity is a tree planted in heaven by Allah, Ruler of the world. Its branches touch the earth. He who treats his guests well, who gives them welcome and good cheer, will mount to Paradise by means of those branches, for Allah will never smite the hand that has made gifts." And the Arab has never since hesitated to offer to all who come the hospitality ordained by the Prophet. His riches he will lay at the feet of a stranger; even in his poverty the traveller may share. The welcome of the tent is spontaneously extended to "the guest of Allah" as the accomplishment of a religious duty.

If the guest is a Roumi, whose digestion is not his strongest point, the dhifa, or Arab banquet, may be something of an ordeal. The menu of 
our evening meal, written in Arabic and in French, is now before me as I write this reminiscence of native hospitality. It consists of twelve courses, beginning with a rather pungent soup and followed by mutton cooked in seven different ways. But the pièce de résistance was the mechoui, or lamb roasted whole, which has to be eaten with the fingers. After ejaculating a pious Bismillah!"In the name of God" - each guest in turn tears off the piece which most appeals to him, until nothing is left but the hideous skeleton of the feast. As the lamb is cooked till the flesh' is in rags, the operation of helping oneself presents no particular difficulty. Unfortunately the Arabs have a habit of keeping butter much as we keep wine. They believe its taste improves with age, an opinion which, for European visitors, somewhat impairs the pleasure of the repast.

But in spite of the age of the butter and the novelty of a night in the open air, fatigue prolonged my slumbers till the Kaid's colossal sloughli, in quest, no doubt, of scraps from our table, pushed aside the suspended carpet which formed our tent and let in the limpid light of dawn.

While we were drinking our coffee M. Giacobbi delivered once more his little sermon on the duties of the tribe towards the forest. I had thus an opportunity of observing the sons of the Ouled- 



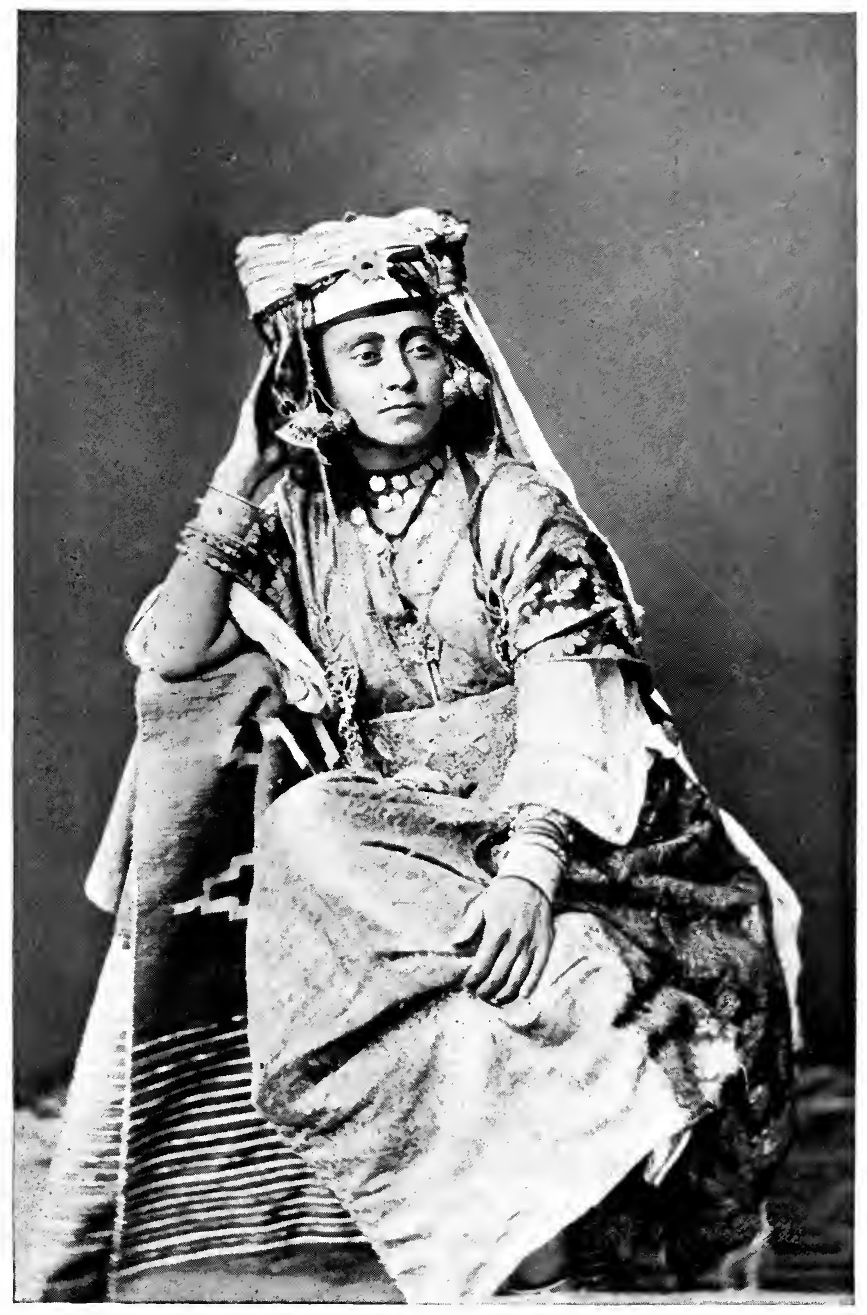

AN OULED-NAIL 
Hellal. Less alert than the nomad of the Sahara, they appeared more sturdy and, at the same time, more docile. With the exception of the Kaids and their goums they were rather a ragged crew. Although rags on an Arab are not invariably an evidence of poverty, these foresters do lack the wealth and also the numbers of the southern tribes. Many of the douars do not reckon more than I,500 to 2,000 souls all told.

Once more behind our valiant mules, we continued our journey to Letourneux, a centre of official colonization which I was anxious to see. This road took us well away from the woods towards the corn-lands of the High Plateaux, and all the morning we drove through acres of cereals, just yellowing to the harvest. I would fain believe, ill disposed as I am towards the principle of free concessions, that all these artificially created villages do not resemble Letourneux. One cannot imagine why it was ever placed there, out of reach of any railway or market. This isolation perhaps accounted for the eagerness of the inhabitants to pour their grievances into official ears. Every one of them had a grievance, not only against the fate that had cast their lot in Letourneux-that would have aroused my sympathy-but against all the neighbours who shared the squalor of its single street. Dissensions of the bitterest kind seemed to form the chief occupation of that little com- 
munity, which seized this occasion to tell the story of its strife. Needless to say, both the sous-préfet and the administrateur did their best to bring peace into the discord of Letourneux. They listened to each one's tale, promising help and redress where it was possible. But the place made a painful impression on us all, and, as an example of State aid to the emigrant, it was lamentable indeed.

Having seen it at its worst, the sight of colonization at its best was a welcome relief. The farm belonging to $M$. Cazelles, where we lunched, shows what capital and industry together can accomplish in Algeria. Around the cheery farmhouse was a village of buildings occupied by the European overseers, and by agricultural machinery of the latest pattern, while as far as the eye could see healthy corn crops awaited the reaper's hour.

The return drive to Dahlia, where we were to sleep that night at the house of the Kaid of the Ouled-Antar, brought us again through the heart of the forest region. A sombre mantle of pines covers many of the heights, but the majority of the trees belong to the oak family. This valuable timber augmented the budget receipts in 1909 by over six million francs. But owing chiefly to the fall in the price of cork this sum was diminished in 1910 to $3,596,440 \mathrm{fcs}$. ( $\mathrm{I}_{443}, 857$ ), inclusive 
of the $638,915 \mathrm{fcs}$. $\left(£ 25,55^{6}\right)$ brought in by the sale of bark and faggots.

Besides these woods of the High Plateaux, the evergreen oaks of Djidjelli contribute to the bulk of this export, and also the splendid cedars which cover a great part of the Aures Mountains. Out of the entire expanse of forest-land in Algeria, nearly $3,000,000$ hectares $(7,500,000$ acres) in all, about two-thirds are the property of the State. During recent years the Service of Woods and Forests has extended its organization. In addition to the construction of roads and maisons forestieres for the accommodation of guardians, a considerable amount of replanting has been done, both in the department of Alger and of Oran. The necessity for our tour became more evident to me when I learnt that cases of injury to the woods, brought into court in 1910, attained the number of 29,707 . Of these, 13,034 came under the head of abuses of the rights of pasture, and here we touch again upon the difficulty of excluding the native population from privileges which they and their ancestors have always enjoyed, and which are essential to the existence of the herds.

In Cape Coast Castle, similar difficulties have attended the application of our Forest Ordinance of I III, and in response to the protests of the Aborigines Protection Society-an organization founded by the Chiefs themselves-Mr. H. Con- 
way Belfield was sent out on a commission of inquiry. From his report just published I cull the following paragraph-

"The suggestion made by the Chiefs that the forests should be left in their own hands, and that government intervention should be confined to teaching them how to manage them, is not a practical proposal worth serious consideration. There is no real desire on the part of the people to conserve the forest land-they are naturally careless and wasteful in their methods of dealing with it, and they are quite unconvinced that any alteration will tend to the advantage of the country. Even, therefore, if it were possible to organize a system of instruction which would instil into the Chiefs a knowledge of the elements of forestry, nothing short of the strictest supervision and direction, amounting in practice to compulsion, would suffice to ensure the effective application of that knowledge by the present generation."

The question of afforestation has only just begun to agitate the official mind in England, where the extent of the State forests is proportionately smaller than in any other European country. As I sat at dinner on the terrace of the Kaid's house at Dahlia, watching the evening fade over the delicate green of the oaks, I thought of the neglected dells of our New Forest, where nothing is done either to increase its value to the State 
or to arrest the natural process of decay. Considering that Great Britain spent in 1909 $£ 23,000,000$ sterling on imported timber, it is no wonder that the problem of afforestation is attracting the attention of the Government. In the report of the recently appointed Royal Commission it was asserted that, without encroaching upon agricultural areas, 900,000 acres of land were available for afforestation in the United Kingdom. Every year the price of timber is rising, as the reserve in Russia and Sweden, the chief wood exporting countries, are beginning to diminish. And although America exports annually $£ 20,000,000$ worth of wood, she spends almost as much on importing the same commodity.

With the exception of India, where the Forest Department is a highly organized and efficient service, we have hitherto done little to prevent the denudation of the wooded reserves in our Crown Colonies. The history of dependencies such as Ceylon, the Straits Settlements and Mauritius, is full of protests and appeals, addressed by successive Governors to the Colonial Office in London, against the persistent sale of forest areas belonging to the State, and the consequent destruction of the trees in the interests of private individuals. In many cases the clearing of timber on a large scale has resulted in flood and fever, and in the impoverishment of the soil through disastrous kinds 
of culture, such as that of the tapioca plant in Malacca. Experience in our tropical colonies, not to mention the inundations in France in I9ro, proves that the sacrifice of forests to agriculture is eventually attended with calamity whose cost to the country far surpasses the advantages supposed to accrue from the spread of cultivation. Trees are the friends of man, and as essential to his wellbeing as any other product of Nature. The influence of the Royal Botanic Gardens at Kew has been eloquently exerted on behalf of this view, but afforestation is a costly branch of public work, and, in spite of the efforts of men like Sir Joseph Hooker, its utility is still insufficiently recognized in Great Britain.

Hitherto, France and Germany are the only nations who have undertaken the conservation and expansion of their forests upon scientific principles. Of what can be done in this direction I caught a glimpse in Algeria, where the presence of the native inhabitants complicates the question. When, however, all the tracts of waste land have been planted with trees, the risk of inundation and drought should be lessened, and the supply of timber at the disposal of the Government-General should be largely increased, without encroaching upon the Arab pasture rights.

In the dawn of the following day we retraced 


\section{ON THE HIGH PLATEAUX 199}

our steps through the pine woods that steal up to the very walls of Boghar. Before descending once more into the oven of Boghari, we stopped to breakfast with the Governor of the Fort. There I experienced again that cordial welcome for which I have to thank all those functionaries in Algeria with whom I, a stranger and, to a certain extent, a critic, came in contact. 


\section{CHAPTER XI}

THE INDUSTRIAL DEVELOPMENT OF ALGERIA

THE pulse of a growing colony, that which indicates more surely than any other sign the state of its general health, is the condition of its commerce. If as it develops its industries develop also, if it begins to pay with its produce for most of the necessities it is obliged to buy from other countries, then it may be said to have attained that point when its future welfare is merely a question of time and favourable legislation. In spite of the fact that the deficit in the Algerian budget still exacts a contribution from the metropolitan treasury, the trade of the colony is increasing by leaps and bounds. The efforts she is now making to use her mineral wealth and to improve her railway system shows that Algeria has reached a turn in the tide of her affairs which should lead her on to an era of prosperity, and justify the sacrifice which the mother-country has made on her behalf.

A gain of $53,383,000$ francs $\left(£_{2}, 135,320\right)$ in the total movement of her commerce is demonstrated by the official returns for I9II. Of this increase only 163,000 francs $(f, 6,520)$ is repre- 


\section{INDUSTRIAL DEVELOPMENT 20I}

sented by exported produce, as against a rise of $53,220,000$ francs $(£ 2,128,800)$ in the value of her imports. But as the total value of the former in I9II is recorded at $513,430,000$ francs $(£ 20,537,200)$, while the latter attained $565,188,000$ francs $(£ 22,607,520)$, it is evident that Algeria has nearly reached the moment when her imports and exports balance each other. As may be imagined, the surplus production of the colony consists chiefly of cereals, wine, olives and vegetables, which with sheep and oxen, including their skins and wool, form the principal articles of exportation. In exchange for these Algeria is a purchaser of all kinds of manufactured articles, besides large quantities of sugar, coffee and spirits. When we reflect that the colony has not yet reached half a century of existence, this approximate equality between the value of exports and imports argues well for its future fortune, although the statistics for I9I I register a relapse from the phenomenal prosperity of I9IO. It must be remembered that as late as 1890 our colonies of Australasia still spent $£ 3,000,000$ sterling on imports, in addition to the $£ 65,000,000$ which their exports brought them, and that when they were nearly a century old.

An analysis of these figures demonstrates that Algeria spent $42,237,000$ francs $(f, 1,689,480)$ more on manufactured goods in I9I I than in 
the previous year. This increased demand is most visible in machines of various kinds, automobiles and leather, besides firearms, gunpowder and ammunition. Vegetable products come next in order of importance, oil and sugar heading a list which includes wood prepared for building purposes and alcohol for burning. First among imported minerals are iron and steel, followed by lead, cement and mineral oils-all showing a considerable rise on the consumption of I9IO. This rise is not, however, characteristic of the trade in animal products, both imports and exports being scarcely superior in quantity to those of r9ro. Turning to the export table, one is immediately struck by a rise of nearly $10,000,000$ francs $(£ 400,000)$ in the bulk of vegetable products sent out of the colony in I9II, wine and corn being the principal items-then cork-oak and alfa. The exportation of manufactured goods increased coincidently three and a half million francs in value, and minerals about half that sum.

Since 189 I an almost absolute reciprocity reigns between the customs tariffs of Algeria and the metropolis. This is modified only by a universal ad valorem tax of fifteen to twenty per cent. imposed on all cargoes entering Algerian ports, and designated the octroi de mer. This imposition is a simple and easily collected source of revenue, most of which is distributed among the various 


\section{INDUSTRIAL DEVELOPMENT 203}

communes of the colony and allocated to works of public utility. This reciprocity and the compulsory transport of all merchandise under the French flag confines the bulk of the Algerian trade to the mother-country, a restriction which has increased as public sentiment in France leans ever more strongly towards Protection. Statistics for I9I0 show an increase of $193,000,000$ francs $(£ 7,720,000)$ in metropolitan imports, and only $24,000,000$ francs $(£ 960,000)$ in goods purchased from foreign countries. This disproportion will probably become more marked as the tendency to exempt French manufactured articles from the octroi de mer becomes more universal in application. On the other side of the medal the same inclination is evident. The exports from Algeria to France increased in 1910 to the extent of I $49,760,000$ francs $(£ 5,990,400)$, while the augmentation in value of those which find their destination in other European ports does not surpass $14,289,000$ francs $(£ 571,560)$. This interchange, it must be remembered, is far more beneficial to France than it is to the colony, where it cannot but have a retarding effect upon its commercial expansion.

Industrially considered, Algeria is still in its infancy. Nature has cruelly deprived it of the element most essential to the establishment of factories, for every ton of coal comes over the sea 
into the colony, most of it from England and Germany. Such being the case, Algeria can never hope to manufacture its own raw material, and its industrial evolution must therefore be limited to a wider exploitation of its natural resources. This can certainly be accomplished in many directions, for as yet its underground wealth is almost untouched. Some deposits of iron, zinc and lead have been developed in an intermittent way, but of the ninety-six concessions granted by the Government-General for the exploitation of mineral rights, only fifty-seven were actually working in rgrr. Of these ten were iron-mines and thirty-five a combination of zinc and lead.

$\checkmark$. There is little doubt, however, that Algeria, and especially the province of Constantine, possesses in the Djebel Ouenza iron deposits of remarkable richness, though as yet she has not, owing to the necessity of referring all demands for railway concessions to the central authority, been permitted to work them. In order to do so it is essential to construct a railway for the purpose of transporting the ore over the two hundred miles between the mine and the nearest port of Bone. To carry out this enterprise an authorization from the Chamber of Deputies is necessary, and in spite of the fact that a hitherto neglected region would be opened thereby, the permission has not yet been granted. The opposition of the Socialists, in the 


\section{INDUSTRIAL DEVELOPMENT 205}

interest of iron operatives in France, was strengthened by a suggestion from the Ministre de la Marine that the Ouenza output might well be diverted to the port of Bizerta in Tunisia, whose activity the Government is for military reasons anxious to entertain. But as M. Jonnart, who laboured until his recent retirement to secure the benefits of this new industry for the colony, once pointed out in the French Parliament, Great Britain has never attempted to add to the strategic importance of Malta or of Gibraltar by creating an artificial movement of commerce in these ports. The susceptibility of France on this point can be gauged by the universally expressed fear that as France produces more iron than she consumes, the only markets for an Algerian output would be English and German. As, however, the Ouenza iron deposit is non-phosphoric, it can only come into competition with similar non-phosphoric products in Spain and Sweden, from which countries the foundries in England and Germany now buy their raw material. Thus the market for French phosphoric iron is really in no way menaced by the opening of the Algerian mines.

It is, therefore, to be hoped that the present Chamber will take a wider view of the Ouenza claims, for the future of Algeria largely depends on the exploitation of her mineral resources. In the opinion of experts these are varied and 
abundant. It is thus not impossible that the presence of iron, zinc and phosphates-of which Tunisia exported 1,293,196 tons in 1910-in payable quantities will do for the colony what the goldfields of the Rand have done for South Africa. In any case the hidden treasure, when brought to light, should console the discouraged agriculturist. But this end can only be secured by giving generous support to the prospector and by the application of an enlightened mining law.

Other kinds of industrial enterprise await the capitalist. Algeria is rich in marbles, yet a few years ago there were only three quarries in the whole colony. In the province of Oran there are mountains of onyx practically undisturbed, and in the plain of the Cheliff oil has recently been discovered, the outer edge; it is thought, of a field which extends eastward along the Mediterranean seaboard. Four companies, one English and three French, for the exploitation of petroliferous concessions are already in existence, and boring operations are being actively carried on with fairly encouraging results.

The exportation of alfa, or esparto grass, a kind of tough and feathery brushwood which covers immense tracts stretching from Morocco to Tripoli, has diminished of late years owing to the excess of supply over demand. The stalk of this grass, after boiling, is pressed into sheets of fibre, 


\section{INDUSTRIAL DEVELOPMENT 207}

and used in the fabrication of the highly glazed paper used for illustrated journals. This glaze is obtained through clay loading, and alfa fibre alone will bear the weight. The bulk of this export goes to England, but as all attempts to cultivate the plant have failed, the supply must ultimately become exhausted. Unfortunately for Algeria this market has suffered from the rivalry of numerous small exporters, who have hitherto refused to combine for the purpose of regulating prices and output.

Some idea of the extent of this trade can be gathered from the report of the British ConsulGeneral for 1910. During that year we paid $£ 42,000$ for alfa, which still heads the list of exports to the United Kingdom, being $£ 23,000$ in advance of 1909. Next to alfa comes iron ore, which we consume to the value of $£ 305,440$, zinc ore representing $£ 64,360$. Of barley 10,472 tons found its way from Algeria to Great Britain, or more than double the amount of the previous year. But although the total amount of exports to our shores increased from $£ 659,000$ in 1909 to $£ 797,000$ in igro, the general tendency is towards diminution. After a steady decline in previous years, the bulk of our imports to Algeria remained stationary in 1910 at a figure of $£ 556,000$ value. Although our agricultural machinery holds its own better than our other exports, it has now 
to contend in this market with the United States, Germany and Roumania. Our trade in cotton and woollen goods, formerly so flourishing with the colony, is to-day almost extinct, killed by the duties imposed in 1892 .

Time was, moreover, when the whole North African trade was carried in British ships, but that time is past, although the docks at Algiers are still managed by an English company. Every year witnesses an increase in the number of vessels touching at Algerian ports that fly German, Dutch and Norwegian flags to the detriment of the Union Jack. Lower wages and smaller crews enable foreign owners to quote easier freight rates, and apart from this consideration, the hide-bound conservatism of British commercial methods is injuring our trade in Algeria as elsewhere. Two years ago an attempt was made to establish a steamship service between Oran and London for the direct transport of fruit and early vegetables. But as the English firms refused to adopt the French plan of permitting shippers to draw against consignments the project fell through. Only I,727 British ships, of just under 4,000,000 tonnage, entered Algerian ports during 1910-a slight decrease when compared with I 909.

The rapid development of all trade, and especially of the mining industry, depends primarily on the efficiency of the means of transport. In 


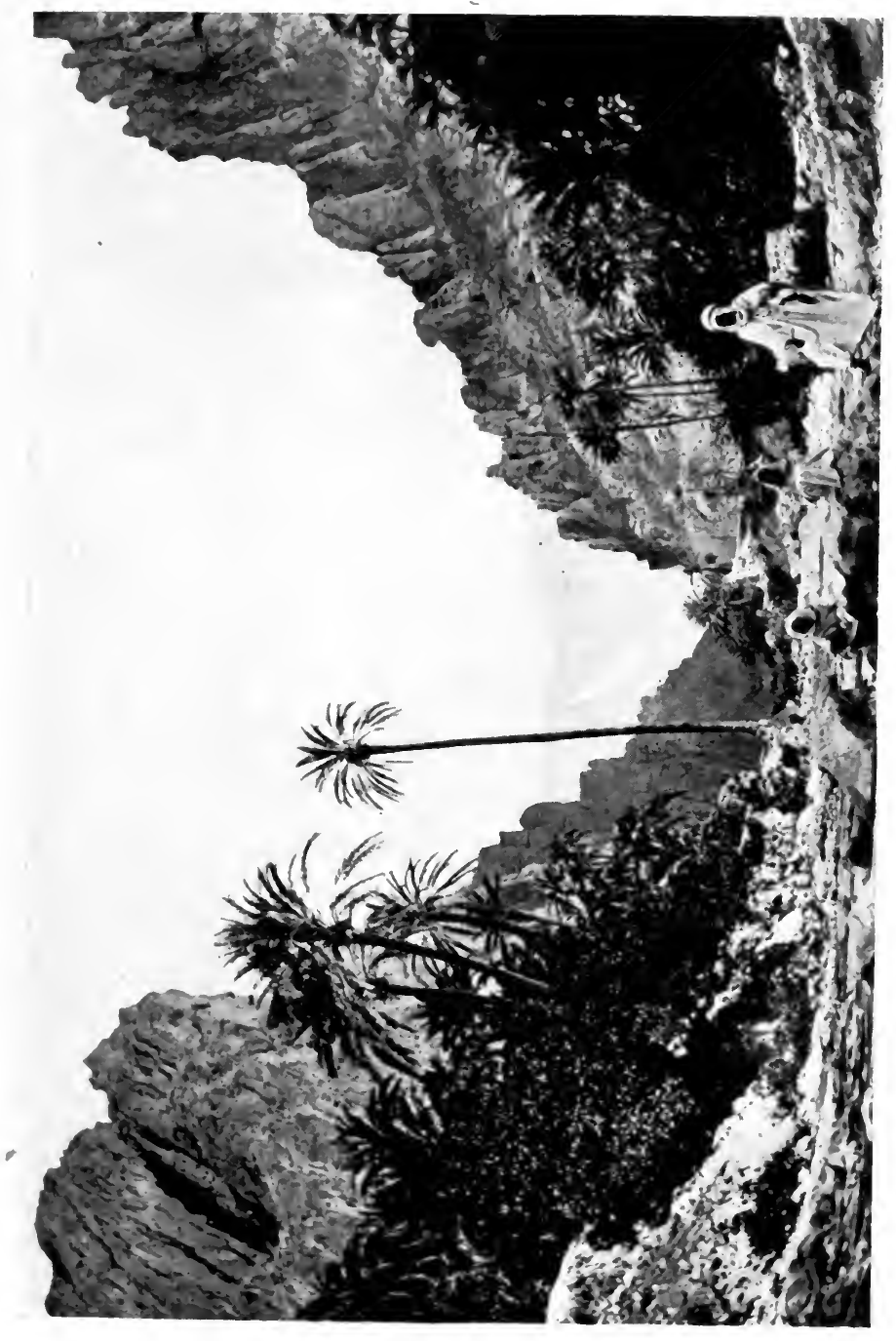

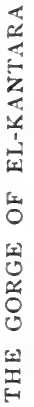





\section{INDUSTRIAL DEVELOPMENT 209}

nothing is the energy of France more remarkable than the splendid network of roads with which the metropolis has endowed Algeria. Broad highways extend in every direction, stretching their inflexible length beyond the barrier of cultivation to lose themselves in the desert sands-such highways as no continental country save France herself, and some parts of Germany, possess. The Algerian railways, though 3,000 kilometres (I 865 miles) in length, are, it must be acknowledged, far inferior to the roads. There are five different companies, none of which seems animated by any public spirit, and until recently, when the efforts of the Government to secure a uniform tariff for the transport of merchandise were crowned with success, their rates were as prohibitive as the service was defective. A credit of $175,000,000$ francs $(£ 7,000,000)$ was voted in 1908 by the French Chamber for the amelioration and ultimate unification of the system. It was further conceded that the indemnity due for the acquisition of the Est-Algerien line should be paid over a period of years out of the State funds.

Besides this improvement in the existing lines, various branches destined to tap districts possessing no actual communication with town or sea are to be constructed in the near future. The first stage of the extension to the south has also been decided on, and in a few years' time tourists at Biskra will be able to explore the Sahara as far as 
Ouargla. Round the project of a trans-Saharian line which would link up into an organic whole all the French spheres of influence in Africa, a vigorous controversy has raged. For the present I will only deal with the commercial aspect of the Grand Central Africain, as the proposed line has been baptized by the most enthusiastic of its advocates, M. Leroy Beaulieu. Quite apart from its strategic value, he believes that within a brief space of time its traffic would pay not only its running expenses, but part of the interest on its capital outlay. The length of the line from Algiers to Zinder, with a branch to Lake Tchad, would not, he asserts, exceed I,920 miles, and need not cost more than $150,000,000$ francs $(£ 6,000,000)$. "As for the traffic," he continues, "once tranquillity is established in the region of Lake Tchad it would certainly become abundant; salt, sugar and divers manufactured products could be transported thither, while on the return journey the trains would be laden with cotton, tobacco, millet, skins of animals and minerals. Lastly, the passenger traffic would not only include traders, colonists, functionaries, soldiers, hunters and tourists of all nations, but the innumerable black races of the Soudan, who, tempted by the prospect of remunerative employment in Algeria and Tunisia, would come to the coast."

Optimism could scarcely go further, and I am 


\section{INDUSTRIAL DEVELOPMENT 2 I 1}

tempted to quote the opinion of another authority on French colonial matters whose pessimism is equally marked. "To the north of the Sahara," I read in Notre CEuvre Coloniale, "we are absorbed in the detestable policy of pushing our occupation farther and farther into the desert. A day may come when the construction of a transSaharian railway will become a useful enterprise, but that day is still very far off. Until it is realized the Sahara can never become a normal avenue of transport, and for the moment France is assailed by more urgent duties than the creation of a line whose object is purely imperial at a cost of 250,000,000 francs ( $£ 10,000,000)$." From the economic point of view I am inclined to think that M. Messimy's is, of the two conflicting opinions, nearest the truth. There is no conceivable reason why the products of Central Africa should seek an outlet towards the Mediterranean, even assuming that the supply largely exceeds the local consumption. Nor is it in any way desirable that the negro population of the interior should be induced to invade the labour market in Algeria, where the competition between the European races and the Arabs is keen enough already. The imperial aspect of the Grand Central Africain is another matter to which I shall allude when I come to consider French colonial policy as a whole.

Meanwhile extensive facilities of transport are 
not the only, or even the first, necessity for the healthy expansion of the colony. Equal in importance is a reasonable and flexible system of credit. Several financial associations, such as the Crédit Foncier d'Algérie, the Compagnie Algérienne, and especially the Crédit Agricole Mutuel, have been founded under government protection with the object of supplementing the usual banking operations, and of assisting the French colonist to develop his land and to await the maturing of his crops. The Crédit Agricole Mutuel, founded in I gor by a special grant from the Treasury, has rendered inestimable service to the small cultivator, its loans reaching in I 909 a sum of over $15,000,000$ francs $(£ 600,000)$. This institution under direct government control suffers somewhat from an excess of red tape. But recent efforts to decentralize its administration and to increase the number of caisses régionales, of which forty-one were in existence in I9IO, should tend to spread the knowledge of the advantages it offers among the rural population.

Although the Crédit Agricole Mutuel offers its facilities to the Arab agriculturist as well as to the colonist, the great majority of its members are Europeans. The necessity of rescuing the Arab from the ubiquitous usurer has, however, been fully realized by the Government-General. Like the Egyptian fellah, the native of Algeria is the 


\section{INDUSTRIAL DEVELOPMENT 2I3}

habitual prey of the money-lender, who is even more venal and voracious here than he is elsewhere. About ten years ago the Sociétés Indigènes de Prévoyance were established with a branch in every commune for the exclusive purpose of lending small sums to natives engaged in agriculture. These societies pay no dividend, and are worked upon a charitable basis, the interest of five per cent. paid by the borrower going to increase the funds available for loans. In 1910, 208 branches were in existence, with a total capital of over twenty-one million francs, and a membership of 540,850 . But despite the rapid growth of this admirable work it is still unfortunately far from having attained its object. Like the Agricultural Bank of Egypt, its success in saving the native population from the vampires which prey upon it has been very limited. It would seem that the fellah is incapable of understanding the difference between fifty or even a hundred per cent. and five or nine. The Arab borrows money where and how he can, returning in the hour of need to his old despoiler the Jew just as the Egyptian returns to the Syrian shark. It is unfortunately impossible to prevent these usurious transactions by direct legislation. Usury is after all as old as Africa itself-a chronic malady which one is sometimes inclined to believe incurable. 
Since the fine Orient-bound steamers of the Norddeutsche Lloyd Line, and also those of the Nederlands Line, have made Algiers a port of call both on the outward and the homeward voyages, the advantages of Algeria as a winter resort have become immensely greater than they were. Although the number of visitors has increased of late years, the administration has hitherto made no effort to assist the capital in becoming, as it easily might, a rival to Cairo and the Riviera. When one considers the prosperity which the yearly influx of tourists has brought to Egypt, the supineness of the municipal authorities of Algiers is the more amazing. In order to attract the class of visitor who pays liberally for his pleasures it is essential to provide first for his accommodation, and then for his amusement. Various projects for the building of a casino have been discussed, but none has yet been evolved sufficiently practical to win the confidence of the financier. It is a pity that the old Summer Palace of the Dey, ideally situated between the town and Mustapha, is not devoted to this purpose. Uninhabitable on account of its inconvenient construction, its perfect Arab architecture and its lovely gardens could be easily converted into a casino similar in character to those of Aix or Ostend.

The construction of one or two first-class hotels in the neighbourhood of Mustapha is also neces- 
sary before Algiers can hope to surpass the charms of the Nile or of the Côte d'Azur. At the present moment there is only one capable of satisfying the requirements of the wealthy tourist, and excellent as the Hôtel St. George is, the accommodation it offers is obviously insufficient. The existence of several modern hotels would not only augment the number of visitors, but would inflate the value of town sites, as shops to cater for a superior clientele would replace the wretched emporiums of the Bab-Azoun. To-day there is not a high-class shop in Algiers, though Tunis, with no winter residents beyond its population of French functionaries, is well provided for in this respect. Algiers has, in fact, everything to gain and nothing to lose by persuading a larger proportion of the travelling public to arrest their steps in her smiling bay. The beauty and variety of the country and the excellent roads make up for the absence of such historic monuments as Egypt possesses.

Of the towns in the interior, Biskra is the only one that has laid itself out to allure the stranger, but it has done this in a way more calculated to destroy its natural charm than to add European convenience to the picturesque peace of the Orient. Its unique attraction is the delightful Jardin I.andon, known to the British public through the pen of that ready writer Mr. Robert Hichens. Biskra will be well advised to retain it intact at 
whatever cost to the municipality, for the day when the garden disappears the tourist will disappear with it. If dry heat is his quest he can find it at Touggourt in the heart of the desert, when in a few years' time the projected railway is built. But if he is only in search of beauty there is no need for him to go beyond El-Kantara, where a small hotel already exists, and where a large one would surely be a successful enterprise. For El-Kantara is the gate that leads from the wintry verdure of the Tell into the parched but radiant summer of the Sahara. A deep ravine cut by Nature through the ruddy wall of the Aures gives the wanderer from the north access to the mystery of the desert, or as much of it as his soul can understand. In all the length and breadth of Africa there is no spot, methinks, as lovely as El-Kantara. I have seen it in all seasons when a howling septentrional blast struck the wayfarer like a blow in the Gorges. I have seen its rocks ablaze in the conflagration of sunset following on a blistering July noon. I have breathed its transparent nights, cool with a breeze that is the moon's handmaiden, that rises and falls at regular intervals like the respiration of the world.

The charm of El-Kantara seems to have led me far from the title of this chapter, yet the distance is much more apparent than real, for the face of Algeria is at least part of her fortune. Why should 
it not aid that section of her commerce which consists in extracting the greatest possible advantage from such things as climate, as the opulence of flowers and foliage, as the light that is on the mountains and the sea. They are none the less beautiful because the spectacle is worth paying the price of a journey across the Mediterranean, and a reasonable hotel bill while you are in the act of admiration. As a modern city Algiers is susceptible of radical improvement. Its houses are hideous without being practical, its streets are squalid without being convenient. Its shore is disfigured by a railway line on one side and by slums on the other. And for all these improvements-if the Algerians are wise-they will make the tourist pay, and pay gladly, too.

Nor is this suggestion really at variance with the theory of the future of Northern Africa recently expounded by the celebrated Italian historian Guglielmo Ferrero. $\mathrm{He}$ warns his compatriots, who are already discounting the resurrection of Tripoli, to beware of "the illusion of ruins." To us the temples which gem the shores of Mauretania have no practical message. They merely prove the essential differences between ancient and modern colonization. If the latter should bequeath to future ages any signs of its activity they will be ruins of factories and remnants of railway lines. "When one tries to 
foretell the fate of a youthful colony," writes M. Ferrero, "one should not only estimate the extent of its territory, the salubrity of its climate, nor the fertility of its soil. One should first inquire what position it will be able to occupy in the commercial relations of the world; what products it will be able to sell which the home markets will gladly absorb. In these considerations lie the whole colonial problem of our time." M. Ferrero attributes the prosperity of Roman Africa as much to the exportation of olive oil as to the exportation of corn, and it was evidently not an Olympic caprice which induced Pallas Athene to take that tree under her protection. Its oil, indispensable then for culinary purposes, was moreover the soap of the period, whose nights it also served to illuminate. However lucrative olive culture may be in the present, it is evident that it cannot occupy the position it did in the domestic economy of an epoch infinitely less luxurious than ours.

We need not, however, conclude that no link exists between the past of Northern Africa and its future. As M. Ferrero points out, the Roman conception of the State and the language of Latin civilization persists and will endure, less changed in sentiment and idea than in material structure. 


\section{CHAPTER XII}

DATE CULTURE IN THE SAHARA

MORE than a thousand years have faded into the limbo of the past since Siki Okba ben Nafa, saint and warrior in the hierarchy of Islam, cursed the wells of the Sahara, with those Berber inhabitants of the desert who offered resistance to the armies of the Prophet. And in that sonorous Arabic which, to the uncomprehending ears of the infidel, seems entirely composed of benedictions, a curse is no mere momentary expression of ill-will. What power there may be in the curse of a slave, such as so frequently alights upon a dog of a tourist, I know not, but certain it is that the curse of a saint is a thing to be avoided. For after the malediction of Sidi Okba ben Nafa the sand of the desert, as if in obedience to his command, began to choke up the wells, despite all the efforts of the $R$ 'tassin, as the ancient caste of well-makers was called. These pits, dug by human hands since the beginning of time, tapped the subterranean water, by means of which the desert was made to blossom and to bear. The trade of the R'tassin 
was a dangerous and a difficult one. Each well cost almost surely the life of a man, who, when the strata of clay that confined the water underground was reached, descended alone to pierce the hard surface, and probably to drown in the surging tide. Before he gave his life, so that the village might live and prosper, the chief of the tribe paid over to his family the Dia, or price of blood. But in order to prevent the supply of water falling off, the well had to be carefully protected against the continually silting sand. Day after day, year after year, the $R$ 'tassin fought against the eternal impulse of the desert to obliterate his work. To preserve the precious stream that fertilized the oasis was never an easy task, but with a curse upon his labours it became impossible. Even after an assassin's knife had surprised the saint in his own holy city of Kairouan, the wells went on dying and the palm groves with them. Not until the conqueror from the North had reached the Sahara, just as Sidi Okba predicted, was the curse turned into a blessing.

When, in 1854 , the Colonel Desvaux marched across the Oued-Rhir to occupy Touggourt, he found many of the once flourishing oases at the point of extinction. In the whole region there were barely 339,000 shrivelling palm trees. On the advice of engineers who accompanied the expedition, Colonel Desvaux decided to revive, by 


\section{DATE CULTURE IN SAHARA 221}

the application of Western science, the wells so essential to the existence of the Saharian tribes. Two years later, under the direction of M. Jus, the first artesian well was sunk in the oasis of Tamerna. The scepticism of the natives made the astonishing success of this initial effort the more gratifying. Four thousand litres of water to the minute flowed out of the "Fountain of Peace," as the amazed and delighted Arabs immediately baptized it. During the years that followed, hundreds of native wells were cleared out and new ones sunk wherever the poverty of the people and the destruction of the palms rendered the need of water the most imperative.

With the object of seeing with my own eyes to what purpose the Gallic cock had scratched in the sand, as Lord Salisbury phrased it when the Convention of 1898 recognized the right of the French to extend their protection to the south of their Algerian colony, I decided to tear myself away from El-Kantara. To those travellers who declare that it is too hot to breathe in the desert during the month of May one may turn a deaf ear. There are certain expansions of the æsthetic faculty which, like certain metals, demand heat, and I defy any one to appreciate the wonder and beauty of the "Garden of Allah" with the thermometer below $100^{\circ}$ in the shade. If you cannot stand, and indeed delight in, that temperature, go anywhere 
else in the world, but do not seek to pass the septentrional margin of Africa. It was just this prospect of breathless summer that allured me. I was suffering quite acutely from that fatigue $d u$ Nord of which Madame de Staël complained. The mere thought of its tyrannical activity and its icy spring chilled my soul, eager to escape from the quotidian commonplace I knew too well. 'The desert, that sacred ark of Dar-el-Islam, began to call me, and Borak, the fabulous winged steed of the Prophet, seemed to await me, foaming, at the threshold of my dreams.

I started from Biskra, forsaken then by the fashionable crowd, in the dawn of a windless May morning. Across the flushed sky stretched the sword of Halley's Comet like a menace in the rosy air, while Venus hung, a great lamp guarding the radiant miracle, which faded slowly as the sun rose behind the trembling palms. It needed all the magic of the dawn and the presence of the comet to reconcile me to the prose of our departure. As time was not unlimited with the French officers who kindly permitted me to accompany their tour of inspection in the Oued-Rhir, it had been decided to cover the distance between Biskra and Touggourt in a light carriage drawn by relays of horses. This was a speedier mode of transit than the camel and camping outfit which the latter would entail over a distance of I 30 miles. Nor were my spirits 
DATE CULTURE IN SAHARA 223

revived by the aspect of the plain we traversed for many hours as the mountains of the Zibans grew fainter in the dazzling sunlight. Miles of rugged ground covered with colourless scrub stretched on either side of the track, ill-deserving the name of road. It strained severely the springs of our carriage, which threatened to overturn at every revolution of the wheels. At Saada we reached the first bordj, or military rest-house, where the Sheikh of the village induced us, by the offer of coffee, to descend and stretch our aching limbs. These shelters are in reality little forts, constructed during the sanguinary struggles which preceded the subjugation of the desert nomads, since when they have been converted into rest-houses for the use of travellers.

About noon we arrived at Chegga, where, in the shelter of the bordj, we ate our frugal lunch, while our men and horses rested in what shade the low building afforded from the meridian sun. Thereafter the landscape began to assume a character more arid, if not more forlorn. For some hours we passed through a sandy region, called Hamada, thickly strewn with splinters of basalt, especially painful to horses and camels, who cut their feet on the black stones. For miles the track ascends, till from the height of Kef-el-Dor, or the " hill of the turning," we looked down on what appeared to be an expanse of water undulating towards cliffs 
which suggested the entrance to a harbour. Yet there was no water, no cliffs, nothing but an empty depression or chott covered with a deposit of salt over which played the mirage, that strange phenomenon which I had seen for the first time at Bougzoul. Water living and liquid, it seemed to us here as to the Arab invaders of the seventh century, who, thinking they had reached the sea, turned back towards the fertile lands of the Tell. The name of the crag, on whose summit there is now a military signalling-tower, bears witness to their deception. This salt lake marks the commencement of the valley, or Oued of the Rhir.

"The Oued-Rhir," writes M. Rolland, one of the first engineers who were instrumental in founding "the colony of the Sahara," "is like a small Egypt with a subterranean Nile." Unlike some other students of African topography, M. Rolland does not believe that the Sahara was ever a branch of the Mediterranean, or the ocean of the Greek Argonauts. His observations point to the conclusion that it was once an inland sea, fed, as the underground rivers still are, by the mountain torrents and melting snows of the Aures, and the various mountain ranges in the North. The Oued-Rhir is, in fact, the deepest depression of that western part of the desert known as the Low Sahara, and is considerably below the level of the sea. This fact and the discovery of molluscs and 


\section{DATE CULTURE IN SAHARA 225}

minute fish, both living and fossilized, in some of the artesian wells, appears, however, to give support to the theory that the Sahara was in prehistoric days an ocean estuary, until the sand of the Tripolitan shore severed it from the Mediterranean, while the fierce African sun hastened the evaporation of its waters.

If this hypothesis, which still lacks scientific confirmation, is ever proved, the chotts or sebkas are the relics of that time. It was only by looking repeatedly over the way we had come that I convinced myself of the hollow pretensions of the Chott Merouane. Hours passed while we drove by the side of its apparently rippling waters, admiring the phantom port which seemed to grace its farther edge. Mirage, all of it-a trick played by Nature on the thirsty wayfarer! A trick so often played that now it delights rather than deceives.

But the pictures that Nature paints on the stupendous canvas of the Sahara are not all mirage. The beauty of the sunset as we drew near to the oasis of Ourir was as real as any pageant of diurnal things. A myriad palm leaves seemed to quiver against the oriflamme of the sky, rose with the memory of gold in it, perchance the amber residue of primordial fires. And water-real water-ran singing in our ears as we entered the cool gloom of the palm groves. If the cedar is the king of 
trees, then surely the palm merits the title of queen, so feminine is its grace, its nervously conscious attitude and silhouette. I had scarcely realized all the repose, the ineffable tranquillity that is expressed in the word "oasis," when our horses, refreshed by the light breeze that followed the sunset, dashed out of the green aisles into the desert again. Once more the flaming of the firmament, glow and afterglow; then night, almost before we gained the next oasis of M'rhaier, where it was ordained that we should sleep-the dreamless sleep of those who had been abroad since dawn and sorely jolted withal over nigh upon sixty miles.

It was blazing day ere we started on the following morning for El-Berd, which singularly belied its name of "The Cold" at the season of our visit. Our road, which was no road, led over undulating sand-hills covered with bushes gay with the tiny but brilliant blossoms of the desert. The new village of Sidi Krelil, recently constructed under French direction outside the palm groves, smiled at us from a short distance, no less picturesque than the unhealthy old village water-logged among the trees and consequently ravaged by malaria. A little farther on, three solitary palms marked a natural spring of fresh water christened by foreign transport agents "Ste. Maria des Tringlots." It was high noon when we arrived at El-Berd, where the engineer of the artesian well 
had prepared an excellent luncheon. This was my first opportunity of examining a scientific sinking operation, undertaken in this instance on behalf of the Sheikh Soltan, who came with a fraction of his sixty-two children and grandchildren to welcome us. The well at a level of eighty-eight metres was giving 700 litres (I 54 gallons) of water to the minute, but a couple of days after our inspection that amount was unexpectedly increased to $\mathrm{I}, 500$ litres (330 gallons).

Some hours later we sat watching the wonder of fading day in the oasis of Ourlhana from the roof of the Kaid's house. Coffee, the like of which is not to be found within the precincts of civilization, completed my beatitude, and loth I was to take my place again behind our weary little horses. But we were due at the neighbouring oasis of Djamma, where the Kaid Si Ahmed ben Lalali had offered us the hospitality of his house. In rather formal but perfect French he placed all he possessed at our disposal-a fine figure of a man, whose gorgeous robes of office I could just discern in the gathering dusk.

Our inspection of the well at Djamma, giving 750 litres ( 165 gallons) to the minute at a depth of fifty-nine metres (sixty-five yards), occupied the early hours of the morrow. It was followed by luncheon at the house of the engineer and some dalliance with the daughter of the Kaid, aged three,

Q 2 
a bewitching person clad in blue and gold brocade. Tearing ourselves away from the seductions of Nouna, we reluctantly continued our journey with jaded horses. For some time our road lay through the palm woods, for Djamma is in the heart of the most important centre of date culture in the OuedRhir. At Moggar, a beautiful but fever-stricken village about to be transplanted, the Sheikh brought us coffee to the carriage, and we left with him one of our little beasts, whose lameness hindered his two companions. No sooner out of the shelter of Moggar than a storm of rain and wind struck us in the face. These sudden squalls, an expression, maybe, of the desert's petulance at the pressure of strange feet, often disconcert the traveller. Even after it passed, the angry sky seemed to impart its menace to the sand-hills, through which our exhausted horses could scarcely be persuaded to drag us. The track, lost in the mist of whirling sand and evening shadow, seemed to double and twist in every direction. Just as we were facing the possibility of a night in the desert, at the mercy of the simoom and the sport of every Djinn in Islam, the lights of Touggourt twinkled at us round the heaving shoulders of the dunes. At the edge of the town we were hailed by a party of horsemen just starting on their way to discover our whereabouts. It was near midnight and as hot as noon. We greeted them like 
DATE CULTURE IN SAHARA 229

brothers, and Touggourt, O jewel of the Sahara! looked to us like home.

All night the south wind wailed through the palms, and we lay gasping and sleepless. Morning light revealed a pall of fine dust overlying every object within the house as without. Sand everywhere, in the food you eat, in the air you breathe, omnipresent, omnipotent. Let none pretend to know the Sahara who has not met the simoom, who has not felt its stifling caresses, and known the fever that it brings with its strange exhilaration and its listless agony. All day long the simoom called, the call of the desert, and at dusk the sun sank into a sea of blood. But the dawn of the following day was calm and fair. The palm garden that surrounds the old palace, now occupied by the Commandant des Territoires Militaires $d u$ Sud, whose guests we were, only rustled a gentle protest under the influence of a light breeze from the north.

The streets of Touggourt are a series of twisted arcades designed to protect the dwellers therein from the wrath of the sun. The houses, even the modern ones, are built of the red, sun-baked earth, for the French have been careful that the improvements inaugurated in the town should not destroy its Arab character. In the midst of the square gushes the largest well in the Oued-Rhir, 182 metres (200 yards) deep, giving 4,000 litres (880 
gallons) each minute. It nourishes 175,000 of the richest date-palms in the Sahara, many of them deglet nour, as the finest variety of dates are called. Under their shadow abundant crops of cereals are grown, as well as fruit trees and vegetables in profusion. While dining that evening at the officers' mess we were interrupted in the consumption of giant asparagus by the arrival of a horseman bearing an invitation from Si Mohammed ben Mohammed el-Aid, Sheikh of the celebrated Order of the Tidjania, to lunch on the following day at the Zaouiya of Tamelhat.

We made an early start on the morrow in a fragile vehicle driven by an old negro much burdened with fat, sent to convey us thither across ten miles of sand-dunes. Our first halt was to be at Temacine, and about a mile before we reached this ancient town, formerly fortified and surrounded by a moat, we were greeted by the Kaid, who had ridden out with his escort of cavaliers to do us the honours of his circonscription. Si Abd-el-Kader ben el-Hadj Said is a descendant of the former kings of Touggourt, and right royal he looked in his scarlet burnous, half-hiding a dolman of purple velvet embroidered with gold. Under his guidance, after the customary coffee, we scaled the minaret of the mosque. Never shall I forget the scene that rewarded our exertions! Beneath our feet lay the flat-roofed, arcaded town, in silvery 


\section{DATE CULTURE IN SAHARA $23 \mathrm{I}$}

silence, circled by its walls; and then, beyond the road which was once a moat, by another rampart of palms and verdure threaded with ribbons of water. And towards the horizon, outside Temacine's double battlement, stretched the desert - the desert where there is nothing but infinite light filling the turquoise spaces betwixt sand and sky. At last I had caught a glimpse of it - the great Sahara of my dreams! Later, on the road to ElOued, I was to stand, but only for an hour, in the saffron shadows of its dunes. Just then I could but gaze upon my promised land, enchained by circumstance like that prophet of old who knew not Allah.

The coincidence of my arrival at Temacine on the day when a Touareg cavalier was starting with the periodical post-bag for Insalah, enabled me to examine the costume which has added so much to the mystery surrounding these intrepid bedouins, who set the French at defiance until about eight years ago, when they finally decided to occupy that chaplet of oases which comprise Gourara, Touat and Tidikelt. Of this Targui'ssingular of Touareg, meaning "raider"-features nothing was visible save the restless eyes, which peered out of the thick folds of black muslin dyed with a preparation of indigo, which enveloped the head and face and served as a protection against the scorching desert sand. Beside the veil he wore, 
over tight black trousers, a loose white shirt, around which a silken scarf, striped rose and gold, was draped like a lady's fichu. A wide belt of leather, beautifully fringed and embroidered, confined it at the waist and matched the sandals, which scarcely covered his feet. Behind this picturesque postman knelt his camel, of the famous racing breed, whose speed is said to outstrip the falcon in his flight. Together they cover in fifteen days or less the distance between Touggourt and Insalah, that strange fortified city whose walls were breached by the Capitaine Pein in I900.

The saddle into which the Targui leapt, bore no resemblance either to the Algerian bassour or to that used by the Egyptian Camel Corps. It appeared to consist of a narrow plank of wood slung just in front of the hump, the rider maintaining his equilibrium by pressing his feet against the neck of the mehara, as these white Touareg camels are called. Prudence prevented me from responding to an invitation to test the docility of the mount; and expressing some scepticism as to the comfort of the saddle, I turned to adjust my camera. When I looked up there was nothing to be seen of the Insalah mail, but a little cloud of dust rising away beyond the palms, and I realized that the post was already on its fleet and noiseless way to the heart of the Sahara.

For the moment Tamelhat was our objective, 
and soon we had abandoned the very uncomfortable equipage of the Sheikh Ettijania for the dim arcades, beautifully carved in places, which led to the Zaouiya itself. Without the noonday sun shone intolerably, but the long corridors that shielded the seclusion of the Marabout were almost cold. Age and excessive adipose tissue prevented Si Mohammed ben Mohammed el-Aid rising from the dirty mattress on which he reclined to express all the joy our visit gave him. This mingled pleasure and regret was interpreted to us by the moqaddem of the Sheikh, a truculent-looking negro, his appointed successor, and probably his son by some Rouara slave. He presided over the steaming couscousou, a kind of semolina cooked with mutton and spice, which formed the prelude to our luncheon. But the menu of the dhifa is classical, only its abundance varies according to the wealth of the host. On this occasion it included such extra dainties as torta, or Arab pastry, and djeraze, or dessert, and terminated, as always, with the mechoui, or lamb roasted whole, which I had already tasted in the tents of the OuledHellal. During the meal, which lasted for hours, I had an interesting conversation with the Kaid of Temacine, who is far superior in intelligence to the majority of Arab chiefs. He had accompanied, some years previously, an expedition organized by M. Bonnelle de Mezieres, which entered Egypt 


\section{4 ASPECTS OF ALGERIA}

by caravan across the Sahara, and had remained long enough on the Nile to compare some points of French and English administration. Although he appreciated the superior tact manifested by the former in dealing with natives, he deplored the unpractical character of the system of education adopted in Algeria. The principle exemplified under our rule in Egypt is to make primary instruction in Arabic obligatory, the secondary education in English, being optional according to the desire and capacity of the pupil. The third division is directed to various technical studies, and, in the opinion of Si Abd-el-Kader, this threefold system is, in practice, the best.

The mocking beauty of a mirage followed us back to Touggourt. Long before the town was visible its luminous reflection greeted our eyes, hovering over the dunes, alluring and mysterious.

To turn my face to the north is always a disagreeable gymnastic, but I have never arrested a southward journey with such reluctance as on the day when we left Touggourt for Sidi Rachid, where a new boring plant had just been installed at the urgent request of the population. With the desire of the virgin desert in my heart, I found little beauty in the sand-hills powdered with low shrubs, many bearing a delicate violet flower called by the natives zeita. That morning, too, was the hottest we experienced, for the sun seemed to burn through 
DATE CULTURE IN SAHARA 235

the thick awning over our carriage, the sides of which scorched unwary fingers. The palm groves which the well at Sidi Rachid is designed to create exist as yet only in anticipation, and in the hut of the engineer it was almost too suffocating to eat the luncheon he had himself prepared for us. A little water had already been struck thirty-eight metres down, so after a cursory glance at the shaft we proceeded on our way to Tamerna, where accommodation had been arranged for us in the house of the Kaid, recently built and furnished more or less in the European style.

Si Abd-el-Aziz ben Masraly, our host for that night, is a gallant soldier who rendered material assistance to the French in subduing the Touaregs, and was present at the capture of Timimoum. He welcomed us with that dignified courtesy of which, more than any other race, the Arab possesses the secret. To avoid the burden of noon we started soon after sunrise the next morning for another of that cluster of palm woods which represent half the wealth of the Oued-Rhir. On the way to Sidi Yahia we made a slight détour to visit the immense well of Sidi Amrane, where the column of water shoots six feet into the air and falls foaming into the innumerable segiuas, or ditches, that carry it to the roots of half a million trees. In this district, especially in the oasis of Ayata, the palms reach twenty feet in height, and testify to the skill and 


\section{ASPECTS OF ALGERIA}

care lavished upon them by the representatives of the Société $d u$ Sud-Algérien, to which this plantation, with its 20,000 trees, belongs. A warm welcome was extended to us at Sidi Yahia by the manager of the society, who with his wife occupies a charming house on the edge of the oasis.

But we were far from expecting the luxury which awaited us. Never, except perhaps in great centres of civilization, have I partaken of such sumptuous repasts as those set before us in this island of verdure situated in the Saharian waste. Under the vivifying influence of the wells the desert seems to attain a degree of fertility never reached under normal conditions in Europe. The fruit and vegetables which are cultivated either under the palms or during the eight years of their immaturity, grow with a luxuriance unknown in the North. In like manner the fowls and turkeys bred thereon would be worth their weight in gold in London or Paris. All the products of the oasis, cooked with a science for which the French are celebrated, had been assembled for our entertainment, and nothing could exceed the simple kindness with which this unexpected good cheer was offered. No more ample demonstration could be imagined of the absurdity of the accusation that the French are lacking in the idea of comfort! Much travelling through unfrequented parts of the world has 


\section{DATE CULTURE IN SAHARA 237}

convinced me that in many respects the French have a far sounder idea of comfort than the English. Nowhere, however, do they seem to have utilized local conditions to such amazing advantage as in that synonym for barren void-the Sahara.

There exist two French companies who undertake, on a large scale, the exploitation of the datepalm in this region. The earliest, the Compagnie de l'Oued-Rhir, possesses large plantations in Touggourt and Ourlhana, while the property of the Société Agricole du Sud-Algérien is concentrated near the little town of Djamma, and consists of about 55,000 trees. In the morning, as we walked in the palm groves, M. Cornu explained to me something of the manner in which the date is cultivated. The actual cultivator, frequently also a proprietor, is the khammes, or native farmer, who shares with the owner of the plantation the produce of his toil. The terms of contract usually give the khammes one-fifth of the date harvest and one-third of all the under-culture, whether it be cereals, fruit or vegetables. With regard to the palm tree, its prosperity depends chiefly upon a combination of moisture with a high temperature, which the Arabs sum up in declaring that it only flourishes when "its feet are in water and its head in fire." Given these essentials, those delicate feathery fronds will stand anything, even the frosty nights, fairly frequent in winter. The 
second condition is supplied by the desert sun, while the first has now been provided by the five hundred wells sunk by French enterprise.

The cost of these operations has hitherto been borne in most cases by the Government-General of Algeria, the funds being allocated in the special budget of the Territoires Militaires $d u$ Sud, which, like the rest of the Colony, enjoys a subvention from the Metropolitan Treasury. On some occasions the commune has contributed a portion of the expense when a well is sunk for its exclusive benefit. Private individuals, such as the Société $d u$ Sud-Algérien, or the Sheikh of El Berd, can also employ and pay the Government engineers to bore for water on their property. Some idea of the extent to which these wells have increased the prosperity of the Oued-Rhir can be gleaned from official statistics.

In the year I 909 the total number of palm trees in this valley alone was estimated at $1,085,000$, or one-half of the number in the whole Territoires $d u$ Sud. As the date is to the Arab what rice is to the Indian, the bulk of the production is naturally consumed within the limits of Algeria and Tunisia. But the exportation of the finest quality of deglet nour is increasing, and reached last year an approximate value of over twelve million francs. A large proportion of this sum directly benefits the Arab population, who own nearly the whole area of the 


\section{DATE CULTURE IN SAHARA 239}

oases. Apart from this fact, native labour is exclusively employed for the well-sinking operations, under the direction of French engineers, who pay out annually in wages a sum exceeding 50,000 francs $(£ 2,000)$. The inhabitants of the OuedRhir belong to the tribe of the Rouara, and are without doubt descendants of the aboriginal Berbers, with a considerable admixture of negro blood, very visible in their black skins and woolly hair. They are a laborious, peace-loving people, living on excellent terms with their French masters, who, besides bringing the precious gift of water to the desert, have rescued them from the predatory incursions of the nomads, by whom they were formerly often despoiled and enslaved.

A long but pleasant drive brought us to the oasis of Ourir, where we were bidden to spend our last night in the Sahara at the house of Monsieur et Madame Bonhoure, relatives of our lavish hosts at Sidi Yahia, and, like them, representatives of the Société $d u$ Sud-Algérien, who own almost the whole oasis. Again we experienced the same open-handed hospitality, and my regret at leaving the last lovely palm grove behind us was increased by the sudden fall in temperature. We left Ourir in the teeth of a biting blast from the north, and I sat shivering in our little carriage till the sun gained power with the approach of midday. The North-we already felt its icy hand at our throats! 
No mirage lent enchantment to the desolation of the Chott Merouane, where we began to retrace our steps, until we turned westward to visit Sidi Okba, a large oasis several miles to the south of Biskra. Here unexpected difficulties have been encountered by the modern water-seekers. The immense boring installation at Sidi Okba has already cost the Government nearly 2,000,000 francs ( $£ 80,000)$, and at 450 metres (495 yards) only a meagre stream of water has been tapped. Unless the subterranean flood can be induced to give up its treasure the oasis of Sidi Okba is doomed. Can it be that some lingering remnant of the curse lurks round the name of the saint, malefic still after fifteen centuries have come and gone?

When I put that question a few days later to the Capitaine Mohammed ben Driss, sometime Agha of Touggourt, his old wolfish eyes seemed to lose their sardonic smile. Superstition dies hard even in an Arab who, as a naturalized French subject, fought the Germans at Sedan, and was once the favourite aide-de-camp of the General de Gallifet. We sat talking in the garden of his villa by the gorge of El-Kantara, talking of the desert and of the insurrection of $187 \mathrm{I}$, when by marvellous strategy Ben Driss captured the rebel Bou Choucha and so brought peace to the Sahara. Some say the French authorities behaved scurvily to the young 


\section{DATE CULTURE IN SAHARA 24I}

lieutenant of Spahis who delivered the South from its worst enemy since the days of the Emir Abd-elKader. Others whisper that the Aghalik of Touggourt-for at all events Ben Driss got that in reward of his services-was no empty honour, but full-too full-of gifts wrung from recalcitrant tribesmen in the good old way. Be that as it may, the villa, which is about all that war and guile have left him, is unpretentious. Nor should it be forgotten, to his credit, that Ben Driss was among the earliest to foresee all that water might mean to the Oued-Rhir. The first palm grove created by modern science was his. For aught I could discover to the contrary, he owns nothing now but the few trees that grace his garden, and the buxom but comely lady, still relatively youthful and much dressed, who bears his name-a name which, once upon a time, spread terror in the South.

But my question, though I repeated it later in our conversation, remained unanswered; and as I walked back to the hotel through the outrageous sunshine, I felt that in the desert a man might come to believe-or disbelieve-almost anything. 


\section{CHAPTER XIII}

\section{THE EVOLUTION OF THE ALGERIANS}

However alluring the natural aspect of a country may be, however interesting its treasures of history or of art, the character of its present population possesses for the student a still deeper import and significance. No analysis of Algerian conditions would be worth reading that did not deal, however superficially, with the Algerians themselves. The elements of which this society is composed have not coalesced for more than forty years, and in the evolution of a race forty years is as one day. But if nothing conclusive can yet be deduced regarding the Algerians, the census of 1906 and that of I9I I do furnish details from which inferences concerning their probable line of development may be drawn. These details are not as ample as they might be; indeed the statistics relating to the European population are the despair of the sociologist. When not obviously erroneous, they are incomplete, and every year a different principle seems to guide their compilers. But in spite of these deficiences the task of disentangling what- 


\section{EVOLUTION OF THE ALGERIANS 243}

ever truth they may contain has tempted several historians of contemporary life. Of their criticisms the most important are Dr. Ricoux's Démographie figurée and the colossal work of Professor V. Demontes. The former was published fifteen years ago, and time has invalidated many of its predictions. It is, therefore, to Le Peuplement Algérien that I am indebted for much of the information upon which the opinions expressed in this chapter are based.

In describing the modern Algerians as a Mediterranean race the use of that adjective is justified as much by geographical as by psychological observation. The purely French element in the colony was, with the exception of the Alsacians-transplanted after the war of 1870 -almost exclusively recruited from the Mediterranean provinces. The pamphlet containing the Government's offer of free concessions was circulated all over France, but it entirely failed to attract either the Breton fishermen or the Norman farmers. The Eastern Pyrenees, Drôme, and the Lower Alpine departments with Provence, were those that responded to the appeal from the African coast, which could, moreover, be reached with comparative ease from the meridional ports. The visitation of the phylloxera was directly responsible for the subsequent exodus from the vineyards of Hérault, Gard, Aude and the Bouches-du-Rhine into the Tell, where a 


\section{ASPECTS OF ALGERIA}

similar soil and immunity from the pest seemed to promise salvation to the ruined viticulturist.

Turning to the Spanish emigrants, the law of I 893 which exacted a declaration of domicile enables us to determine with tolerable certainty the origin of this section of the Algerian population. Although Alicante and Valencia contributed the majority of them during the eleven years which ended in 1905, almost all the Spanish provinces on the Mediterranean seaboard have sent some of their sons across its waters. More complete information exists with regard to the Italians, and the records of their government also confirm the Mediterranean source of their emigrants to Algeria. By far the largest group are composed of fishermen from Campagna and Calabria, though the coasts of Tuscany and even of Piedmont furnished contingents from time to time. The Sicilians show of late years a preference for settling in Tunisia, but there is little doubt that many of the growers of early vegetables who still invade the Tell come from that adjacent island.

We are therefore justified in asserting that the Algerians are a people who have merely transferred their activity from the northern to the southern coast of the Mediterranean. Nor is there anything abnormal about this change of residence. Accessibility is perhaps the strongest factor in colonization, and next to that comes similarity of 


\section{EVOLUTION OF THE ALGERIANS 245}

climate with better opportunities of employment. These conditions also apply to the Maltese emigrants, who formerly came in considerable numbers into Algeria. But since the enormous influx of Spaniards and Italians their influence on the future population has been reduced to a minimum.

The census of I 906 was to some extent a revelation. With the exception of the inclusion of the army in the general statistics, they were better compiled than ever before and the figures are more reliable. The cardinal fact which it demonstrates, and which has been confirmed by the census of I II I, is the growing numerical superiority of the other Latin races over the French inhabitants of Algeria. When one comes to analyse this increase it is evident that in the province of Oran the Spanish colonists are already fifty per cent. more numerous than their Gallic neighbours, while in the province of Constantine the Italians, though not yet predominant, are steadily increasing. All deductions made, the bulk of the European population may be taken at 752,043 , which represents an augmentation of only 127,043 since r 906 . Of this total 304,592 inhabitants are described as of French origin, while the naturalized French amount to 188,068 , and the non-naturalized Europeans to 189,112 . Thus it will be seen that the purely Gallic element-which is, moreover, 


\section{ASPECTS OF ALGERIA}

not quite pure-is already surpassed by 73,588 souls, some legally citizens of France, but all foreigners in blood, habits and language.

If we exclude the very feeble contingent of German, English, American and other strangers it is out of this Latin Mediterranean mass that the future population of Algeria will be evolved. Their interpenetration is immensely aided by the initial fact of their common Latinity, and, in a lesser degree, by their common religion. Both these characteristics are absent from the essentially heterogeneous Irish, German and Scandinavian population of America that is, however, so quickly assimilated. In Algeria the work of assimilation has already begun, a work whose fourfold processes lead towards a unique end. Of these the first and by far the most important is ethnological, for the modification of a race almost invariably begins by the adulteration of its blood through intermarriage.

In the colony the average rate of marriage is about seventy per thousand inhabitants, a figure slightly inferior to that of France and Italy, but superior to that of Spain. Of this estimate about twenty-one per cent. are mixed marriages, which contrasts favourably with the American rate of I9.6. We further learn from the statistics that the French, who are more addicted to marriage than any other people, show no disinclination to take Spanish or Italian brides in Algeria. As 


\section{EVOLUTION OF THE ALGERIANS 247}

women predominate in the Spanish colony their tendency to marry Frenchmen is not surprising. French women and Spanish men are, on the other hand, much less disposed to marry out of their own nationality. Whereas Italians, when they do not choose a woman of their own people, seem to prefer a Spanish to a French partner for life.

Nor do they show any marked disposition to curtail the life contract. The vast majority of divorces take place among the French inhabitants. This is in a measure due to the non-existence of divorce in Spain and Italy, and in 1904 the average rate of divorce was only forty-one in a thousand. As in all colonies the marrying age in Algeria is earlier for women and somewhat later for men than in the metropolis.

If it be true that the most significant fact in the life of a nation is its succession of births, how much more true is it in the case of a youthful colony. The unsettled condition of Algeria in the early days produced a disproportion between the birth and the death rates which should rather be attributed to excessive mortality than to general infecundity. The colonist had not only to fight against the Arab, but against the malaria, which decimated those who attempted to drain the plains of the Cheliff and the Mitidja, and outbreaks of cholera and typhus aggravated these afflictions. The emigration of a number of adult males into 
the country raised the birth rate to forty-one per thousand between 1850 and 1873 . This average was not, however, maintained, for it descended to thirty-three from 1886 to I896, and then to twenty-nine during the period that terminated in I 904, rising however to thirty-one between 1906 and IgIr. This figure is midway between the high rate of Spain and Italy-thirty-four and thirty-five respectively over the same period-and the very low French rate of twenty-one. As might be expected, the Algerian birth rate is higher in the rural districts than in the towns, and highest of all in the Department of Oran, where the Spanish element predominates.

On this latter point Professor Demontes expresses himself with no uncertain sound. "Whether or no," he writes, "the women of the other Latin races are larger in numbers than the French women, their superiority from the point of view of maternity is incontestable, and their descendants will form in the future the majority of the Algerian race. This is the fact, the truth, which it is useless to dissimulate, for it is every day more true. In the near future two-thirds of the children born in Algeria will spring from foreign mothers, or, rather, from mothers of foreign origin." From a study of the relative fecundity of the different races who are in process of adaptation to the conditions of life in Africa, 
one fact stands out conclusively, and that is the very slight influence which the climate has had upon the birth rate. Those people who are prolific in their native country retain this characteristic, and the contrary is also the case.

As I have already stated, the mortality of the European population altogether was so high until about 1876 that the possibility of Algeria as a habitation for white men was seriously contested by sociologists. After that date, however, more or less normal conditions were established, and the death rate sank rapidly to twenty-eight per thousand. The years from 1876 to 1890 were also marked by active immigration from Spain, and the turning of virgin soil which the execution of public works necessitated claimed its inevitable toll of victims; I896, however; saw the death rate as low as twenty, and except in 1904, when another outbreak of malaria occurred, it has never since risen above that figure. For the period covered by the last census it was under nineteen. The statistics on this subject present certain characteristics which Algeria seems to share with most European countries, such as the superior mortality among infants of the male sex. But here, unfortunately, this disastrous superiority appears to survive the age of infancy, and it is impossible to escape the conclusion that the masculine section of the population does not possess the qualities of 
resistance which the feminine section seems to have acquired.

The census of 1906 announces that although more men than women are born in Algeria, it is the women who live longest. Nor is this all. Let us examine the average age at which the greatest number of male deaths occur, and we shall find that it is neither in infancy nor in "the sere and yellow leaf." A diagram which Professor Demontes has prepared embodying the records of 1906 shows that the epoch of highest mortality is precisely when the lowest is naturally expected-that is, between the ages of twenty and fifty. In his prime the normal man ought to possess the greatest capacity of resistance. When it is otherwise, as it is in Algeria, the reason is not far to seek. Alcoholism is the most inveterate enemy of the adult man everywhere, and its ravages are all the more deadly in the semi-tropical atmosphere of the Tell. The abuse of alcohol certainly constitutes the chief impediment to the healthy development of the Latin races established there.

The low mortality in the Italian colony, as compared with their French and Spanish neighbours, is partially due to the fact that the province of Constantine, where the majority of Italians are concentrated, is much healthier than either those of Alger or Oran. The dry heat of the High 


\section{EVOLUTION OF THE ALGERIANS 251}

Plateaux is far less injurious than a lower temperature at sea-level. It may also be that less intemperance reigns among these fisherfolk and gardeners, for their trades are on the whole more dangerous than the occupations of either the French or the Spanish colonists. Certain it is that their resistance is greater. To quote Professor Demontes on this point: "The future of the European races in Africa," he declares, "and that of the French race in particular, depends on their greater or less sobriety in the consumption of alcoholic beverages." When he arrives in the colony, the Spanish pataouette, as the freshman is called, does not drink any more than the Calabrian fisherman, but the former is certainly more apt to acquire the fatal habit. Since 1860 , with the exception of the disastrous 1868 , births have as a whole been in excess of deaths, but the superiority is slight and, as far as the Gallic population is concerned, it is diminishing. Not only are they less adaptable to the climate, but less prolific as well.

Another aspect of this gradual fusion of the Latin races is exemplified by the connection between economic conditions and population. There is a theory, identified with the name of the famous statistician Dr. Bertillon, that a diminishing birth rate is a natural consequence of democracy. The peasant whose exertions have lifted him out of his class is pursued by the constant fear that his chil- 
dren, if too numerous, will sink to his own former level. His family is therefore strictly proportionate to his means, and this sentiment, so characteristic of the French, may have contributed to lessen the number of their children in Algeria. It is unknown, however, among the Spanish and Italian gardeners, who regard a numerous progeny as an advantage which enables the parent to dispense with hired labour. They have, as I pointed out in a previous chapter, almost monopolized this remunerative kind of intensive culture.

Generally speaking, the various races specialize in different directions in the universal effort of bringing prosperity to the colony. For example, the vineyards of the Tell are almost exclusively in French hands. They alone possessed the capital necessary to plant the vines, for with very rare exceptions, the Spanish and Italian emigrants came devoid of all resources. But the millions that were sunk in this enterprise turned out a risky investment, and seemed at one time likely to compromise the future of the French settler. One factor alone saved him from ruin when the price of Algerian wine fell to zero, a factor which will, as long as it exists, preserve his economic ascendency over his rivals. In spite of the periodical falls in the price of wine, in spite of the frequent failure of the corn crop, he has retained possession of the land. Originally in the 
majority of cases it was given to him gratuitously, and although those who accepted free concessions frequently did so with the intention of passing them on, the grant was generally consigned to a compatriot. To-day seventy-three per cent. of the landed proprietors in Algeria are still French, and the remaining twenty-seven per cent. are almost equally divided between Spaniards and naturalized foreigners, two per cent. only being of Italian birth. As long as the soil is his the French colonist need not fear that his numerical weakness will end in his being supplanted in the country which has cost France so much blood and treasure.

Yet that soil is, practically speaking, fructified by foreign or, more generally, by native labour. Besides the vast army of Arab tillers, almost the whole European population engaged in the pursuit of agriculture is composed of foreign workmen. Great numbers of these were, however, made technically French citizens by the law of automatic naturalization passed in 1889 .

This brings me to the third engine of interpenetration, whose object is to confer identical political privileges and duties upon all the Algerian races. By the operation of this law children of foreign parents born in Algeria become French unless, at the age of twenty-one, they elect to retain the nationality of their fathers. It differs from the provisions of the Senatus-Consult in that 
it bestows the gift of French nationality without the previous request of the individual. Its immediate result was to nearly double the legally French population, and to add considerably to the number of youths available for military training. Among those who consider its enactment premature, and even dangerous, is the author of Le Peuplement Algérien. Its pages contain the following sentence under the title of "Le péril étranger.": "The problem as to whether the law of 1889 should be maintained in operation or suspended will become more acute as time goes on. If it is not solved during the next few years the Algerian electorate will, by 1915 or 1920, be chiefly composed of those pseudo-Frenchmen, or Algerians, as they significantly call themselves."

"But has this law had the effect of breaking the moral tie which attaches these naturalized citizens to the mass of their compatriots who have not changed their flag? Evidently not. Political assimilation," he continues, "by which I mean that complete absorption which deserves not only civilian, but political rights, should never have preceded moral and social assimilation. The former should indeed be the natural consequence and sanction of the latter. It can never hasten that desired end in a country like Algeria."

The wholesale fabrication of French citizens has created misgivings in many other minds. A 


\section{EVOLUTION OF THE ALGERIANS 255}

recent Governor-General of Algeria, M. Laferriere, urged some years ago upon the Chamber of Deputies the limitation of the franchise to those foreigners who could read and write the French tongue. The best that can be said for this measure is that it has at least delivered Algeria from those reclamations by foreign powers on behalf of their subjects which, under the name of "Capitulations," has proved such a curse to the British Administration in Egypt. But this benefit is not of itself sufficient to justify the inclusion in the Algerian electorate of illiterate Spaniards and Italians who have expressed no desire for the advantages conferred upon them, and who may eventually make use of that weapon against the interests of the country which forced it into their hands.

For this "moral and social assimilation," which is the ideal of Professor Demontes, represents the final stage in the fusion of the Latin races in Algeria. It is ultimate because its progress is so slow and to a great extent invisible. The only instrument which can assist its accomplishment, besides the flux of years, is the instrument of education. Upon this agent of interpenetration the French Government largely depend, and they have shown such eagerness to welcome the offspring of foreign parents in their schools as to arouse the jealousy of their compatriots. The 
instruction, which is gratuitous, is, of course, given in French, and these foreigners seem equally eager to avail themselves of this opportunity of bestowing on their families the education which circumstances denied to themselves. The youth of the three races is, therefore, mingling in the common pursuit of knowledge, and the influence of this association cannot fail to unify their mental habits and ideas. Gradually the naturalized Spaniard and Italian will lose their actual sentimental attachment to the countries they have abandoned.

To-day this belated patriotism has only been rendered more ardent by a few years of absence. Both have forgotten the hunger and misgovernment which drove them across the Mediterranean Sea, but here the resemblance between Spanish and Italian patriotism ends. The former still adores the golden legend of the past, for the native land he remembers is the Spain of yesterday, not of to-day. The glorious conquests of the Middle Ages fire his imagination and obliterate the memory of Spain's present degeneration. The Italian is, on the contrary, inspired by the splendid future which he believes is awaiting the country where he was born. No more than the Spaniard does he love the Italy of the present hour, but neither exile nor naturalization has so far destroyed his devotion to the Italy of to-morrow. Time and environment will doubtless slowly 



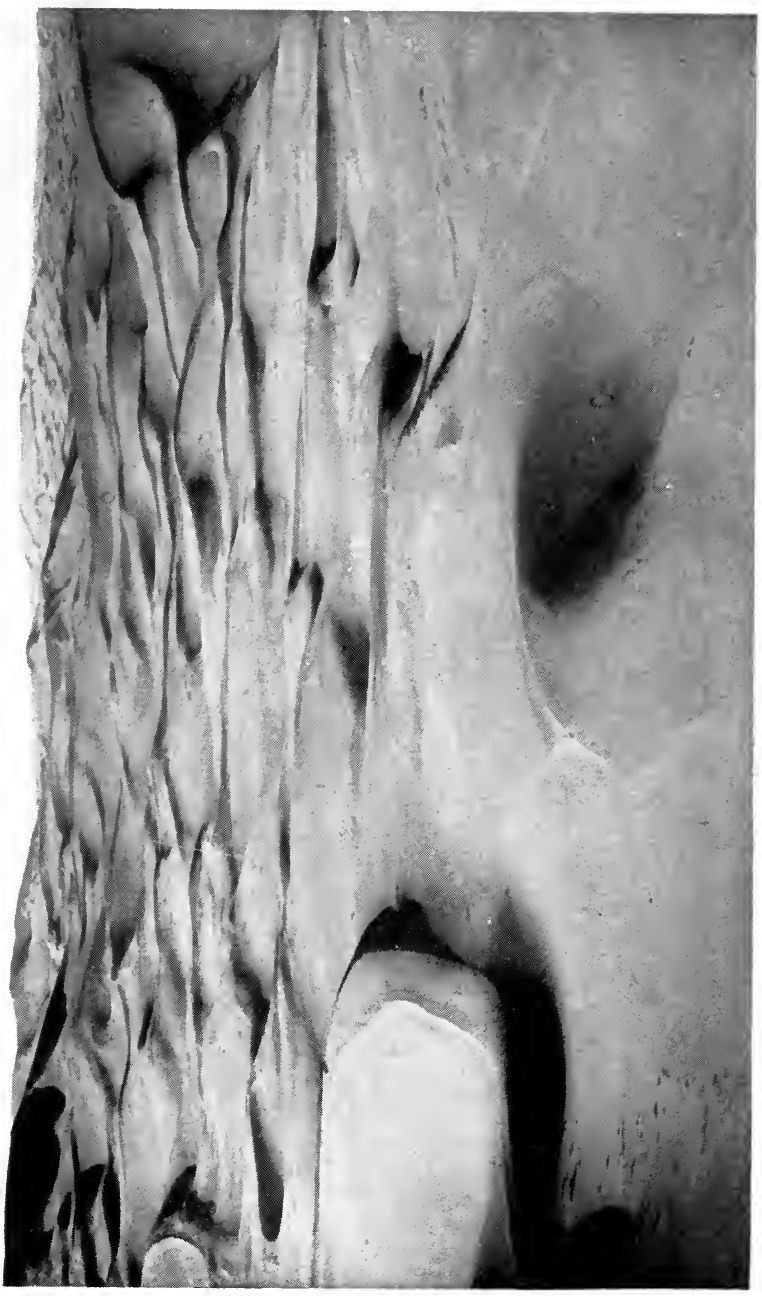

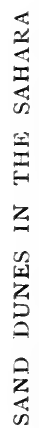




\section{EVOLUTION OF THE ALGERIANS 257}

transfer both these lingering patriotisms to the African shore, for all three Latin races are unconsciously contributing to the production of a fourth, wherein, let us hope, the best qualities of all will find expression.

It is a common axiom among sociologists that nations, when brought into contact, begin by exchanging their vices, for the frailties of humanity are obviously more contagious than its virtues. This is certainly the case in Algeria, where the statistics of crime form discouraging reading. But on this subject it must not be forgotten that the majority of delinquents are not born in the colony, and that a country in the making invariably attracts a large proportion of the wandering criminal class.

In the evolution of the Algerian race the influence of the Catholic Church has been more negative than one might have expected. The application of the Law of Separation to Algeria was, in the opinion of many friends of the colony, a mistake. One of its effects should, however, have been to stimulate the fervour of the Faithful, but the ardour which distinguished the African converts of the primitive Communion seems to have died out of that continent for ever. There is no reason to believe that Gallic scepticism has had any influence on the religious sentiments of their Spanish or Italian neighbours. But these senti- 
ments seem, in the majority of cases, to be limited to a taste for elaborate ceremonial and a passion for the miraculous-limitations which are, after all, universal among the ignorant peasants of rural Spain and Italy. In its truceless war with Islam the Catholic Church, bereft of the infectious energy of Cardinal Lavigerie, has rather lost than gained ground. Its most assiduous missionaries scarcely mask their pessimism, and are apt to quote in its extenuation a phrase of their great chief: "Only through the Africans can we ever hope to convert Africa."

These combined influences making for assimilation have so far acted more quickly upon the Italian colonists than upon the Spaniards, who form $a$ group more compact and more isolated. In the towns where they settle they concentrate in particular quarters, and even in the agricultural districts their farms cluster into veritable settlements. Many parts of the province of Oran have the aspect of Spain. The traveller therein is conscious of a strong individuality, instinctively uniting for the defence of its national attributes. There is little other evidence of this latent feeling, obscurely fighting its losing battle with the pervading influence of the earth-the irresistible earth of Africa. A French writer, M. Louis Bertrand, who is responsible for a series of brilliant novels dealing with the new race, declares that nowhere is man 


\section{EVOLUTION OF THE ALGERIANS 259}

so susceptible to the contact of soil and atmosphere. Verily Algeria is a country of violent contrasts. What could be more opposed to the voluptuous margin of the Tell than the blighted steppes of the High Plateaux, or the diluvian rain followed by parching drought. Think of the alternations of mountain snow and torrid sand, co-existing within a few miles, and you will realize that these strange oppositions must enter into the souls which are subject to them.

Man does not dominate Nature in Algeria as in the north of Europe; more often he is the victim of her caprices, and then he begins to understand, if not to imitate, the fatalism of the Arab. Is this, I have sometimes asked myself, the vengeance of the Semitic race? Are these Numidians going once more to devour their conquerors? Incontestably, in the slow development of the Algerian people, the influence of the Arab will count, not directly, of course, but indirectly. A growing race can no more resist the presence of another, infinitely superior in numbers to its own, than it can resist the ubiquity of the earth and air. Even with the abyss that yawns between the Aryan and the Semitic tradition, the mere fact of inhabiting contiguous spaces of the same continent must tend to modify both.

The French are never weary of talking about the assimilation of the native population, a dream 
which no æons of mutual toleration will ever bring to reality. Between the Arab and the Latin no transfusion of blood is possible, and without ethnological assimilation there can be none in any real sense of the word. Influence, however, there may and must be, and in their efforts to civilize the Arab, the French often forget that such action is invariably reciprocal. When you talk with an officer who has spent years of his life in the Bureaux Arabes, in constant and friendly touch with the natives, you perceive at once the action of the environment on his opinions and character. A few become more Arab than the Arabs; none are quite the same as they would ctherwise have been. For independence of environment is not a quality of which either the human race or the individual can boast.

In that future when all these diverse Latin elements will have been merged in the Algerian race, what attitude will it adopt towards the native multitudes at its gates? By that time the question as to French and foreign numerical proportions will be dwarfed by the infinitely greater fecundity of the native population. In the census of I9I I the Arabs and Berbers, or Kabyles, counted together, reached the figure of $4,740,526$, which represents an increase of 322,468 since 1906 . Assuming that the total population augments in the same degrees, it is improbable that the number 


\section{EVOLUTION OF THE ALGERIANS 26 ז}

of Europeans in Algeria will exceed I, $, 000,000$ by the middle of the century, as against $8,000,000$ natives. 'To the economist these figures are eloquent. They seem to brand as Utopian any dream of an Algeria peopled, as well as dominated, by a Latin race. M. Leroy Beaulieu frankly renounces any such hope when he writes: "In Africa the French race should act as a ferment, influencing a mass infinitely greater than herself. If France can impose upon Northern Africa her language, her customs, her laws and her tastes we shall have done our work as a civilizing force in the world."

To that end France has laboured, and is labouring, with admirable tenacity, with unexampled generosity. She has grudged neither men nor money to develop and consolidate her African empire. How she will continue her imperial task in the future must depend first upon the Algerians themselves, and finally upon her Moslem subjects. 


\section{CHAPTER XIV}

\section{ALGERIA'S EASTERN NEIGHBOUR}

This short survey of colonial life in Algeria would scarcely be complete without some allusion to the sister state growing up by her side under circumstances at once so different and so similar. Thirty years have elapsed since the Treaty of La Marsa definitely placed Tunisia under the protecting wing of France. As early as 1869 she had, however, in company with England and Italy, intervened in the financial affairs of the Regency, then on the verge of bankruptcy. This triple control was not destined to endure. It aroused, as analogous arrangements have since done in Egypt and in Morocco, a fatal amount of rivalry between the Powers involved. So when the native tribes of Kroumiria raided the Algerian frontier some twelve years later, France seized the occasion to establish herself in the country by force of arms. The fact that Tunisia is, geographically speaking, a mere prolongation of Algeria explains, if it does not entirely justify, this step. The neutrality of Great Britain had been secured at the time of the Berlin Congress, but some 
ALGERIA'S EASTERN NEIGHBOUR 263

acrimony preceded Italy's recognition of the Protectorate, while Turkey's acquiescence was only implied in 1892 , when she consented to delimitate the Tripolitan frontier as far as Ghadames.

The firstfruits of the new order of things were, as might be expected, a reorganization of the machinery of government. This was accomplished without the abdication of the Bey, who still remains the titular ruler' of Tunisia. In practice, however, H. H. Mohammed-en-Nasr enjoys far less power than that other victim of ancestral extravagance, the Khedive of Egypt, to whom His Britannic Majesty's agent in Cairo merely tenders advice. The activity of the Bey of Tunis is confined to signing decrees presented to him by the Resident-General, who initiates all legislation and acts as sole intermediary between the Regency and the Republic. A standing army of about 20,000 men lends weight to M. Alapetite's authority, while a phalanx of secretaries and a Council of Ministers assist him in the task of administration. This Council includes the two surviving members of the Beylical cabinet, or Ouzara, besides the French directors of the different State departments and the general commanding the army of occupation. The year 1896 witnessed the formation of another assembly, called the Conference Consultative, which is elected from among the French inhabitants. Its 


\section{ASPECTS OF ALGERIA}

duty is confined to advising the Resident-General on all matters which affect, or are supposed to affect, French interests. Although it has no power to enforce the adoption of its views, its influence is considerable and not always beneficial to the community at large.

With the laudable intention of avoiding the mistakes committed after the conquest of Algeria, as few changes as possible have been made in the government of the native population. It is carried on, as before, through the medium of Kaids and Sheikhs, though their acts are now supervised by French controleurs, and their functions have become territorial rather than tribal. When the abrogation of the Capitulations necessitated the establishment of French Courts of Justice with all the complicated procedure already acclimatized in Algeria, the native Tunisian was not affected thereby. He is still amenable to the jurisdiction of the Kadi, who continues to dispense justice according to the Koranic law in all disputes where Moslems alone are concerned. But where either litigant or delinquent are of European nationality the case is tried by the French tribunals.

Though happier on the whole than the Algerian Arab, the native Tunisian is equally the victim of excessive taxation, which differs rather in incidence than in degree. His principal grievance is the Medjba, a poll-tax of 25 francs $(£ \mathrm{I})$ which 
ALGERIA'S EASTERN NEIGHBOUR 265

falls upon the whole rural population. $\mathrm{He}$ is also subject to the canoun-an impost similar to the Algerian lezma - which taxes every date and olive tree, the sum varying from 20 cent. (2d.) to I fr. 50 cent. (Is. $2 \frac{1}{2} d$.), according to locality. Another tax is the mradjas, confined, however, to the vegetable gardens of Sfax and Cap Bon; nor do any of these give immunity from the achour, imposable, as in the colony, on every ten hectares of agricultural land. But heavy as these contributions are, the land-tax at least is fairly distributed, European as well as native farmers being liable to it. The same can also be alleged of the numerous indirect taxes and monopolies which burden every resident of Tunisia without distinction of nationality, and which produced in rq 10

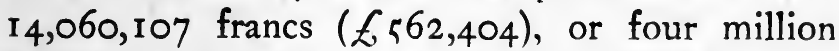
francs more than the direct taxes. In the neighbouring colony these charges are almost unknown. and with such formidable means of raising revenue one is not surprised to learn that the Protectorate has never been a pensioner on the bounty of France. It pays its way, and occasionally terminates its financial year with a balance in hand. That surplus is not, however, sufficiently large or regular to enable the government to lower the Medjba without inflicting a compensating increase in the amount of the taxes paid by the European community. The Resident-General is in favour 
of some reform, but the angry protests of the Conférence Consultative will probably have the effect of retarding, if not of absolutely circumventing, any such scheme for the relief of the indigenous population.

Still less than in Algeria does there exist any sympathy between the average colonist and the native race. The colonization of Tunisia presents, however, idiosyncrasies which are entirely absent from the Algerian problem. The fact that the protecting Power possessed no land in the Regency saved it from the expedient of free concessions. But, apart from the 5000 square kilometres of inalienable forest, the Beylical domain comprised large areas of unoccupied territory. These were available for colonization, but only through the usual method of sale and purchase. Thus the officially created village inhabited by emigrants from France is totally absent from the Tunisian landscape, and even the small farm is rare. "Tunisia has been colonized," as Professor Girault points out, "but not by the French peasant." The initiative was in this case taken by enterprising capitalists in search of a good investment. Immense estates were acquired by corporations whose shareholders were not afraid of sinking considerable sums to plant vineyards in the north or olive gardens in the south. The country has, therefore, been exploited, but in a 


\section{ALGERIA'S EAS'TERN NEIGHBOUR 267}

manner which has reduced the number of French colonists to a minimum.

In order to counteract this concentration of the soil in the hands of a few anonymous and absentee proprietors, the Government achieved in 1900 the creation of a fund entitled the caisse de colonisation. Its object was to devote profits from the sale of urban and other public property to the purchase of undeveloped tracts, which were to be cleared and sold to intending settlers. Payment by instalment was permitted, and during the first five years of its existence the caisse had bought and disposed of 37,200 hectares (91,984 acres) in this way. Every inducement has also been offered to cultivators to reconstitute the ancient olive woods which brought wealth to Roman Byzacene. This land, which is called sialine, from the name of the family to whom it originally belonged, is situated near Sfax, and supports to-day upwards of ten million olive trees.

The report of the British Consul at Tunis for I9I I mentions 25,793 miles as representing the area of land that has passed into the possession of Europeans since the Protectorate was proclaimed. The number of colonists settled thereupon is quoted at 3 I 4 I, of which 2665 are French, Italians and other occupants only reaching a total of 476 . The whole extent under cultivation, by both European and native farmers, is reckoned at about 
I, $, 00,000$ hectares $(2,470,000$ acres). Corn and live-stock cover the bulk of this territory, and represent together $£ 2,340,000$ in the list of exports, or about half the total produce sent out of the country in I9I0. Only about I6,000 hectares $(39,520$ acres $)$ are devoted to viticulture, which is, as in the colony, an almost exclusively French enterprise.

The dread that the proportion of their compatriots will diminish as the affluence of Italians increases is the chief preoccupation of the protectors of Tunisia. To-day not more than 35,000 French share its sunshine with over 100,000 Italians, who predominate numerically like the Spaniards in Oran. The majority of these invaders are Sicilians, who crossed the Mediterranean to supply the manual labour for which the untrained Tunisian was then unfit. They form a sort of imperium in imperio, more or less compact, and are extremely tenacious of their language and national characteristics, as the recent dispute on the subject of Italian schools showed. Nor will they ever be absorbed into a new Latin race, such as is being slowly evolved in Algeria through intermarriage and naturalization. A difference of class, as well as inequality of numbers, prevents any ethical fusion between the Italians and the French in Tunisia, and naturalization, instead of being too easy, is so beset with difficulties that not more than 
ALGERIA'S EASTERN NEIGHBOUR 269

fifty persons per year seek to overcome them. In Italy, on the other hand, these exiles are regarded as lost to the country of their birth, and a hope exists that the stream of immigration may be ultimately diverted into Tripoli. But no future exodus of Italians would now arrest the development of Tunisia, as the Resident-General recently remarked to an interviewer, for every day the trained native workman increases in numbers and capacity.

At the moment of writing the duration of hostilities between Italy and the Ottoman Empire has produced a certain amount of friction between these Moslems and their Italian neighbours. For the protecting Power this animosity has created a delicate situation. It seems doubtful, however, whether the Resident-General took the wisest course in treating the recent boycott of the Italianowned tramways as an explosion of pan-Islamic sentiment. Some expression of sympathy with their co-religionists was natural and inevitable, but in character the Tunisian differs considerably from the Algerian Arab, and still more from the Moor of Morocco. Gentle and refined by nature, he possesses much less energy, and as a rule prefers the studious to the strenuous life. There exists, moreover, in Tunis a leisured class-unknown in Algeria-that was cultured, in the Islamic sense, long before the French opened the gate to the 
science of Europe. Colleges, such as the Khaldounia, founded by the Tunisians themselves for the purpose of disseminating Western knowledge, show that they are anxious to avoid the reproach of obscurantism. The desire to take from Europe only its worst, so lamentably characteristic of the modern Egyptian, is much less evident in this branch of Moslem society. Vulgarity is a failing of which no Arab is capable, least of all the Tunisian, who is a gentleman always and sometimes an exquisite, not without a touch of effeminacy. The bitterness of conquest has not eaten into his soul, and the beauty of Tunis is still all his own, for the French have wisely built the modern town outside the precincts of the old city. Streets are to be seen there that denote a certain reserved opulence, and richly carved doorways ajar on marble courtyards full of flowers. A fair proportion of pedestrians in the Place Halfouaine and the Rue Sidi-ben-Zaid are elegant as well as picturesque, and all have the air of being comfortably at home.

For the tourist the charm of Tunis resides chiefly in its bazaars, which, though less extensive, are as interesting as those of Cairo. They exhibit the beauty and colour of the Orient without any of its ferocity and little of its squalor. I would that I might stroll once more, ere my ultimate robe enshrouds me, down the Souk-el-Trouk, 
where the tailors fashion sleek fabrics into the sombre burnous and the orchid-tinted gandourah. I would that I might taste once more the coffee brewed by the wily Messaoud in the Café des Marabouts before taking sanctuary in the Soukel-Attarin among the captive souls of flowers, where one may purchase with gold a few intoxicating drops of the distilled jasmin for which Tunis is renowned.

To the unbeliever the mosques of the capital are rigidly closed, but the Dar-el-Bey, once the winter palace of the sovereign, is worth a visit for the sake of its tile-encrusted rooms and its view. From its terrace the domed roofs of Tunis appear to ripple away on every hand like an ocean of creamy foam, out of which the minarets surge like beacons. The faith of Islam-one might sayguarding the homes of Islam; and fluttering over both, in the balmy sunset breeze, is the tricolour of France.

When the rather languid grace of Arab Tunis begins to cloy, you can pick up the neat electric train in the Avenue Jules Ferry, which will transport you by La Goulette to Carthage in half-anhour. Disappointment waits, however, on the archæologist who expects to find there any of those eloquent ruins, to whose existence seventeenthcentury travellers bear witness. Of the city whose foundations were laid by the fugitive Queen Dido 
no trace remains to-day. The numerous statues and beautiful mosaics which have rewarded the toil of French excavators have found a home in the Musée Alaoui, spaciously installed in the ancient palace of the Bardo. But no care has ever been taken to protect the site of Carthage from spoliation. The Fort of La Goulette and many of the houses in Tunis were built with marble pillaged from the streets of the illustrious city, and at one time Italian ships in search of a return freight were permitted to take its stones away as ballast. As late as 1904 and I905 large tracts in the vicinity of Carthage were sold as building lots at five francs a metre. The greater part of this land, which includes the Baths of Antoninus and the Circus, has never been explored, and, unless the French administration takes some action, the treasures it may conceal will be destroyed by the dynamite of the speculative builder. Its surface is a precipitate grassy slope, interrupted at intervals by scattered stones, which meanders along the estuary, its summit crowned by a clump of hideous modern buildings culminating in a museum and a garish specimen of Christian architecture-the cathedral dedicated by Cardinal Lavigerie to the memory of St. Louis.

But so tragically potent are the memories which haunt this place that they completely overwhelm the paltry emblems it upholds to-day. Here one 


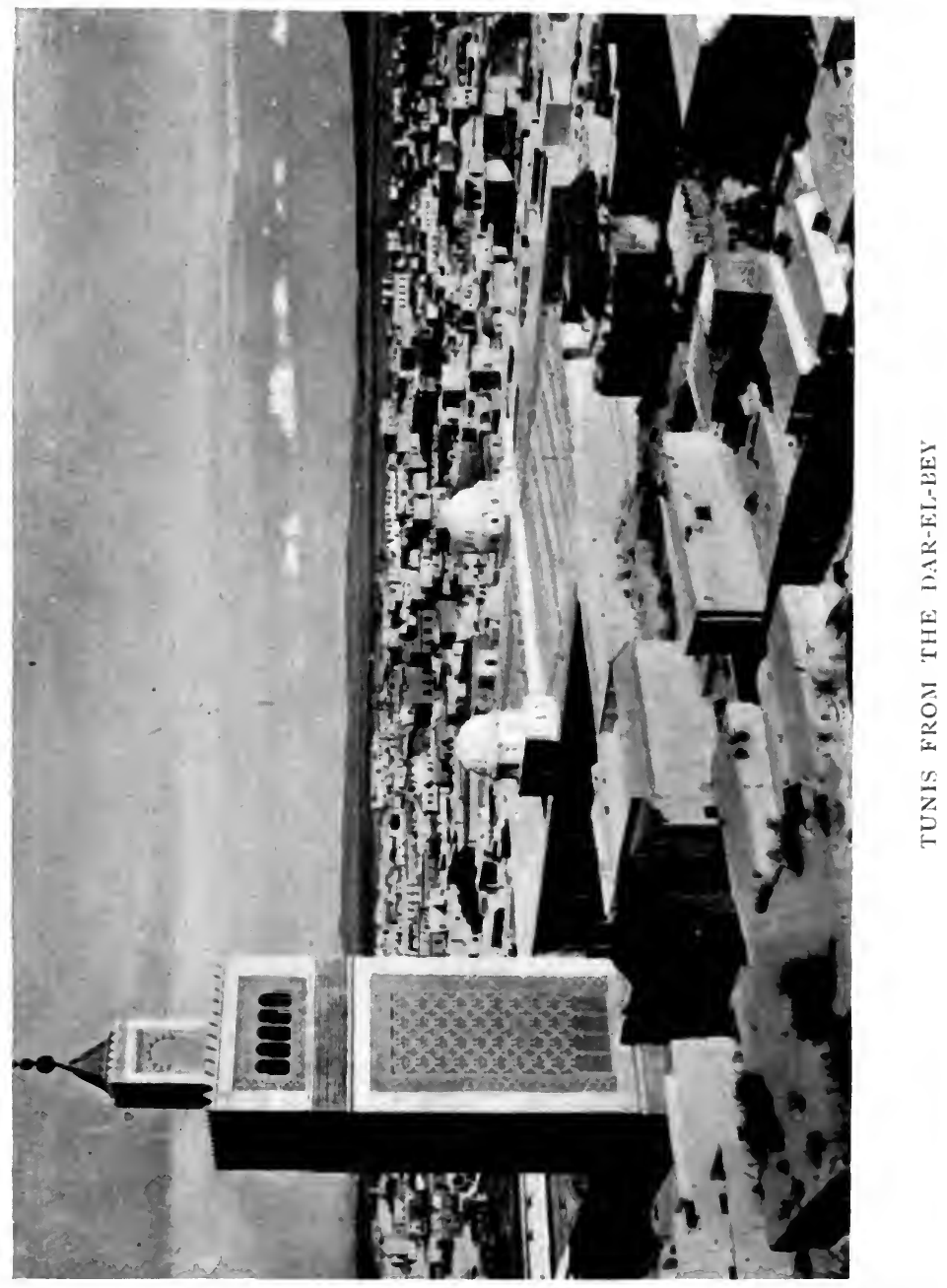



feels the ferocity which Arab Tunis lacks. It seems to shriek from this blood-soaked earth, for nowhere, perhaps, in the world has so narrow a strip of soil borne such a weight of human emotion. One has only to read Appian of Alexandria's chronicle to realize that, in comparison with the struggle which ended in the annihilation of the Carthaginian empire, modern warfare is mere child's play. Standing where men have fought like devils and died like gods, the glory of Carthage seems still as alive as her courage and her despair. In most of the places where history has been made the ghosts of the past wait timidly till you recognize them; here they seize you by the throat. You cannot choose but see great Hannibal gazing with you across the Mediterranean towards the Rome he had sworn to subdue, while on the two-horned Bou Kornein, by the dread image of Moloch, Hamilcar rages yet, unappeased by the crucifixion of his enemies. Athwart the bay creeps the long vertebra of the aqueduct, carrying water to the town of Tunis as it did in Hadrian's reign; and to the left of me, on the very spot where the Chapel of St. Louis rears its cross, the Temple of Fsculapius once surmounted sixty marble steps leading down to the sea. Therein was enacted the last scene of the history of Punic Carthage, when the wife of the traitor Hasdrubal threw her children and herself into the burning shrine. I 
wonder if the echo of her curse ever disturbs the White Fathers at their prayers; or whether the spirits of the martyrs in Roman Carthage-Perpetua and Felicitas, Speratus and Donata-protect their tranquillity?

From the phantoms that people the soil of Carthage a respite may be found in the peace of Sidi-Bou-Said, which overgrows the cliff where the waters of the estuary meet the waves of the Mediterranean. You must climb through a labyrinth of white-walled Arab houses, with swarthy shutters and doors of turquoise, till you reach the little café by the semaphore. Then, seated upon a mat, you may contemplate the greenest sea that ever washed the feet of Africa, and murmur, between sips of inimitable coffee, a placid "Mektoub!"

All over Tunisia, however, the impressions one receives from the "visible fair earth" are stifled by the spectres of the past. Thus the port of Sousse, which somewhat resembles Bougie, is only rescued from mediocrity by the fact that it was once Hadrumetum, and served Hannibal as a base of operations during his campaign against Scipio. I halted there on my way to Kairouan for the purpose of visiting the most imposing relic of Roman rule in Africa-the Colosseum of ElDjem. Its skeleton still defies the teeth of Time upon the desolate steppe, intersected with chotts 
or salt lakes, that stretches between Sousse and Sfax. El-Djem is easy of access by automobile, which devours the flat French road in less than two hours. The gigantic ruin is visible long before you approach it, and the grey skies which overshadowed it on that occasion seemed to rob its stark hemicycle of the African charm of incongruity. I did not ask myself what it was doing there, a giant among pigmy olive trees and the hive of an Arab village; for it required no effort to reconstruct, in the magic mirror of the rain, the prosperous city of Thysdrus, and the 70,000 spectators who thronged the amphitheatre on feastdays. In circumference El-Djem is only slightly inferior to the Colosseum in Rome, and its isolation gives it a greater dramatic value. Until the end of the seventeenth century it was intact, and would probably have remained so had not the reigning Bey-may Allah afflict his soul!-battered down a portion of the wall in pursuit of some rebel tribesmen who had taken refuge within. Traces of another amphitheatre are to be seen beyond the village, and also the remnant of mammoth cisterns, all of which indicates that Thysdrus was a civilized centre about the time when Timgad was but an outpost of the empire.

But the magnet which had drawn me into Tunisia was the holy city of Kairouan. I was, in fact, so intent on reaching it that I turned a 
deaf ear to the suggestion that the oasis of Gafsa was worth a detour, if only on account of the phosphate quarries, 50,000 hectares (I 23,500 acres) in extent, where upwards of 3500 operatives are employed. It was, therefore, inevitable that the town sacred to the zeal of Sidi-Okba-the same who cursed the wells of the Sahara-should fall below the zenith of my hopes. In the first place, the storm-clouds, which harmonized with the classical sentiment of El-Djem, are utterly at variance with the spirit of Islam. Rain does not lend mystery to beauty in the Orient as it does in the North; it merely disintegrates it. Just as the most characteristic expression of the Oriental soul is a kind of impassive ardour, so an atmosphere of torrid calm is essential to the poetry of an Oriental landscape. Though the aspect of Kairouan was less lamentable after the cessation of the rain, I could not help feeling that the glory of Sidi-Okba's fane had departed for ever when a company of French soldiers rode into the courtyard of the Great Mosque.

That intrusion was, as indeed it was meant to be, a blow aimed at the heart of Islam. Its vast and fair proportions are, however, an indestructible title to greatness. One has the sensation of a spacious enclosure full of light,-never, as in our cathedrals, of a lofty house full of shadows. You look around widely, as the Moslem prays, but 
never upwards, as the Christian looks when addressing his Deity. A temple is, in fact, invariably symbolic of the creed which constructed it, whether it be dedicated to Christ or to Mohammed. And as I wandered through the forest of pillars - spoils of Carthage-which edge the aisles of the Great Mosque, I was reminded of Cordova, where a shrine built for the followers of the Prophet has been gaudily Christianized, at the sacrifice of much of its beauty and all of its significance.

With Kairouan one may fittingly close the chapter of Tunisia's past. But a few words remain to be said concerning its future, now more than ever bound up with the colonial destiny of France. Were it not for Algeria, the living nucleus of her African empire, no reason would exist for any change in the platonic relationship she has already established with Tunisia on the one hand and with Morocco on the other. Bound by international pledges, France must, for the present, restrain her aspirations, whatever they may be. To have ousted the most dangerous of her rivals between the Atlantic and the Tripolitan frontier is an achievement whose magnitude will become more apparent with every year that flies, when Spanish pretentions to a condominion in Morocco fade, as they eventually must.

In the meantime there is nothing to prevent 
the Government of the Republic from promoting the interdependence of these temporarily distinct branches of her great African tree, whose roots are already firm in Algerian soil. The most obvious way of achieving this object would be by the establishment of a customs union between the metropolis, Tunisia and the colony into which Morocco might ultimately be drawn. At the moment Tunisia has only been partially admitted to the enjoyment of the reciprocal tariff which exists between Algeria and the mother country. Until I 890 the products of the Protectorate were treated as if they emanated from a foreign land. Subsequently, however, its principal exports were admitted duty free into France, with limitations as to quantity. That restriction was abolished in I 904, but only in exchange for a preference in favour of similar French goods. This was effected by imposing the minimum tax upon foreign products, especially corn, wine and oil, which find their way into Tunisia; and there is every prospect that this tax will be augmented as time goes on. The only objection to entire reciprocity is the increased cost of living, which would be its inevitable result in the Protectorate. Professor Girault, who is one of its advocates, candidly admits that, at least in the beginning, the benefit of such an arrangement would be all on the side of the mother-country. The trend of French policy does 
not, however, indicate that she will continue to respect the natural desire of the colonist for a cheap dinner. And as long as her own blood flows in his veins there is no irrefutable argument in favour of her doing so. But that condition does not exist in Algeria, and still less in Tunisia. Whether their half-assimilated Spanish and Italian inhabitants will consent to buy dear food for the glory of France is a question which only the future can answer.

In any case this problem is not likely to be embittered by competition between the three sister states, for the frontiers which separate them are as artificial as those which delimitate the different provinces of the colony. Nature herself has made the French share of North Africa one. Tunisia and Algeria have the same climate, and the products extracted from their soil are practically identical. As yet Morocco is, agriculturally speaking, an unknown quantity, but her rainfall is superior and her mean temperature lower. Years must, however, elapse, even after the present critical period has passed, before she could become the commercial rival of her neighbours. It may be that no future will ever witness a federation of the North African states such as has been recently inaugurated on the southern edge of that continent, where the climate is very similar. But if any effort is ever made by France to unify the 
interests and administration of " the three Mauretanias," the first step towards that end will obviously be an eastward and westward extension of that reciprocal tariff which regulates the commercial relations of the metropolis with Algeria. 


\section{CHAPTER XV}

THE FUTURE OF ALGERIA

IN considering the position which Algeria wili eventually occupy in the colonial empire of France, it was formerly necessary to envisage the possibility of a definite check to the unification of the three Latin races who people it. Previously to the recently signed convention with Germany which gives France a practical protectorate over Morocco, such a check might have come at any time through the establishment of another European power in the Sherifian empire.

Until the conclusion of the Anglo-French agreement in 1904 the policy pursued by Great Britain constituted an effective bar to any wide extension of French influence in that direction. A little more than two centuries ago Tangier formed part of the dower of Charles II's Portuguese queen, and the importance to us of its possession, or at least of its neutrality, was never disputed. It was reiterated by Lord Nelson and constantly emphasized by our famous ambassador to the Court of the Sultan, Sir John Drummond Hay, who on one occasion styled himself the "Sentinel of the 
Straits." It was, in fact, the situation of Tangier opposite Gibraltar which, far more than any other consideration, determined the trend of policy which we abandoned five years ago in order to cement the friendship of our nearest neighbour. Nor is it any depreciation of the inestimable moral value of that friendship to describe the convention of 1904 as a triumph for the diplomacy of M. Delcassé.

The mingled astonishment and exultation with which its existence was announced by the entire French Press is sufficient indication that, as far as concrete advantages went, we renounced a good deal more than we received. In abandoning illusory fishing rights in Newfoundland France but anticipated the end of an expiring industry. But in exchanging a free hand in Morocco for a free hand in Egypt, Lord Lansdowne gave up a substance for a shadow, as Le Temps frankly admitted at the time. "England," it wrote, "effaces herself in Morocco in order that we may recognize in Egypt what we have not been able to prevent and could not any longer hope to frustrate."

This pusillanimity on the part of our Foreign Office is the more surprising as France was at that moment disposed to agree to the neutralization of Tangier. Such a safeguard of our political rights was publicly suggested by M. Etienne (sometime Ministre des Colonies) in I903, and echoed by 


\section{THE FUTURE OF ALGERIA 283}

other French writers. The terms of the treaty, however (Art. VII), merely express the decision of both Governments " not to permit the erection of any fortifications or strategic works on that portion of the coast of Morocco comprised between, but not including, Melilla and the heights which command the right bank of the River Sebou." It is hereafter stipulated that "this condition does not, however, apply to places at present in the occupation of Spain on the Moorish coast of the Mediterranean." There is nothing, therefore, to prevent Spain from fortifying Ceuta, and then handing it over to some European Power whose interests might ultimately become hostile to our own. Such action, needless to say, would be a direct menace to Gibraltar and to the freedom of the Straits which Great Britain is, more than any other nation, concerned to protect.

From the commercial point of view this treaty seems to reflect still less credit upon the sagacity of our Foreign Minister. Our trade with Morocco used to represent more than half the sum total of goods imported into that country. Since the Anglo-French Convention was signed our trade has increased in bulk if not in proportion, and doubtless will increase, with the gradual opening up of the interior so long as we continue to compete with other nations on equal terms. This has been the case in Egypt, where in a fair field 
French exports have consistently dwindled to about one-fourth of our own. Had this equality of opportunity been secured in perpetuity by our arrangements with France regarding Morocco, British merchants would have no reason to complain. But it was only so secured for a period of thirty years. At the expiration of that interval, as we have every reason to suppose, France will take advantage of her firm grip upon the western edge of Africa to close Moroccan ports to British goods by the imposition of prohibitive duties on all but exports from her own shores.

This eventual loss of the whole, nor nearly the whole, of our present trade with Morocco is no pessimistic possibility, but the invariable consequence of French domination in all parts of her colonial empire. In a previous chapter I have shown how British goods have been practically driven out of the Algerian market since 1889 . In Tunis the fifteen years' extension of the open door which Lord Salisbury's diplomacy obtained for our cotton goods ends in 1912, when it is evident that our commerce will be gradually blocked out of the protectorate. In Madagascar two Declarations, the first in I 866 and the second in 1890 , signed by Lord Salisbury and M. Waddington, were insufficient to protect British interests when that island was handed over to the French. In our Consul's report for 1903 he points out that as early as 1892 


\section{THE FUTURE OF ALGERIA 285}

France began to modify the existing tariff "so that the duties on cotton goods and drills, etc., have been so increased that foreign importation is almost prohibited." When I visited Madagascar in 1898 our importation of cotton goods had already fallen from I I,973,000 yards to 354,000 yards.

The eloquence of these facts is irrefutable. To imagine that France will, in dealing with Morocco, depart from her consistent policy is childish. In thirty years' time we shall inevitably lose our hold upon these 300,000 square miles of territory, the richest in Northern Africa, harbouring a population of approximately $10,000,000$ souls, and possibly also our carrying trade along its $I, 300$ miles of coast. It does not quite follow, however, that the whole of this spoil will fall automatically into the arms of the Republic. Even with British pretensions disposed of she has still to reckon with Spain, whose claims on Morocco are centuries older than those of any other European power. Rightly or wrongly, Alphonso XIII is credited with a desire to heal, through the increase of Spanish influence in Morocco, the wounds which the loss of Cuba inflicted on the national pride. The frivolous nature of the pretexts which served for the extension of military operations in 1909 far beyond the zone of the alleged railway concession in the Riff, and for the precipitate occupation of 
Larache and Alcazar in June of last year, seem to give colour to the rumoured royal designs.

So far French interests in Morocco have been more economic than political, and these are already considerable. The actual trade represents each year a sum of about $80,000,000$ francs $(£ 3,200,000)$, or nearly half of the total commerce of that country. Of this sum Algerian trade accounts for $48,000,000$ francs ( $£ \mathrm{I}, 920,000$ ). How far Spanish aggression might compromise that activity was evident after the massacre of the Kebdana tride, whose territory the troops traversed in their southward march. As this tribe regularly supplied the market of Port-say, their destruction was a real blow to Algerian commerce. Nor was glory for Spanish arms the only object of the recent incursion, which coincided with the formation in Madrid of a financial company destined for the exploitation of Morocco. Was it not the mineral wealth of that country which originally attracted the attention of German capitalists whose concessions furnished an excuse for the political intervention of their Government?

It is not, however, from direct action at Berlin that France has at present most to fear. Since the recent diplomatic shuffling of the cards events have concentrated the interest of the game on the Mediterranean seaboard. In Paris, as well as in Algeria, it is now fully realized that, even without 


\section{THE FUTURE OF ALGERIA 287}

the tacit approval of any other Power, Spain alone can do much to frustrate French hopes. It might even do more. The Spanish peril resides not only in a possible deflection of Moroccan trade northward instead of eastward, but in the powerful admixture of Spanish blood in the embryonic Algerian race.

To-day the Spanish population of Oran accepts without question its gradual absorption under French auspices. Every year a greater proportion becomes enrolled among the citizens of France. But if that nation, whose sons all of them were, and whose sons many of them still remain, should establish itself on the adjacent boundary for the express purpose of circumscribing Algerian action, the inhabitants of Oran would find themselves in a very invidious position. The Spanish colonists are at home in Oran, where they are prolific and prosperous. Their exodus would depopulate that province, and their hostility might paralyse the whole colony and force France to adopt a policy quite other than the welcome she has hitherto accorded to all these emigrants alike.

Next to the Spanish the most active section of the inhabitants of Oran are the Jews. The enfranchisement of the entire Israelite population by the decree of 1870 is now universally reprobated. It was due to the astuteness of a Jewish lawyer, who seized the occasion when the attention of 
France was concentrated on her Rhenish frontier to benefit his co-religionists. This measure was, however, violently resented by the Arabs, the more so as the majority of Algerian Jews are uneducated Orientals, occupied in degraded callings and ignorant of the French language. The furious outbreak of anti-Semitism which began in I 897 to convulse the town of Algiers, and which caused the departure of three successive Governors, was one direct result of this precipitate granting of political privileges and the consequent arrogance of the Jewish population. As a body they are, however, loyal to French interests, which are their own. Their vote, in a measure, counteracts the spread of Spanish influence in the electorate, while their commercial aptitude augments the volume of transactions throughout the colony. In Morocco, where they are very numerous, it is not impossible that they may eventually play a part analogous to that which first provoked the French occupation of Algeria.

Since that day her North African dependency has cost France, at a moderate estimate, the colossal sum of four milliards of trancs, or $\mathcal{L}_{160,000,000}$ sterling. In spite of the mystification of official reports, Algeria is still unable to balance her annual budget without considerable, though decreasing, aid from the metropolis. Nor does this contribution include the cost of the Army, 


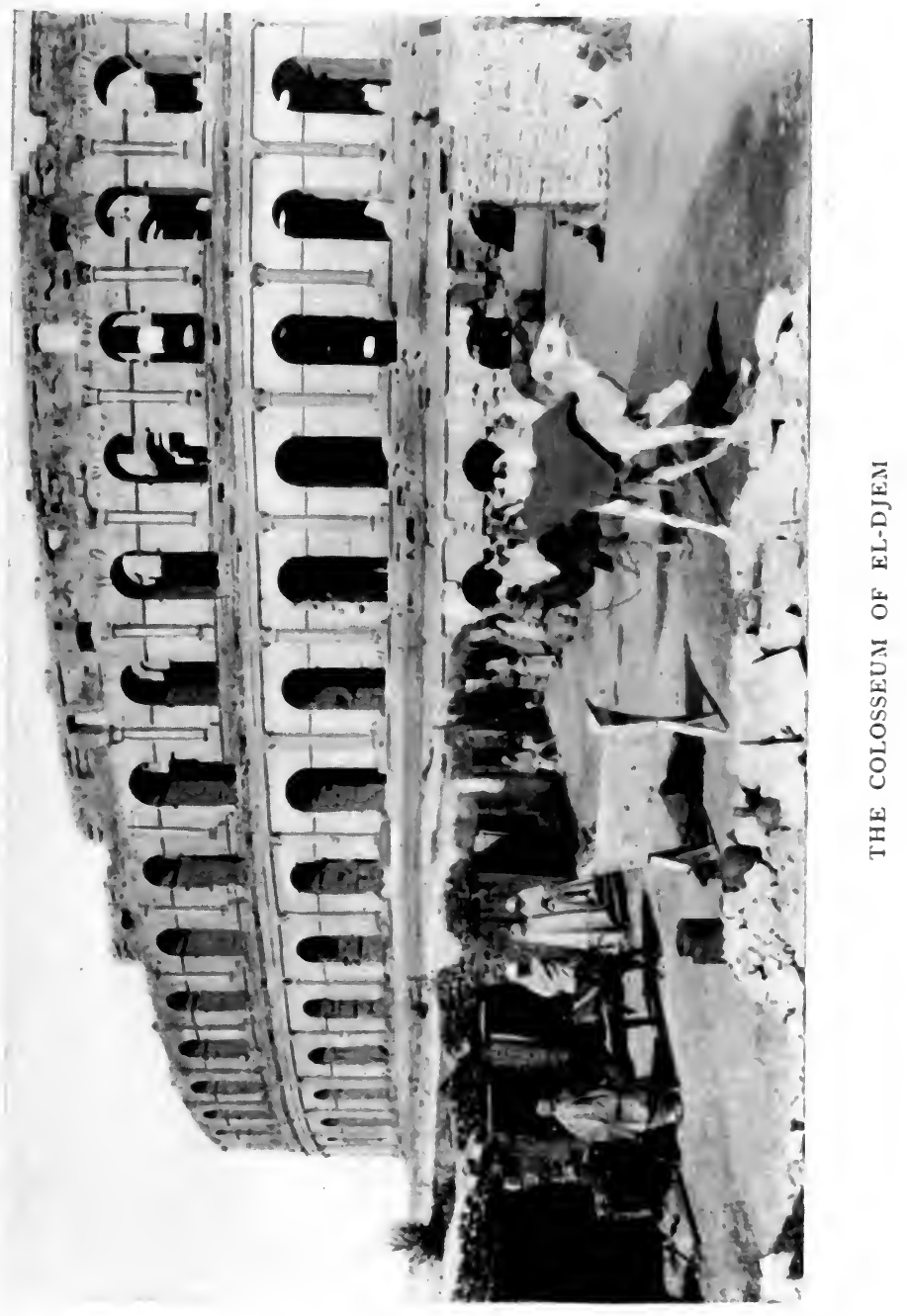





\section{THE FUTURE OF ALGERIA 289}

which necessitates a further yearly subsidy of $55,000,000$ francs $(£ 2,200,000)$. To the English mind, formed on the idea of self-supporting colonies, such generosity is astounding. Its exorbitant cost is, in fact, the chief blemish of French colonial policy. It is costly in every way, but chiefly owing to the complicated character of its administration and the multiplicity of its functionaries. It is no exaggeration to say that in every French colony there are three officials where in British or Dutch possessions only one would be found. The reason of this plethora lies in the fact that the machinery of colonial government is an absolute replica of that which has grown up in the mother-country. Algeria is simply overrun with préfets, sous-préfets, contrôleurs and sécrétaires of every kind and description, employed in a stereotyped routine unsuited to the varying needs of an infant colony. It is this bureaucracy which inevitably produces another of the disadvantages under which the French colonist has laboured. I refer to that absence of local and municipal liberty which was indirectly responsible for the failure of French colonization in the past, notably in the case of Canada.

Time and experience have, of course, modified the rigidity both of the character and of the application of laws framed in and for the metropolis. This is more especially evident in those relating 
to taxation, which are considerably lightened in their passage across the sea. The doctrine of assimilation, which led to the colony being governed for many years as if it were a department of France, has been sensibly relaxed since it was accorded in I90I control of its own finances. This step towards decentralization was taken in response to the urgency of colonial sentiment, and is regarded, not altogether unjustly, as the firstfruits of the law of automatic naturalization. It must not be forgotten that Algeria is, like all the French colonies, represented in the Paris Parliament. Its deputies and its senators exist for the sole purpose of bringing the needs of their far-off constituents to the ear of the central authority. This inclusion in the councils of the Republic, if not exactly a barren honour, is less efficacious than might be thought. Parliamentary time is too precious to permit of its being, except on rare occasions, consecrated to the discussion of colonial problems, especially since the creation, in 1894, of a Colonial Minister, whose attention they are supposed to absorb.

In any analysis of the French colonial system as a whole it must be borne in mind that Algeria differs in many respects from her other colonies. It is neither what M. Leroy Beaulieu calls une colonie de peuplement, by which he means a country almost exclusively inhabited by emigrants 


\section{THE FUTURE OF ALGERIA 29I}

from France; nor une colonie d'exploitation, or a foreign land governed by France and regarded merely as an outlet for her commerce and capital. Of the former kind of colony Canada and Australia are, of course, typical, while the idea of the latter is exemplified in all the Dutch colonies, and in the attitude adopted by Great Britain towards her Crown colonies and India. Algeria, inhabited by a large population of Arabs with an organized society of their own, and yet open to an influx of European settlers, partakes of the nature of both types of colonies. It is precisely this dual character which has rendered the problems that have assailed her administration so difficult to solve. Indecision has consequently too often marred the policy adopted by the mother-country in her regard. Algeria has sometimes been treated as if she were a prolongation of France, and sometimes as if she were bled-el-baroud, the Arab equivalent for the battlefield or no man's land.

France is, however, beginning to realize that the policy of transplanting the political institutions of a European State into a new colony is not the wisest one. She is beginning to realize that there is something, though not everything, in our principle of progressive self-government. In his recent work M. Messimy urges the creation in France of a body of Agents-General representing each colony much as they do in England, and by this means he 
hopes to transform, and in some ways to diminish, the functions of the Colonial Minister. This change he considers necessary in order " to achieve the fortunate evolution of our methods in the direction of decentralization, for each colony should be considered as a distinct organism, complete and autonomous." Such words from the pen of a French official are very significant. If the doctrine of assimilation has been found inapplicable in other colonies-and M. Messimy does not deal specially with Algeria-how much more does this vast North African dependency call for a relaxation of the conservatism which has hitherto characterized its government.

Moreover, if M. Messimy is not unduly pessimistic, the organization of the Colonial Ministry is in urgent need of revision. Although the Republic is to-day inclined towards some measure of decentralization, the machinery of the government department still retains its centralizing character. In spite of the excellent results obtained from the first tentative effort towards increasing the scope of local administration, the passion for unity is so rooted in the Gallic soul that any liberty granted in one direction is nullified by compensating restrictions in another. M. Messimy puts the matter in a nutshell: "The higher functionaries," he explains, "whose duties comprise the local direction of the affairs of our diverse 


\section{THE FUTURE OF ALGERIA 293}

possessions, are neither prefects nor ambassadors. The territories they administer are neither French provinces nor foreign countries. The office of Colonial Minister should not be identified either with the Ministry of the Interior nor with the Minister for Foreign Affairs, although it ought to bear more resemblance to the second than to the first. Actually what do we behold? A hybrid and uncertain organism wherein supervision is mixed up with administration, where bodies with only consultative functions assume tasks which belong to the executive, where officials, material, accounts and the direction of public works are decentralized, and its commercial side ignored altogether."

If this impeachment could not be justly applied to our own Colonial Office, we are yet far from having attained the point of perfect equilibrium between the authority of the permanent officials in Downing Street and the local control exercised by the Colonial Governor. In The Broad Stone of Empire Sir Charles Bruce has recently published the reflections suggested by a long life spent in the administration of our tropical dependencies. Several chapters are devoted to an examination of the defects peculiar to a system in which the responsibility of the resident commissioner is tempered, and his labour often frustrated, by a junior clerk in the Colonial Office who happens to 
be attached to the department which sits in judgment on the affairs of his colony. Even the highest and most conscientious of these permanent officials are devoid of the local knowledge and experience which could alone qualify them to approve or condemn a scheme developed by the man on the spot. This is centralization with a vengeance, and this situation is further complicated by the fact that over the permanent official is the Secretary of State for the Colonies, who frequently knows as little about them as he does about the constitution of his own establishment.

Nor is the influence of the Agents-General, whom M. Messimy is so anxious to adopt, as great as he supposes. They have no power to ensure that adequate consideration is given by the Colonial Office to problems affecting the commercial welfare of the colonies they represent. To remedy these defects Sir Charles Bruce advocates, as Lord Curzon has done on previous occasions, the creation of an Advisory Council, composed of ex-commissioners and others, whose experience would enable them to give valuable information and advice to the Secretary of State as to the actual condition and desires of the Crown colonies and places. These councillors would be equivalent to Agents-General, but in closer touch with the Government, and possessing more authority than these at present enjoy. 


\section{THE FUTURE OF ALGERIA 295}

To return to France, it is evident that no good purpose can be served by an antiquated centralization of executive power whose utility so largely depends upon local knowledge and sympathies. At the same time there can be no question of autonomy for Algeria, in the English sense of the word, as long as the yearly deficit in its budget is made up by the Treasury. Before a colony can detach itself from the mother-country, as Canada and Australia are detached from Great Britain, it must be completely self-supporting. Its revenue must suffice for all its expenses, not only the current cost of its administration, but for the execution of public works, for everything, in fact, except its military defences, which, with its foreign policy, may remain the charge and prerogative of the metropolis. The second condition essential for autonomy is the existence of a homogeneous population. In colonies where the European population-itself composed of different racial elements-is juxtaposed to a nation of natives, such a condition can never be realized. Without the moderating influence of a central power one of two events, or possibly both, would in course of time occur. Either the colonists would oppress the natives, or the latter would band together to exterminate the colonists. Thirdly, some weight must be attached to geographical position. The more distant a colony is from the mother-country, 
the more easy is its adoption of independence for both. Contiguity is apt to render any definite separation inconvenient and undesirable. It is this very proximity, more than any other circumstance, which has influenced for so many years our denial of Home Rule to Ireland.

None of these conditions are as yet present in Algeria, nor in the nature of things can the last two ever be realized there. The existence of five million Arabs occupying the soil with a sprinkling of some eight hundred thousand heterogeneous Europeans, and, added to this, only the Mediterranean stream between the colony and France, makes all talk of autonomy mere empty verbiage. This is not, however, to say that the bonds which bind it to the mother-country should always remain as close as they are to-day. The idea of assimilation which, realized by the Roman Empire, is thus part of the Latin inheritance, is not a changeless, inflexible thing. Like all political ideals, its survival depends upon its power of adaptation to the needs of succeeding generations. Its spirit makes for union, but a union built up out of a large liberty, and a wide tolerance of individual ambition. The controlling hand of the State should become so light as to be almost invisible; a veil should hide the vigilance of its eye. But the task undertaken should never be abandoned unless, as 


\section{THE FUTURE OF ALGERIA 297}

is not the case with Algeria, it can be handed over to ample resources of its own.

Looking at the map of Africa, one is almost surprised to see that the violet hue which indicates the possessions of France extends almost over the whole west. It is broken here and there on the edge by tiny spots of British red, and on its northern shore by the golden stain of a protected Morocco. This border, prolonged by the Spanish strip of coast adjoining the Canary Isles, cuts off Algeria from the Atlantic. South of Rio di Oro is French Senegal, a huge territory only separated from French Guinea by a minute British settlement on the Gambia River and the Portuguese port of Bissago. Another English dependency - that of Sierra Leone-and the free state of Liberia, divide the shore-line of Guinea from the Ivory Coast, where the tri-colour of the Republic resumes its sway. The elongated point of French Dahomey, wedged in between Ashanti, German Togo and British Nigeria, give the hinterland of Mosi and Senegal an outlet to the sea. English red again appears, covering the lower reaches of the Niger River, and extending from the coast to the margin of Lake T'chad. East of it the triangle of the German Kamerun cuts into the French Congo, more deeply since the recent understanding germanized some 100,000 square miles. Northward it melts into Baghirmi and Ouadai, 
recognized as coming within the French sphere of influence by the Convention of 1899 .

The massacre of Colonel Flatters by the Touaregs in 1880 , following on the failure of the Louis Say expedition three years earlier, created a painful sensation in France, which was not entirely obliterated by Brazza's successful exploration of the Congo between 1878 and 1883, and its recognition by the Berlin Conference. The decade which terminated in 1890 saw the birth of the French Soudan, as a result of the splendid pioneer work done by General Faidherbe, by Brière de l'Isle and by Captain Binger. It is to be feared, however, that the individuals who composed the brilliant roll of French explorers were more animated by the spirit of adventure than by any definite plan. They thought more of adding lustre to the glory of French arms than of securing for their country those portions of West Africa most adaptable to exploitation by white men. How, otherwise, was it that Archinard, Audeoud, Soffres and Destenave-only to cite a few of their most celebrated names-gave Great Britain the opportunity of establishing her rights to the watershed of the Niger? This productive territory, which extends from the Gulf of Guinea to Lake Tchad, is as essential to the development of the French Empire in West Africa as the Egyptian Delta is to the British Soudan. 
The failure to bring Nigeria within the French sphere of influence suggested the feasibility of linking Algeria to the Congo hinterland by constructing a railway across the Sahara. A desire to emulate our fruitless Cape to Cairo scheme caused the project of Le Grand Central Africain to be hotly espoused a short time ago by the advocates of an imperialistic policy in France. But the flaw in the British idea also exists in the French plan. Both these ambitious dreams are based upon the stimulation of an artificial current of traffic. There is no reason whatever why any inhabitant should transport either himself or his merchandise from the Cape to Cairo, or from Lake Tchad to the Mediterranean. The natural highway for colonial produce is that which leads most directly from the interior to the coast, because it is the cheapest and the quickest, two reasons which are paramount and ineluctable. Thus economic considerations have diverted political attention to France from the trans-Saharian to the proposed railway, destined to tap the hinterland of Senegambia and find an outlet at Dakar, a newly constructed port on the coast of Senegal. Part of this line is already built, and its commercial utility is obvious. Guinea, the Ivory Coast and Dahomey are already endowed with local lines, and if ever the two railways formerly promised to the French Congo are completed they will presumably drain 
off all traffic and produce north of the area traversed by the Belgian Congo service.

One way still exists by which France may at some future time extend the southern boundaries of her African empire. The abortive negotiations which recently took place between the Foreign Office and the Quai d'Orsay had for their object an exchange of the town of Chandernagor, with about two thousand acres of land surrounding it on the Hooghli, for some portion of British West African territory. A chauvinistic outcry in the French Press caused the negotiations to be abandoned, but it is not impossible that they may one day be resumed. For the conviction is gaining ground among colonial statesmen that the future of Greater France is in Africa and not in Asia. The condition of the French navy renders the problem of protecting colonies so distant from the mother-country as India and Tonquin somewhat difficult of solution. Africa is, on the other hand, relatively near and equally rich, provided that France makes up her mind to sacrifice some portion of her isolated Asiatic dependencies for a larger share of the fertile and populous belt which lies between the Sahara and the Gulf of Guinea.

For the moment, however, these nascent colonies, which can never in any event develop into colonies de peuplement, have few points of comparison with Algeria. The idea of welding 


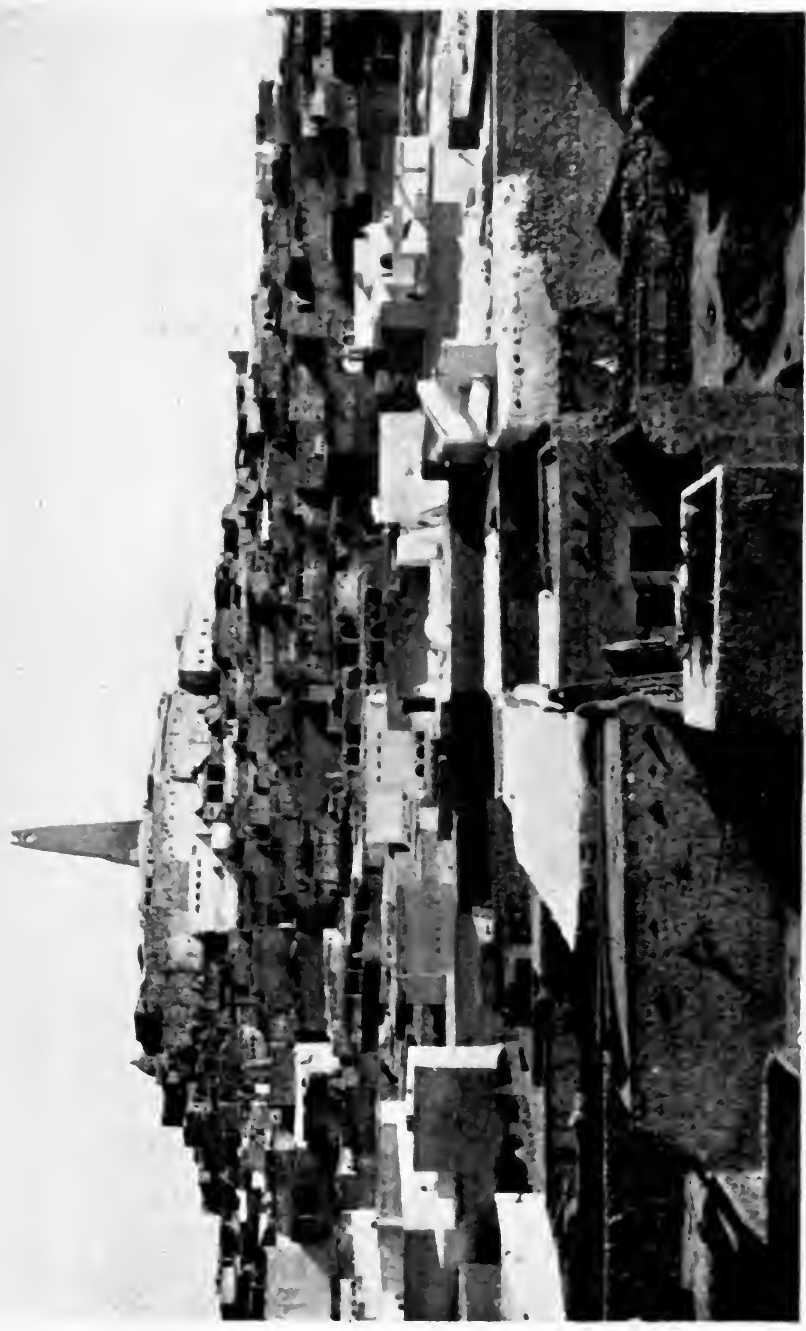

范 



\section{THE FUTURE OF ALGERIA 3OI}

them all into one system, in spite of the intervening desert, is merely another example of the French synthetic faculty, undaunted even by the sternest of Nature's obstructions. But the only union of which Algeria is susceptible is one that will identify her more closely with Tunisia on the east, with Morocco on the west. Relieved from German interference, such an expansion is not only possible, but certain, for the incubus of Spanish inaction carries with it its own death-warrant. The only thing that might indefinitely retard the development and co-ordination of la plus grande France would be a repetition in Morocco of the errors which characterized the conquest of Algeria.

If our neighbours across the Channel seem inclined to examine our treatment of Greater Britain with more sympathy than in the past, it is undeniable that the tendency of our recent dealings with our colonies manifests a desire to cement-I had almost said to recreate-the bond which unites them to us. With them there can be no question of assimilation, for their autonomy has been long since won. But an appreciation of the advantages that may accrue from a closer union with those grown children who are still our kin, advantages to them as well as to ourselves, is the hope that lies behind that correlativelarger, freer, fairer-of assimilation which we call Imperial Federation. 


\section{BIBLIOGRAPHY}

\section{English Works}

The Decline and Fall of the Roman Empire, by Edward Gibbon. (F. Warne and Co.)

The Pilgrimage to Mecca and Medina in 1853 , by Sir Richard Burton. (Quaritch : 1893.)

The Koran, translated by Professor E. H. Palmer. (Sacred Books of the East series.)

The Life of Mahomet, by Sir William Muir. (Smith Elder : 1894.)

The Moors in Spain, by Stanley Lane Poole.

The Speeches and Table-talk of Mohammed, by the same author. (Macmillan : 1895.)

Islam, a Prelection, by the same author. (Hodge.)

Studies in a Mosque, by the same author. (Eden Remington : I 893.)

The Barbary Corsairs, by the same author. (Fisher Unwin: I 890.)

The Moorish Empire, by Budgett Meakin. (Swan Sonnenschein : 1899.)

A Short History of the Saracens, by Ameer Ali Syed, M.A. C.I.E.

The Spirit of Islam, or the Life and Teachings of Mohammed, by the same author. (Calcutta: 1902.)

The History of Latin Christianity, by Dean H. H. Milman. Problems of Greater Britain, by The Right Hon. Sir Charles Wentworth Dilke. (Macmillan : 1890.)

The Broad Stone of Empire, by Sir Charles Bruce, G.C.M.G. (Macmillan : 1910.) 
The Truth about Morocco, by M. Aflalo. (John Lane : 1904.)

The Colonization of Africa, by Sir Harry Johnston. (Cambridge : 1905.)

The Diplomatic and Consular Annual Reports for Algiers, Tunis, Morocco and Egypt. (Wyman and Sons.)

\section{French Works}

L'Islam dans l'Atrique Occidentale, par A. Le Chatelier, Professeur au Collège de France. (Steinheil : 1889.)

L'Islam au XIX ${ }^{\text {me }}$ Siècle, par le même auteur. (Leroux : I888.)

Les Confréries Musulmanes du Hadjaz, par le même auteur. (Léroux : 1887.)

Histoire des Berbères, par Ibn Khaldoun, trad. de Slane. (Alger : 1854.)

Marabouts et Khouans, par le Commandant Rinn. (Alger : 1884.)

L'Islam, par le Comte Henry de Castries. (Armand Colin.)

Les Musulmans Français du Nord de l'Afrique, par Ismael

Hamet. (Colin : 1906.)

La Civilisation des Arabes, par Dr. Gustave Le Bon.

L'Afrique Romaine, par G. Boissier. (1 895.)

L'Influence des Croisades sur l'état des Peuples de l'Europe, par Maxime de Choiseul D'Aillecourt. (Paris: 1 809.)

Description des Monuments Arabes de l'Espagne, par M. Raphael Contreras. (Madrid : 1889.)

De la Captivité à Alger, par Haedo, trad. de M. Moliner Violle. (Revue Africaine.)

Histoire d'Alger sous la domination Turque, par de Grammont. Histoire des Musulmans d'Espagne, par V. Dozy. (Leiden : 1866.)

A verroès et Averroïsme, par Ernest Renan.

Trente-Deux Ans d̀ travers Islam. (1833-1864, par Léon Roches, ancien secrétaire de l'Emir Abd-el-Kader. (Paris : 1884.)

Histoire Privé et Politique D'Abd-el-Kader, par A. de Lacroix. (Paris : 1845.) 
Abd-el-Kader au Château d'Amboise, par Mgr. Dupuch. (Challanel : 1849.)

Rappel a l'Intelligent, Avis à l'Indifférent, par l'Emir Abd-elKader. (Paris Librairie de l'Institut : 1 858.)

Mœurs et Coutumes de L'Algérie, par le Gen. Daumas. (Hachette : 1864.)

Le Grand Désert, par le même auteur. (Paris : 1856 .)

Anthologie de l'Amour Arabe, par Ferdinand de Martino et Abdel Khalek Bey Saroit. (Mercure de France.)

Esquisse Historique de la Musique Arabe, par M. Dumont Schauberg. (1863.)

De la Colonisation chez les Peuples Modernes, par Paul Leroy Beaulieu. (Alcan : 1908.)

Principes de Colonisation et de Législation Coloniale, par Arthur Girault. (Larose : 1907.)

Notre Euvre Coloniale, par A. Messimy. (Larose : 1910.)

L'EEuvre de la France dans l'Afrique Occidentale, per Lucien Hubert. (1908.)

L'Algérie, par Maurice Wahl. (Alcan : 1904.)

La Démographie Figurée de l'Algérie, par le Dr. Ricoux. (Masson : 1 895.)

Le Peuple Algérien, par Prof. V. Demontes. (Alger : 1906.) L'ÉEuvre Française en Algérie, par Raymond Aynard. (Hachette : 1912.)

I.a Tunisie et l'CEuvre du Protectorat Français, par Gaston Loth. (Paris: 1 907.)

La Tunisie Française : Publication du Gouvernement Tunisien.

(Paris : 1895.$)$

Exposé de la Situation Générale de l'Algérie.

Statistiques sur la Commerce de l'Algérie.

Statistique Générale de l'Algérie.

Exposé de la Situation Générale des Territoires du Sud.

(Publications annuelles du Gouvernement Générale de l’Algérie.) 




\section{INDEX}

AbBasides, 61

Abdat-Missoum, Kaid, 190

Abd-el-Kader, the Emir, 99, 120 , $121,122,123,124,125,126$, $127,128,129,135,159,160$, $186,187,241$

Aboukir, 34

Abou Llassen, 100

Abou Yacoub Youssouf, 100

Eneas of Gaza, 54

Atius, 50

Africa, 4, 40, 48, 60, 67, 117,166 , $183,186,189,210,213,221$, 258, 297, 300

African coast, 26

Church, 48 colonies, I 53, I 54

Continent, 162

Agadir, 99

Akhbar, the, 92, 173

Ain-Azem, 190

Ain-Mahdi, 122

Ait-Fraoucen, 27

Ait-Iraten, 27

Aix, 214

Alapetite, M., 263

Alcazar, 286

Alexandria, 124

Alexandria's Chronicle, 273

Alger, 4, 195

-, French, 5, 12, 133

Algeria, 3, 8, 17, 29, 36, 37, 41, $58,59,69,71,86,87,89,92$, 93, IOI, I10, III, I14, I15, 119, 121, 124, 131, 132, 136, 139, 141, 146, 148, 149, 153, $155,156,157,158,159,161$, $164,166,174,175,176,177$,
Algeria, $180,181,183,187,188$, 198, 199, 200, 201, 202, 203, 204, 205, 206, 207, 208, 209, 210, 233, 238, 242, 245, 247, $248,249,250,251,252,253$, $254,257,259,261,262,263$, $264,268,269,277,278,28 \mathrm{I}$, $284,286,288,289,290,297$, 301

$\longrightarrow$, Governor-General of, 13

- Hinterland of, 128 , native races of, 30

Algerian agriculture, 172, 173 , 178, 179, 212

- cotton industry, 169, 170 Parliament, I 35

tobacco factories, 109,170 wine, 165,166

Algerines, II 4

Algiers, 14, 17, 19, 23, 37, 54, 88, 92,98 , 105, 107, $116,117,119$, 122, 139, 182, 210, 214, 215, 217

—, Corsairs of, 107

-, women of, 7,11

Allah, 3, 20, 21, 64, 89, 275

Almoravide conquerors, 99

Alphonso XIII, 285

Alsacians, the, 243

Ameer Ali, 7I

America, 112, I15, 148, 174, 207, 246

Amiel, I

Amin, the, 31

Andalusia, 76, 99

Antar, 84

Antony, 25

Appian, 273 
Apuleius, 24

Arab architecture, I3

- art, 90

- cemetery, 19

- chivalry, 84

- civilization, 25

- houses, 15

- music, $86,87,88$

- needlework, 93

- poetry, $83,85,86$

- schools, 132

- society, 132

- troops, 125 villages, 133

Arabic characters, 37

- tongue, 36

Arabo-Berber women, 7

Arabs, the, 7, 8, 10, 12, 16, I8, $23,27,29,30,36,38,40,58$, $64,76,85,93,95,96,97$, I 10, I1 $8,127,128,129,132,139$, $142,143,147,148,149,15 \mathrm{I}$, 156, 162, 176, 190, 19I, 192, $211,224,237,238,259,260$, $273,275,288,291$

Arch land, 131, 132

Ardennes, the, 138

Arian controversy, the, 48

$\longrightarrow$, doctors, 53

Arians, the, 76

Ashanti, 297

Asia, 60, 75, 90, 300

- Minor, 110

Athanasius, 53

Atlantic, the, 25, 105, 277, 297

Atlas Mountains, the, 29, 34, 52, 184

Aude, 243

Augustine, St., 20, 25, 47, 49, 5 I Augustus, 25

Aures Mountains, 45, 57, 162, 195, 216, 224

Australia, 295

Avenpace, 75

Averroes, 75, 8I

Avicenna, 96

Ayata, oasis of, 235

Ayesha, 73

Aynard, M. Raymond, 78, 79, 80 Azerou-Tidjer, 34
Azerou-n-Tirourda, 34

Baba-Roudj (Barbarossa), 26, I02

Bab-Azoun, 93, 215

Bab-el-Babor, 35

$\mathrm{Bab}$, the, 64

Bacri, Jacob, I 17

Bagdad, 84, 96

Barbary, 5, I8, 37, 104, 106, I I 5

Barry, M., 43, 45

Basilica, the, 55

Baths of Antoninus, 272

Batna, 4I, 42

"Battle of the Camel," 73

Beaulieu, M. Leroy, I47, I49, I6I, 210

Bedouins, the, ro

Belcourt, 18

Belfield, H. C., 196

Belgian officials, 74

Belyium, 29, 166

Belisarius, 56, 57

Ben-Aben, Madame, 93

Ben Choucha, 240

Beni-Sguem, 39

Beni-Yenni, 27, 29

Berber constitution, 3I

Berbers, the, 21, 24, 25, 26, 27, $29,32,36,37,38,39,58,6$, I IO, 219

Bergson, M. Henri, 78

Berlin, 286

Berrouaghia, 39, 183

Berryan, 39

Bertillon, Dr., 25I

Bertrand, M. Louis, 258

Bey Boumezrag Ali, I90

Beylical cabinet, 263, 266

Biskra, 16, 209, 21 .5, 222, 240

Bissago, 297

Bledah, 19, 20, 183

Bled-el-Islam, I30

Bobadilla, 5

Boghar, 122, 184, I86, 187, 199

Bokhara, 90

Bombay, 182

Bonhoure, M. and Mme., 239

Boniface, Count, $5^{\circ}$

-, Empress Placidia, 5

Bosphorus, the, 19 
Bouches-du-Rhine, 243

Bougie, 26, 34, 37

Bougzoul, the desert of, 184,185 , 186, I89

Bou Kornein, 273

Bou-Nourah, 39

Brazza, 298

Breton fishermen, 243

British Guiana, 154

Bruce, Sir Charles, 293, 294

Bruges, 20

Buddhism, 31, 6I

Buddhist Order of Yoga, 64

Bugeaud, General, 122, 123, 125, I 32

Byzantine army, $5^{8}$

- Empire, 6I frescoes, II models in art, 91

Cæsarea, 25, 46

Casars, the, 20, 24, 25

Caird, Professor, 78

Cairo, 14, 89, 96, $214,263,270$, 299

Calabria, 244

Calat-Ayub, 9 I

Caliphate, the, 61

Campagna, 244

Canada, 161, 175, 289, 295

Canary Islands, 297

Canoun, the, 265

Cap Bon, 265

Cape Coast Castle, 195

Carthage, 24, 51, 52, 53, 56, 272, 274

Carthaginian Empire, 273

Carthaginians, the, 22

Castiglione, 54

Catholic Church, 247, 248, 256, $257,258,259$

Cazelles, M., 194

Central Africa, 67, 2 I I

Cervantes, 108, 109

Chaabat-el-Akra, 35

Chambre des leputés, 17, I 24, 204

Chandernagor, 300

Chapel of St. Lows, 273

Chardenet, Commandant, 147
Charles V, 5, 26, 103, 104, 105, 114

Charles X, II7

Charveriat, 31

Château d'Amboise, 127

Chebka, 38, 39

Chegga, 223

Chelitf, plain of, 122, 163, 247

Chellala, the, 41

Chemin des Consuls, 16

Chenoria, 54

China, 90, 91

Chott Merouane, the, 225, 240

Christ, 17, 23, 79

Christian Church in Africa, 25, 80

Christianity, 76, 77, 79, 80, 81, 82, $85,96,100,104,125$

Chrysostom, St., 72

Cicero, 127

Circumcellions, 49

Cirta, 25, 46

Clauzel, General, I19, 121

Cleopatra, 25

Col de Tirourda, 33

Cole, Consul, I 13

Colosseum of El-Djem, 274, 275

- in Rome, 275

Compagnie Algérienne, 212

Compagnie de l'Oued-Rhir, 23

Conference Consultative, 263 , 266

Congo, 74

-, Belgian, 300

—, French, 297, 299

Conseil Superieur du Gouvernement, 134

Constantine, 46, I I I, 139, I80, 204, 244

Constantinople, 52, 54, 56, 76, 101, 103, 104

Cordova, 84, 89, 96, 277

Corniche of the Riviera, 36

Cornu, M., 237

Corsairs, the, 26, 107, I12, 117

Cote d'A zur, 215

Credit Agricole Mutuel, 212

Crkdit, Foncier d'Algirie, 212

Cromer, Lord, 7 I, 144

Cuba, 285 
Curzon, Lord, 294

Cyprian, Bishop of Carthage, 47

Dahlia, 189, 194, 196

Dahomey, 297, 299

Damascus, 6I, 84, 9I, 96, 124 swords, 97

Damiette, 183

Dante, 79

Dar-el-Bey, 27 I

d'Aumale, Duc, I 24

Daumas, Gen., 126

de Bourmout, General, I I8, I 19

Declassé, M., 282

Defile of Death, 35

Delégations Financières, 134

de Mezieres, M. B., 233

Démographie figurée, 243

Demontes, Professor V., 243, 248, 250, 25I, 255

Derbouka, the, 88

Dervishes, the, 65

Descartes, 21, 75

Desmichels, General, I 20, 12 I

de Staël, Mme., 222

Desvaux, Col., 220

Deval, I 16, I 17

Dïa, the, 220

" Diana surprised in her Bath by Acteon," 46

Dickinson, Lowes, 82

Dido, Queen, 23, 272

Diocletian, 48

Divine Comedy, the, 79

Djamma, 227, 237

Djebel Ouenza, the, 204, 205

Djehad, the (Holy War), 66

Djelfa, 183,184

Djemma, the, 31, 32

Djidjelli, 35, 195

Djurjura, 26, 28, 29, 32, 34, 35, 36

Donata, 274

Donatist sectarians, the, 48,51

Donatus, 49, 52, 53

Don John of Austria, I09

Doria, Admiral, 103, 108

d'Orleans, Duc, I 22

Douars, the, 193

Dragut Reis, 106
Drôme, 243

Drouet d'Erlon, Gen., I I9

Duperré, Admiral, I I 7

Duquesne, Admiral, 106, 107

Dutch, the, 208, 289, 291

Eastern Empire, the, 55

Edrissi, 9I

Egypt, 61, 65, 69, $71,72,73,89$, 93, I39, I4I, I44, I50, I 57, $158,168,174,175,212,213$, 2 I $5,233,255$

El-Atef, 39

El-Berd, 226

El-Biar, I 5

El-Djem, 276

El-Djezair, 4, 5, 7, 13, го1, 102, 103, 105, 106, 107

El-Eubbad, Ioo

El-Kantara, 216, 221, 240

El-Kettar, I8, 2 I

El-Mamoun, 95

El-Mansourah, 99

Eloge d̀ la Sahara, I27

"Elopement of a Nereid," the, 46

El-oued, 9

England, 78, I07, I 1 2, I 58, 196, 205, 233, 246, 262, 289

Est-Algerien, the, 37

Etienne, M., 178, 282

Etruscan, 9I

Ettijania, 233

Europe and Europeans, I3, 15, $65,68,72,76,79,80,92,95$, 96, 97, IOI, I I 2, I1 7, I62, I73, 176, 177, 187, 188, 192, 196, 21 2, 236, 244, 249, 251, 253, 259, 265, 269, 270, 295

European merchants, 23

- races, 23

Eusebius of Cæsarea, 48

Exmouth, Lord, I07, I I2, I I4, I 5

Father Dan, I09

Fatigue du Nord, 222

Fatima, 10

Fatimites, 6r, 76

"Faustina," 43 
Faustus, 46

Felicitas, 274

Fellaheen, the, 70

Ferdinand, 75

Ferrero, Guglielmo, 21 7, 218

Firmus the rebel, 46,50

Flatters, Col., 298

Florence, 92

Fort 'Empereur, I05

Fort-National, 24, 26, 28

"Fountain of Peace," the, 22 I

France, 17, 85, 89, I I 7, I 21 , 131, I35, 1 $36,155,1_{56}, 1_{57}, 1_{64}$, 165, 1 76, 203, 205, 207, 245, 26I, 262, 278, 279, 281, 282, $285,287,288,290,291,295$, 297

French Senegal, 297

$\longrightarrow$, the, I3, 20, 26, 27, 38, $64,116,123,159,160,173$, 176, 177, 1 78, 182, I87, 203, 209, 226, 233, 236, 237, 243, $251,252,254,260,263,264$, 269, 270, 275, 289, 290, 297

Gafsa, oasis of, 276

Galileo, 80

Gallifet, Gen. de, $24^{\circ}$

Gambia River, 297

Gandourah, the, 30

Gard, 243

Garden of Allah, the, 221

Gaul, 47, 85

Gelimer, 56

Genoa, 102

Genseric the Vandal, 50, 51, 52, 55

Germany, 27, 88, I66, 205, 207, 209, 246

Ghadames, 263

Ghardaia, 38, 39

Gharnata (music of Granada), 87

Giaccobbi, M., 189, 192

Gianettino Doria, 106

Gibbon, Edward, 48, 5 I

Gibraltar, 107, 205, 282, 283

Gildo, 50

Giralda, the, at Seville, 89

Girauldt, Professor, I35, 266

God, 63, 64, 65, I29, 190
Gorges de la Chiffa, 184

Goths, 76

Gourara, 231

Grand Central Africain, 210 , 2 I I

Great Britain, 295

Greater Britain, 301

Great Mosque, the, 14

Great Wall of China, 63

Greece, 75

Gregory Nazianzen, 49

Gsell, M. Stephane, 94

Guelt-es-Stel, mountains of, 186

Guinea, 297, 299

Habous, the, I3I

Hachems of Medina, 120

Hadrian, 273

Hafecide Empire, the, 35

Hakim II, 84

Hamada, the, 223

Hamet, M. Ismael, 25

Hamilcar, 273

Hannibal, 273, 274

Haroun-al-Kaschid, I 56

Hasdrubal, 273

Hassan, 63 the Eunuch, 104, I05

Haute-Savoie, 29

Hay, Sir John Drummond, 28I

Herat, 90

Hérault, 243

Hercules, 21

Hichens, Robert, 215

High Plateau, the, 36, 162, 193, 194, 195

197, 198, 199, 250, 251, 259

Hippo, 49, 5 I

History of the Berbers, IbnKhaldoun, 21

Hobbes, 75

Holy War (see Djehad)

Honorius, Emperor, 5 I

Hooker, Sir Joseph, 198

Hosein, 63

Hubert, M. Lucein, I 37

Humboldt, 75

Hunneric, 52, 53

II ussein-Dey, 4, 5 
Ibn Touloum, the Tartar, 89

Imperial Federation, 30I

Imr-el-Kais, 85

India, 63, 71, 9I, 96, 197

Insalah, 232

Ionian Greeks, women of, 72

Irak, 9I

Isabella, 75

Islam, $7,19,39,59,60,62,63$, $64,67,68,69,70,71,72,75$, $76,77,78,79,80,81,83,89$, $90,91,92,95,96,100$, 10I, $136,138,157,158,190,219$, 269, 271, 276

Isly, battle of, 123

Ismail Hamet, 7 I

Italy, 63, 84, 89, 167, 247, 248, $249,256,257,262,268$

Ivory Coast, the, 297, 299

Janissaries, the, I 10

Japanese Cult of Ancestors, 3 I

Jesus, 51,76

Jews, the, 40, I16, 135, 287, 288

Johnson, Dr., 75

Jonnart, M., I3, 92, 172

Juan Gil, Father, I09

Jubal II, 25

Judaic, 60

Jugurtha, 2I

Jus, M., 22I

Justinian, 56, 57, 58

Kabyle, political customs of, 30 villages, 29 women, 30,32

Kabyles, the, 22, 23, 26, 27, 28, $32,34,36,118,122,132$

Kabylia, 25, 26, 27, 28, 29, 36, $37,135,146$

Mountains, 168

Kadriya Order, the, 64, 66, 67

Kahina, the prophetess, 58

Kairoûan, 89, 220, 275, 277

Kait Bey, 89

Kamendja, the, 87

Kamerun, German, 297

Kant, 127

Kasbah, the, 5, IO, I3
Kbail, 23

Kebdana, the, 286

Kef-el-dor, 223

Kerrata, 35

Kew, Royal Botanic Gardens at, 198

Khalifa, 123

Khamissa, IO, II

Khammes, the, 237

Kharedjites, 6I

Khedive of Egypt, the, 263

Kheir-el-din, 26, 102, I03, I04, 106, 109

Khelouatiya sect, the, 65

Khouans, the, 65

Knights of Malta, the, I04

Koran, the, 20, 25, 31, 32, 59, 60, $63,71,78,83$, I00, I0I, I6I

Ksour, the, 184

La Depêche Algérienne, I4

Laghouat, 39

Lalla-Khadidja, 34

Lamoricière, Gen., 23, I23

Lane-Poole, Stanley, I07, II I

Larache, 286

Lavigerie, Cardinal, 258, 272

Le Chatelier, M.A., 67, 68

Lecky, 72

Leptis, 25

Le Peuplement Algérien, 243, 254

Les Musulmans Français du Nord de l'Afrique, 25

Letourneux, 193, 194

Lezma, the, 146, 265

Liberia, 297

L'Islam dans l' Afrique occidentale, 68

Liverpool, 182

Locke, 75

L'auvre de la France dans l'Afrique occidentale, 137

L'auvre française en Algerie, 78

London, 207, 236

Louis Napoleon, 124, 125

- Say expedition, the, 298 XIV, 5, 84, 106

Luciani, M., I47

Madagascar, 285 


\section{INDEX}

Maghzen, I I I, I 8

Mago-Zoroastrian Persia, woman of, 72

Mahdi, the, 64,65

Maison Cantonnitre, 34

Malacca, 198

Malta, 205

Mandés, the, 67

Manichæan Yaulicians, the, 76

Mansel, Sir Robert, 106

Marabouts, 64

Marcellinus, 54

Marcus Aurelius, 43

Marseilles, 176, 182

Martel, Charles, 76

Mascara, 122

Massinissa, 22

Materia medica, 96

Mauresque, the, 7

Mauretania, 25, 44, 50, 5I, 52, $56,57,61,217,280$

Mauritius, 154

M'Barka, 9

Mecca, 10, 61, 64, 97

Medeah, 183

Medersas, the, 139

Medina, 6r

Mediterranean Sea, 4, 24, 46, 65, I06, I I I, II 5, I80, I81, I89, 206, 217, 225, 244, 256, 268, 273, 274, 286, 296, 299

Medjba, the, 264

Mehemet Ali, II7

Melika, 39

Melk land, 131, I32

Memlinck, 20

Merinides, the, 20

Mesopotamia, 9 I

Messimy, M., 2 I I, 292, 294

Mezomorto, 106, 107

Michael Angelo, 89

Michelet, 28, 29, 33

Mirabeau, I 52, 153

Mississippi, the, I 7 I

Mitiaja, plain of, 122, 160, 162, 175,247

Moes, 79

Moggar, 228

Moghreb, 6r, 98, ror

Moghrebin Empire, 125
Moguls, the, 63, 75

Mohammed, 17, 19, 59, 60, 63, $65,69,70,71,72,73,74,76$, $83,87,90$, I I 2,190

Mohammedan faith, 80

Mohammedans, 67, 68, 69, 70

Mohammed ben Driss, Capt., 240, 24 I

Moloch, 273

Mongolia, 9I

Montanists, 76

Montgorno, 184

Montille, M. and Mme. de, r 84

Moorish architecture, I4

- Empire, 99

Moors, the, 8, 86

Moqaddem, 64, 68

Morocco, 94, I01, 122, I 57, 161, 175, 206, 269, 277, 282, 283, $284,285,286,297,3$ or

-, Emperor of, 123

Morris, William, 92

Moslem Conquest, 20

- doctors, 63 subjects of France, 13 women, 32

Moslems in India and China, 63

-, schismatic, 38

- , the, 25, 61, 63, 65, 67, 71, $73,74,75,78,81,91,94,95$, 130, 131, 138, 140, 141, 146, 148, I 49, I 50, I 5 I, I 52, I 55 , $156,269,276$

Mostaganem, 122

Mozabites, the, 38, 39, 40, 175

M'rhaier, oasis of, 226

Muir, Sir William, 59

Musée Alaoui, 272

Mussulman, the, $8 \mathbf{2}$

Mustapha, 15, 17, 18, 20, 92, 94, 214

- ben Ismail, Bey, I 20, I 2 I

M'Zab, 38, 39.

Naples, 108

Napoleon III, 132

Nederlands Line, 214

Nelson, Lord, 28I

Newfoundland, 282

Nietzsche, 2 I 
Nigeria, 297

Niger River, 297, 298

territory, 68

Nile, the, 89, 21 5,233

Nineteenth Army Corps, I 54

Norddeutsche Lloyd Line, 2I4

Norman farmers, 243

Northern Africa, 173, 217, 218, 279, 285, 288, 292

Norway, 29, 208

Notre Dame d'Afrique, 16

Notre CEuvre Coloniale, 2 I I

Noubahs, 86, 87

Numbidha, 46, 49

Numidians, the, 21, 24, 51, 52

Odjac, the, III

Omdurman, 64

Ommeyades, 84

Oran, 118, 1 20, 121, 126, 131 1 178, I 79, 195, 207, 248, 268, 287

Order of the Tidjania, 230

Origen, 47

Orléansville, 171

Ostend, 214

Ottoman Empire, 23

- rulers, 26

Ouargla, 2 I0

Oued-Khir, 220, 222, 224, 228, $229,235,237,238,239,24 \mathrm{I}$

Oued-Sahel, 34

Ouled-Antar, the, 187

Ouled-Aziz, 190

Ouled-Hellal, the, 190, 192, 193, 233

Ouled Nails, the, 9, 184

Ouled-sidi Cheikh, I 35

Ourir, oasis of, 225, 239

Ourlhana, oasis of, 227-237

Pallas Athene, 2 I 8

Palmer, Professor, 83

Paracelsus, 96

Paris, 80, I17, I29, I 34, I 52, I68, 236,286

Pathans, the, 63

Paul de Saint Victor, 128

Pedro da Navarro, 17, 26, IOI

Peebles, I87

Pein, Capitaine, 232
"Pelissier" seed, I72

Peñon, 16, 17, IOI

Pera, i 16

Perpetua, 274

Persia, 63, 64

Persian art, 90

Peules, the, 67

Peyerimhoff, M., I6I

Phoenicians, 23, 24, 38

Piedmont, 244

Pilgrimage to Mecca and Medina, 85

Place du Gouvernement, I4

Playfair, Sir Lambert, 16, I16

Polish art, 9I

Port Mahon, 107

Private and Political History of Abd-el-Kiader, 125

Procopius, the Chronicle of, 57

Propriéte Trémaux, 55

Provence, 15, 243

Punic Carthage, 273

Pyrenees, the Eastern, 243

Quai d'Orsay, 300

Rebad, the, 87

Refaiya, the, 66

Reformation, the, 76

Régie, the, 169

Renan, 22, 80, 82

Restitutus, 54

Revue du Monde Musulman, 67

Rheita, the, 87

Ricoux, Dr., 243

Riff, the, 285

Rio di Oro, 297

Riviera, the, 214

Roman Africa, 25, 218

- Carthage, 274 consuls, 23

- Empire, 4I, 46, 47

Romanesque, the, 89

Romans, the, 21, 24

Romanus, Count, 49

Rome, 24, 25, 44, 52, 91, 92, 138 ,

273

, civilization of, 46

Roncevaux, 85

Roumania, 207 
Royaume Arab, 132

Rozet, M. Albin, 142

K'tassin, the, 219, 220

Rue de la Marine, I4

Rue des Sarrasins, 5

Russia, 197

Russian art, 9I

\section{Saada, 223}

Sabega, I3I

Sahara, the, $9,20,29,57,87,135$, 147, 161, 185, 209, 210,211 , $219,221,224,225,229,230$, 231, 232, 233, 236, 239, 240, 276, 300

Sahel, the, 54

St. Jean d'Acre, 124

St. Louis, 272

"Ste. Maria des Tringlots," 226

St. Paul, 127

St. Praxed, Bishop of, 19

St. Salsa's Church, 55

Salah, 106

Salisbury, Lord, 221, 284

Sallust, 2 I

Saracen art, 89

Saracens, the, 26

Scandinavian art, 91

Scipio, 274

Scourge of Christendom, The, 17

Seb-Ergoud, 187

Sedan, 240

Selene, 25

Senatus-Consult, 253

Senegal, 68

Senegalese Algeria, I 55

Senoussiya, formula of, 66

" Sentinel of the Straits," 28 I

Septimus-Severus, 25

Service des Monuments His. toriques, 46

Sevilla, 89

Seybouse, plain of, 164

Sfax, 265, 275

Shah, Ismail, 62

Sheikh-el-Senoussi, the, 64

Sheikh-el-Tiga, 65

Sheikh Jamal-ed-Din, 80 Mohammed Abdou, 7 I Soltan, the, 227
Shiah sectarians, 6I

Shiaism, 63

Shintoism rites, 63

Si Abd-el-Aziz ben Masraly, 235

Si Abd-el-Kader ben el-Hadj Said, 230

Si Ahmed ben Lalali, 227

Si Ahmed ben Mohammed el Tidjani, 64

Sicily, 91, 244, 268

Sidi Ahmed-el-Mokrani, 27

Amrane, 235

Sidi-Bou-Medine, 14, 90, 98, 100, IOI

Sidi-Bou-Said, 274

Sidi-el-Khebir, 19

Sidi Fenuch, II 7

- Krelil, 226

- Mahdi-el-din, 120

- Okba, 25, 240, 276

- Rachid, 234, 235

Yada, 236

Sidon, 40

Sierra Leone, 297

Nevada, 5

Si-Hamza, I 35

Siki Okba ben Nafa, 219

Si Mohammed ben Ali el Senoussi, 60

Si Mohammed ben Mahommed el-Aid, 230, 233

Sinan Pasha, 106

Smalah, the, 123

Snitra, the, 87

Socielté Agricole du Sud-Algérien, 237, 238, 239

- Asiatique, 127 du sud-Algérien, 236

Sociétés Indigènes de l'rézoyance, 213

Solomon the eunuch, 56, 57

Songhais, 67

Song of K'oland, 85

Soudan, the, 298

Souk-el-Attarin, 271

Souk-el-Trok, 270

Sousse, 275

South Africa, 206

African farmer, 180

Spahis, 240 
Spain, 17, 75, 89, 91, 108, 176, $248,249,284,285,286,287$, 297

Spaniards, the, 23, 247, 248, 249, $250,256,257,268$

Speratus, 274

Staouelli, Monastery at, I66

Stoza, 57

Sufi dynasty, 63

- philosopher, the, 65

Suleyman, I IO

Sunna, 60

Sunni sectarians, 61

Sweden, 197

Switzerland, 166

Syed Ameer Ali, 76, 77, 78, 80

Syphax, 2I

Syria, 6I, 9r

Tagdempt, 122

Taguin, 123

Tagus, the, 54

Tamelhat, 230, 232

Tamerna, 235

Tangier, 282

Tanit, ro

Taourirt-Amokrane, 30

Targui, $23 \mathrm{r}$

Taza, 122

Tazmalt, 34

Tchad, Lake, 210, 297, 299

Tebessa, 57, 122

Tell, 20, 21, 36, 38, I 30, 140, 14 I, 157, 161, 162, 168, 173, 183, $185,216,224,243,250,251$, 259

Temacine, 230, 233

Temple of Asculapius, 273

Territoires Militaires du sud, 135

Tertullian, 47, 72

Thamugadi, $44,45,46$

The Barbary Corsairs, 107

The Broad Stone of Empire, 293

Theodosius, 50

The Spirit of Islam, 76

The Thousand and one Nights, 84

Tholbas, the Kabyle, 37

Thysdrus, 275
Tibeste (see Tebessa)

Tidikelt, 23 I

Tidjania, 67

Tilrempt, 39

"Time of Ignorance," 87

Timgad, 41, 43

Tipaza, 53, 54, 55

Titeri, I18, I2I

- Beylick of, $12 \mathrm{r}$

Tizi-ouzou, 23, 24

Tlemcen, 13, 20, 26, 84, 90, 98, 99, 100, I $21,122,126,139$

Togo, 297

Toledo, 97

'Touaregs, 33, 231, 235, 298

Touat, 23I

Touggourt, 220, 222, 228, 229, 230, 232, 234, 240, 24 I

Trajan's Gate, 45

Trastevere, 15

Treasury of the Directoire, I 16

Treaty of La Marsa, 262

Treaty of Tafna, 99, I2I

Tripoli, 25, 64, 65, 206, 21 7, 225, $263,269,277$

Troubadours, the, II 3

Tunis, 103, 161, 176, 267, 270, 27 I, 273

Tunisia, 102, I48, I 50, I 57, 210 , $238,244,263,264,265,268$, $269,274,275,277,278,279$, 301

Turkish women, 73

Turks, the, $26,63,65,70$, IOI, I I I, I I 9, I 30, I 56, 263

Tuscany, 244

Tyre, 40

Ulemas, 63, 64, 66, 67

United Kingdom, 166, 197, 207

Utah, I 74

Vada, Cape, 56

Valencia, I 5

Valentinian, 50

Vallée, Commandant, 122

Vandals, the, 21, 24, 25, 51, 56, $57,58,76$

Venice, 91, 102

Vernet, Horace, 123 
Versailles, 123

Victor, 53, 54

Victoria, Queen, 136

Voirol, General, 119

Voltaire, 85

Waddington, M., 284

Wahabis, 64

Wellington, Duke of, 125

Western Africa, 67

Empire, the, 63

White Fathers, 274
Women, unveiled, 23, 73

Yarmorasan of the Beni-Zeiyan, 99

Yemen, the, 64

Zanuiya, 64, 66, 233

Zeïta, 234

Zekkat, the, 146

Zeno, Emperor, 54

Zibans, mountains of the, 223

Zinder, 210 
Richard Clay \& Sons, Limited,

BRUNSWICK STRFET, STAMFORD STREET, S.E. AND BUNGAY SUFFOLK. 


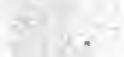$$
\text { y }
$$$$
1
$$$$
\text { , }
$$$$
\text { 更 }
$$ 

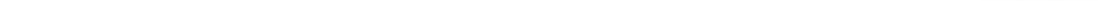


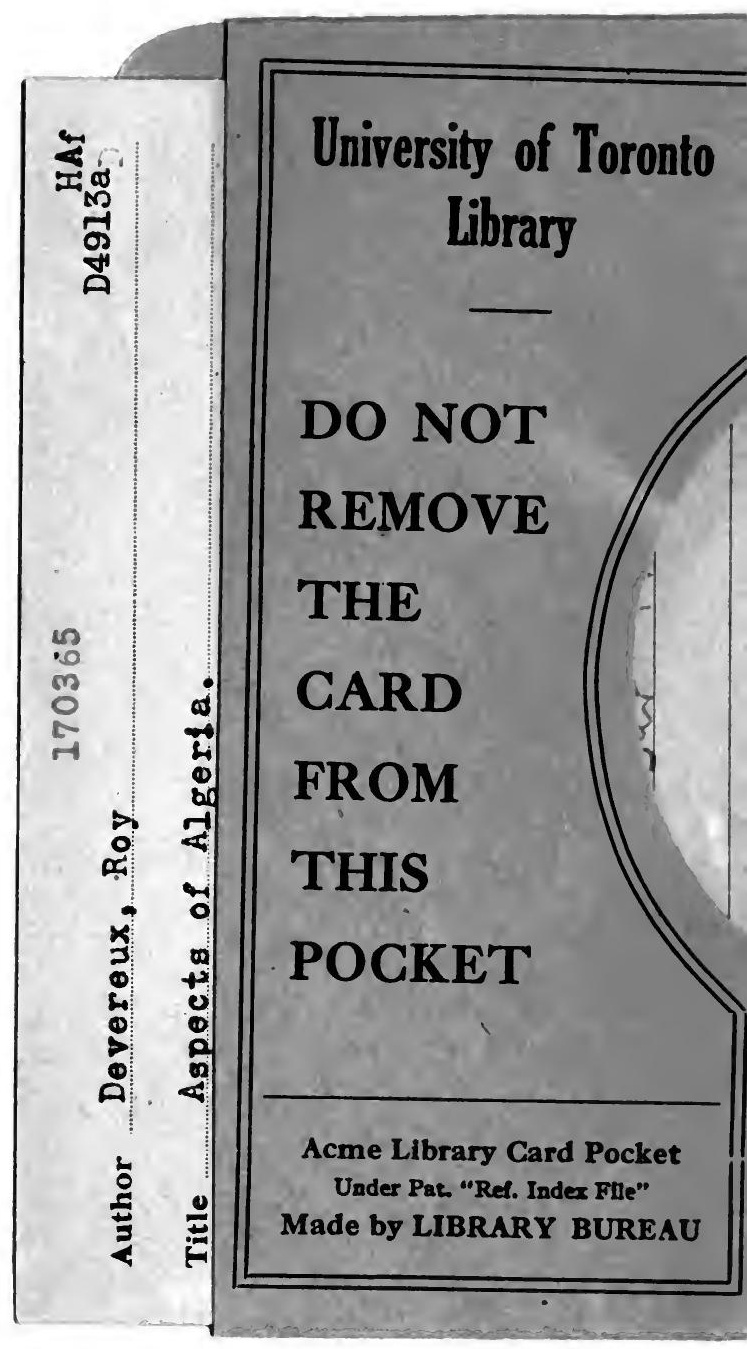


